\title{
Metodologia para Integração de Novas Tecnologias na Formação de Professores
}

Mônica Giacomassi de Menezes de Magalhães

Tese apresentada ao Instituto de Física de São Carlos, da Universidade de São Paulo, para obtenção do título de doutor em Ciências: Física Aplicada - subárea: Física Computacional.

Orientador: Prof. Dr. Dietrich Schiel

\section{SÃO CARLOS \\ 2004}


Magalhães, Mônica Giacomassi de Menezes de

Metodologia para Integração de Novas Tecnologias na Formação de Professores / Mônica Giacomassi de Menezes de Magalhães. São Carlos, 2004.

$148 \mathrm{p}$.

Tese (Doutorado) - Instituto de Física de São Carlos, 2004.

Orientador: Prof. Dr. Dietrich Schiel

1. Formação de Professores. 2. Novas Tecnologias na Educação

3. Integração de Tecnologias. 4. Multimídia Educacional. 
Ao amor da minha vida, Luís Eduardo (Dudu) e ao fruto do nosso amor e razão do nosso viver, João Vitor. 


\section{Agradecimentos}

Aos meus pais Eunice e Kerches por todo o amor e por tudo o que fizeram e fazem por mim; à minha irmã querida, Maria Fernanda pelo carinho e compreensão.

Ao Prof. Dr. Dietrich Schiel, pela orientação, dedicação e, acima de tudo, pela amizade que se fortaleceu no decorrer deste trabalho.

Ao amigo, Prof. Sérgio Luis Antonello, pelo incentivo, pela amizade sincera e por toda a ajuda no desenvolvimento deste trabalho.

À Profa. Iria Müller Guerrini, pelo carinho e amizade.

Ao Prof. Dr. Januário Sylvio Pezzotti, pela atenção e revisão.

À Profa. Dra. Maria da Graça Nicoletti Mizukami e à Profa. Dra. Edna Maura Zuffi, pelas valiosas contribuições.

Ao Prof. Marco Aurélio P. Souza e aos profissionais da Escola Estadual Conde do Pinhal de São Carlos, pela disposição na aplicação deste trabalho.

Às secretárias do CDCC/USP, Edna R. O. Ferreira e Miriam B. G. Magalhães, pela dedicação e amizade.

Aos funcionários do CDCC/USP, principalmente, Godoy, Otávio, Braz e Júnior, pelo apoio técnico oferecido.

Às funcionárias da Biblioteca do CDCC/USP, por toda a atenção.

À Wladerez A. G. Caiado, por sua dedicação a todos da Pós-Graduação.

Às funcionárias da Biblioteca do IFSC/USP, em especial, Cristina, Mara, Neusa e Betania, pela valiosa assistência.

Aos ex-supervisores do CEAPLA/UNESP, Prof. Dr. Gilberto José Garcia e Profa. Dra. Maria Juraci Zani dos Santos e ao atual supervisor Prof. Dr. Norberto Morales, pelo apoio, confiança e amizade.

À Ângela Locatelli, Rafael Scapin e aos amigos do CEAPLA/UNESP, pelos dias de descontração e alegria.

À minha tia, Leni Giacomassi, pelo incentivo constante.

À toda minha família, com muito amor.

Agradeço a Deus por tudo o que aconteceu em minha vida e a Nossa Senhora por guiar os meus passos, principalmente durante a gravidez, e depois me orientando no convívio familiar e no trabalho. 


\title{
Sumário
}

\author{
Lista de Figuras
}

Lista de Abreviaturas

Resumo

Abstract

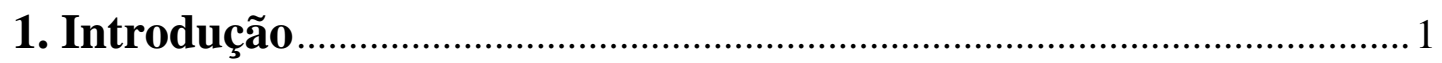

2. Novas Tecnologias Aplicadas ao Ambiente Educacional .................... 6

2.1 Considerações Gerais ............................................................................... 6

2.2 O Papel do Professor diante das Novas Tecnologias .................................. 9

2.2.1 Fatores que Influenciam o Uso de Novas Tecnologias pelos

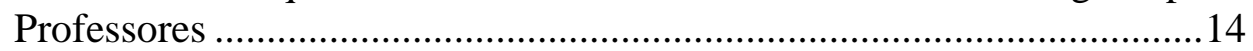

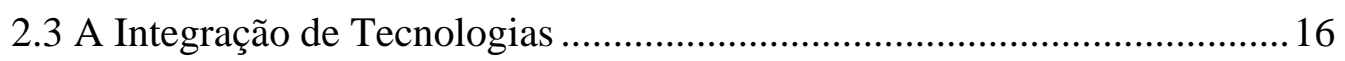

2.4 Exemplos de Aplicação de Tecnologias em Sala de Aula...........................20

2.5 Considerações Finais ................................................................................28

3. A Formação de Professores e as Novas Tecnologias ...........................29

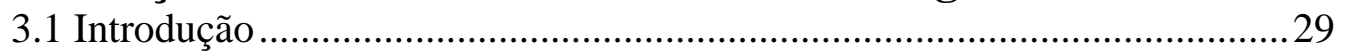

3.2 Formação de Professores: Considerações Gerais .......................................229

3.2.1 Formação Inicial de Professores...................................................34

3.2.2 A Tecnologia na Formação de Professores .......................................34

3.3 Aprendizagem da Docência: O Modelo de Shulman .................................37

3.4 Exemplos de Aplicação de Tecnologias na Formação de Professores ....... 42

3.5 Considerações Finais ............................................................................48

4. A Metodologia Proposta.........................................................................

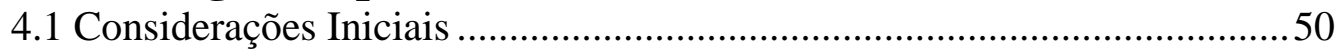

4.2 Fases da Metodologia Proposta ................................................................. 52

4.2.1 Fase de Preparação ......................................................................56

4.2.2 Fase de Produção ...........................................................................59

4.2.3 Fase de Integração ...................................................................62

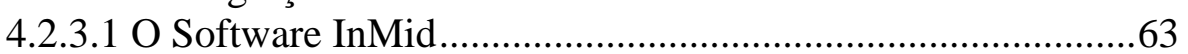

4.2.4 Fase de Visualização/Distribuição................................................70

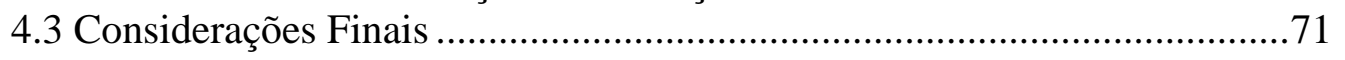

5. Aplicação e Avaliação de Novas Tecnologias e da Metodologia Proposta na Formação Inicial de Professores..........................................73

5.1 Considerações Iniciais: O Objeto da Pesquisa .........................................73 
5.1.1 O Curso de Licenciatura em Ciências Exatas da USP/São Carlos ...74

5.2 Aplicação de Tecnologias: Usando as Ferramentas Separadamente...........75

5.2.1 Utilização do Software SAM na Sala de Aula .................................76

5.2.2 Utilização das Tecnologias Mimio, Foto, Vídeo e Áudio na Sala de

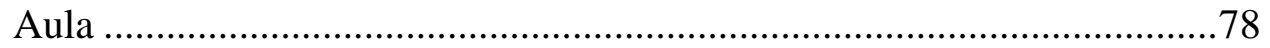

5.3 Aplicação da Metodologia: Integrando as Mídias ...................................... 82

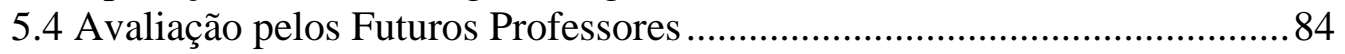

5.4.1 Resultados da Avaliação.............................................................85

5.4.2 Discussão dos Resultados............................................................92

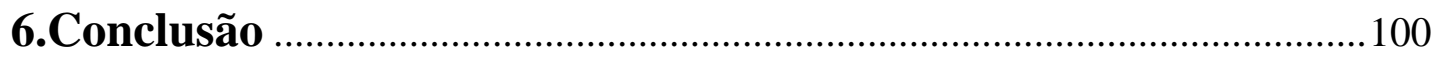

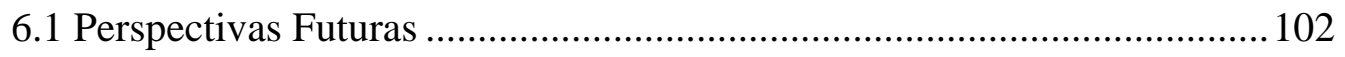

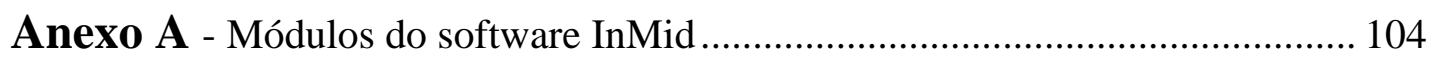

Anexo B - Materiais educacionais produzidos pelos futuros professores ............ 113

Anexo C - Primeira aplicação em escola pública................................................. 127

Anexo D - Exercícios da atividade-reflexão ..................................................... 129

Anexo E - Questionários aplicados com os futuros professores ........................ 131

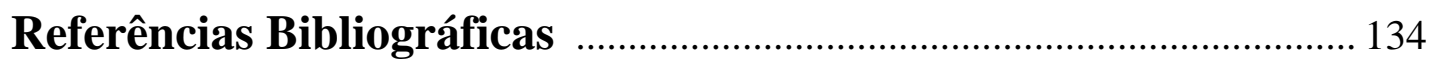

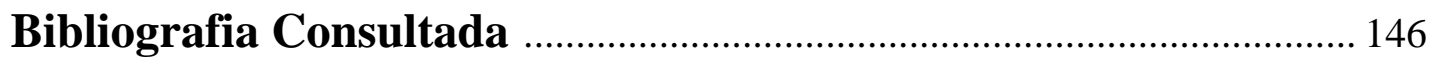

Apêndice I - O Mimio

Apêndice II - A Linguagem SMIL 


\section{Lista de Figuras}

Figura 1 - Infra-estrutura do Lectures on Demand.

Figura 2 - Material multimídia de um curso virtual da Universidade da Flórida no ambiente WebCT.

Figura 3 - Hiperdocumento gerado automaticamente pelo eClass. .25

Figura 4 - Interface de apresentação SMIL da informação de uma sessão capturada. .26

Figura 5 - Exemplo de uma palestra virtual desenvolvida pela equipe de EAD da UNICAMP. .27

Figura 6 - Fases da metodologia para integração de novas tecnologias na formação de professores. .53

Figura 7 - Módulo de Seleção de Mídias do software InMid 1.0. .66

Figura 8 - Fluxo de tarefas do InMid. .67

Figura 9 - Exemplo de um material multimídia produzido pelo professor com o InMid. .68

Figura 10 - Exemplo de um material multimídia produzido pelo professor com o InMid.

Figura 11 - Exemplo de um material multimídia produzido pelo professor com o InMid.

Figura 12 - Visualização do material multimídia no Browser Microsoft Internet Explorer. . .70

Figura 13 - Movimento de uma tartaruga. .77

Figura 14 - Movimento de uma bola de ping-pong................................................77

Figura 15 - Exemplo de tabela e gráficos sobre o movimento de uma tartaruga........78

Figura 16 - Informações da aula-exemplo de um futuro professor capturadas e exibidas no software do Mimio.

Figura 17 - Aula-exemplo utilizando o Mimio e sendo filmada por outro futuro professor. .80

Figura 18 - Exemplo de um trabalho final com links para várias mídias obtidas durante a aula. .81 
Figura 19 - Vídeo do movimento de uma caixa de leite na esteira do caixa de um supermercado.

Figura 20 - Informações capturadas da lousa com falhas de escrita. .87

Figura 21 - Informações capturadas da lousa sem falhas de escrita. .87

Figura 22 - Avaliação do software InMid pelos futuros professores, utilizando a Escala Likert .90

Figura 23 - Módulo de Seleção de Mídias. 105

Figura 24 - Módulo de Edição de Itens de Menu (Links para a Internet). 107

Figura 25 - Módulo de Edição de Texto de Menu, opção Texto Animado. 108

Figura 26 - Módulo de Inserção de Figuras. 109

Figura 27 - Módulo de Edição de Texto. 110

Figura 28 - Exemplo de documento SMIL gerado pelo InMid... 111

Figura 29 - Exemplo de arquivo RP gerado pelo InMid. 111

Figura 30 - Exemplo de arquivo RT gerado pelo InMid. 112

Figura 31 - Exemplo de documento HTML gerado pelo InMid. 112 


\section{Lista de Tabela}

Tabela I -Suporte teórico oferecido pela teoria de Rieber e Welliver (1989) e pelo modelo de Shulman (1987) para a metodologia proposta. ..... .54 


\section{Lista de Abreviaturas}

ALN - Asynchronous Learning Network

ANPEd - Associação Nacional de Pós-Graduação e Pesquisa em Educação

AVI - Audio Video Interleave

BMP - BitMap Picture

CAPES - Coordenação de Aperfeiçoamento de Pessoal de Nível Superior

CCUEC - Centro de Computação da UNICAMP

CDCC - Centro de Divulgação Científica e Cultural

EAD - Educação à Distância

eClass - Electronic Classroom

E-learning - electronic learning ou aprendizagem eletrônica

E-mail - Electronic Mail ou correio eletrônico

EMF - Enhanced Windows Metafile

GPL - General Public License

HTML - HyperText Markup Language

ICMC - Instituto de Ciências Matemáticas e de Computação

IEEE - Institute of Electrical and Electronics Engineers

IFSC - Instituto de Física de São Carlos

IMS - Instructional Management Systems

InMid - Software para Integração Sincronizada de Mídias

IQSC - Instituto de Química de São Carlos

JPG (JPEG) - Joint Photographic Experts Group

LTSC - Learning Technology Standards Committee

MBC - Mimio BoardCast file

MEC - Ministério de Educação e Cultura

MPEG - Moving Picture Experts Group

PDA - Personal Digital Assistant

ProInfo - Programa Nacional de Informática na Educação

RIVED - Rede Internacional Virtual de Educação

RM - RealMedia 
RP - RealPicture

RT - RealText

SAM - Software para Análise de Movimentos

SEED - Secretaria de Educação à Distância

SEMTEC - Secretaria de Educação Média e Tecnológica

SMIL - Synchronized Multimedia Integration Language

SWF - ShockWave File

UNICAMP - Universidade Estadual de Campinas

URL - Uniform Resource Locator

USB - Universal Serial Bus

USP - Universidade de São Paulo

XHTML - Extensible Hypertext Markup Language

XML - Extensible Markup Language

XSLT - Extensible Stylesheet Language Transformation

W3C - World Wide Web Consortium

Web ou WWW - World-Wide Web

WMF - Windows Metafile Format 


\section{Resumo}

O presente trabalho consiste no desenvolvimento, implantação e avaliação de uma metodologia para auxiliar o professor no uso de novas tecnologias em suas aulas, orientando-o na integração de informações para a produção do próprio material educacional multimídia. Pesquisou-se o uso de tecnologias em sala de aula e na formação de professores, com o objetivo de apresentar uma visão geral do que tem sido feito na área. Realizou-se ainda, um levantamento de propostas de autores sobre a formação do professor mostrando-se a importância do uso da tecnologia em sua formação inicial, no seu modo de ensinar e da aprendizagem da docência. A metodologia proposta constitui-se de quatro fases: Preparação, Produção, Integração e Visualização/Distribuição. Para ser utilizado, na fase de Integração, foi desenvolvido o software InMid, cujo objetivo é permitir que o professor integre diversas mídias obtidas antes, durante e/ou após a aula, possibilitando a sincronização das mesmas. A metodologia e o InMid foram aplicados no curso de Licenciatura em Ciências Exatas da USP/São Carlos, onde realizou-se uma avaliação, para que os futuros professores pudessem expressar dificuldades e facilidades encontradas com a utilização dos mesmos. 


\section{Abstract}

The present work consists on development, implementation and evaluation of a methodology to aid teachers using technology in classroom and integrating information for the production of their own educational multimedia material. Technology applications in classroom and in the initial teacher education were researched. Proposals about the teacher education were still presented. The importance of the technology in the initial teacher education, the importance of how the teacher teaches and the importance of the teacher learning were showed. The methodology was constituted by four phases: Preparation, Production, Integration and Visualization/Delivery. The software InMid was developed to be used in the phase of Integration and its objective is to allow the teacher to integrate several medias obtained before, during and after the class, facilitating the synchronization of them. The methodology and the InMid were applied in an initial teacher education course of the USP/São Carlos and they were evaluated to know about the future teachers' difficulties and facilitates in using them. 


\section{Introdução}

Certos ambientes computacionais propõem o fornecimento de uma variedade de serviços utilizando novas tecnologias. Um desses serviços é capturar experiências diárias de alunos e professores, em sala de aula, e transformá-las em informações disponíveis para uso posterior. Essas experiências, integradas com novas tecnologias e possibilitando a produção de material educacional multimídia, proporcionam uma inovação no processo de ensino/aprendizagem nas escolas brasileiras.

Em uma perspectiva de ensino/aprendizagem, o desafio para os acadêmicos é saber como utilizar as novas tecnologias de informação e de comunicação, de uma maneira pedagogicamente apropriada, de acordo com as necessidades de seus alunos e no contexto educacional (Asensio, et al., 2001).

Educar com novas tecnologias é um desafio, que até agora, não foi enfrentado com profundidade (Moran, 2002). Egbert, et al. (2002) salientam a necessidade da realização de estudos de como os professores adquirem conhecimento pedagógico do conteúdo, dentre outros. Também salientam a necessidade de investigação das teorias de aprendizagem com transferência de tecnologias do curso de formação de professores para a sala de aula e como isso é evidenciado pelas aplicações que os professores empregam. Portanto, é preciso, primeiramente, uma familiarização do professor com as novas tecnologias. Para que isso ocorra, as atividades de treinamento e aproximação entre professores e tecnologias devem ser 
realizadas, de preferência, nas licenciaturas (formação inicial de professores) (Kenski, 2003).

No Brasil, André (2000) realizou uma pesquisa em 410 teses e dissertações dos Programas de Pós-Graduação em Educação, defendidas no período de 1990 a 1998, que se encontravam sob o descritor “formação de professores”. Para o levantamento dos dados, a autora utilizou como referência o CD-ROM da Associação Nacional de Pós-Graduação e Pesquisa em Educação (ANPEd), $3^{\text {a }}$ edição, lançado em setembro de 1999, que contém os resumos dos trabalhos citados acima. Essa pesquisa revelou que, nos trabalhos sobre Licenciatura, quase não houve questões relacionadas às novas tecnologias, materiais de ensino e meios de comunicação.

\footnotetext{
"Resumindo os aspectos investigados nos trabalhos sobre Licenciatura, nota-se que a grande maioria estuda o funcionamento do curso, seja em termos das disciplinas pedagógicas e específicas (42,5\%), seja em termos do currículo como um todo (24\%). A atuação do professor também é um aspecto razoavelmente investigado (15\%) enquanto que o aluno da licenciatura recebe pouca atenção nos trabalhos (apenas quatro estudos). Questões relacionadas às novas tecnologias, materiais de ensino e meios de comunicação são quase esquecidas” (André, 2000, p.88).
}

Outra pesquisa, realizada por Ramalho, et al. (2002), procurou revelar o que vem sendo pesquisado nos Programas de Pós-Graduação em Educação sobre o professor e sobre a sua formação. Para isso, tomou-se como base o ano 2000, utilizando-se como fonte de informação o CD-ROM Coleta da Coordenação de Aperfeiçoamento de Pessoal de Nível Superior (CAPES) dos Programas de PósGraduação em Educação. A pesquisa também revelou que em estudos sobre formação inicial de professores não houve questões sobre novas tecnologias.

A título de contribuição com a formação de professores no uso de novas tecnologias, este trabalho propõe o desenvolvimento, a implantação e a avaliação, em um curso de Licenciatura, de uma metodologia para orientar o professor na incorporação de novas tecnologias em sala de aula, fornecendo conhecimentos necessários para explorar os seus recursos e fazendo com que o mesmo consiga 
produzir o próprio material educacional digital, de maneira a auxiliá-lo na adaptação das suas necessidades pedagógicas à linguagem multimídia. Também foi feita uma breve revisão de pesquisas no uso de tecnologias em sala de aula e na formação de professores com o objetivo de apresentar uma visão geral do que tem sido feito na área. Foi realizado um levantamento de propostas de autores sobre a formação de professores, além do desenvolvimento de uma ferramenta para a integração de mídias, de uma forma simples, para ser realizada pelo próprio professor. Acredita-se, ainda, que a metodologia proposta sirva como base para projetos futuros, pois as informações integradas estarão disponíveis para eventuais sistemas. Este trabalho também pode facilitar o posterior oferecimento de cursos à distância, utilizando o material multimídia, produzido pelos professores, em um ambiente virtual já existente. Seus objetivos específicos são:

a) Investigar tecnologias para a implantação e utilização como recurso pedagógico em sala de aula;

b) Identificar as necessidades de futuros professores na utilização de tecnologias em sala de aula através de uma aplicação e avaliação na formação inicial de professores;

c) Investigar a aplicação de tecnologias na formação de professores;

d) Levantar a opinião dos futuros professores, enquanto alunos ${ }^{1}$, a respeito do uso de tecnologias;

e) Desenvolver uma metodologia para que o professor possa orientar-se no uso de diversas tecnologias em sala de aula e na produção de material educacional multimídia, apresentando as informações de maneira integrada e sincronizada.

f) Implantar a metodologia proposta em um curso de formação inicial de professores.

g) Avaliar e discutir os resultados.

Neste trabalho, a estratégia de investigação adotada foi a qualitativa e as técnicas de coletas de dados foram a observação em sala de aula e questionários com questões dissertativas e alguns testes (questões fechadas) com atribuição de escala

\footnotetext{
${ }^{1}$ Durante a sua formação e a partir da proposta metodológica deste trabalho, o futuro professor terá oportunidade de analisar o uso de tecnologias não apenas no processo de ensino, como professor, mas também na aprendizagem, como aluno.
} 
quanto à satisfação do usuário. As questões foram elaboradas de forma a entender o processo que os futuros professores vivenciaram, primeiramente com o uso de novas tecnologias em suas aulas e, depois, na integração de mídias para fins pedagógicos.

Uma das fontes teóricas para a análise dos dados foi o modelo de Shulman (1987) sobre o conhecimento e o raciocínio do professor e sobre a aquisição de conhecimento como parte importante para a melhoria da qualidade da prática docente e sua didática. O modelo desenvolvido por Shulman tem servido de exemplo em muitos países do mundo (Mendes, 2003). Como neste trabalho se sugere que o futuro professor utilize tecnologias para o ensino, escolheu-se o modelo de Shulman, por tratar a aprendizagem da docência e a forma como o conteúdo é apresentado aos alunos, podendo utilizar, para isso, algum recurso tecnológico. Este modelo também serviu como referencial teórico no desenvolvimento da metodologia aqui proposta, bem como a teoria hierárquica de integração de tecnologias de Rieber e Welliver (1989).

Várias questões foram levantadas no início deste trabalho: Como auxiliar o professor na utilização de diversas tecnologias em sala de aula? Como aplicar novas tecnologias na sala de aula convencional sem a necessidade de uma infraestrutura avançada? Como utilizar as novas tecnologias em sala de aula para produzir material educacional? De que forma os professores podem integrar as informações obtidas sem que possuam amplos conhecimentos de linguagem computacional? Como os futuros professores aprendem a dar aula utilizando novas tecnologias?

Ao final da coleta de dados, observou-se que a pesquisa não se focava nesta última questão, pois havia um interesse maior em analisar como a metodologia proposta para a integração de mídias contribuiu para que os futuros professores pudessem usar novas tecnologias em suas aulas.

Assim, as novas perguntas a serem respondidas foram: As tecnologias podem ser incorporadas em sala de aula sem a necessidade de uma infra-estrutura avançada? Informações obtidas antes, durante e após a aula podem ser integradas pelos próprios professores, de forma que seja produzido material educacional digital? Os professores aprendem com o uso da tecnologia?

Em experiência com alunos do curso de Licenciatura em Ciências Exatas da Universidade de São Paulo (USP), campus de São Carlos (futuros professores), buscou-se definir e testar as possibilidades de uso de tecnologias e levantar requisitos 
para o desenvolvimento da metodologia para integração de novas tecnologias em sala de aula, analisando a utilização, não somente de computadores e da Internet, mas de outros conhecimentos científicos como softwares educacionais, vídeo, áudio e Mimio $^{2}$.

Nesta experiência, verificou-se a possibilidade de integrar as informações capturadas de várias fontes de mídias durante a aula, utilizando apenas conhecimentos básicos de informática e não havendo a necessidade de usar uma infra-estrutura mais avançada para isso (como, por exemplo, servidor de vídeo). Identificada a possibilidade de integração, iniciou-se uma investigação de softwares que poderiam fazer esse tipo de atividade sem gastos para o professor ou para a escola. Com esse estudo de softwares e com as possibilidades identificadas, decidiuse pelo desenvolvimento de um software para Integração Sincronizada de Mídias, denominado InMid.

A proposta metodológica deste trabalho, partiu de preocupações educacionais da autora, que tem como formação a computação e considera que é possível aplicar ferramentas computacionais e outras tecnologias para a melhoria do processo pedagógico.

Este trabalho está dividido em seis capítulos, sendo este o capítulo introdutório. No Capítulo 2 encontram-se informações quanto à utilização de novas tecnologias no ambiente educacional, uma breve descrição de algumas tecnologias aplicadas ao ensino, informações do professor diante das novas tecnologias, fatores que influenciam o seu uso e uma breve revisão da literatura sobre o uso de tecnologias em sala de aula. O Capítulo 3 é dedicado à formação de professores, ao modelo de Shulman e também fornece uma breve revisão da literatura sobre o uso de tecnologias na formação de professores. No Capítulo 4 é apresentada a proposta de uma metodologia para integração de novas tecnologias na formação de professores, suas fases e o desenvolvimento do software InMid, utilizado na fase de Integração. No Capítulo 5 são apresentadas a aplicação e a avaliação de tecnologias no curso de Licenciatura em Ciências Exatas da USP/São Carlos e da metodologia proposta. O Capítulo 6 apresenta a conclusão do trabalho, assim como as perspectivas futuras.

\footnotetext{
${ }^{2}$ Ver Apêndice I, para maiores informações sobre o Mimio.
} 


\section{Novas Tecnologias Aplicadas ao Ambiente Educacional}

\subsection{Considerações Gerais}

A introdução de tecnologias de informação e de comunicação em ambientes educacionais é uma realidade inquestionável no cotidiano das escolas e de fundamental importância, favorecendo a renovação das técnicas de aprendizagem e fornecendo novos desafios para os professores, permitindo reativar-lhes o papel de agentes fundamentais da mudança.

A utilização da tecnologia no processo de ensino/aprendizagem tem mudado a educação nos últimos tempos. Atualmente, professores e alunos estão interagindo, não apenas em aulas presenciais, mas também, em cursos à distância, via Internet. Os alunos estão participando de aulas em suas residências; os professores estão armazenando materiais didáticos para disponibilizar aos seus alunos; as Instituições de Ensino estão utilizando tecnologias de áudio e vídeo, via Internet, para ajudar os professores a maximizar suas habilidades, a fim de melhorar a aprendizagem dos seus alunos. Com isto, pode-se dizer que está ocorrendo uma revolução na Educação, uma nova era no processo de ensino/aprendizagem.

A evolução da tecnologia de informação e de comunicação está 
revolucionando as práticas e estruturas do ambiente de ensino. Em trabalho anterior (Magalhães, 1997), constatou-se que as tecnologias da era da informação têm o potencial de contribuir para o aluno ter mais responsabilidade com sua aprendizagem independente.

De acordo com Asensio e Young (2002), no último século tem havido uma sucessão de tecnologias que proporcionam visualizar imagens em movimento, tais como, filme, televisão, videocassete, vídeo digital, multimídia, CD-ROM, TV interativa e, agora, mídia baseada na World Wide Web (WWW ou Web) (BernersLee, et al., 1994), sendo que todas essas tecnologias foram desenvolvidas, primeiramente, para o setor de entretenimento e, posteriormente, utilizadas no ambiente educacional. A característica em comum de todas essas tecnologias é a capacidade de mostrar imagens aos alunos.

Os autores afirmam que, a partir da década de 80 até a metade dos anos 90, o videocassete, o vídeo digital e a multimídia tornaram realidade a promessa de interatividade, sendo a imagem ainda importante, mas com a idéia de que o usuário possa ter um acesso mais fácil e controlável. Na metade da década de 90, a Web reforçou a idéia de acessibilidade e interatividade, adicionando um novo elemento - a integração.

O termo “interatividade” é recente e emerge juntamente com a ampliação da informática e das novas tecnologias da informação e comunicação (Schechtman, 2001 apud Antonello, 2003). Para Romiszowski e Mason (1996), a interatividade é a capacidade dos participantes receberem “feedback" como contribuição de algum outro membro do processo de comunicação. Nos meios educacionais, o termo interatividade descreve as formas de comunicação que possibilitam um diálogo entre o professor e o aluno (Jonassen, 1994), e é uma importante característica de ambientes educacionais que utilizam alguma forma de tecnologia. A interatividade entre o usuário e o ambiente educacional deve ser um objetivo importante no projeto de programas de suporte à aprendizagem (Shephard, 2002).

Já a integração pode ser obtida por meio do uso de diversas mídias integradas em um único material educacional, ou seja, através do uso de material multimídia. Com a utilização de conexões de alta velocidade na Internet, os usuários podem recuperar informação no formato multimídia mais facilmente, incluindo áudio e, particularmente, vídeo. O vídeo é uma tecnologia que está se tornando muito 
popular na educação, por enriquecer o conteúdo e combinar-se com áudio e informação textual.

A criação e o uso de vídeo baseado na Web tornaram-se acessíveis aos educadores e alunos, possuindo um potencial de transformarem-se em componentes de rotina na Educação à Distância (EAD). Apesar da utilização do vídeo convencional já ter uma longa história na educação, sempre foi limitada pelo alto custo de produção e dificuldades de distribuição. Entretanto, os custos de produção têm caído com a emergência de câmeras de fácil manuseio e de alta qualidade, e de softwares de edição de vídeo para uso doméstico e de fácil acesso aos usuários. A distribuição de vídeo tem sido revolucionada pelo crescimento da Web como um meio educacional.

Em contraste aos avanços tecnológicos, a pesquisa no uso pedagógico do vídeo na Web tem sido pouco revisada (Asensio, et al., 2001). O impacto da combinação da integração de elementos multimídia e aplicações de rede no ambiente educacional ainda precisa ser explorado e avaliado (Asensio e Young, 2002).

Apesar do destaque do uso do vídeo na Web, ainda há escolas públicas no Brasil com problemas de conexão com a Internet (Magalhães e Schiel, 2000; Schiel, et al., 2000; Souza, 2000; Schiel, et al., 2002a; Guerrini e Castro, 2003). Para favorecer a inclusão digital das pessoas ligadas a essas escolas, pode ser utilizada a multimídia, também em um computador local, sem a necessidade de estar conectado à Internet.

A seguir serão descritas, brevemente, algumas tecnologias disponíveis para uso na educação, tais como: Vídeo, Televisão, Web, Videoconferência, Lousa Eletrônica e Mimio.

- Vídeo: Algumas características sobre o uso do vídeo na educação, descritas por Landim (1997) são: o aluno tem controle sobre o tempo do que está gravado; permite sua repetição; maior interação com materiais impressos e áudio dentro de um pacote multimídia; os custos da elaboração de um vídeo são agregados aos de duplicação e distribuição; a difusão por meio de canais de distribuição convencionais é dispendiosa, lenta e limitada.

- Televisão: Landim (1997) destaca algumas características do uso da televisão na educação: tecnologia linear, ou seja, não permite interrupção e está limitada a 
um horário de emissão, dificultando a utilização em momentos presenciais ou em aulas; a interação com outros materiais se limita às atividades prévias ou posteriores à exibição; há uma economia de custos de distribuição e duplicação e a difusão é massiva e imediata.

- Web: A Web é uma tecnologia que favorece o acesso a uma grande variedade de repositórios de materiais educacionais e sua utilização está se tornando uma norma para cursos fornecidos por muitas universidades. As vantagens da tecnologia Web aplicadas à educação, são: permitir escrita colaborativa; distribuir informação atualizada em larga escala; reduzir custos de distribuição; feedback dos alunos mais constante e com maior facilidade; favorecer a interatividade entre professores e alunos e entre alunos (Magalhães, 1997).

- Videoconferência: A Videoconferência permite que várias pessoas, em lugares diferentes, possam ver-se, comunicar-se, trabalhar juntas, trocar informações, aprender e ensinar. Possibilita uma interação face a face entre alunos e instrutores, fornecendo comunicações de vídeo e áudio.

- Lousa Eletrônica e Mimio: As tecnologias para captura de informações escritas em uma lousa, como a lousa eletrônica e o Mimio, possuem softwares próprios ou podem ser utilizadas em ambientes computacionais. Essas tecnologias capturam instantaneamente as anotações feitas pelo professor na lousa e as armazenam em arquivos.

\subsection{O Papel do Professor Diante das Novas Tecnologias}

A informática, aplicada a um processo educacional, consiste no uso da tecnologia para o desenvolvimento de atividades educativas, individuais ou coletivas, com o objetivo de ampliar as possibilidades de acesso e manipulação das informações, bem como o desenvolvimento e aprimoramento dos processos cognitivos através de softwares ou hardwares (Vermelho, et al., 1998). O aumento do uso da tecnologia na educação tem permitido a otimização dos recursos disponíveis, possibilitando multiplicar o acesso ao conhecimento (Moran, 1995). 
Num primeiro momento, as novas tecnologias são uma novidade que requerem adaptação em termos operacionais, sendo preciso que o professor aprenda a usar equipamentos, a trabalhar com programas e a assimilar conceitos e vocabulário próprio de uma nova área (Azevedo, 1999).

De acordo com Simião e Reali (2002), os novos cenários educacionais apontam a importância de desenvolver nos alunos maior agilidade de raciocínio mental e formal, capacidade de comunicação e expressão, autonomia e criatividade. Para os autores, as tecnologias deveriam constituir instrumentos facilitadores para a criação de ambientes de aprendizagem desafiadores e lúdicos, capazes de contribuir, também, para a construção do conhecimento de modo interdisciplinar.

A apreensão do conhecimento, na perspectiva das novas tecnologias, ao serem assumidas como uma possibilidade didática, exige que, em termos metodológicos, também se oriente a prática ${ }^{3}$ docente com base em uma nova lógica, visando a exploração de novos tipos de raciocínios (Kenski, 2003). É preciso que o professor não mais se posicione como o detentor do saber, mas sim como um parceiro encaminhando e orientando o aluno diante das múltiplas possibilidades e formas de alcançar o conhecimento e de se relacionar com ele (Kenski, 2003). O professor se transforma no estimulador da curiosidade do aluno por querer conhecer, por pesquisar, por buscar a informação mais relevante (Moran, 1995). De acordo com Simião e Reali (2002, p.129),

“o uso de computadores pode, de um lado, fornecer a ilusão de que a escola está em transformação ou, de outro, contribuir de forma mais significativa nos processos de aprender e ensinar. Essa última perspectiva demanda uma nova postura dos profissionais e, neste sentido, é preciso repensar os sistemas educacionais, tendo em mente questões relacionadas à formação de professores e ao papel do aluno frente a esses novos desafios.”

Tendo em vista esse cenário, Simião e Reali (2002) evidenciaram que a formação de professores passa por grandes desafios devido a mudanças em seu papel

\footnotetext{
${ }^{3}$ Neste caso, assumimos a definição de Pérez Gómez (1995), onde a prática é definida como a aplicação no contexto escolar das normas e técnicas derivadas do conhecimento científico.
} 
de instrutores e transmissores de conhecimento, para o de organizadores e orientadores da aprendizagem.

As características dessas novas formas de ensinar baseiam-se na consciência sobre as alterações nos papéis dos professores e das escolas no oferecimento de oportunidades de ensino; na ampliação das possibilidades de aprendizagem em outros espaços, não-escolares; na possibilidade de oferecimento de ensino de qualidade em espaços, tempos e lugares diferenciados (presenciais ou à distância); no oferecimento do ensino ao aluno, a qualquer momento e onde quer que ele esteja; no envolvimento de todos para a construção individual e coletiva dos conhecimentos (Kenski, 2003).

Segundo Moran (2002), os modelos de educação tradicional não servem mais, por isso é importante experimentar algo novo em cada semestre; fazer as experiências possíveis nas condições concretas; perguntar no começo de cada semestre: "O que estou fazendo de diferente neste curso? O que vou propor e avaliar de forma inovadora?” Assim, pouco a pouco, o professor vai avançando e mudando. Pode-se começar por formas de utilização das novas tecnologias mais simples e ir assumindo atividades mais complexas.

A reflexão sobre a adoção das novas tecnologias no processo de ensino envolve a preocupação com novas questões estruturais, como: Que tipo de aluno vai ter acesso a esses meios? Com que finalidade? Ensinar computação ou ensinar com o auxílio do computador? Que alterações curriculares acarretarão essas transformações? Que formação será necessária aos professores que vão atuar com os novos meios? (Kenski, 2003). As novas tecnologias orientam para o uso de uma proposta diferente de ensino; não se trata de adaptar as formas tradicionais aos novos equipamentos ou vice-versa. Primeiramente, é preciso definir que tipo de educação se deseja desenvolver e que tipo de aluno se pretende formar, sendo necessário identificar, dentre as tecnologias disponíveis, as que melhor se enquadram às propostas educativas da instituição de ensino (Kenski, 2003).

O professor possui uma variedade de opções metodológicas, de possibilidades de organizar sua comunicação com os alunos, de introduzir um tema, de trabalhar com os alunos, presencialmente e virtualmente, e de avaliá-los. Cada professor pode encontrar sua forma mais adequada de integrar as várias tecnologias e procedimentos metodológicos, mas também, é importante que aprenda a dominar as 
formas de comunicação, que encontre o meio que o ajude a sentir-se bem, a comunicar-se bem, a ensinar bem, a ajudar os alunos a aprender melhor. Para tanto, é importante diversificar as formas de dar aula, de realizar atividades, de avaliar (Moran, et al., 2000).

As tecnologias aplicadas na educação não devem ter por objetivo substituir o professor. O professor deve buscar conhecimentos nas mais diversas áreas para atingir seu objetivo que é o de ensinar e aprender; inclusive deve buscar meios para diversificar as formas de ensino. Cysneiros (2000) destaca que o professor não deverá explorar as novas tecnologias com ênfase na ferramenta, mas sim, no conteúdo.

O professor deverá firmar um novo compromisso com a pesquisa, com a elaboração própria, com o desenvolvimento da crítica e da criatividade, postura que deverá manter quando estiver trabalhando num ambiente informatizado (Demo, 1993 apud Vermelho, et al., 1998). Ele deve estar encorajado a aceitar suas responsabilidades de usuário e aprendiz da tecnologia (Galloway, 2001). No entanto, não se deve esperar que todos os professores de uma escola utilizem novas tecnologias em suas aulas (Cysneiros, 2000).

Kenski (2003) explica que é preciso que o professor tenha tempo e oportunidades de familiarização com as novas tecnologias, para conhecer as possibilidades e os limites das mesmas; para que, na prática, faça escolhas conscientes sobre o uso das formas mais adequadas ao ensino de um determinado tipo de conhecimento, para um grupo específico de alunos e no tempo disponível. Ou então, que o professor caminhe sua prática para uma abordagem que dispense totalmente a máquina, e os alunos aprendam até com mais satisfação. As atividades de narrativa oral e de escrita não estão descartadas. A diferença didática não está no uso ou não das novas tecnologias, mas na compreensão das suas possibilidades.

Laurillard (1995) (apud Kenski, 2003) apresenta os papéis do professor e do aluno em quatro tipos diferentes de ensino que podem ser desenvolvidos por meio dos diversos tipos de tecnologias:

1- No primeiro tipo de ensino, o professor se apresenta como o “contador de histórias” e pode ser utilizado, nesse caso, um vídeo, um programa de rádio ou uma teleconferência, por exemplo.

2- No segundo tipo, o professor assume o papel de negociador, e o 
ensino se dá por meio da “discussão” do conteúdo aprendido em outros tipos de interações fora da sala de aula, como por exemplo a leitura de um texto ou livro, a observação ou a visita a um determinado lugar ou assistir a um filme.

3- A terceira possibilidade exclui inclusive a ação direta do professor. Nesse caso, é o aluno que assume o papel de "pesquisador" e interage com o conhecimento por meio dos mais diferenciados recursos multimídia. O aluno aprende “por descoberta” e cabe ao professor a interação final com o aluno, para “ordenar” os conhecimentos por ele apreendidos nos outros espaços do saber.

4- A quarta modalidade de ensino é a que apresenta professores a alunos como “colaboradores”, utilizando os recursos multimídia em conjunto para realizarem buscas e trocas de informações, criando um novo espaço significativo de ensino/aprendizagem em que ambos (professor e aluno) aprendem.

O uso de tecnologias também modifica a rotina das escolas, pois são necessários alguns deslocamentos para aulas em laboratórios e uma reorganização da sala de aula, criando uma nova distribuição de espaço e uma nova relação de tempo entre o trabalho do professor com o aluno (Kenski, 2003). Por isso,

“aos professores é necessária uma reorganização da sua carga horária de trabalho, para incluir o tempo em que pesquisam as melhores formas interativas de desenvolver as atividades, fazendo uso dos recursos multimídia disponíveis; incluir um outro tempo para a discussão de novos caminhos e possibilidades de exploração desses recursos com os demais professores e os técnicos e para refletir sobre todos os encaminhamentos realizados, partilhar experiências e assumir a fragmentação das informações, como um momento didático significativo para a recriação e a emancipação dos saberes” (Kenski 2003, p. $51)$.

A autora conclui que as alterações nas estruturas e na lógica dos conhecimentos caracterizam-se como desafios para as instituições de ensino de todos 
os níveis e, sobretudo, requerem novas concepções para as abordagens disciplinares, novas metodologias e novas perspectivas para a ação docente.

\subsubsection{Fatores que Influenciam o Uso de Novas Tecnologias pelos Professores}

Estudos realizados em escolas e com professores que utilizam tecnologias (Muir-Herzig, 2004; Ribas, 2002; Dell'aglio, et al., 2002; Hadley e Sheingold, 1993 apud Albion e Gibson, 2000; Sherwood, 1993 apud Albion e Gibson, 2000; Office of Technology Assessment, 1995 apud Sandholtz, 2001) identificaram certos fatores que influenciam o uso das mesmas. Todos citaram a falta de conhecimento da tecnologia ou de treinamento e de tempo do professor. Alguns citaram problemas de acesso aos equipamentos e a falta de suporte.

O trabalho de Muir-Herzig (2004) conclui que as barreiras no uso de novas tecnologias, pelo professor, na educação, são: falta de tempo, altos custos e acesso limitado aos equipamentos, falta de conhecimento para usar a tecnologia, falta de suporte, avaliações que não refletem o que se aprende com a tecnologia, sendo que as maiores barreiras são a falta de treinamento e falta de prática no uso do computador e de outros equipamentos ${ }^{4}$.

Ribas (2002), em uma pesquisa realizada numa escola pública de Ensino Médio do interior do Paraná, apontou a falta de tempo e de conhecimento técnico dos professores para o uso da informática, como as principais barreiras para a incorporação de tecnologias no processo de construção do conhecimento.

O estudo de Dell'aglio, et al. (2002) investigou as percepções de professores quanto à utilização de novas tecnologias na educação superior. As desvantagens citadas nesse estudo foram relacionadas à falta de tempo e de treinamento, sendo que, em muitas situações, observou-se que o empecilho "falta de tempo" funcionou como uma defesa dos professores frente ao impacto ocasionado pela tecnologia e à sua conseqüente necessidade de adaptação.

\footnotetext{
${ }^{4}$ Estes problemas foram levados em consideração no desenvolvimento deste trabalho, como se verá no Capítulo 4.
} 
Estudos com a utilização de computadores por professores, nos EUA e Austrália (Hadley e Sheingold, 1993 apud Albion e Gibson, 2000; Sherwood, 1993 apud Albion e Gibson, 2000), também identificaram que as principais barreiras no uso do computador são: acesso limitado aos equipamentos, treinamento inadequado, falta de suporte e falta de tempo para preparar o material.

Pesquisa realizada pelo Office of Technology Assessment (1995) (apud Sandholtz, 2001), relata oportunidades e obstáculos de uso de novas tecnologias em escolas dos EUA. O relatório produzido cita as barreiras encontradas em muitas escolas, como o acesso limitado à tecnologia, a localização dos computadores, falta de suporte, falta de tempo para o professor realizar experiências e falta de oportunidades de conversar com outros professores sobre tecnologia. A pesquisa conclui que o maior obstáculo para a adoção de computadores nas escolas foi a falta de capacitação prévia dos professores para saber como utilizar essa nova ferramenta de trabalho, principalmente, como introduzir o uso do computador no currículo, e que a tarefa mais importante é a ajuda aos professores no uso eficaz de tecnologias.

Nessa perspectiva, Cysneiros (2000) comenta que o ideal é que o professor aprenda a lidar com as tecnologias durante sua formação regular em disciplinas ou, de modo mais detalhado, nas didáticas de conteúdos específicos. Kenski (2003) também comenta que não basta fornecer aos professores o conhecimento, instrucional e breve, de como operar os equipamentos, para que se possa ter condições suficientes para fazer do novo meio um auxiliar do ensino; é necessário que as atividades de treinamento e aproximação entre professores e tecnologias devem ser realizadas, o quanto antes, sendo que o início desse processo deve ocorrer, de preferência, nas licenciaturas e nos cursos de pedagogia.

Os professores precisam treinar e desenvolver suas habilidades no uso de tecnologias, precisam de tempo para transferir as habilidades adquiridas na inclusão de tecnologias no currículo (Brand, 1997). Para Hakkarainen, et al. (2001), os professores precisam, não somente se familiarizar com as tecnologias, mas também adquirir habilidades pedagógicas para usufruir dos recursos dos ambientes de aprendizagem baseados em tecnologia. Novas práticas pedagógicas devem ser exploradas e desenvolvidas para facilitar a habilidade de aquisição de conhecimento.

Muitas vezes, os treinamentos enfocam o uso dos equipamentos mas esquecem da importância de como integrar a tecnologia no currículo (Muir-Herzig, 
2004). Para integrar computadores, os professores devem ter acesso à tecnologia. Os professores devem incluir no processo de entendimento do currículo o seu uso e como incorporar a tecnologia em suas aulas (Byrom, 1997). Para Roschelle, et al. (2000), o professor é o condutor necessário para a integração de novas tecnologias em sala de aula. No estudo realizado por Muir-Herzig (2004), a incorporação dessas tecnologias inclui a preparação do professor, instrução de ensino e aprendizagem do aluno.

\subsection{A Integração de Tecnologias}

Nas últimas três décadas houve um aumento no uso de tecnologia em muitos setores, entretanto a sua integração nos métodos e práticas de ensino dos professores não tem sido completamente implementada (Pope, et al., 2002). Para verificar como está ocorrendo a integração de tecnologias na prática docente, este trabalho apresenta, no item 2.4, pesquisas realizadas em vários Estados brasileiros.

Do ponto de vista de Moran (2002), caminhamos para uma flexibilização de cursos, tempos, espaços, gerenciamento, interação, metodologias, tecnologias, avaliação, o que nos obriga a experimentar pessoal e institucionalmente a integração de tecnologias audiovisuais, impressas além da Internet. Para o autor, a época em que vivemos é de grandes desafios, no ensino focado na aprendizagem, e vale a pena pesquisar novos caminhos de integração do humano e do tecnológico; do sensorial, emocional, racional e do ético; do presencial e do virtual; de integração da escola, do trabalho e da vida.

Segundo Swan, et al. (2002), até recentemente, a integração de tecnologias no processo de ensino/aprendizagem era definida como equipar escolas com computadores, e ainda hoje, muitos parecem ter pensamento semelhante. Porém, avanços tecnológicos levaram a uma ampliação dessa definição. Pode-se dizer que a integração de tecnologias se refere ao seu uso em atividades diárias de ensino e aprendizagem, e que o desenvolvimento profissional para sua integração deve ter um enfoque semelhante. Porém, o desenvolvimento profissional baseado em tecnologia, de certa forma, não foi investigado, e os poucos estudos feitos sugerem que tem tido pouco impacto na integração diária de tecnologias computacionais na sala de aula 
(Swan, et al., 2002).

A informática, aplicada à educação, não trata somente do uso do computador, nem mesmo do seu uso em um ambiente reservado dentro da escola, mas sim, pressupõe a incorporação desse novo paradigma tecnológico passando por todas as atividades e espaços escolares e sendo incorporado por todos os sujeitos que interagem nesse ambiente, começando pelo organizador da atividade escolar: o professor (Vermelho, et al., 1998).

O processo de incorporação de tecnologias no trabalho do professor deve ser efetivado em fases, iniciando-se com o contato dele com as mesmas, voltado para o seu cotidiano. Este é um pré-requisito para que o processo de incorporação de tecnologias se dê, efetivamente, propiciando um ensino de qualidade, caso contrário, ele será artificial e superficial, limitando o seu uso (Vermelho, et al., 1998). Este prérequisito foi levado em consideração no desenvolvimento da metodologia proposta neste trabalho e descrita no capítulo 4.

De acordo com Kenski (2003), para realizar um ensino de qualidade, é necessário muito mais do que possuir avançados equipamentos disponíveis; do que a boa vontade ou a submissão do professor às instruções dos técnicos que orientam sobre o uso dos computadores e demais equipamentos; do que os breves cursos de “introdução” aos programas e softwares que a escola dispõe para uso didático; é necessário, sobretudo, que os professores se sintam “confortáveis” para utilizar esses novos auxiliares didáticos, ou seja, devem conhecê-los, dominar os principais procedimentos técnicos para sua utilização, avaliá-los criticamente e criar novas possibilidades pedagógicas, partindo da integração desses meios com o processo de ensino.

Estudo realizado por Galloway (1997) (apud Nisan-Nelson, 2001), indicou que a maioria dos professores que usou tecnologia em suas aulas também a usou em sua vida pessoal. Nisan-Nelson (2001) completa que, para poder integrar, eficazmente, tecnologias no ambiente educacional, os professores precisam ser capazes de integrar tecnologias em suas vidas pessoais também. Segundo Bitner e Bitner (2002), a habilidade e a atitude do professor determinam a eficácia da integração de tecnologias, apesar de muitos trabalhos darem atenção ao uso apropriado de software e hardware.

A integração de tecnologias no processo educacional produz mudanças 
na sala de aula. Essa mudança depende do que o professor faz e no que ele pensa (Fullan, 1982 apud Bitner e Bitner, 2002). Portanto, o professor deve aprender a usar a tecnologia e permitir que ela mude o seu paradigma de ensino, o que não é uma tarefa fácil, pois a mudança pode intimidar (Bitner e Bitner, 2002). Por isso, são necessários modelos para emular uma integração eficaz de tecnologias.

Para a tecnologia ser usada e integrada eficazmente no processo de ensino/aprendizagem, Rieber e Welliver (1989) (apud Nisan-Nelson, 2001) propõem uma teoria hierárquica de integração de tecnologias contendo cinco níveis: Familiarização, Utilização, Integração, Reorientação e Evolução, os quais são descritos a seguir (Rieber e Welliver, 1989 apud Nisan-Nelson, 2001):

1. Familiarização. Professores se informam sobre as tecnologias disponíveis em seu ambiente de trabalho e sobre o seu uso.

2. Utilização. Professores aprendem a utilizar as tecnologias disponíveis.

3. Integração. É nesta fase que a tecnologia é essencial para o processo educacional. Os professores começam a integrar a tecnologia no currículo. Para muitos professores, esta á a etapa final, porém, na realidade, é somente o começo do entendimento da função da tecnologia na educação.

4. Reorientação. É na fase de reorientação que o professor começa a redefinir sua função como profissional em relação aos alunos. $\mathrm{O}$ professor adquire novas responsabilidades e se torna um facilitador no uso de tecnologias, para permitir que o aluno adquira mais responsabilidades no processo de aprendizagem. A tecnologia cria um ambiente centrado mais na aprendizagem, com o professor trabalhando em conjunto com os alunos e deixando que eles tomem iniciativa de como e o que aprender.

5. Evolução. A evolução é um processo contínuo. Os professores começam a trabalhar em conjunto com os administradores da escola para identificar problemas educacionais e então desenvolver soluções educacionais. Os professores se tornam administradores da tecnologia, pois agora eles começam a avaliar novos recursos tecnológicos e novas habilidades necessárias para 
usá-la.

Essa teoria será retomada mais adiante, como suporte teórico, no desenvolvimento de uma metodologia para integração de tecnologias e produção de material multimídia.

Depois de anos de trabalho com professores e tecnologia e a partir de uma síntese de pesquisa, Bitner e Bitner (2002) identificaram oito áreas de consideração, que mostraram ser importantes, por permitirem que os professores tenham sucesso na integração de tecnologias. Segundo os autores, essas áreas podem parecer básicas, porém, não são fáceis de serem realizadas, pois requerem planejamento e desempenho, bem como tempo e dinheiro. São elas:

1. Mudanças. Utilizar tecnologia, como ferramenta de ensino e aprendizagem, em sala de aula, envolve mudanças nos procedimentos durante a aula e no uso de técnicas, freqüentemente, não familiares aos professores. Ajudá-los a sobrepor essas dificuldades é importante para o sucesso do programa.

2. Treinamentos básicos. Os professores precisam ter conhecimentos de como operar um computador.

3. Uso pessoal. Possuir habilidade em usar editores de texto, por exemplo, facilita aos professores começar a ver meios de integrar tecnologias em sala de aula.

4. Modelos pedagógicos. Os professores precisam saber como usar programas para facilitar o ensino e a aprendizagem, o que pode se tornar mais fácil, se eles virem exemplos de tecnologias que foram integradas no currículo e como foi feita essa integração.

5. Aprendizagem. O uso de tecnologias, em sala de aula, deve visar a aprendizagem, permitindo que professores e alunos sejam parceiros nesse processo. A integração de tecnologias altera o paradigma tradicional do professor ensinar e do aluno adquirir conhecimentos. Os alunos devem aprender a pesquisar e descobrir conhecimentos, a comunicar-se ativamente com outros e a resolver problemas.

6. Ambiente. Um ambiente deve ser criado para permitir que os 
professores façam experiências, sem sentir medo de errar. O mais importante é que eles se sintam à vontade, caso cometam erros no uso de tecnologias em suas aulas, sem receio da reação dos alunos ou de superiores.

7. Motivação. Motivação para suportar a frustração e os tumultos do processo de mudança. Geralmente a motivação aparece quando os professores vêem as possibilidades que a tecnologia pode oferecer às suas aulas e aos seus alunos.

8. Suporte. Professores precisam de suporte para serem eficientes no uso de tecnologias em sala de aula. Precisam de suporte na área técnica e na área de currículo. Principalmente na área técnica, é necessário que uma pessoa especializada dê suporte, caso venham a ocorrer problemas com o hardware ou o software durante a aula.

\subsection{Exemplos de Aplicação de Tecnologias em Sala de Aula}

Pesquisas recentes têm sido realizadas sobre o uso das tecnologias voltadas para a área educacional, em várias modalidades de ensino. Algumas delas discutem a questão teórica, também importante para a área, como Cordeiro (2000), Silva, C. M. C. (2000), Diniz (2001), Hakkarainen, et al. (2001), Melo (2001). Outras pesquisas são experimentos relacionados com aspectos particulares da questão, como o uso de aplicativos, de recursos básicos da Internet e de softwares educacionais, que são apresentados a seguir.

\section{- Uso de aplicativos e de recursos básicos da Internet}

Algumas pesquisas apresentam o uso de aplicativos, como editores de texto, planilhas eletrônicas, e de recursos básicos da Internet, como e-mail, chat, páginas Web, searchers (pesquisadores). Essas pesquisas foram realizadas em escolas públicas de diversos Estados: São Paulo, Paraná, Santa Catarina e Minas Gerais, e apenas uma foi realizada em uma universidade. Dentre elas, Chudzikiewicz (2000) e Descrovi (2002) fizeram um estudo do que vem sendo usado por 
professores em suas aulas e verificaram que eles utilizam Internet, para pesquisa além de e-mail, Word e Excel. Já Silva, V. S. P. (2000) propôs uma metodologia que utilize esses recursos. Porém, Souza (2000) revelou que a maioria dos professores que usam o computador em suas aulas, utiliza apenas o Word, mesmo tendo conhecimentos da Internet. Com relação à eficiência dessas tecnologias na educação, Almeida (2002) verificou a importância do uso de um editor de texto como contribuição em experiências com crianças com dificuldades de aprendizagem; Magalhães (1997), Schiel, et al. (2000) e Schiel, et al. (2002a) verificaram a eficiência dos recursos da Internet, Web e e-mail, para fins de EAD. Dessa maneira, vê-se que o que mais se aplica com os alunos das escolas públicas é o editor de texto e que os professores que usam a Internet em suas aulas, geralmente, utilizam os recursos de pesquisa e e-mail.

\section{- Uso de softwares educacionais}

Alguns trabalhos estudam a utilização de softwares educacionais para auxílio ao ensino. Os estudos realizados por Magalhães, et al. (2002), Schiel, et al. (2002b) e Schiel, et al. (2002c), onde o Software para Análise de Movimentos $(\mathrm{SAM})^{5}$ (Minatel e Schiel, 1999) foi utilizado como uma nova tecnologia em sala de aula, no auxílio ao ensino de Física, levaram em consideração as atividades desenvolvidas por professores em escolas públicas de Ensino Médio do interior do Estado de São Paulo. Seu objetivo é fornecer ao professor as ferramentas necessárias para o ensino de Física, através de experimentos práticos, utilizando técnicas de Processamento Digital de Imagens ${ }^{6}$. Os resultados das avaliações mostraram que o aluno ficou motivado durante o seu uso, procurando interpretar o mundo real por meio dos movimentos analisados com o software, os quais fazem parte do seu cotidiano.

Lessie (2001) aplicou o software World in Motion ${ }^{7}$ em uma aula de mecânica, com alunos de um colégio em New Jersey, EUA. Em seu trabalho,

\footnotetext{
${ }^{5}$ http://educar.sc.usp.br/sam

${ }^{6}$ Essas técnicas possibilitam a observação de muitos fenômenos físicos, como a propagação de ondas, reflexão, refração, velocidade de propagação de ondas, velocidade de objetos em movimentos, constatação de movimentos retilíneos ou curvos, constantes ou acelerados, dentre muitas outras aplicações (Minatel; Schiel, 1999).

${ }^{7}$ http://members.aol.com/raacc/wim.html
} 
também foi enfatizada a análise quantitativa de movimentos para descrever e entender os fenômenos físicos do cotidiano do aluno. Nessa experiência, assim como na apresentada anteriormente, observou-se que os alunos se sentiram motivados por analisarem vídeo de fenômenos do seu cotidiano. A nova versão desse software inclui o desenvolvimento de páginas HTML (Hypertext Markup Language) para serem disponibilizadas na Internet.

Barbeta e Yamamoto (2002) apresentaram o Programa de Análise de Imagens como mais uma ferramenta para auxílio no ensino da Física. O software foi aplicado com alunos universitários do primeiro ano e os resultados obtidos indicaram que a possibilidade de análise de diferentes tipos de movimento, torna esse tipo de ferramenta bastante interessante para uso didático.

As três pesquisas apresentadas destacam o uso de software para análise de movimentos, filmados do cotidiano ou produzidos em laboratório, como auxílio no ensino da Física. Todos os softwares possuem características semelhantes e os resultados das suas aplicações demonstraram interesse e motivação, por parte dos alunos, em estudar os movimentos armazenados em vídeo através desses softwares educacionais.

\section{- Alguns projetos que utilizam recursos avançados da Internet e outras tecnologias}

Alguns projetos usam outras tecnologias, como câmera de vídeo, lousa eletrônica, microfones e recursos avançados da Internet, como por exemplo, linguagem Java, XML (Extensible Markup Language), $\mathrm{SMIL}^{8}$ (Synchronized Multimedia Integration Language), PHP (Hypertext Preprocessor), necessitando de outros servidores, como o de vídeo, além dos servidores Web, de e-mail, etc.

\section{a) Lectures on Demand - University of Florida}

A metodologia Lectures on Demand in Asynchronous Learning Network (ALN) do Departamento de Engenharia Elétrica e da Computação (Electrical and Computer Engineering Department) da Universidade da Flórida, USA, possui uma infra-estrutura composta por um Servidor de vídeo (RealServer) e um Servidor Web

\footnotetext{
${ }^{8}$ Ver Apêndice II e o site http://www.w3.org/TR/REC-smil/, para mais informações sobre o SMIL.
} 
(figura 1). Os programas utilizados são o RealProducer ${ }^{9}$ da RealNetworks e o WebCT $^{10}$.

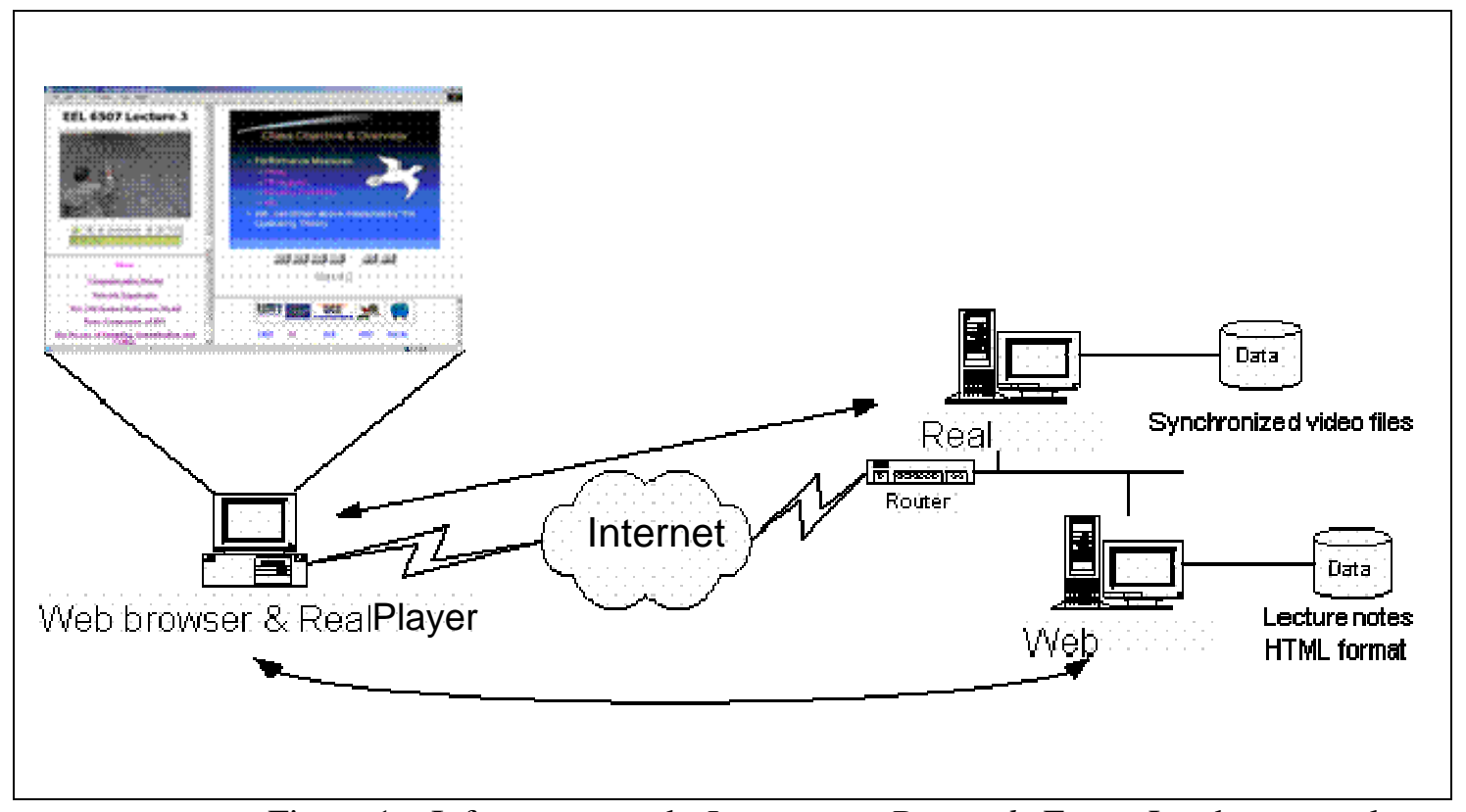

Figura 1 - Infra-estrutura do Lectures on Demand. Fonte: Latchman, et al. (2002).

O RealProducer é utilizado para a criação de vídeo digital, onde aulas ao vivo são codificadas e distribuídas via Internet (modo síncrono), ao mesmo tempo em que fluxos (streams) de áudio e vídeo vão sendo arquivados em um servidor de vídeo para serem vistos posteriormente (modo assíncrono). Streamings de vídeo e áudio armazenadas também podem ser sincronizadas com materiais de aula, como slides do PowerPoint, através da linguagem SMIL. Esse material fica disponível em um ambiente virtual de um curso criado no WebCT, o qual foi usado para gerar e oferecer cursos online ou, simplesmente, publicar material complementar ao curso (Latchman, et al., 1999).

A figura 2 mostra exemplo de um material multimídia de um curso disponível no ambiente WebCT, contendo vídeo (criado pelo RealProducer), slides do PowerPoint e, em uma janela inferior à esquerda, links para as ferramentas do WebCT como chat, e-mail e lista de discussão. Esse material multimídia fica disponível em um ambiente virtual do curso.

\footnotetext{
${ }^{9}$ O RealProducer é um software para criação de áudio e vídeo para Internet no formato Real, um dos primeiros formatos desenvolvidos, especificamente, para a transmissão de vídeo digital pela Internet no formato stream (http://www.realnetworks.com).

${ }^{10} \mathrm{http}: / / \mathrm{www} \cdot \mathrm{webct} . \mathrm{com}$
} 


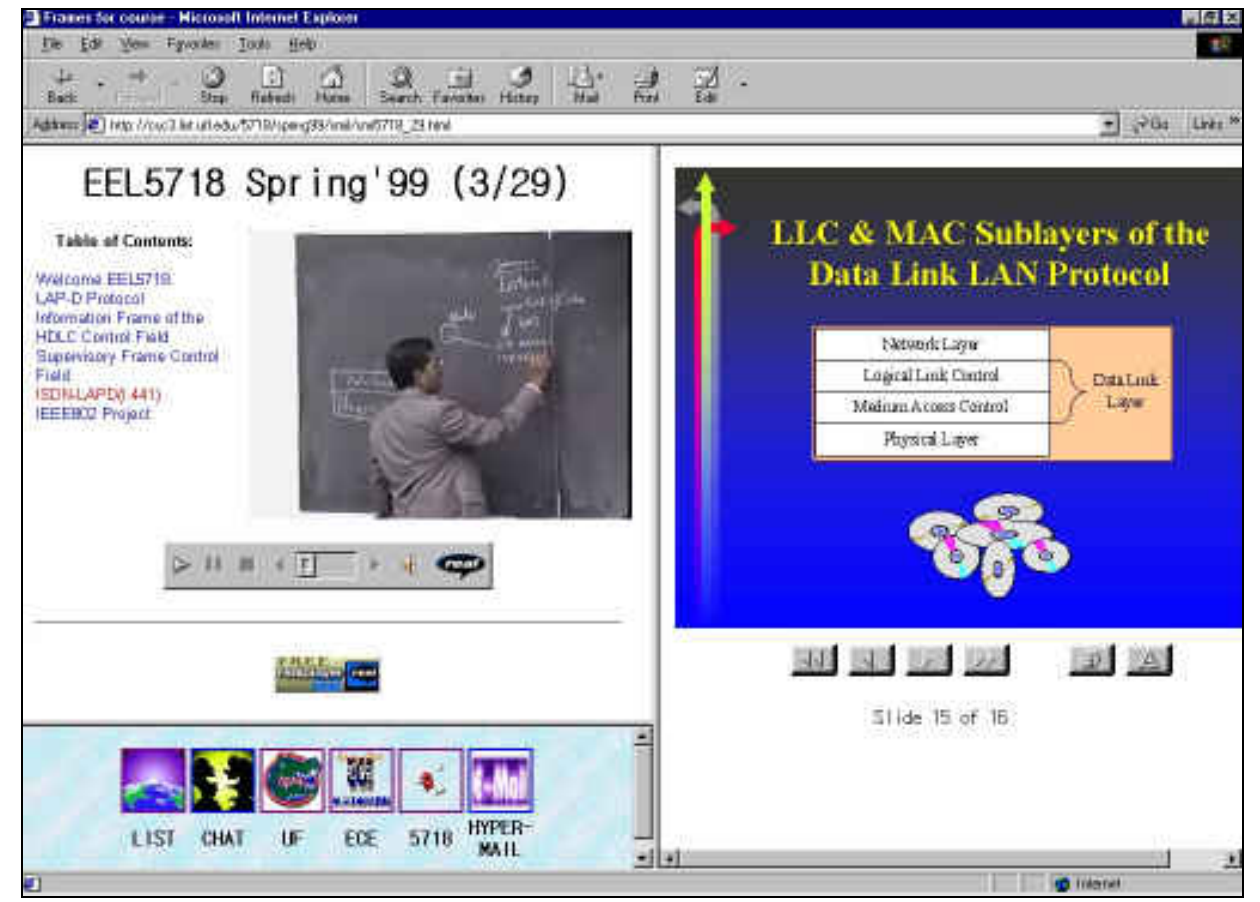

Figura 2 - Material multimídia de um curso virtual da Universidade da Flórida no ambiente WebCT. Fonte: Latchman, et al. (1999).

\section{b) eClass ${ }^{11}$ - Georgia Institute of Technology}

O projeto eClass (Electronic Classroom) (Abowd, et al., 1996; Abowd, 1997; Abowd, 1999; Pimentel, et al., 2000; Brotherton, 2001; Pimentel, et al., 2001) do Georgia Institute of Technology, Atlanta, USA, tem como objetivo avaliar e entender o efeito da computação ubíqua ${ }^{12}$ no ambiente educacional universitário, dando enfoque ao desenvolvimento de uma infra-estrutura de hardware e de software para "suportar" melhor aprendizagem em sala de aula convencional, no sentido de melhorar a prática atual e sugerir novas formas de educação (Abowd, et al., 1996).

A infra-estrutura de software do ambiente eClass constitui-se de um conjunto de aplicações cliente-servidor, possuindo módulos de captura, de sincronização, de armazenamento de informação e de geração automática de hiperdocumentos baseados na Web. A instalação de hardware completa do eClass seria uma sala de aula equipada com lousa eletrônica, projetores, microfones e câmera de vídeo (Pimentel, et al., 2000).

\footnotetext{
${ }^{11} \mathrm{http}: / /$ www.cc.gatech.edu/fce/eclass/index.html

${ }^{12}$ De acordo com Mark Weiser, computação ubíqua é uma forma pouco intrusiva de integrar tecnologias às atividades do cotidiano das pessoas (Weiser, 1993). São exemplos de dispositivos computacionais ubíquos: PDA (Personal Digital Assistant), laptop, lousa eletrônica, telefone celular, dentre outros.
} 
O eClass é composto por um conjunto de programas Java, chamado ZenStar (Zen*), responsável pela captura e sincronização das streams de informação, durante cada sessão ao vivo. Suas tarefas incluem ainda a geração dos documentos associados quando a sessão é encerrada. Como resultado desse processo, poucos minutos após a conclusão da sessão, um hiperdocumento Web é automaticamente gerado e disponibilizado para acesso (Pimentel, et al., 2000). Scripts PHP possibilitam uma interface HTML dinâmica para visualizar as sessões capturadas. Para que esses componentes trabalhem juntos há necessidade de vários servidores; no Georgia Institute of Technology utilizam um Servidor Apache (Apache Software Foundation) como Servidor Web; um Servidor Real (RealNetworks) para streams de áudio e vídeo e um Servidor MySQL (Open Source) como servidor de Base de Dados (Brotherton, 2001). Ao contrário da experiência na Universidade da Flórida com modo síncrono e assíncrono, o eClass possibilita acesso assíncrono às informações disponíveis na Internet. A figura 3 mostra um hiperdocumento gerado automaticamente pelo eClass.

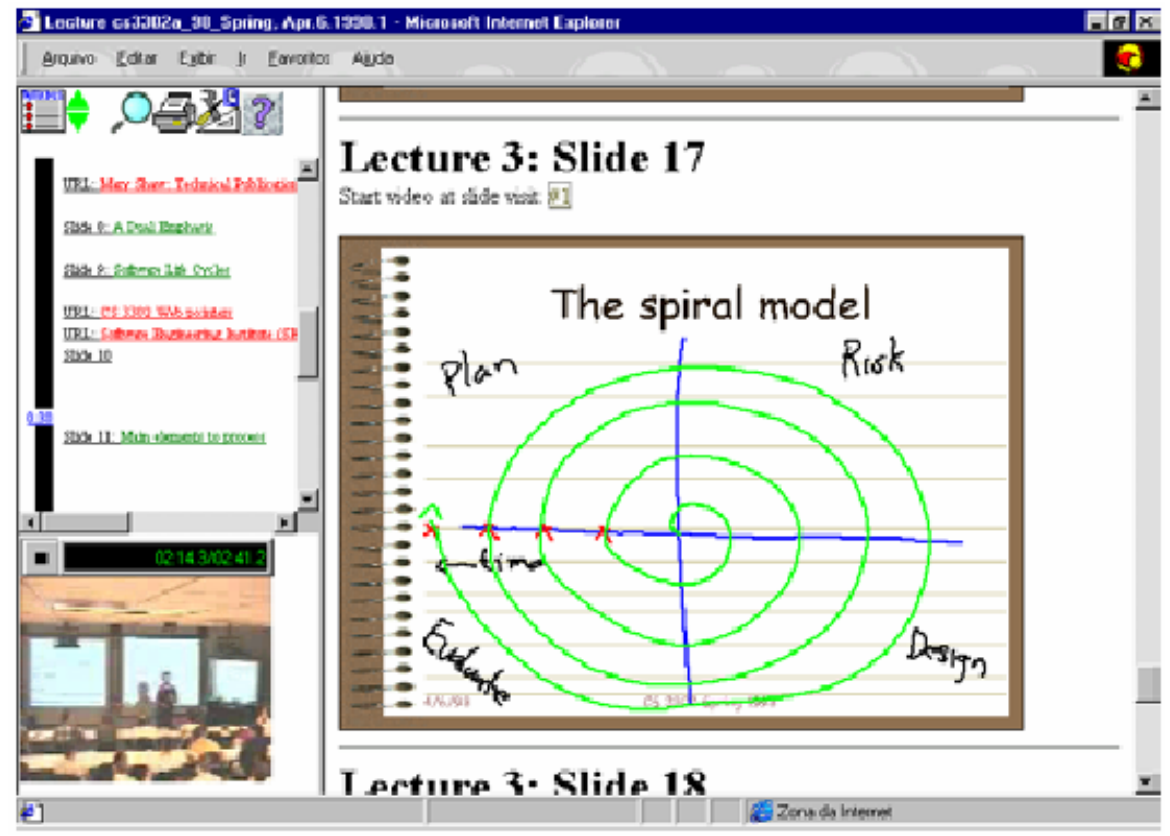

Figura 3 - Hiperdocumento gerado automaticamente pelo eClass. Fonte: Pimentel, et al. (2000).

\section{c) iClass - Instituto de Ciências Matemáticas e de Computação (ICMC/USP)}

No ICMC/USP foi desenvolvido um sistema para captura de sessão em ambiente educacional, o iClass. Esse sistema é, em termos de estruturação de software, uma evolução do eClass e apresenta algumas melhorias (Cattelan, et al., 
2003):

- Uso de um modelo de desenvolvimento estruturado, baseado em infra-estruturas e serviços, facilitando a escalabilidade e a manutenção do sistema;

- Armazenamento da informação como documentos XML em um banco de dados XML nativo;

- Uso de padrões consolidados, como XHTML (Extensible Hypertext Markup Language) e SMIL, para a apresentação da informação capturada (figura 4), sendo os documentos XML gerados na fase de captura e processados de acordo com folhas de estilo XSLT (Extensible Stylesheet Language Transformation);

- Interface em português.

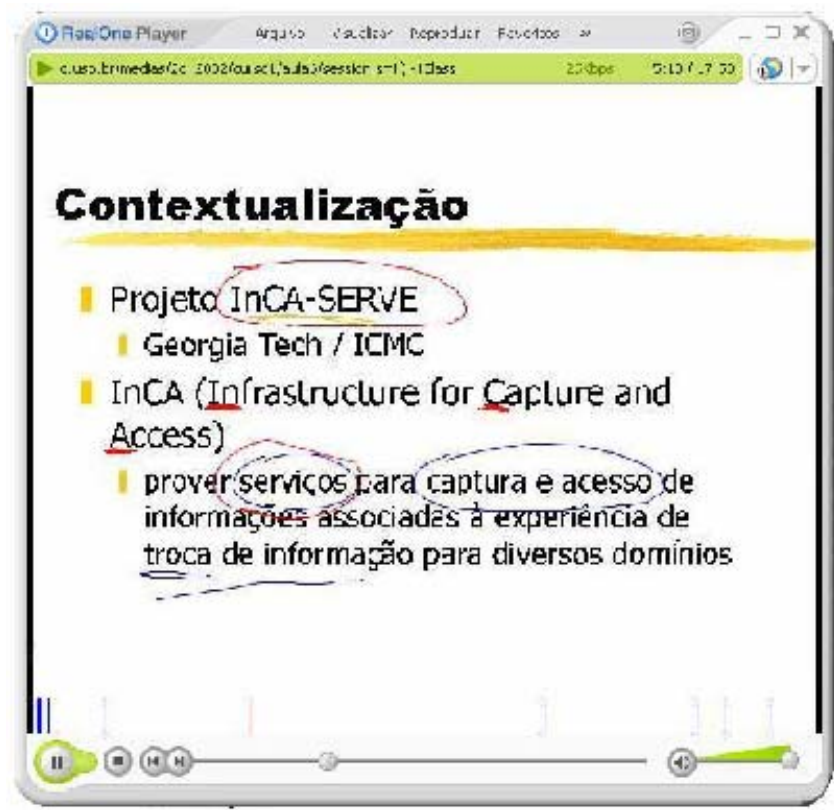

Figura 4 - Interface de apresentação SMIL da informação de uma sessão capturada. Fonte: Cattelan, et al. (2003).

\section{d) Centro de Computação da UNICAMP (CCUEC/UNICAMP)}

Uma vez que a linguagem SMIL pode ser usada tanto em uma apresentação como no conteúdo de um curso à distância, a equipe de EAD da Unicamp, testou e utilizou essa linguagem por meio do RealSlideshow ${ }^{13}$ da

${ }^{13}$ O RealSlideshow é uma ferramenta que gera apresentações em SMIL (Scherrer, 2001). Mais informações no site http://www.realnetworks.com. 
RealNetworks, primeiramente em uma palestra "Educação à Distância e Tecnologia”"14, ministrada pelo Prof. Dr. Eduardo Chaves, no CCUEC (figura 5). Usou-se essa tecnologia como solução de dificuldades encontradas na transmissão pela Internet e disponibilização das palestras de EAD no CCUEC. Por exemplo, quando o palestrante fazia referência a um slide apresentado, a imagem exibida no telão não possuía qualidade suficiente para ser gravada e apenas era registrada a imagem do palestrante em vídeo (Scherrer, 2001).

Como o objetivo era fazer uma apresentação mostrando ao mesmo tempo o palestrante e os slides, utilizou-se a linguagem SMIL, permitindo que o usuário, através de um menu, avançasse para um determinado ponto da palestra do seu interesse, sem a necessidade de assisti-la inteiramente. Dessa forma, com essa nova tecnologia, ganhou-se em qualidade e na interação com a pessoa que estiver assistindo, de forma assíncrona, deixando a apresentação da palestra com um aspecto profissional (Scherrer, 2001).

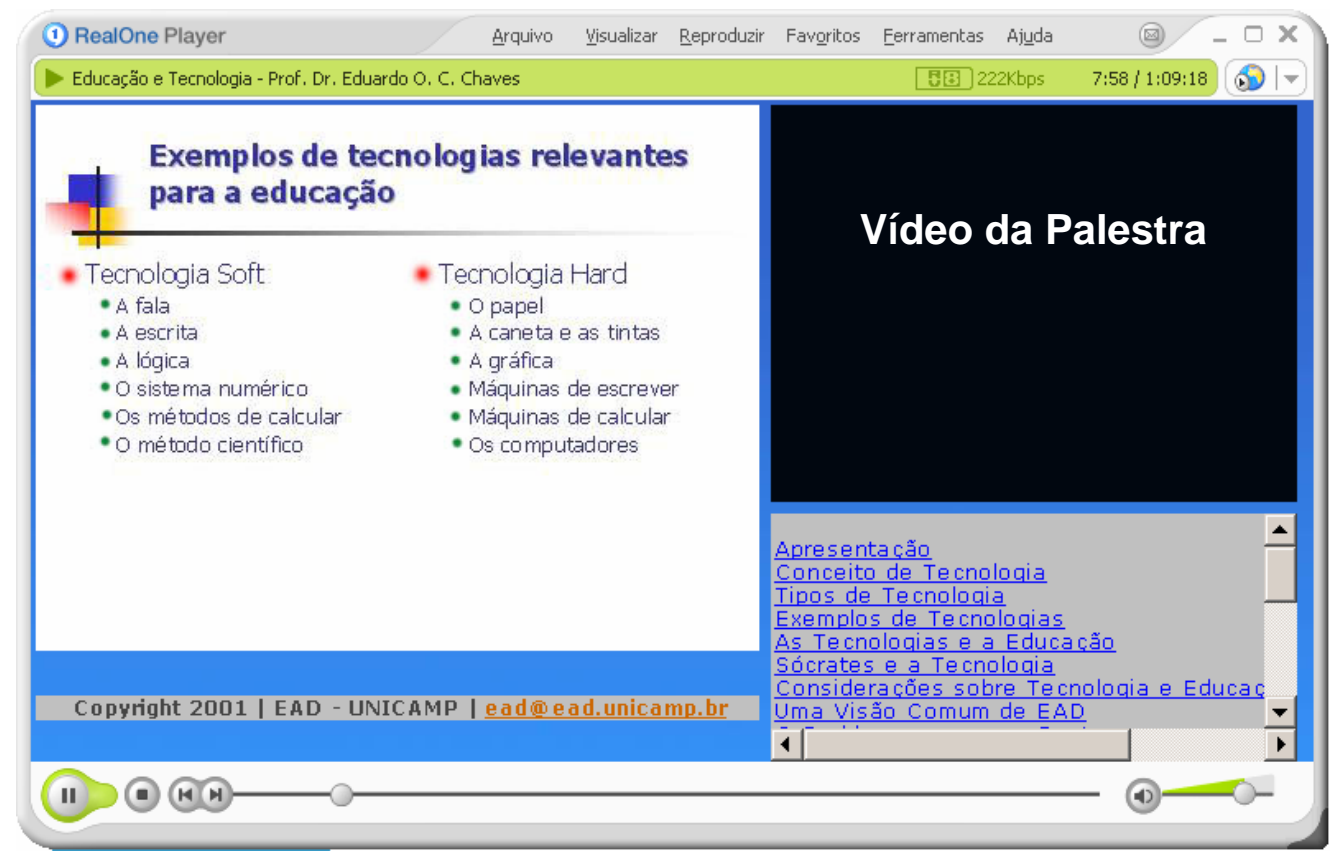

Figura 5 - Exemplo de uma palestra virtual desenvolvida pela equipe de EAD da UNICAMP.

\footnotetext{
${ }^{14}$ http://www.ead.unicamp.br/eventos/evento.html
} 


\subsection{Considerações Finais}

A utilização das novas tecnologias em ambientes educacionais multiplicou enormemente as possibilidades de pesquisa de informação e tornou o processo de ensino/aprendizagem, em ambiente informatizado, mais interativo, colocando à disposição de alunos e professores um manancial inesgotável de informações e implicando em nova postura por parte dos professores.

Pôde-se perceber que a tecnologia não só muda as atitudes dos professores como desenvolve habilidades que eles não possuíam anteriormente. Os professores têm diferentes razões para usar a tecnologia, mas os que a integram em suas aulas são aqueles que possuem mais experiência no ensino e no seu uso prático e constante.

Dos exemplos apresentados, verificou-se que, em escolas públicas de vários Estados brasileiros, a maioria dos professores que utilizam tecnologias em suas aulas, usa um editor de texto e os que usam a Internet, geralmente, a utilizam para planejamento de aula. Os projetos desenvolvidos nas universidades e apresentados anteriormente, utilizam infra-estrutura cliente-servidor, necessitando de Servidor Web, Servidor de vídeo, dentre outros. Usam softwares já prontos para a elaboração de conteúdo multimídia ou, em certos casos, desenvolvem seu próprio ambiente computacional, o que também necessita de uma infra-estrutura avançada. Vistos os resultados dos exemplos das escolas públicas, decidiu-se por apresentar uma proposta que atenda à formação inicial de professores, orientando-os no uso de outras tecnologias, que não seja apenas o editor de texto e podendo utilizar, como infra-estrutura, o computador da escola ou o seu próprio.

Acredita-se, ainda, que a introdução bem-sucedida de novas tecnologias no processo de ensino/aprendizagem, exige compreensão, por parte do professor, do porque e de como utilizar as novas tecnologias, familiarizando-se com as mesmas. Para isso, parece necessário refletir sobre a utilização de tecnologias durante a formação de professores. Como o foco principal deste trabalho é o futuro professor, em sua formação inicial, também se torna necessário estudar sobre a aprendizagem da docência, que será tratada no próximo capítulo. 


\section{A Formação de Professores e as Novas Tecnologias}

\subsection{Introdução}

Neste capítulo, será delineado o objeto a ser investigado, mostrando a importância da tecnologia na formação de professores, trazendo a opinião de autores que demonstram preocupação com o sistema educacional, com a forma do professor ensinar e com a aprendizagem da docência, apresentando exemplos de aplicação de tecnologias na formação de professores. Neste trabalho será levada em consideração a formação de professores, em geral e da tecnologia, em especial.

\subsection{Formação de Professores: Considera- ções Gerais}

(...) "introduzir novas tecnologias, democratizar o ensino, diferenciar a pedagogia para melhor lutar contra o insucesso escolar, renovar os conteúdos e as didáticas, desenvolver as pedagogias ativas, participativas, cooperativas, abrir a escola à vida, partir da vivência dos alunos, reconhecer a diversidade das culturas, alargar o diálogo com os pais, favorecer a sua participação na vida da 
escola: tudo isto conduz-nos sempre à conclusão de que é preciso formar os professores!” (Perrenoud 1997, p. 93).

Segundo Jacques Plante (apud Perrenoud, 1997), formar professores significa prepará-los para observar, decidir e agir em certas situações, tendo em conta o conjunto dos objetivos e dos constrangimentos que caracterizam a ação pedagógica em sala de aula.

Aprender a ensinar e a se tornar professor não são eventos; são processos pautados em diversas experiências e modos de conhecimento, os quais são iniciados antes da preparação formal e que prosseguem ao longo desta, permeando toda a prática profissional vivenciada (Mizukami, et al., 2002).

O desafio para a formação de professores consiste em conceber a escola como um ambiente educativo, onde trabalhar e formar não sejam atividades distintas, sendo a formação encarada como um processo permanente, integrado no dia-a-dia dos professores e das escolas (McBride, 1989 apud Nóvoa, 1995).

A literatura vem apontando que a formação de professores não se dá somente nos cursos de formação inicial, mas acontece desde os seus primeiros anos de escolarização (Simião e Reali, 2002). Lima (1996) (apud Simião e Reali, 2002) afirma que o processo de tornar-se professor é infindável, começando antes de sua formação básica e se estendendo para além dela. Para Kenski (2003), a formação do professor não se dá apenas durante o seu percurso nos cursos de formação de professores, mas durante todo o seu caminho profissional, dentro e fora da sala de aula.

Muito se discute que os currículos de formação de professores são amplamente determinados e influenciados por demandas sociais, políticas e econômicas, em cada momento histórico, e que, freqüentemente, necessitam ser reformulados para se adaptarem às novas concepções sobre ensinar e aprender a ensinar (Simião e Reali, 2002).

Torres (1999) (apud Mizukami, et al., 2002) aponta que a ênfase das políticas sobre a formação de professores recai sobre a aprendizagem e o rendimento escolar dos alunos, desconsiderando uma questão fundamental que é a aprendizagem daquele que ensina. Para a autora, construir uma escola diferente implica em um compromisso prioritário com a transformação do modelo tradicional de formação de 
professores, pois não se pode exigir que docentes realizem em suas aulas o que não vêem aplicado na própria formação. Portanto, a autora propõe alguns princípios a fim de nortear as políticas no campo da formação de professores (Torres, 1999 apud Mizukami, et al., 2002):

- Docentes como sujeitos e não como beneficiários, tendo uma participação ativa nos planos e programas de políticas públicas.

- Visão estratégica e estratégia a longo prazo. Formar recursos humanos é um investimento a longo prazo que exige esforços sistemáticos e sustentáveis.

- Articular formação inicial e formação em serviço, onde é inerente à própria concepção de aprendizagem e de desenvolvimento profissional da docência, entendida como um processo contínuo ao longo da vida.

- Recuperar pontos de partida (perspectiva na qual se aplica o que se aprende) e pontos de chegada (perspectiva a partir da qual se tende a aplicar o que se ensina).

- Um sistema de formação de professores ao mesmo tempo unificado e diversificado. É preciso diversificar modalidades, conteúdos, pedagogias, tecnologias, mais do que uniformizar a formação de professores, de forma a responder aos perfis e às possibilidades de cada contexto, buscando a unidade e a coerência da formação de professores como um sistema.

- Formação, mais que treinamento. O desafio está em pensar uma formação integral, orientada fundamentalmente a aprender a pensar, a refletir criticamente, a identificar e resolver problemas, a investigar, a aprender, a ensinar, e não se limitar à mera transferência de conteúdo, métodos e técnicas.

De acordo com Simião e Reali (2002), a maioria dos cursos de formação de professores tem seus currículos apoiados no modelo de racionalidade técnica. Nesse modelo, a atividade profissional é sobretudo instrumental, dirigida para a solução de problemas mediante a aplicação estrita de teorias e técnicas científicas, onde, segundo Pérez Gómez (1995), dá-se, inevitavelmente, a separação pessoal e 
institucional entre a investigação e a prática.

Segundo Mizukami, et al. (2002), aprender a ser professor, nesse contexto, não é tarefa que se conclua após estudos de um aparato de conteúdo e técnica de transmissão dele. Para os autores, é uma aprendizagem que deve se dar por meio de situações práticas que sejam efetivamente problemáticas, o que exige o desenvolvimento de uma prática reflexiva competente e que, além de conhecimentos, sejam trabalhadas atitudes, as quais são consideradas tão importantes quanto os conhecimentos. Sendo assim, a racionalidade técnica não dá mais conta da formação de professores.

Pérez Gómez (1995) afirma que o modelo de racionalidade técnica apresenta limites e lacunas profundas e significativas. Os limites desse modelo se encontram no fato de não levar em conta os aspectos do contexto mais amplo em que as práticas educativas estão inseridas (Mizukami, et al, 2002). A tecnologia educativa não pode continuar a lutar contra as características, cada vez mais evidentes, dos fenômenos práticos: complexidade, incerteza, instabilidade, singularidade e conflito de valores (Pérez Gómez, 1995). E, como diz Schön (1983):

"Se o modelo de racionalidade técnica é incompleto, uma vez que ignora as competências práticas requeridas em situações divergentes, tanto pior para ele. Procuremos, em troca, uma nova epistemologia da prática, implícita nos processos intuitivos e artísticos que alguns profissionais, de fato, levam a cabo em situações de incerteza, instabilidade, singularidade e conflito de valores.”

De acordo com Pérez Gómez (1995), a atividade profissional do professor não pode ser considerada como exclusivamente técnica, sendo mais apropriado encará-la como uma atividade reflexiva e artística, onde cabem algumas aplicações concretas de caráter técnico. Na verdade, a prática deve ser considerada também como um processo de preparação técnica, na medida em que permite compreender o funcionamento das regras e das técnicas no mundo real da sala de aula e desenvolver as competências profissionais exigidas pela sua aplicação eficaz, devendo situar-se no final do currículo de formação, quando os alunos-mestres já dispõem de conhecimento científico e das derivações normativas.

Essa nova abordagem de formação de professores que enfatiza o caráter 
complexo da atividade de ensinar, aparentemente conduz à superação dos limites da racionalidade técnica pelo fato de ser pautada no saber profissional e apoiada no conceito de reflexão (Simião e Reali, 2002). De acordo com Pérez Gómez (1995), no modelo de formação de professores como artistas reflexivos, a prática adquire o papel central de todo o currículo, assumindo o lugar de aprendizagem e de construção do pensamento prático do professor. Para o seu desenvolvimento são considerados dois conceitos fundamentais relacionados à aprendizagem profissional da docência: a reflexão-na-ação e a reflexão-sobre-a-ação ${ }^{15}$.

Reflexão-na-ação - diz respeito aos processos de pensamentos que ocorrem durante a ação presente do professor e se manifesta no saber fazer. Serve para reorganizar o que está sendo feito, ou seja, reformular as ações do professor no decorrer da sua intervenção com os alunos (Simião e Reali, 2002).

Reflexão-sobre-a-ação - é a análise que o professor faz a posteriori sobre as características e processos de sua própria prática (Pérez Gómez, 1995). Simião e Reali (2002) destacam que muitos programas de formação de professores, concebidos a partir do modelo de racionalidade técnica, privilegiam este tipo de atividade geralmente no final dos cursos, pois os alunos participam de estágios e discutem as situações vivenciadas nas aulas de Prática de Ensino.

No momento da reflexão, a prática é reconstruída pelo professor a partir da observação, descrição, análise e explicitação dos fatos ocorridos, pois ao explicitar os fatos e analisá-los, surgem dúvidas e questionamentos que precisam ser esclarecidos e compreendidos (Simião e Reali, 2002).

O pensamento prático do professor é de importância vital para compreender os processos de ensino/aprendizagem, para desencadear uma mudança radical dos programas de formação de professores e para promover a qualidade do ensino na escola, numa perspectiva inovadora (Pérez Gómez, 1995).

\footnotetext{
${ }^{15}$ Na difusão do conceito de reflexão, Schön $(1983,1987)$ tem sido considerado um dos autores de maior peso e como um importante marco das reformas educativas ocorridas em inúmeros países nas décadas de 80 e 90 (Mizukami, et al., 2002).
} 


\subsubsection{Formação Inicial de Professores}

O papel da formação inicial de professores é fornecer as bases para construir um conhecimento pedagógico especializado, pois constitui o começo da socialização profissional e da assunção de princípios e regras práticas (Imbernón, 2000 apud Mizukami, et al., 2002). Apresenta-se como o início da formação contínua que acompanhará o profissional durante toda sua carreira (Perrenoud, 1997).

Segundo Perrenoud (1997), qualquer formação inicial merece ser periodicamente repensada, em função, por exemplo, da evolução das condições de trabalho ou das tecnologias. A renovação da formação inicial pode contribuir para antecipar e acelerar uma evolução global. A tarefa dos professores encontra-se globalmente alterada, pois não se trata de ensinar a todos, na esperança de que alguns aprendam muito e outros aprendam o mínimo exigido, mas sim de colocar o maior número possível em situações que permitam a quase todos aprender de um modo eficaz.

Segundo Pearson (1999), tornar o conhecimento sobre o ensino acessível e encorajar professores a adotar caminhos reflexivos na sua prática, são objetivos importantes dos cursos de formação inicial de professores. E as tecnologias de comunicação e informação possuem potencial para facilitar a realização desses objetivos. Para Perrenoud (1997), ao experimentar a reflexão sobre a prática, ao longo de sua formação inicial, é que o professor se habituará a aprender desta maneira, analisando a experiência e o seu próprio procedimento pessoal e profissional.

\subsubsection{A Tecnologia na Formação de Professores}

Em seu dia-a-dia o professor convive, cada vez mais, com as tecnologias, por isso, torna-se necessário e urgente que seja contemplado com elas, na sua formação inicial e continuada (Simião e Reali, 2002). Entretanto, segundo Sandholtz (2001), muitos desses cursos enfatizam mais a questão operacional dos computadores do que prepará-los para utilizar a tecnologia como ferramenta de ensino. A autora afirma que tanto a formação inicial de professores, quanto a continuada, devem 
trabalhar a questão de prepará-los, não somente para usar a tecnologia, mas integrá-la em sala de aula. É nesse sentido que será trabalhada esta pesquisa.

Caligiorne (2002), em seu trabalho com futuros professores de um curso de Estudos Sociais, constatou que a incorporação da informática na formação de professores exige maior empenho dos mesmos, uma vez que é preciso que se realize a articulação entre a exploração da tecnologia computacional e a ação pedagógica com o uso do computador e das teorias educacionais.

Segundo Kenski (2003), os professores que procuram se relacionar com as novas tecnologias, possuem queixas e observações semelhantes sobre a baixa qualidade didática de muitos dos programas que são comercializados e introduzidos como pacotes pedagógicos, nas escolas de diversos níveis de ensino. Para a autora, uma das soluções seria a possibilidade de participação dos educadores na produção de conteúdos adequados que usem novas tecnologias, sendo que, para isso, é preciso que os cursos de formação de professores se preocupem em lhes garantir novas competências e que, ao lado do saber científico e pedagógico, sejam-lhes oferecidas condições para ser agente, produtor e crítico dessas novas tecnologias aplicadas no ambiente educacional.

Nessa perspectiva, este trabalho sugere a participação do futuro professor na produção de um material educacional multimídia, de forma que o mesmo o elabore com informações obtidas, antes ou durante, uma aula ministrada. Para isso, sentiu-se a necessidade de um curso de formação inicial de professores que ofereça esta nova proposta como disciplina do seu currículo.

A formação qualitativa do professor deve ser vista como um amplo quadro de complementação às tradicionais disciplinas pedagógicas e que inclua algum conhecimento sobre o uso crítico das novas tecnologias (não apenas do computador e da Internet, mas outras mídias como o vídeo, etc.) nas mais variadas e diferenciadas atividades de ensino, sendo preciso que o professor saiba utilizá-las adequadamente, para poder melhor explorar suas especialidades e garantir o alcance dos objetivos do ensino oferecido (Kenski, 2003).

O uso de tecnologias na sala de aula deve considerar a natureza dos conhecimentos que os professores dispõem e como podem ser construídos (Simião e Reali, 2002). Shulman (1987) aponta que os professores se apóiam em diferentes tipos de conhecimentos para o ensino, que compõem a base de conhecimento 
pessoal. São eles:

- Conhecimento do conteúdo específico;

- Conhecimento pedagógico do conteúdo;

- Conhecimento do currículo, dos materiais e dos programas;

- Conhecimento pedagógico geral;

- Conhecimento dos alunos e das suas características;

- Conhecimento do contexto educacional;

- Conhecimento dos objetivos, metas e propósitos educacionais.

De acordo com Simião e Reali (2002), tendo em vista o uso de novas tecnologias em sala de aula, o conhecimento do conteúdo específico destaca-se, inicialmente, como fundamental, por se referir à compreensão que os professores têm sobre a matéria que ensinam. Para García (1999) (apud Simião e Reali, 2002), é necessário que os professores tenham conhecimentos adequados sobre a matéria que ensinam, pois estes podem influenciar na forma como ensinam aos alunos.

Outro elemento que é essencial na base de conhecimento dos professores, tendo em vista a utilização de tecnologias como forma de ensino, é o conhecimento pedagógico do conteúdo. Esse conhecimento representa a combinação entre o conhecimento da matéria a ser ensinada e o conhecimento pedagógico e didático de como ensiná-la (Simião e Reali, 2002). Segundo Shulman (1986), esse é um tipo de conhecimento que incorpora aspectos do conteúdo considerados mais relevantes para serem ensinados e as formas de apresentá-los, tornando-os compreensíveis aos alunos.

Para Marcelo (1998) (apud Simião e Reali, 2002), esse tipo de conhecimento se constrói a partir do conhecimento que o professor tem do conteúdo, do conhecimento pedagógico geral, e do conhecimento dos alunos; além disso, é conseqüência da própria conduta pessoal e profissional do docente.

Os conhecimentos discutidos acima são importantes para este trabalho, uma vez que sugerem que o futuro professor utilize tecnologias para o ensino tendo que desenvolver um conhecimento específico e pedagógico do conteúdo. 


\subsection{Aprendizagem da Docência: O Modelo de Shulman}

Segundo Mizukami, et al. (2002), vários pesquisadores têm oferecido importantes contribuições para o desenvolvimento de uma nova epistemologia da prática, considerando especificidades do desenvolvimento profissional do professor, como Elbaz (1983), Schön (1983, 1987, 1988), Shulman (1986, 1987), Knowles, et al. (1994), Nóvoa (1995), Calderhead (1996), Clandinin e Connelly (1996, 2000), entre outros. Segundo os autores, essas pesquisas diferem quanto às orientações teóricas e quanto aos referenciais em que se apóiam. Neste trabalho foram adotadas as contribuições de Shulman, as quais são descritas a seguir, como referencial teórico para o desenvolvimento da metodologia proposta.

Investigações sobre o raciocínio do professor vêm levantando questões relacionadas aos diferentes tipos de conhecimento pedagógico que os professores podem adquirir no decorrer de sua prática (García, 1995). A grande referência nessa linha de pesquisa é o norte-americano Lee Shulman, coordenador de um dos programas de investigação mais ambicioso e produtivo a nível internacional, intitulado "Desenvolvimento do Conhecimento no Ensino" (Knowledge Growth in Teaching). O objetivo dessa investigação foi estudar o que sabem os professores sobre os conteúdos que ensinam; onde e quando adquiriram esses conteúdos; como e porque esses se transformam durante a formação de professores e como devem ser utilizados no ensino concreto em sala de aula (Wilson, et al., 1987 apud García, 1995). Concluiu-se que, na investigação didática, não houve uma análise mais detalhada e profunda sobre o conhecimento que os professores têm dos conteúdos e do modo como estes conteúdos se transformam em ensino.

Para Shulman (1987),

"ensinar começa, necessariamente, com a compreensão do professor sobre o que deve ser aprendido e como deve ser ensinado (...); termina com uma nova compreensão do professor e do aluno. Embora esta seja, certamente, uma concepção central do ensino, é também uma concepção incompleta. Ensinar 
deve ser compreendido como sendo mais do que valorizar a compreensão” (Shulman, 1987, p.7).

Segundo este autor, o ponto central no seu conceito de ensino é o aluno aprender a entender e resolver problemas, aprender a pensar criticamente e criativamente, bem como os fatos de aprendizagem, princípios e regras de procedimento.

Como resultado de sua investigação, Shulman (1987) elaborou uma semântica do conhecimento em que se fundamenta o ensino, onde foram identificados diferentes tipos de conhecimento dos professores (já citados no item 3.1.2). O referido autor caracteriza o conjunto de conhecimentos docentes da seguinte forma:

1. Conhecimento do conteúdo da disciplina - refere-se ao domínio da área em que o professor é especialista; à compreensão da forma de pensar e entender como o conhecimento de sua disciplina é construído; à discussão e à organização do conteúdo específico.

2. Conhecimento pedagógico do conteúdo - está relacionado à forma particular como o professor transforma o conteúdo específico em atividade de ensino.

3. Conhecimento do currículo - trata-se do conhecimento sobre o conjunto de conteúdos a serem ensinados e dos materiais instrucionais referentes a eles.

4. Conhecimento pedagógico geral - refere-se aos conhecimentos dos princípios, objetivos e estratégias utilizadas pelo professor para a organização, desenvolvimento de sua disciplina e domínio da sala de aula, bem como o conhecimento de como o aluno aprende. Esse tipo de conhecimento transcende o domínio de uma área específica.

5. Conhecimento dos alunos e de suas características - refere-se ao conhecimento do desenvolvimento cognitivo e psicológico do aluno;

6. Conhecimento do contexto educacional - inclui as características da sala de aula, da escola, da comunidade e da cultura;

7. Conhecimento dos fins educacionais - é o conhecimento dos 
propósitos, valores e da base histórica e filosófica da educação

Pode-se perceber que em toda a base do conhecimento do professor existe a presença do conhecimento científico. Fato este, de importância relevante, se levado em consideração que o professor é o responsável pela tarefa de ensinar o conhecimento científico a seus alunos, além de outros saberes importantes para a formação geral dos mesmos.

Dos tipos identificados, Shulman aponta o conhecimento pedagógico do conteúdo como uma categoria importante no conjunto dos conhecimentos docentes, sendo o de maior interesse do ponto de vista didático, pois representa a combinação entre o conhecimento do conteúdo específico e o modo de ensiná-lo.

De acordo com o autor, há, pelo menos, quatro fontes principais para a base do conhecimento: 1 . conhecimento do conteúdo das disciplinas; 2. estruturas e materiais educacionais, por exemplo: currículo, livros, didáticos, organizações escolar e financeira e a estrutura da formação de professores; 3. conhecimento educacional formal, como: pesquisa escolar, organizações sociais, aprendizagem, ensino e desenvolvimento, e outro fenômeno cultural e social que afeta o que os professores podem fazer; 4. o saber da prática.

O autor reconheceu que o saber da prática é uma importante base do conhecimento de professores, mas também notou que muito desse conhecimento não é registrado. Considerou que surgiram certas dificuldades no acesso a esse conhecimento, pois os professores não têm audiência dos pares e um sistema de anotação para registrar a prática, ou seja, os professores desenvolvem atividades muitas vezes em sala de aula fechada e não têm um registro para avaliação entre os pares; sendo assim, a análise, a interpretação e a codificação dos princípios da prática são dificilmente recuperadas. Para o autor, o acesso ao saber da prática depende da distribuição de informações sobre o ensino, o que requer uma audiência dos pares com interesses similares e um sistema de anotação para registrar idéias e resultados sobre ela.

Porém, a reflexão também é necessária para aprender com a experiência. A reflexão é o que o professor faz quando ele "retorna" ao processo de ensino/aprendizagem que ocorreu e reconstrói e/ou recaptura os eventos, as emoções e os acontecimentos. É uma lista de processos através dos quais um profissional aprende com a experiência. 
Shulman propôs um modelo do raciocínio pedagógico do professor que retrata como os conhecimentos são acionados, relacionados e construídos durante o processo de ensino/aprendizagem. O seu modelo é composto por um ciclo de atividades de compreensão, transformação, instrução, avaliação, reflexão e novas compreensões que estão envolvidas no raciocínio pedagógico do professor, descritas a seguir:

1. Compreensão. Ponto de início e término do processo, pois ensinar é, primeiramente, compreender o que vai ser ensinado. Espera-se que o professor entenda o que será ensinado e, quando possível, entenda de várias maneiras. A compreensão dos propósitos também é central aqui. O professor ensina para atingir propósitos educacionais, finalidades que têm a ver com a aptidão literária do aluno, liberdade e responsabilidade do mesmo para desenvolver conhecimentos, habilidades e valores necessários para atuar em uma sociedade livre e justa. O professor também se esforça para equilibrar suas metas de encorajar a excelência individual com finalidades mais gerais, envolvendo igualdade entre alunos de diferentes formações culturais.

2. Transformação. A chave para distinguir a base do conhecimento do ensino está na intersecção de conteúdo específico e pedagogia, na capacidade do professor transformar o conhecimento do conteúdo, que ele possui, em formas que são pedagogicamente funcionais e adaptáveis às variações na habilidade e formação dos alunos. Esta fase se divide em quatro processos que resultam num conjunto de estratégias para representar uma lição, aula ou curso:

a) Preparação dos materiais: envolve a interpretação crítica dos materiais instrucionais. Nesse processo de preparação, o professor deve: analisar textos, verificando erros conceituais e de digitação; estruturar e segmentar o material em um formato que melhor se adapte à sua compreensão e ensino; desenvolver um repertório curricular e analisar propósitos e metas.

b) Representação das idéias: envolve pensar sobre as idéias 
chaves no texto e identificar formas alternativas de representação dos conceitos aos alunos, como: analogias, metáforas, exemplos, demonstrações, simulações, entre outras.

c) Seleção instrucional: nesse processo o professor cria um repertório instrucional de esquemas e estratégias de ensino, podendo incluir não somente palestras, demonstrações, trabalhos em sala de aula, mas também uma variedade de formas de ensino cooperativo, descobertas e projetos extra classe.

d) Adaptação: é o processo de adaptação do material às características do aluno. O professor adapta o material a tipos específicos de alunos em uma sala de aula, adapta representações não somente para alunos particulares, mas também para um grupo de alunos de tamanho, disposição e receptividade particulares. Também inclui aspectos relevantes de linguagem, cultura, motivação, conhecimento e habilidades dos alunos que afetarão na escolha das diferentes formas de representação e apresentação.

3. Instrução. Essa fase envolve muitos aspectos da pedagogia, do ato de ensinar, como: organizar e controlar a classe; apresentar explicações claras; propor e observar atividades; interagir com os alunos através de questões, provas, respostas e reações; elogiar e criticar, sendo que a compreensão que o professor tem sobre o conteúdo e a transformação do seu entendimento influencia o seu modo de ensino.

4. Avaliação. Inclui aspectos de checagem de entendimento e nãoentendimento que um professor precisa aplicar enquanto ensina, bem como avaliações formais para fornecer "feedback" aos alunos e atribuição de notas. Fazendo essa checagem, o professor faz uma realimentação (feedback) do seu próprio conhecimento, refazendo a sua compreensão e uma nova transformação, conduzindo-o a uma reflexão. 
5. Reflexão. É o que o professor faz quando analisa como o ensino e a aprendizagem ocorreram e reconstrói e/ou recaptura os eventos, as emoções. Será central para esse processo uma revisão do ensino em comparação aos fins a que se destina.

6. Nova Compreensão. Desse modo chegou a um novo começo, à expectativa de que, através de atos de ensino, alcança uma nova compreensão das propostas, dos assuntos a serem ensinados, dos alunos e dos processos pedagógicos propriamente ditos. A nova compreensão não ocorre automaticamente, mesmo depois da avaliação e reflexão. São necessárias estratégias específicas, documentação, análise e discussão, para promovê-la.

Segundo Shulman, a base do conhecimento para o ensino, as fontes para esse conhecimento e a complexidade do processo pedagógico conduzem a uma nova reforma no ensino. O modelo de Shulman será retomado mais adiante, como suporte teórico para a elaboração de uma metodologia para a formação de professores, na utilização e integração de tecnologias e na produção de material multimídia.

\subsection{Exemplos de Aplicação de Tecnologias na Formação de Professores}

Neste trabalho foi feito um levantamento das pesquisas, recentemente realizadas, que tratam da aplicação de tecnologias na formação inicial de professores. Como resultado, foram encontradas pesquisas realizadas no Brasil (Santa Catarina, Minas Gerais, Rio Grande do Norte, Mato Grosso do Sul e São Paulo), em Singapura e na Austrália. Algumas investigaram e discutiram o uso das tecnologias na formação de professores, como Dantas (2001), Lima (2001), Caligiorne (2002), Quartiero (2002), Santos (2002), Silveira (2002), Abranches (2003) e Mendonça (2003). Simião (2001) investigou o uso de softwares educacionais; Sharpe, et al. (2003) relatou o uso da videoconferência na prática de futuros professores, em Singapura. Questões sobre a Internet e cursos à distância, para a formação de professores, serão apresentadas nos itens $a$ e $b$ desta sessão. 
Em março de 2004, no I Seminário Internacional de Uso de Objetos de Aprendizagem, discutiu-se sobre os repositórios de conteúdos ou de objetos de aprendizagem e a importância de se formar professores com a visão de utilização de objetos de aprendizagem para o ensino presencial e à distância. Para tanto, foi feita uma breve introdução sobre objetos de aprendizagem e, no item $c$ desta sessão, relacionamos alguns trabalhos.

\section{a) Uso da Internet}

Dos trabalhos que estudaram o uso da Internet na formação de professores, Ferreira (2001) investigou o uso do computador e da Internet num curso de Licenciatura em Letras e propôs a pedagogia de projetos como metodologia para a inserção dessas novas tecnologias.

Quartiero e Catapan (2000) apresentaram uma homepage, como projeto de multimídia, discutindo a sua concepção pedagógica e técnica para a utilização em processos de aprendizagem no ambiente educacional e avaliando as possibilidades de interação via rede.

Jones (2002) usou a Internet, no curso de formação inicial de professores de uma universidade da Austrália, durante a disciplina "Learning Technologies in Education”. Nesse trabalho, observou-se que uma parte significativa, do grupo de futuros professores, não esteve confiante nas atividades básicas relacionadas à Internet (como leitura e envio de e-mail) e atividades na Web.

Pearson (1999) estudou o uso da Internet para facilitar a discussão entre os participantes de um curso de formação inicial de professores, na Austrália. O estudo revelou que não foi explorado o potencial dessa tecnologia, visto que os futuros mestres não desenvolveram uma audiência pública, idéias e práticas não tiveram registrado e comportamentos reflexivos não foram evidenciados. Houve dificuldades na apresentação dos conhecimentos dos futuros professores sobre ensino, através de e-mails, pelo fato de acharem que sua competência profissional fosse julgada por meio dessas mensagens.

\section{b) Cursos à distância}

Sobre as pesquisas com cursos de formação de professores à distância, Barros (2002) propôs a utilização de um ambiente virtual de aprendizagem para 
capacitar educadores na utilização de novas tecnologias em suas aulas.

Klaumann (2002) propôs um curso superior, à distância, na formação de docentes, com ênfase nas competências indispensáveis, para que os profissionais que atuam na educação básica desenvolvam, nos seus alunos, capacidades essenciais para a participação produtiva como cidadão.

Rocha (2001) realizou a análise de uma proposta para o desenvolvimento de um curso de graduação em Ensino de Física, à distância. Foram definidos os objetivos do curso, público-alvo, perfil dos professores do curso e fez-se uma discussão sobre a significância social, viabilidade econômica, infra-estrutura, apoio, avaliação, custos e resultados esperados deste curso.

Nevado (2001) ofereceu contribuições para a construção de conhecimento específico quanto à formação de professores, visando a introdução de tecnologias para facilitar processos interativos em EAD. A partir da análise dos resultados, viu-se a necessidade de buscar transformações qualitativas na aprendizagem, não transferindo simplesmente o modelo dos cursos clássicos para o formato hipermídia.

Mendes (2003) analisou um curso, à distância, de formação continuada de professores de Matemática, para o Ensino Fundamental, que usa a Internet na transmissão de conteúdo e como resolução interativa. Os resultados apontaram que os educadores investigados também tinham dificuldades em usar o e-mail para responder questões dissertativas, conforme identificado nos trabalhos australianos já apresentados de Jones (2002) e Pearson (1999).

\section{c) Objetos de Aprendizagem}

O avanço das tecnologias de informação e de comunicação tem acelerado o desenvolvimento da aprendizagem eletrônica (e-learning), possibilitando a utilização de conteúdos didáticos estruturados e mais organizados (Handa e Silva, 2003). Os objetos de aprendizagem (Learning Objects) surgem como um importante elemento para auxiliar no desenvolvimento de cursos eletrônicos e de material educacional digital, desde o seu planejamento até a disponibilização e atualização (Handa e Silva, 2003). A seguir serão apresentadas várias definições de objetos de aprendizagem: 
Para Beck (2001), objeto de aprendizagem é qualquer recurso digital que pode ser reutilizado no suporte ao ensino/aprendizagem. Segundo Coscarelli (2004), vídeos, imagens, figuras, gráficos e outros são disponibilizados para auxiliar na aprendizagem dos alunos.

O Learning Technology Standards Committee (LTSC) do Institute of Electrical and Electronics Engineers (IEEE), formado em 1996, para desenvolver e estabelecer padrões de tecnologia educacional, definiu objeto de aprendizagem como qualquer entidade, digital ou não-digital, que pode ser usada, reusada ou referenciada, durante o ensino, com suporte tecnológico. Exemplos de objetos de aprendizagem incluem conteúdo multimídia, conteúdos educacionais, objetivos de ensino, software educacional e software em geral e pessoas, organizações ou eventos referenciados durante um ensino com suporte tecnológico (Wiley, 2000).

Outras definições, como a do Instructional Management Systems (IMS) Global Learning Consortium - consórcio de especificações dos fabricantes de softwares educacionais -, são ainda mais técnicas e trabalham o conceito de objetos de aprendizagem dentro da teoria da orientação a objetos, utilizada no desenvolvimento de sistemas computacionais (Sosteric e Hesemeier, 2002). O objeto é definido como um conjunto de informações que contém rotinas e estruturas de dados que interagem com outros objetos. Na aprendizagem, o “objeto” serve para armazenar materiais digitais, transformando-os em módulos reutilizáveis e de fácil manipulação (Downes, 2001 apud Handa e Silva, 2003).

Uma aproximação teórica entre os objetos de aprendizagem e a orientação a objetos permite uma melhor organização do desenvolvimento de materiais de ensino, principalmente no âmbito tecnológico, facilitando também a definição de padrões para a interoperabilidade entre diversos objetos de aprendizagem desenvolvidos independentemente (Handa e Silva, 2003). No entanto, essa aproximação não finaliza a questão. Sosteric e Hesemeier (2001), em um artigo crítico sobre as diversas definições existentes, concluem que:

"um objeto de aprendizagem é um arquivo digital (imagem, filme, etc.) que pretende ser utilizado para fins pedagógicos e que possui, internamente ou através de associação, sugestões sobre o contexto apropriado para sua utilização.” 
Ainda que incompleta, segundo os autores, este seria um ponto de partida para uma definição real dos objetos de aprendizagem. Não é tão genérica como a apresentada pela IEEE e também não é tão técnica quanto a teoria de orientação a objetos, englobando-a, mas não limita o desenvolvimento de objetos de aprendizagem ao seu escopo, além de afirmar a necessidade de definição dos fins pedagógicos para um material educacional (Handa e Silva, 2003). A definição de Sosteric e Hesemeier (2001) se assemelha à definição de Beck (2001) e será assumida neste trabalho.

Questões como a produção em escala, diminuição do tempo de confecção, diminuição do custo e reutilização, além da melhor organização do processo de criação, são relevantes e justificam a implementação e uso dos objetos de aprendizagem (Handa e Silva, 2003).

Para a educadora Martha Stone Wiske, da Escola de Graduação em Educação de Harvard e responsável pelo projeto Teaching for Understanding with New Technology ${ }^{16}$, é fundamental que os objetos de aprendizagem tenham um objetivo claro para os alunos e que o professor faça uma avaliação contínua do processo (MEC, 2004):

"Não adianta apenas criar objetos de aprendizagem e torná-los disponíveis. Eles têm de fazer parte do dia-a-dia do aluno e do professor”

\section{Projetos que utilizam objetos de aprendizagem}

A prática tem redefinido o conceito de objetos de aprendizagem, pois as iniciativas que os adotam acabam adaptando seu uso à sua realidade (Handa e Silva, 2003). Certos projetos no Brasil estão utilizando objetos de aprendizagem no seu contexto, podendo citar a Escola do Futuro com o projeto LabVirt e a Rede Internacional Virtual de Educação (RIVED), um programa do Ministério de Educação e Cultura (MEC).

\section{- LabVirt $^{17}$}

\footnotetext{
${ }^{16} \mathrm{http}: / /$ learnweb.harvard.edu/ent/home/index.cfm

${ }^{17}$ http://www.labvirt.futuro.usp.br
} 
O LabVirt é uma proposta pedagógica, onde professores de Física do Ensino Médio trabalham conceitos em classe e estimulam seus alunos a prepararem a “encomenda” de uma simulação. Essa “encomenda” explicita o conceito, apresenta uma história ou situação, define as equações envolvidas e acrescenta detalhes pertinentes. O LabVirt recebe a "encomenda", pede os dados complementares necessários e prepara a simulação (por exemplo: uma corrida de automóveis, dois trapezistas em ação, etc.) que é colocada no site do projeto. Para dar seqüência ao desenvolvimento do LabVirt, pretende-se aumentar o número de escolas conveniadas e ampliar o trabalho para as áreas de Química e Biologia, na expectativa de que o efeito demonstração faça com que outras instituições de ensino superior criem programas semelhantes (Telles, 2004).

- $R I V E D^{18}$

O RIVED é um projeto de cooperação internacional entre países da América Latina, onde, atualmente, trabalham de forma colaborativa, Brasil, Peru e Venezuela. No Brasil, o projeto é desenvolvido pelo MEC, através das Secretaria de Educação à Distância (SEED) e Secretaria de Educação Média e Tecnológica (SEMTEC). O programa envolve a produção de material pedagógico multimídia, a capacitação de pessoal e sua distribuição na rede. O RIVED utiliza a tecnologia de objetos de aprendizagem na produção de seus módulos a fim de otimizar a produção e possibilitar a sua escalabilidade e reutilização ${ }^{19}$.

A primeira fase do projeto foi encerrada no final de 2003, onde um grupo de 10 pessoas desenvolveu 20 módulos educacionais (material didático digital adaptado à grade curricular) voltados ao ensino das Ciências da natureza e da Matemática no Ensino Médio público. Segundo Américo Bernardes, diretor-geral do Programa Nacional de Informática na Educação (ProInfo), a partir de 2004, mais 12 equipes, formadas por alunos e professores de ensino superior, serão incorporadas à rede, num programa chamado de Fábrica Virtual (MEC, 2004).

\footnotetext{
${ }^{18}$ http://rived.proinfo.mec.gov.br

${ }^{19}$ http://rived.proinfo.mec.gov.br/projeto.htm
} 


\subsection{Considerações Finais}

Nos exemplos citados de aplicação de tecnologias na formação de professores, a maior parte das pesquisas verifica quais recursos tecnológicos estão sendo utilizados e de que modo. Isso tem suma importância, visto que as propostas de integração de tecnologias na formação inicial de professores utilizam softwares educacionais, aplicativos e alguns recursos da Internet. A maioria utiliza um editor de texto e os recursos de pesquisa e e-mail da Internet, como Lima (2001) que identificou que a Internet foi usada, em 76 cursos de Licenciatura do Estado de Santa Catarina, principalmente como ferramenta de pesquisa. Isso pode ocorrer por falta de conhecimento de outras tecnologias e, às vezes, por falta de treinamento.

Nesses exemplos, certos aspectos são destacados: Caligiorne (2002) conclui que os professores devem ter a chance de poder compreender com a própria prática e transformá-la; Dantas (2001) destaca a necessidade de preparar os professores para a utilização pedagógica das tecnologias, mostrando que cada uma tem características particulares, exigindo um profissional capaz de saber quando, onde, porque e para que utilizá-las; Simião (2001) verifica que o uso do software educacional, por si só, não garante um ensino adequado, porém, é um aspecto relevante no ensino, o domínio do conteúdo específico e o tipo de utilização pedagógica da ferramenta pelo docente; Sharpe, et al. (2003) relatam que o uso de videoconferência na formação inicial de professores em Singapura, ajudou a melhorar o desenvolvimento desses profissionais, permitindo a distribuição de idéias, experiências e recursos de ensino em tempo real, além de oferecer-lhes oportunidades de visualizarem os vídeos da sua prática de ensino e receber feedback dos pares e supervisores universitários.

Não se encontrou uma proposta de orientação do futuro professor em como usar tecnologias em suas aulas, visando, inclusive, a obtenção de mídias para a produção de material educacional digital. A percepção da inexistência de proposta, aliada à sua importância na área educacional e levando-se em consideração os aspectos levantados pelos pesquisadores acima, deu motivação para o desenvolvimento deste trabalho.

Inicialmente, procurou-se estudar o uso de outras tecnologias como o 
vídeo, áudio e Mimio, ou lousa eletrônica, na formação inicial de professores; identificar as expectativas dos futuros professores com relação ao uso dessas tecnologias, levantando, com isso, os requisitos de seu uso em curso de formação inicial de professores.

Portanto, fez-se um estudo, no ano de 2002, no curso de Licenciatura em Ciências Exatas da USP/São Carlos, sobre a aplicação de tecnologias em sala de aula e a sua análise (item 5.2). Após esse estudo, viu-se a necessidade de se instituir uma metodologia para a formação inicial de professores no uso de tecnologias, ou seja, para os futuros professores as usarem em sala de aula e integrarem informações em um produto multimídia. Antes do uso desse tipo de integração, os futuros professores a realizavam por meio de páginas HTML com links para diversas mídias, conforme descrito no item 5.2.2, o que dificultava o processo, pois exigia maior conhecimento de informática por parte dos licenciandos: o usuário precisava selecionar um link para visualizar a mídia correspondente, não havendo sincronização entre elas. Dessa forma, a integração por meio de links em páginas HTML para as mídias não possibilitava o acesso e a visualização das mesmas em um único produto e ao mesmo tempo.

Este trabalho pode ser inserido no contexto de objetos de aprendizagem pois, além de servir como repositório para futuras inclusões digitais, permitindo que o material educacional multimídia produzido possa ser reutilizado em cursos à distância ou presenciais, o vídeo, o áudio, o texto, a foto, dentre outros (considerados objeto de aprendizagem) podem ser reutilizados na produção de outros materiais multimídia.

Apesar deste trabalho ter como foco a formação inicial de professores, também pode ser aplicado na formação continuada e com professores da ativa, para o incentivo ao uso de tecnologias em sala de aula. 


\section{A Metodologia Proposta}

\subsection{Considerações Iniciais}

Muitos são os benefícios da tecnologia aplicada na educação e os alunos demonstram estar dispostos a aprender conteúdos utilizando-se desses recursos. De acordo com Simião e Reali (2002), auxiliar os professores a aprender a ensinar com o uso da tecnologia de maneira eficiente, pode ser o passo mais importante para garantir que o computador possa contribuir na melhoria da qualidade de ensino.

Segundo a análise de Orth (1996), formar professores capazes de integrar o computador na sua proposta educacional, seja qual for o paradigma de ensino/aprendizagem usado, é urgente e inadiável, por isso, propostas concretas, objetivas, factíveis e abrangentes devem ser discutidas e implementadas.

Nessa perspectiva, o amplo acesso e uso de tecnologias condicionam à reorganização dos currículos, dos modos de gestão e das metodologias utilizadas na prática educacional (Kenski, 2003). Neste trabalho, estamos propondo que a metodologia, desenvolvida para orientar professores no uso de tecnologias no ambiente educacional, seja usada como uma nova metodologia de ensino. A necessidade de instituí-la surgiu após experiência com aplicação de tecnologias na formação inicial de professores (Magalhães e Schiel, 2003), descrita no item 5.2.

Na literatura pesquisada sobre aplicação de tecnologias na formação 
inicial de professores no Brasil e em outros países, encontraram-se trabalhos sobre a utilização de softwares educacionais pelos futuros professores (Simião, 2001), a discussão teórica sobre o uso de computadores (Dantas, 2001; Caligiorne, 2002; Santos, 2002), a utilização de recursos da Internet nos cursos de Licenciatura (Pearson, 1999; Quartiero e Catapan, 2000; Ferreira, 2001; Lima, 2001; Jones, 2002) e encontraram-se estudos relacionados sobre cursos à distância de formação inicial de professores (Klaumann, 2002; Rocha, 2001). Não foram encontrados estudos, com a utilização de outras tecnologias, em cursos para futuros professores, como lousa eletrônica, nem mesmo a elaboração de material educacional digital para ser aplicado com alunos.

Este trabalho propõe uma metodologia a ser aplicada na formação inicial de professores, para orientá-los na incorporação de tecnologias em suas aulas, de forma que possam produzir seus materiais educacionais multimídia. O material produzido pode conter diversos tipos de mídias, como slides, textos, fotos, vídeo e áudio de uma aula já ministrada, além das informações escritas pelo professor na lousa em conjunto com o áudio, obtidos com os recursos da tecnologia Mimio. O aluno pode visualizar esse material em CD-ROM ou via Internet.

Do ponto de vista educacional, em que a integração irá ajudar? O material multimídia produzido na integração das mídias, a partir da captura das aulas ministradas, serve para:

- a reflexão do professor sobre a sua prática docente;

- a revisão do aluno, possuindo uma segunda oportunidade de entrar em contato com o contexto de uma aula dada em seus detalhes;

- a sua utilização com alunos com necessidades especiais, usufruindo dos recursos que a própria multimídia oferece, como por exemplo, os deficientes auditivos que podem utilizar o mesmo material contendo a transcrição do áudio;

- o seu uso como material de cursos à distância ou em ambientes virtuais.

Por que é importante esta metodologia e em que contribui para a formação de professores? A metodologia proposta fornece possibilidade de uso de 
tecnologias, as quais dariam suporte inicial para o professor começar a utilizá-las em sala de aula, integrando as mídias para a produção de material educacional digital e, depois de uma experiência maior com esta metodologia, o professor poderia buscar outras alternativas de aplicação e integração de tecnologias.

\subsection{Fases da Metodologia Proposta}

Retomando o conceito de Vermelho, et al. (1998) sobre a divisão em fases, do processo de incorporação de tecnologias no trabalho do professor, pode-se observar que, para o processo se dar efetivamente, seu início deve ocorrer no contato do professor com as tecnologias, de uma forma voltada para o seu cotidiano. Assumindo essa posição, a fim de que o uso da tecnologia não seja limitado, usufruindo dos recursos que ela pode oferecer e levando em consideração a teoria hierárquica de integração de tecnologias de Rieber e Welliver (1989) (item 2.3) e o modelo sobre o raciocínio do professor de Shulman (1987) (item 3.2), propomos a divisão da metodologia em quatro fases: Preparação, Produção, Integração e Visualização/Distribuição (figura 6). 


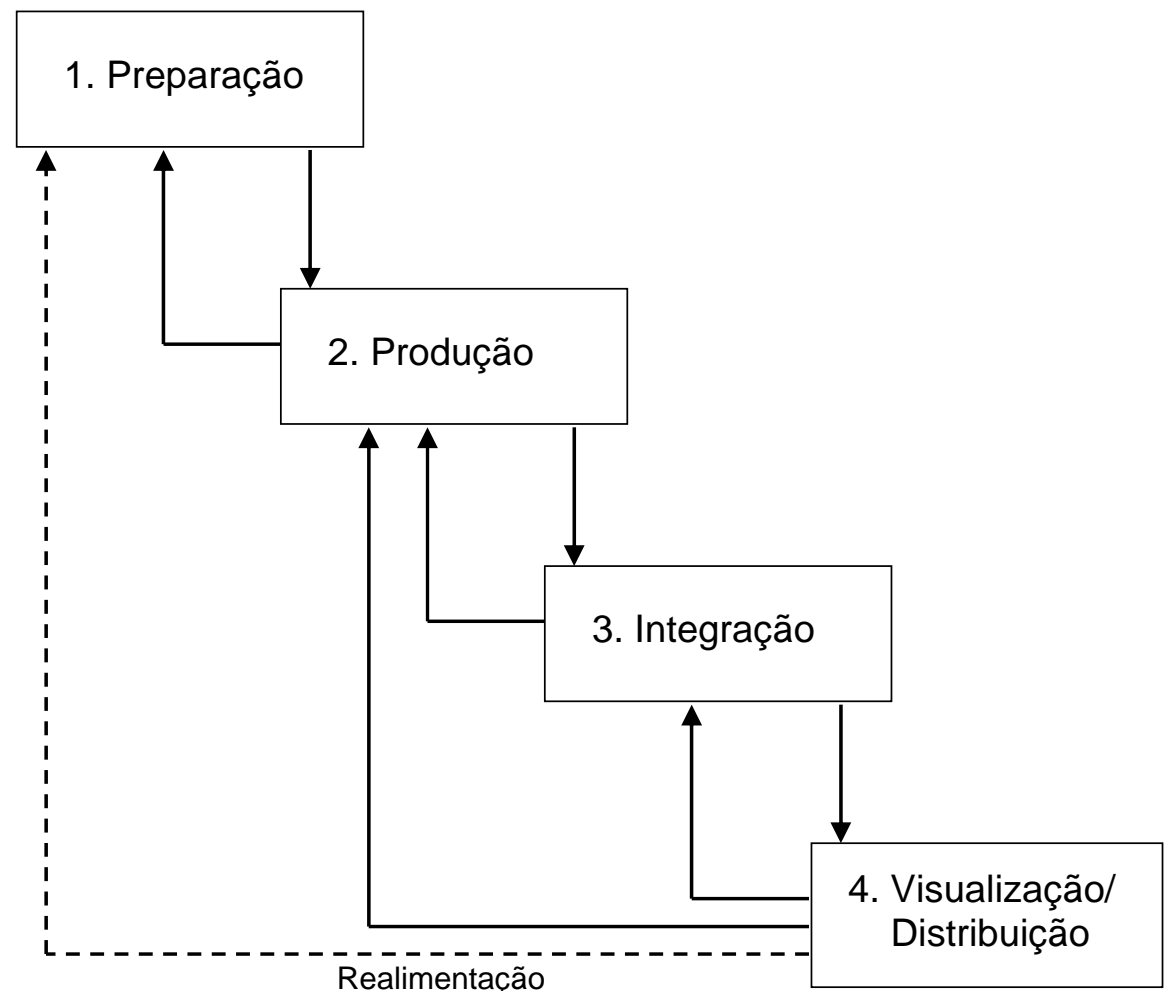

Figura 6 - Fases da metodologia para integração de novas tecnologias na formação de professores.

1. Preparação: Essa fase, que ocorre antes da aula, consiste em conhecer as tecnologias disponíveis para uso, saber qual utilizar em função do conteúdo, planejar o conteúdo a ser abordado em sala de aula e transformá-lo em formas compreensíveis aos alunos.

2. Produção: Durante uma aula, são obtidas informações por meio de diversas fontes de mídia, como câmera de vídeo, microfone, Mimio, dentre outras. Após a aula, pode-se editar as mídias nela obtidas em sala de aula e, se necessário, o professor pode retornar para a fase de Preparação.

3. Integração: Essa fase consiste na integração das mídias obtidas, o que pode ser feito por meio da linguagem SMIL. Para não técnicos em informática, será apresentado no item 4.2.3.1 um software desenvolvido para realizar esta tarefa.

4. Visualização/Distribuição: É nessa fase que será visualizado o material produzido da integração das mídias. Dessa forma, pode-se 
verificar como está o material e se é necessário retomar as fases anteriores. Para a sua distribuição, pode ser feita a gravação em CDROM ou disponibilização em um servidor Real para o material ser acessado via Internet.

A teoria hierárquica de integração de tecnologias de Rieber e Welliver (1989) e o modelo sobre o raciocínio do professor, proposto por Shulman (1987), ofereceram suporte teórico para a elaboração da metodologia aqui proposta, conforme Tabela I.

Tabela I - Suporte teórico oferecido pela teoria de Rieber e Welliver (1989) e pelo modelo de Shulman (1987) para a metodologia proposta.

\begin{tabular}{|c|c|c|}
\hline $\begin{array}{c}\text { Teoria Hierárquica de } \\
\text { Integração de Tecnologias de } \\
\text { Rieber; Welliver (1989) }\end{array}$ & Metodologia proposta & $\begin{array}{c}\text { Modelo do Raciocínio do } \\
\text { Professor de Shulman } \\
\text { (1987) }\end{array}$ \\
\hline $\begin{array}{l}\text { 1. Familiarização - } \\
\text { 2. Utilização }\end{array}$ & $\begin{array}{l}\text { 1. Preparação } \\
\longrightarrow \text { - Conhecimento das tecnologias } \\
\text { disponíveis } \\
\text { - Reflexão sobre o uso das } \\
\text { tecnologias } \\
\text { - Planejamento do conteúdo } \\
\text { - Transformação do conteúdo em } \\
\text { formas compreensíveis aos } \\
\text { alunos } \\
\text { 2. Produção } \\
\text { - Captura da informação } \\
\text { - Edição das mídias } \\
\text { 3. Integração } \\
\text { 4. Visualização / Distribuição }\end{array}$ & $\begin{array}{l}\text { 1. Compreensão } \\
\text { 2. Transformação }\end{array}$ \\
\hline $\begin{array}{l}\text { 3. Integração } \\
\text { 4. Reorientação } \\
\text { 5. Evolução }\end{array}$ & $\begin{array}{l}\text { Aplicação do material multimídia } \\
\text { com os alunos em sala de aula. }\end{array}$ & $\begin{array}{l}\text { 3. Instrução } \\
\text { 4. Avaliação } \\
\text { 5. Reflexão } \\
\text { 6. Nova Compreensão }\end{array}$ \\
\hline
\end{tabular}

O processo de Conhecimento das tecnologias disponíveis da fase de Preparação da metodologia aqui proposta, se relaciona com as fases de Familiarização e de Utilização da teoria hierárquica de integração de tecnologias, onde os professores se informam sobre as tecnologias disponíveis em seu ambiente de trabalho e aprendem a utilizá-las. 
No processo de Reflexão sobre o uso das tecnologias da fase de Preparação será levantada a opinião do professor, na visão de aluno, sobre o uso e funcionalidades das tecnologias. Esse processo não se assemelha à fase de Reflexão do modelo sobre o raciocínio do professor, proposto por Shulman, pois esse último, ocorre após a aplicação de tecnologias em sala de aula e sua avaliação pelo professor.

As fases de Compreensão e de Transformação do modelo de Shulman, ofereceram suporte teórico nos processos de Planejamento do conteúdo e de Transformação do conteúdo em formas compreensíveis aos alunos da fase de Preparação da metodologia proposta.

Na fase de Compreensão espera-se que o professor compreenda o que vai ser ensinado de diferentes maneiras, sabendo relacionar um conteúdo específico com outras idéias dentro da mesma área a outros assuntos de áreas distintas. Já a fase de Transformação é tida como a etapa central do processo e explica que o professor deve perceber que o ensino é marcado pelo seu conhecimento e do aluno e que deve transformar o conhecimento do conteúdo que possui, em formas que sejam compreensíveis aos alunos.

Nesse contexto, nos dois processos da fase de Preparação citados acima, o professor precisa conhecer o conteúdo que será apresentado, fazendo um planejamento das atividades para a aula, que envolvam alguma mídia, e não apenas lápis e papel.

Como a metodologia propõe a produção de material educacional multimídia a partir das informações obtidas antes e/ou durante a aula, foi elaborada a fase de Produção contendo os processos de Captura da Informação e de Edição de Mídias.

Nessa metodologia, a chamada "fase de Integração" não coincide exatamente com a fase de Integração da teoria de Rieber e Welliver, pois essa última, refere-se ao momento em que os professores começam a integrar a tecnologia no currículo, o que já vem ocorrendo na metodologia proposta desde a fase de Produção. Já na "fase de Integração" desta metodologia, propomos o uso de software para integrar as informações obtidas na fase de Produção.

$\mathrm{Na}$ fase de Visualização/Distribuição da metodologia proposta, o professor visualiza e aprova o material multimídia produzido, verifica se há necessidade de retornar às fases anteriores, a fim de usar tecnologias para readequar 
o material e escolher se o mesmo será distribuído via Internet ou em CD-ROM para depois aplicar com seus alunos.

As fases de Integração, Reorientação e Evolução da teoria de Rieber e Welliver e as fases de Instrução, Avaliação, Reflexão e Nova Compreensão do modelo de Shulman, ocorrem durante e/ou após a aplicação de tecnologias com os alunos em sala de aula, onde o professor pode adquirir novas responsabilidades, se tornando um facilitador no uso de tecnologias; pode avaliar e refletir sobre suas aulas com tecnologias, procurando conhecer novos recursos tecnológicos para serem aplicados em suas aulas; pode se tornar um administrador da tecnologia, avaliando novos recursos tecnológicos e novas habilidades necessárias para usá-los.

A metodologia proposta dá destaque às fases que precedem à aplicação de material multimídia em sala de aula, orientando o professor, não apenas no uso de tecnologias, mas também, na elaboração deste material educacional. Nos itens a seguir, serão descritos detalhamentos das fases da proposta metodológica deste trabalho.

\subsubsection{Fase de Preparação}

A fase de Preparação da metodologia proposta contém vários processos. São eles: Conhecimento das tecnologias disponíveis, Reflexão sobre o uso das tecnologias, Planejamento do conteúdo e Transformação do conteúdo em formas compreensíveis aos alunos.

Antes da aula, o professor tomará conhecimento das tecnologias disponíveis para utilização em sala de aula, deverá realizar uma atividade-reflexão (item 5.3), escolher os recursos tecnológicos adequados ao conteúdo, preparar o conteúdo a ser apresentado e transformar o conhecimento do conteúdo em formas compreensíveis aos alunos.

\section{a) Conhecimento das tecnologias disponíveis}

Segundo Leite (1996), o conhecimento das tecnologias educacionais disponíveis é fundamental para o professor realizar um trabalho pedagógico transformador e de qualidade. 
Cabe à equipe da escola (professores, coordenadores pedagógicos, diretores) a decisão sobre qual o meio tecnológico ou quais as mídias mais adequadas para o ensino, a fim de alcançar os objetivos previstos (Kenski, 2003). Para isso, é preciso obter informações sobre os equipamentos disponíveis na instituição para serem utilizados no ensino e realizar a análise de suas possibilidades e conveniência de uso no processo pedagógico (Kenski, 2003). Seria importante que a escola tivesse um Projeto Pedagógico estruturado, no qual estivesse prevista a utilização de tecnologias.

Portanto, nesta fase, é necessário que o professor conheça as tecnologias disponíveis em sua escola para que saiba quais poderá utilizar e como deverá fazê-lo. Independente de o professor atuar em uma escola com maior ou menor quantidade de tecnologias, Leite (1996) ressalta que o alcance de cada uma delas está, em geral, no fato do professor dominá-las e na sua criatividade quanto às suas formas de utilização.

\section{b) Reflexão sobre o uso das tecnologias}

Este processo envolve a realização de uma atividade que procurou despertar aspectos reflexivos no futuro professor. Neste trabalho chamaremos, brevemente, esta atividade, de atividade-reflexão ${ }^{20}$, onde o professor irá visualizar materiais multimídia e, na visão de aluno, irá analisar e refletir sobre a função de cada mídia. Após a análise, o professor irá verificar qual tecnologia poderá ser empregada em sua aula e para que irá usá-la. Esta atividade visa oferecer oportunidade para o professor explorar diversas tecnologias, analisar e refletir suas potencialidades, do ponto de vista da aprendizagem, tendo sua opinião, como aluno, sobre as tecnologias, que lhe darão condições de escolher a tecnologia ideal para apresentar um determinado conteúdo.

\section{c) Planejamento e transformação do conteúdo}

Segundo Kenski (2003), é preciso considerar que as tecnologias condicionam os princípios, a organização e as práticas educativas e impõem profundas mudanças na maneira de organizar os conteúdos a serem ensinados, as

\footnotetext{
${ }^{20}$ Ver exemplo da atividade no Anexo D.
} 
formas como serão trabalhadas e acessadas as fontes de informação e os modos individuais e coletivos, como irá ocorrer a aprendizagem.

De acordo com Reed (2003), em muitas escolas nos Estados Unidos os professores estão aprendendo a preparar planos de aulas e atividades para os alunos no formato de áudio, vídeo, gráfico e texto impresso, com a finalidade de disponibilizar diversos caminhos de obtenção do conteúdo.

Nesse processo, é válido lembrar as fases, já apresentadas, de Compreensão e de Transformação do modelo do raciocínio do professor (Shulman, 1987). A metodologia proposta neste trabalho, trata desse assunto nos processos de Planejamento do conteúdo e de Transformação do conhecimento do conteúdo, onde o professor deve preparar o material, representar as idéias utilizando novas formas para explicar o conteúdo, selecionar os métodos de trabalho e adaptá-los às características gerais dos alunos. Após essas etapas, o professor vai possuir recursos para perceber que o ensino deve levar em conta o seu próprio conhecimento e o conhecimento do aluno até aquele momento.

Portanto, neste processo, o professor precisa planejar o conteúdo que será apresentado, ou seja, fará o planejamento das atividades da aula. Segundo Perrenoud (1997), o planejamento das atividades é essencial para o professor avançar no programa anual e para manter a ordem, assegurando um funcionamento do grupo favorável à comunicação e ao trabalho. Shulman (1987) afirma que o planejamento do professor baseia-se, particularmente, no que ele sabe, no que ele conhece do assunto; influencia também na escolha do tipo de aula (expositiva, trabalho em grupos, etc.), no texto e exercícios selecionados, e, especialmente, na maneira como ele, o professor, interage com seus alunos.

Na metodologia proposta, esta é uma etapa muito importante e precisa de um certo tempo de dedicação do professor para estabelecer o material que será apresentado aos alunos. Pois, de acordo com Kenski (2003), o uso da tecnologia no ensino implica em uma nova administração do tempo do professor, sendo dedicado um tempo maior para o planejamento das atividades em sala de aula.

Uma vez definido o material, seria interessante o professor delinear uma proposta de trabalho destacando os pontos principais e prevendo em quais situações os alunos usarão o material multimídia a ser criado por ele na fase de Integração da metodologia aqui proposta. A questão principal nesta etapa é mostrar o que é 
essencial para o processo de ensino/aprendizagem.

\subsubsection{Fase de Produção}

A fase de Produção consiste em capturar a informação e editar as mídias. Esses processos ocorrem em diferentes estágios do trabalho docente: durante a aula e após a aula, respectivamente. Durante a aula, o professor poderá capturar a informação em diversos formatos de mídia (como vídeo, áudio). E após a aula, o professor poderá fazer a edição dessas mídias. A seguir serão descritos estes processos.

\section{a) Captura da Informação}

Em uma aula, o professor pode usufruir do auxílio de vários recursos. Pode utilizar o quadro negro para escrever, um retro-projetor para exibir as informações contidas em transparências impressas ou um projetor multimídia conectado a um computador para exibir as informações contidas nos slides que estão em arquivo.

Com o conhecimento das tecnologias disponíveis e com o planejamento do conteúdo, o professor tem em mente o que será aplicado em sala de aula, qual a finalidade do material a ser produzido e como ele será transformado em formas compreensíveis aos alunos. A partir daí, o professor irá obter as informações em sala de aula por meio das mídias escolhidas durante o processo de Captura da Informação. Portanto, será necessário escolher o meio pelo qual o conteúdo será exibido. Algumas hipóteses de utilização de conteúdo são descritas a seguir:

1. O professor pode preparar slides do PowerPoint e gravar um vídeo e áudio da aula;

2. Pode utilizar uma foto do professor e o áudio obtido durante a aula;

3. Se for utilizar a lousa branca, sugere-se a utilização do Mimio com o boardCast ${ }^{21}$ para capturar as anotações do professor na lousa em sincronia com o áudio e a utilização de uma foto do professor;

\footnotetext{
${ }^{21}$ Ver Apêndice I, para mais informações.
} 
4. O professor pode capturar apenas as informações da lousa sem o áudio e, ao invés de utilizar uma foto sua, pode gravar um vídeo durante a aula;

5. Em uma aula prática, como por exemplo sobre o uso de um determinado software, seria interessante utilizar um projetor multimídia para exibir as etapas do software aos alunos. Durante essa aula, essas etapas poderiam ser filmadas para, posteriormente, serem integradas no lugar das informações da lousa capturadas pelo Mimio. Porém, esse vídeo deve ter boa qualidade de resolução e o áudio deve ter o mínimo de ruído possível. De acordo com Magalhães e Schiel (2004), o professor deve falar pausadamente, mostrando o software como se estivesse escrevendo em uma lousa, para que o aluno, posteriormente, possa acompanhar.

\section{Capturando as Informações da Lousa}

Com a utilização de uma lousa eletrônica, tornou-se possível armazenar o que está sendo escrito sobre ela durante uma aula, sem que o aluno necessite fazer essas anotações. Com isso, o aluno teria mais tempo para prestar atenção na aula, entender o material preparado e se engajar em discussão de tópicos importantes.

Se o professor tiver acesso ao Mimio, ele poderá obter as informações da lousa capturadas e salvas em HTML - informações estáticas - ou salvas durante a aula com o boardCast do software Mimio - informações dinâmicas.

\section{Obtendo o Áudio 22}

O áudio pode ser obtido a partir de um vídeo já gravado ou diretamente de um microfone e o ideal seria um microfone de lapela para o professor se locomover livremente. Porém, isso fica a seu critério e do que tem disponível para uso.

O boardCast do software do Mimio é outra opção para se obter o áudio. Se o professor tiver acesso a um computador com o boardCast instalado, pode-se também obter o áudio gravado durante a aula e, se utilizar a lousa e obter as 
informações gravadas dinamicamente, irá obter o áudio em sincronia com as mesmas.

\section{Capturando o Vídeo ${ }^{23}$}

Uma das vantagens do vídeo é a possibilidade de ser revisto (Schön, 1995) podendo ser usado para a reflexão do professor e para o ensino aos alunos. Schön (1995) afirma que é preciso chegar ao que os professores fazem através da observação direta e registrada, pois permite uma descrição detalhada do comportamento e uma reconstrução das intenções, estratégias e pressupostos. Segundo o autor, o confronto com esses dados diretamente observáveis produz, muitas vezes, um choque emocional, à medida que os professores vão descobrindo que atuam segundo teorias de ação diferentes daquelas que professam.

A produção de conteúdo de vídeo não deve mais ser considerada como uma atividade custosa, em termos financeiros e de tempo envolvido pois, segundo Strom (2002), ferramentas de captura e de geração de conteúdo estão se tornando mais acessíveis para usuários não técnicos em informática, eliminando a dependência de especialistas em mídia e permitindo maior autonomia no processo de produção, particularmente em termos de introdução direta do pensamento pedagógico. Isso, porém, não dispensa um treinamento mínimo no uso dessas ferramentas.

\section{b) Edição das Mídias}

Após a aula, o professor precisa ter um software para a edição das mídias obtidas, como o áudio e/ou vídeo. As informações capturadas pelo software do Mimio e os slides não precisam de edição. Para a edição de vídeo pode ser utilizado o Adobe Premiere, que possui opção de exportação para MPEG (extensão MPG) e RealMedia (extensão RM), o software freeware Vídeo Framer, dentre outros. Para a edição de fotos e imagens pode-se utilizar o Adobe PhotoShop, o Microsoft Paint, etc.

${ }^{22}$ Detalhes técnicos sobre a produção de áudio, ver o RealNetworks Production Guide em http://service.real.com/help/library/guides/realone/ProductionGuide/HTML/htmfiles/audio.htm\#34361 ${ }^{23}$ Detalhes técnicos sobre a produção de vídeo, ver o RealNetworks Production Guide, em http://service.real.com/help/library/guides/realone/ProductionGuide/HTML/htmfiles/video.htm\#29959 


\subsubsection{Fase de Integração}

Foi realizado um estudo de quais tecnologias poderiam ser utilizadas para que as mídias capturadas em sala de aula ou preparadas anterior ou posteriormente à aula, fossem integradas de uma forma fácil e simples. Desse estudo, viu-se que a linguagem SMIL é adequada para esse processo, pois é uma linguagem baseada em XML que permite a integração multimídia sincronizada, especificada em documentos. Esses documentos, ao serem reproduzidos com o RealOne Player, por exemplo, geram apresentações multimídia. A reprodução de documentos pode ser considerada uma apresentação multimídia porque envolve mídias contínuas (áudio e vídeo) e discretas (texto e imagem) que interagem entre si; essa interação é, na verdade, a sincronização entre as mídias, essencial para uma apresentação multimídia (Cattelan, et al. 2003).

A fase de Integração da metodologia proposta consiste em integrar as mídias obtidas nos processos da fase de Produção e pode ser realizada utilizando a linguagem SMIL. Para elaborar um documento SMIL, é suficiente apenas um editor de texto, porém, o usuário desenvolvedor deve ter conhecimentos da linguagem, o que pode ser uma barreira na aplicação dessa tecnologia. Entretanto, outra alternativa é utilizar softwares desenvolvidos para gerar apresentações multimídia, sem que o usuário seja um especialista em informática. Segundo White, et al. (2002), grande parte desses softwares tem custos de aquisição elevados e outros são gratuitos, porém possuem certas restrições, como tempo de duração de uma apresentação.

Portanto, para a realização dessa fase, foi desenvolvido um software para Integração Sincronizada de Mídias (InMid) (item 4.2.3.1), com o objetivo de ser um software simples, fácil de usar e que atenda as necessidades do usuário desenvolvedor não especialista em informática, nesse caso o professor. Porém, nada impede que seja utilizado outro software (White, et al., 2002) durante a fase de Integração.

É importante para o professor entender que há basicamente três categorias de softwares (Kuechler, 2000) na área de multimídia sincronizada:

Ferramentas de Produção/Edição "Production/Edition Tools" Softwares que auxiliam o professor a produzir, capturar ou editar diversas mídias 
como áudio e vídeo. Exemplos: software do Mimio, Adobe Premiere, Adobe PhotoShop.

Ferramentas de Servidor "Server Tools" - Softwares especiais que trabalham em conjunto e residem em um servidor. Como somente o administrador do sistema computacional manuseia esses softwares, não é preciso o professor entender do seu funcionamento, porém, são necessários para a distribuição do material multimídia e para uma melhor performance. Exemplo: RealServer.

Ferramentas de Visualização "Players Tools" - Softwares que trabalham com o Browser e permitem que o usuário visualize os arquivos gerados pelas Ferramentas de Produção. Exemplo: RealOne Player.

Essas categorias interagem entre si, não sendo necessário o professor conhecer todos os softwares pertencentes a elas, nem mesmo ser usuário de todos eles. Atualmente, existem softwares que não se enquadram dentro das categorias propostas por Kuechler (2000), os quais são utilizados para a integração de mídias. Para tanto, sugerimos uma nova categoria de software para conhecimento do professor, intitulada "Ferramentas de Integração de Mídias” e definida a seguir:

Ferramentas de Integração de Mídias “Media Integration Tools” Softwares que permitem a integração de áudio, vídeo, texto, imagem, ou seja, das mídias obtidas pelas Ferramentas de Produção/Edição. Exemplo: SMIL Scenario Creator, Microsoft Producer.

Este trabalho traz uma contribuição nova para essa categoria, que é o software InMid, proposto e desenvolvido juntamente com a metodologia e apresentado no item seguinte. Também sugere uma alteração na definição das Ferramentas de Visualização, ficando da seguinte maneira:

Ferramentas de Visualização "Players Tools” - Softwares que podem trabalhar em conjunto com o Browser e permitem que o usuário visualize os arquivos gerados pelas Ferramentas de Produção e pelas Ferramentas de Integração de Mídias. Exemplo: RealOne Player.

\subsubsection{O Software InMid}

Baseado na experiência de aplicação de tecnologias em sala de aula 
realizada em 2002 (Magalhães e Schiel, 2003) (item 5.2) e em pesquisa de softwares existentes para integração de mídias (White, et al., 2002), foi desenvolvido o software InMid, que é um Media Integration Tool e se enquadra na nova categoria de software definida anteriormente. Foto, vídeo, slides, animação em Flash, áudio, textos e arquivos obtidos pelo software do Mimio, podem ser integrados e sincronizados pelo professor, através do InMid. Links para a Internet também podem ser integrados utilizando os "Itens de Menu” gerados pelo software. O material produzido a partir dessa integração poderá ser utilizado para a reflexão do professor e para a revisão do aluno.

A proposta do InMid é a de facilitar a integração das informações obtidas antes da aula (como os slides em PowerPoint), durante a aula (como informações da lousa, vídeo e áudio) e materiais complementares à aula (como links para sites na Internet), possibilitando a sincronização das mesmas, sem exigir conhecimento de alguma linguagem computacional por parte dos professores.

Sua concepção foi de que o professor pudesse executá-lo em seu próprio computador, não tendo a necessidade de uma conexão com a Internet, o que não ocorre em projetos apresentados no item 2.4 deste trabalho. Essa é uma característica importante, visto que estudos (Magalhães e Schiel, 2000; Schiel, et al., 2000; Souza, 2000; Schiel, et al., 2002a; Guerrini e Castro, 2003) mostraram que muitas escolas públicas brasileiras ainda têm problemas de conexões e de quantidade de computadores conectados à Internet, o que, segundo Kenski (2003), é um motivo de preocupação.

O InMid foi desenvolvido em linguagem $\mathrm{C}++$ Builder 5, é executado em ambiente Windows e foi planejado de forma que todos os arquivos gerados fossem padronizados. Um estudo de layout foi realizado para que o visual do software (figura 7) fosse claro e de fácil manipulação por parte do professor. Sua instalação é fácil e simples, conforme constatado em Magalhães e Schiel (2004), sendo necessária, também, a instalação do RealOne Player ${ }^{24}$, para visualizar o material multimídia produzido.

As características do InMid versão 1.0 são (Magalhães e Schiel, 2003):

- oferece 4 tipos de layout para a apresentação multimídia;

\footnotetext{
${ }^{24}$ http://www.real.com
} 
- $\quad$ possui interface em português;

- permite criar arquivos texto (do tipo RealText) (Anexo A) estáticos ou dinâmicos e no formato de menu com links para a Internet;

- $\quad$ permite criar arquivo RealPicture (Anexo A) sincronizado;

- possibilita alterar cores de fundo e de textos;

- permite inserir título e dados do autor;

- permite a integração com as informações capturadas da lousa pelo Mimio;

- possibilita a inserção de áudio, individualmente;

- gera um documento HTML;

- integra as mídias de forma dinâmica e prática, sem exigir conhecimentos de linguagem computacional.

O InMid possui 5 módulos ${ }^{25}$, a saber: Módulo de Seleção de Mídias, de Edição de Texto, de Inserção de Figuras, de Edição de Itens de Menu (Links para a Internet) e de Edição de Texto de Menu. A figura 7 mostra a tela do Módulo de Seleção de Mídias, que é o módulo principal, do software InMid versão 1.0.

${ }^{25}$ No Anexo A são apresentados os Módulos do InMid. 


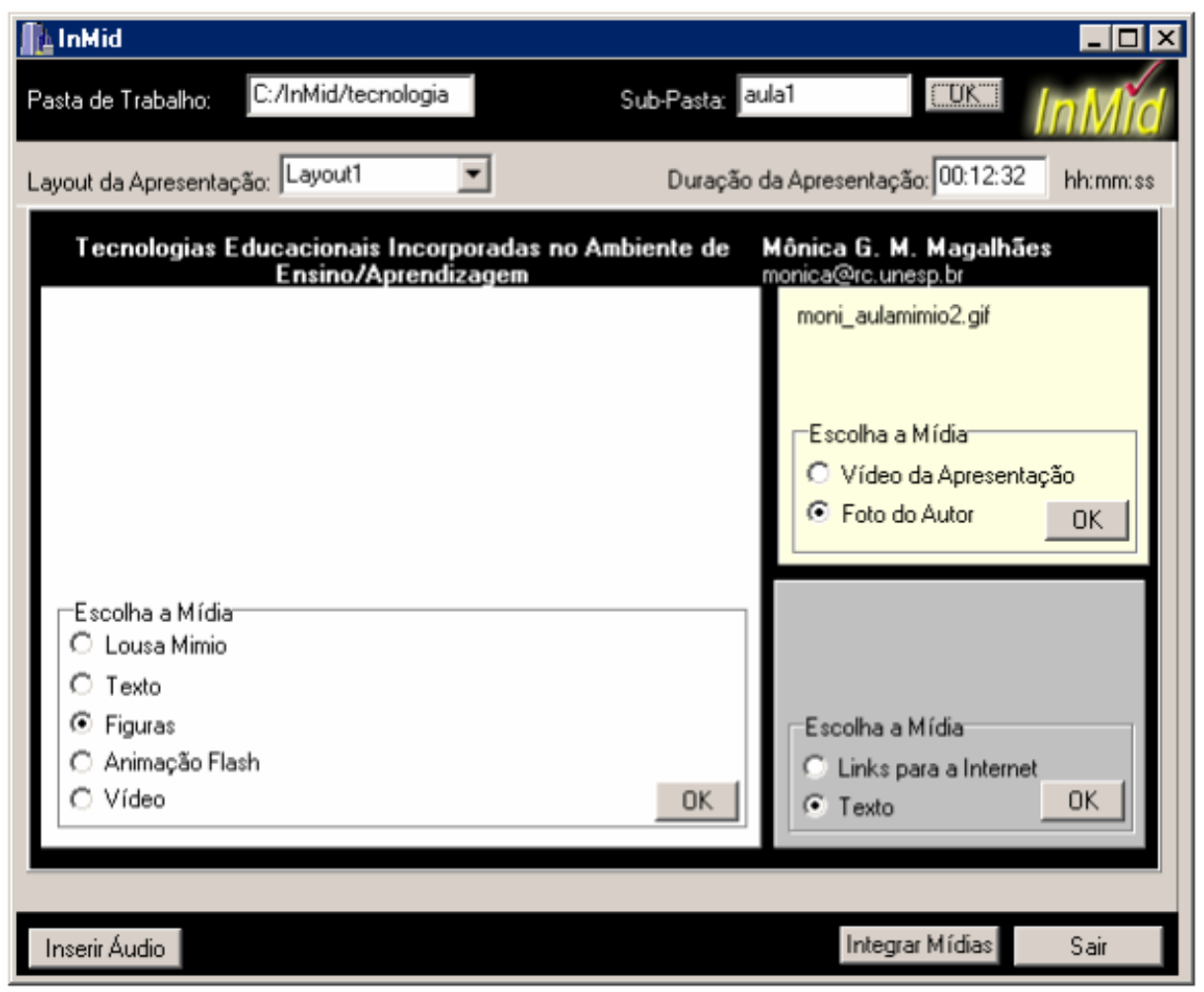

Figura 7 - Módulo de Seleção de Mídias do software InMid 1.0.

Na integração das mídias realizada com o InMid, os seguintes arquivos poderão estar no diretório de trabalho ou de projeto, de acordo com as mídias escolhidas: um documento SMIL com extensão SMI de mesmo nome da pasta de trabalho, um documento HTML, arquivo com extensão RT (RealText), arquivo com extensão RP (RealPicture) ${ }^{26}$, um arquivo CFG (extensão de configuração criada pelo sistema), arquivos de figuras, arquivo de vídeo, arquivo de áudio e arquivo do Mimio com extensão MBC (Mimio BoardCast file). A figura 8 apresenta o fluxo de tarefas do InMid, incluindo a elaboração dos arquivos citados.

\footnotetext{
${ }^{26}$ Ver exemplos dos documentos no Anexo A.
} 


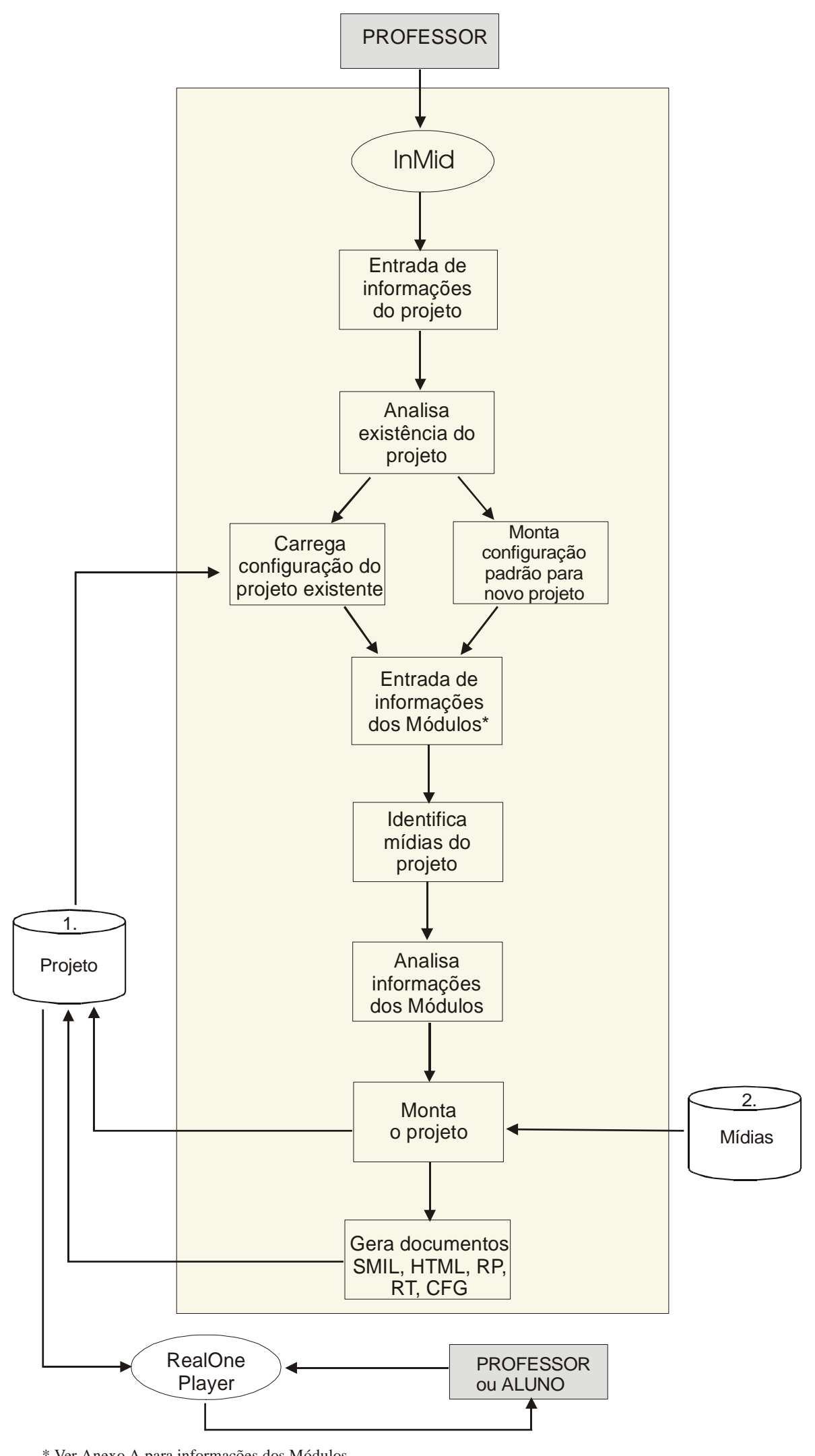

Figura 8 - Fluxo de tarefas do InMid. 
As figuras 9, 10 e 11 são exemplos de material multimídia produzidos na fase de Integração, pelo Software InMid 1.0, onde foram capturadas mídias durante aulas ministradas em 2002.

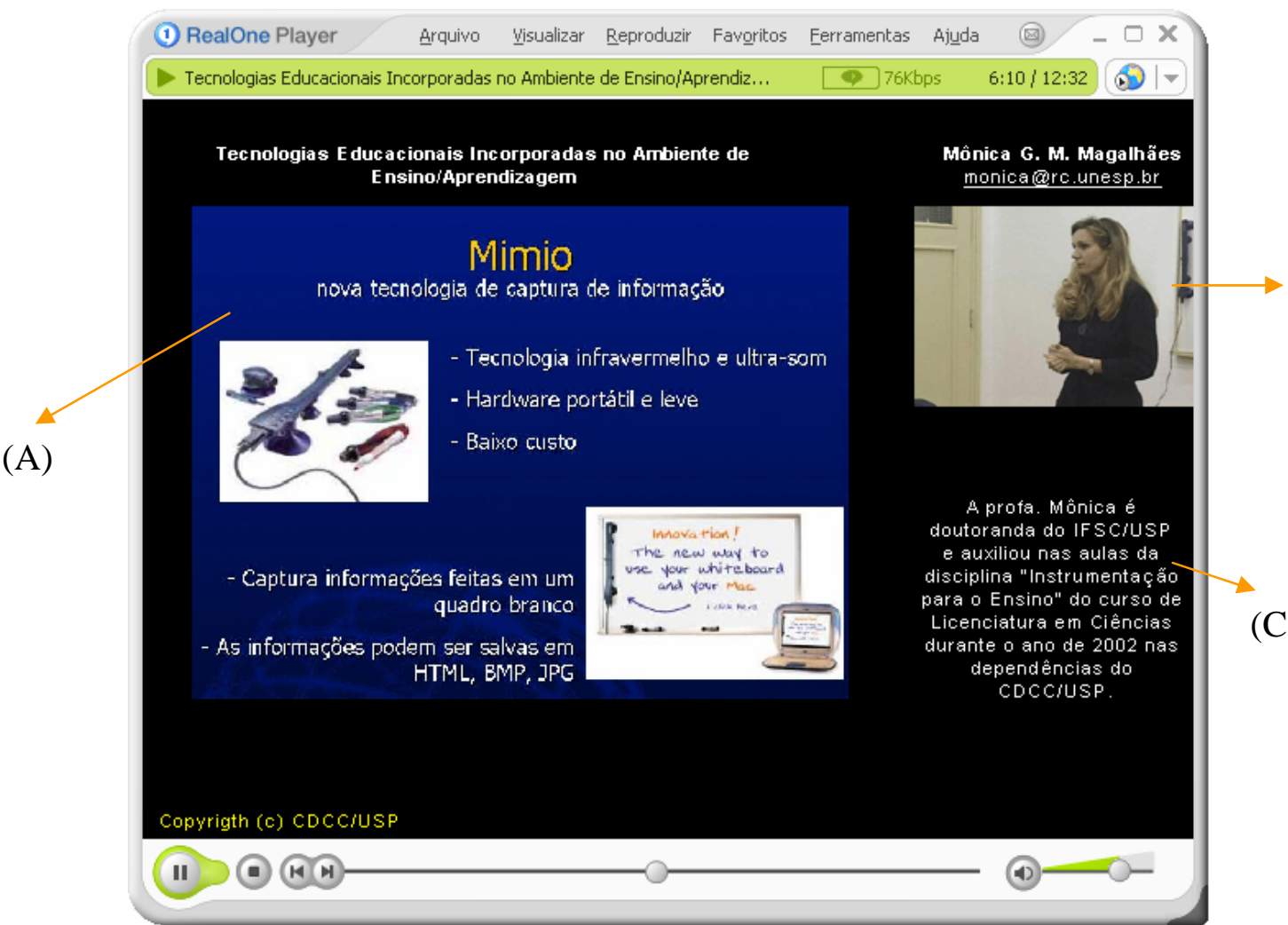

Figura 9 - Exemplo de um material multimídia produzido pelo professor com o InMid. Opção Layout1, com (A) slides, áudio, (B) foto e (C) informações sobre o professor. 


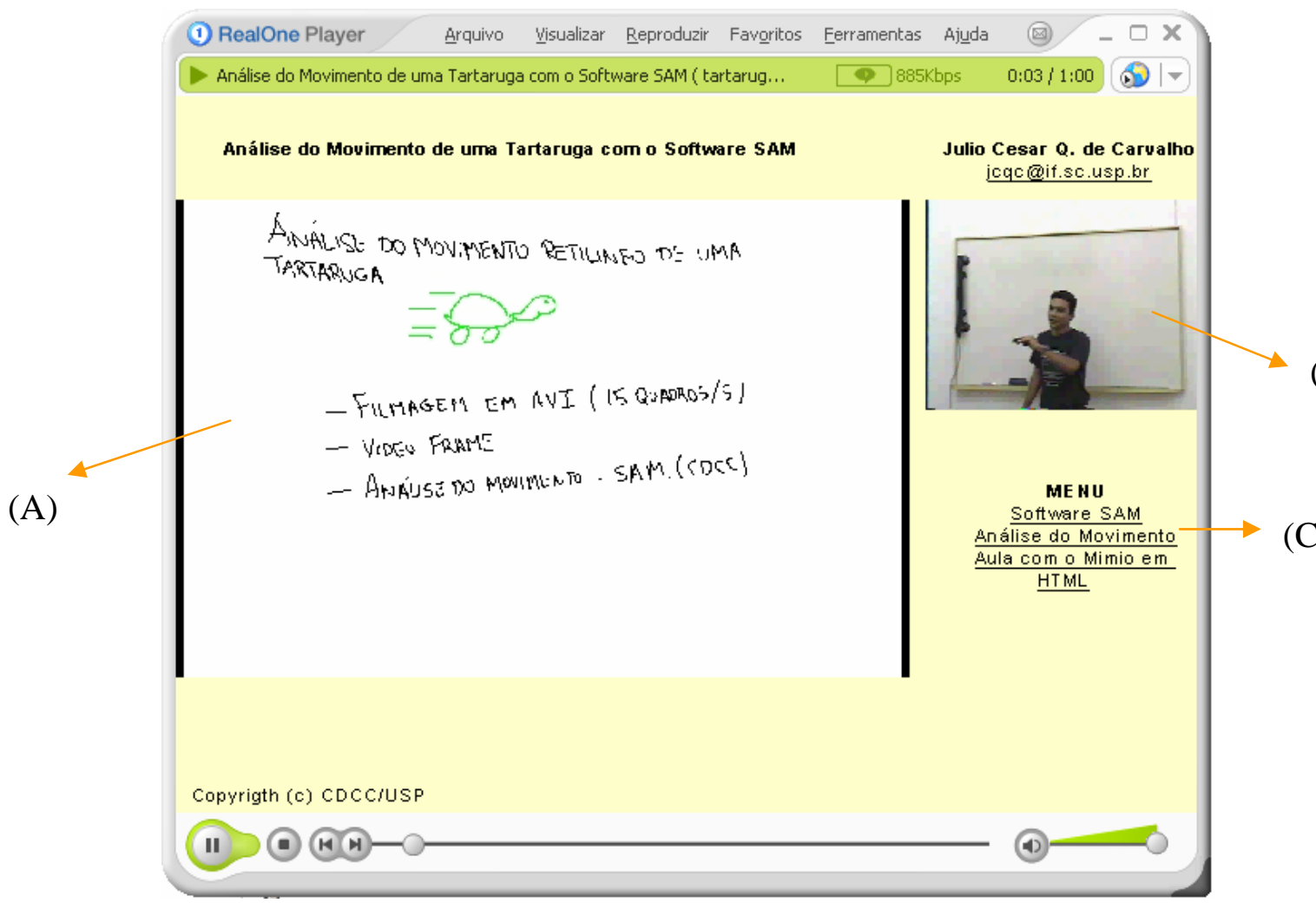

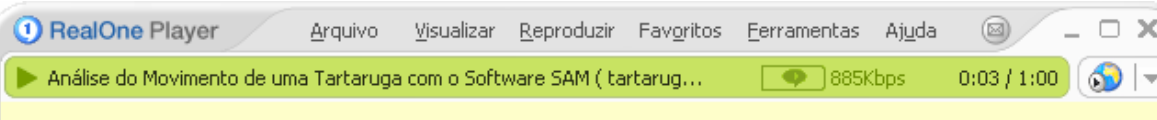

Análise do Movimento de uma Tartaruga com o Software SAM

Figura 10 - Exemplo de um material multimídia produzido pelo professor com o InMid. Opção Layout1, com (A) informações capturas pelo software do Mimio, (B) vídeo da aula e (C) Menu de links para a Internet.

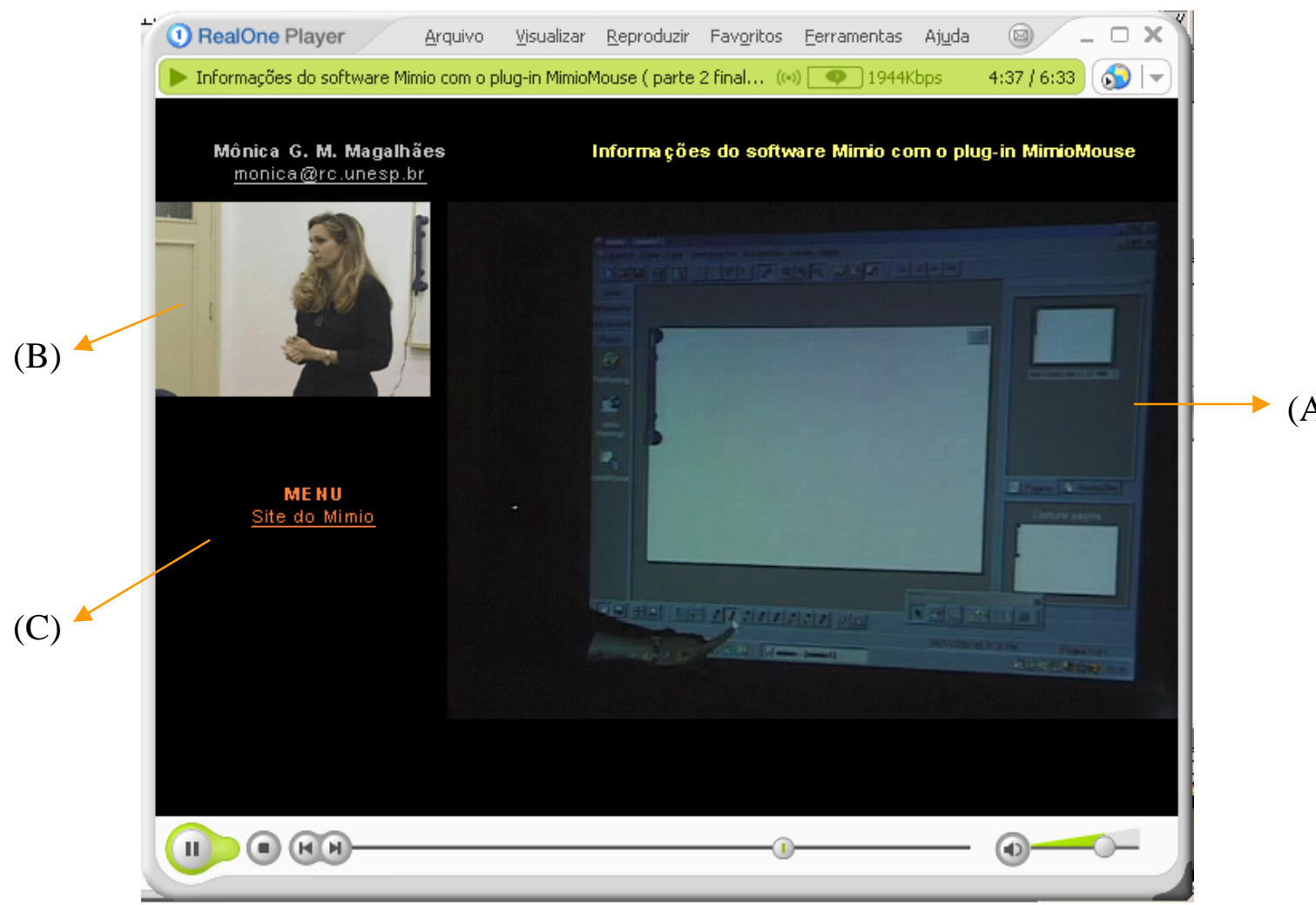

Figura 11 - Exemplo de um material multimídia produzido pelo professor com o InMid. Opção Layout3, com (A) vídeo da aula, (B) foto do professor e (C) Menu de links para a Internet. 


\subsubsection{Fase de Visualização/Distribuição}

Na fase de Visualização/Distribuição estão incluídos o processo de visualização por meio do RealOne Player e o processo de distribuição do material. O InMid gera, além do documento SMIL, um documento HTML para ser visto no Browser Microsoft Internet Explorer (figura 12). Nas duas situações, para visualizar o conteúdo multimídia produzido, é necessária a instalação do RealOne Player, o qual pode ser obtido gratuitamente no site da RealNetworks, ou então, poderá ser instalado a partir do CD-ROM de instalação do software InMid, para os usuários que não possuírem conexão com a Internet.

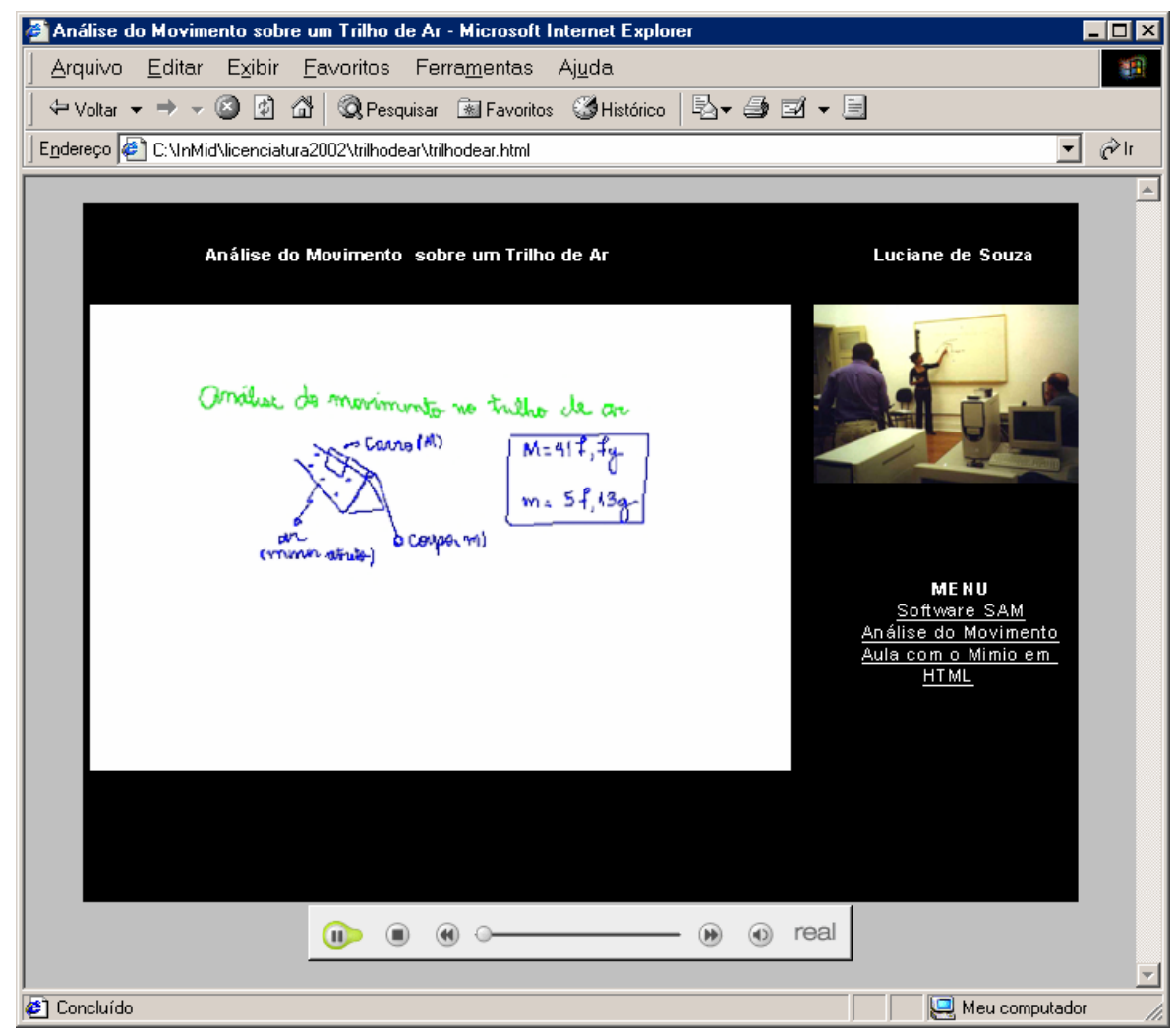

Figura 12 - Visualização do material multimídia no Browser Microsoft Internet Explorer.

Após a integração das mídias e a visualização do material multimídia, o professor terá em seu computador um diretório contendo vários arquivos de mídias e o documento SMIL gerado pelo software InMid. A partir daí, o professor poderá gravar em CD-ROM para distribuição aos seus alunos e também poderá armazenar essas informações em um servidor Real para distribuição no formato streaming. 
Sendo assim, o aluno poderá visualizar o material multimídia em um CDROM ou acessá-lo via Internet, respectivamente.

\subsection{Considerações Finais}

Neste capítulo foram descritos os detalhamentos das fases da metodologia proposta, pois o material pode ser utilizado por formadores de professores ${ }^{27}$, não sendo necessariamente da área tecnológica, que podem usufruir desse material para, inclusive, obter soluções.

A metodologia fornece conhecimentos para o professor na incorporação de tecnologias em suas aulas, explorando os seus recursos e orientando-o na produção do próprio material educacional digital. Serve como um suporte inicial para o professor utilizar tecnologias integradas e foi desenvolvida em fases para distribuir as tarefas a serem realizadas pelo professor.

A primeira fase, definida como de Preparação, é de grande importância pois o professor deve considerar o conhecimento do aluno e o seu conhecimento sobre o conteúdo específico, bem como o conhecimento pedagógico do conteúdo, o qual deve transformar o conhecimento em um formato que possa ser compreensível ao aluno. É nessa fase que a metodologia dá destaque ao conteúdo e não apenas ao uso de tecnologias, sendo um diferencial se comparada com a teoria de Rieber e Welliver (1989).

De acordo com as tecnologias que o professor irá utilizar, os processos de Captura da informação durante a aula e de Edição das mídias após a aula, da fase de Produção, poderão ou não ser executados.

A fase de Integração é o ponto central da metodologia e é onde ocorre a integração das mídias, tendo como proposta a utilização do software InMid. O software InMid foi desenvolvido, especialmente, para que o professor tenha facilidade na integração sincronizada das mídias obtidas, antes, durante e/ou após a aula, gerando um documento SMIL, dentre outros. Assim, o professor não perderá

\footnotetext{
${ }^{27}$ Entende-se aqui por formadores de professores todos os profissionais que estão trabalhando nos cursos de licenciatura, formando os futuros professores a partir de suas especialidades e independente da disciplina que ministram.
} 
tempo na aprendizagem da linguagem SMIL e também não precisará de um especialista em informática para a realização dessa tarefa, após ter tido uma instrução básica sobre esses recursos. Com a utilização do material multimídia produzido nessa fase, ganha-se em possibilidade de aprendizagem, pela utilização simultânea de diversas mídias, pela possibilidade de revisão da aula pelo aluno, pela possibilidade de reflexão do professor sobre sua prática docente e pela possibilidade de interação com o aluno que estiver utilizando o material. Alunos com necessidades especiais, como com deficiência auditiva, podem usufruir desse material multimídia por meio dos recursos de transcrição do áudio. Para os alunos com capacidades normais, usando várias mídias, sua atenção pode ser despertada por um aspecto que na outra mídia não teria o mesmo destaque e isto dá abertura para a rememorização e para uma nova compreensão do mesmo conteúdo.

Na última fase, definida como de Visualização/Distribuição, é realizada a visualização do material pelo professor e a distribuição do material em CD-ROM ou via Internet. As fases anteriores podem ser retomadas antes do material ser distribuído para alterar mídias, fazer correções além de atualizá-lo.

O material multimídia produzido, também pode ser aplicado na EAD, fazendo parte de um ambiente virtual já existente ou como complemento ao conteúdo de um curso à distância. 


\section{Aplicação e Avaliação de Novas Tecnologias e da Metodologia Proposta na Formação Inicial de Professores}

\subsection{Considerações Iniciais: $O$ Objeto da Pesquisa}

Simião e Reali (2002) concluem em seu trabalho que seria desejável a inclusão, na proposta curricular dos cursos de formação de professores, o uso e a análise das potencialidades pedagógicas dos novos recursos da tecnologia.

Nessa perspectiva, após o levantamento e análise das tecnologias de aplicação no ambiente educacional, iniciaram-se estudos para utilização dos recursos tecnológicos em sala de aula. Analisou-se onde aplicar e decidiu-se pelo curso de Licenciatura em Ciências Exatas $^{28}$ da USP/São Carlos, pois, de acordo com a sua definição, são programadas atividades “cuja finalidade é dar ao futuro professor habilidades para construir seu próprio material didático”. E também serão formados

${ }^{28}$ http://www.if.sc.usp.br/grad/cursos_lic.php 
futuros professores, os quais terão oportunidades, durante o processo de formação, de vivenciar papéis distintos, como o de aluno, utilizando as tecnologias para a aprendizagem, e como o de professor, utilizando as tecnologias para o ensino, podendo, dessa forma, serem analisados os dois lados do processo.

A disciplina escolhida foi "Instrumentação para o Ensino", que visa apresentar, ao futuro professor, tecnologias para que ele possa utilizá-las no processo de ensino/aprendizagem. No período em que foi realizado este trabalho, essa disciplina foi oferecida no final do curso. Embora fosse aconselhável superar a seqüência lógica da racionalidade técnica da maioria dos cursos de Licenciatura, onde as práticas situam-se no final do currículo de formação, acredita-se que a proposta de apresentação do desenvolvimento dessas atividades vá contribuir para a ampliação da base de conhecimentos do professor, proposta por Shulman (1987).

A partir da definição do curso e da disciplina, o trabalho iniciou-se com a implantação de diversas tecnologias no decorrer do ano de 2002. Os resultados obtidos desta aplicação ajudaram na finalização da metodologia proposta neste trabalho de pesquisa, a qual foi aplicada e avaliada em 2003 (item 5.3) do ponto de vista de como essa metodologia ajudou o professor a aprender sobre tecnologias e a usá-las pedagogicamente.

\subsubsection{O Curso de Licenciatura em Ciências Exatas da USP/São Carlos}

O curso noturno de Licenciatura em Ciências Exatas da USP de São Carlos foi criado para oferecer uma oportunidade àqueles que se interessam pelo Ensino, de fazer um curso, exclusivamente voltado para a formação de docentes habilitados a ensinar Matemática, Física e Química para o Ensino Médio, e Matemática e Ciências Físicas e Biológicas para o Ensino Fundamental (Licenciatura, 2002). Este curso de graduação é interunidades e, no momento, está sob a responsabilidade do Instituto de Ciências Matemáticas e de Computação (ICMC), Instituto de Física de São Carlos (IFSC) e Instituto de Química de São Carlos (IQSC). Os alunos deste curso são treinados nos vários aspectos da redação de textos didáticos, na apresentação de seminários, na preparação e confecção de 
material audiovisual, etc. A Licenciatura em Ciências Exatas é uma proposta para a formação de recursos humanos necessários ao aprimoramento da educação brasileira. Pretende-se formar um docente com visão das ciências, consciente dos problemas ecológicos do mundo atual e dotado de prática no uso de avançadas tecnologias educacionais. Além de disciplinas específicas de uma licenciatura, são também programadas atividades de caráter prático, em que uma das finalidades é fornecer oportunidades para adquirir habilidades para construir seu próprio material didático (Licenciatura, 2002). A disciplina “Instrumentação para o Ensino" tem como objetivo habilitar o professor a utilizar todo o instrumental à disposição do educador, considerando-se, inclusive, as alternativas de baixo custo e de fácil aquisição (Instrumentação, 2002).

\subsection{Aplicação de Tecnologias: Usando as Ferramentas Separadamente}

Durante esta pesquisa foram realizadas duas experiências na formação inicial de professores: uma, com a utilização de tecnologias separadamente em sala de aula como recurso pedagógico - fase inicial de desenvolvimento da metodologia e a segunda, com a metodologia proposta para auxiliar o professor a utilizar estas tecnologias e a integrá-las produzindo material educacional digital - fase pósdesenvolvimento.

O objetivo da primeira pesquisa foi fazer um levantamento da opinião dos futuros professores sobre o uso de tecnologias em suas aulas, pois, principalmente o Mimio, era uma tecnologia nova "nunca vista por eles", como afirmaram os licenciandos. Por meio de questionário (Anexo E), os futuros professores expressaram sua opinião. Também foram realizadas observações em sala de aula por esta pesquisadora.

Desde 1996, a Internet, mais especificamente a Web, vem sendo aplicada na disciplina de "Instrumentação para o Ensino", quando os futuros professores foram orientados na elaboração de páginas $\mathrm{HTML}^{29}$ como material educacional para

\footnotetext{
${ }^{29}$ Os trabalhos desenvolvidos encontram-se no site http://educar.sc.usp.br/licenciatura/licenc.htm
} 
a Web.

Abdal-Haqq (1995) argumenta que cursos de formação inicial de professores tendem a enfocar aplicações de tecnologias mais simples e comuns, como por exemplo processadores de texto, e dar menos enfoque na exploração de tecnologias mais sofisticadas, como a utilização de mídias integradas. Para o autor, isso é um dos obstáculos no uso de tecnologias mais avançadas pelos professores em suas aulas.

Nesta perspectiva, em 2002 foram programadas atividades, como: a utilização do Software SAM para análise quantitativa de movimentos, atividades de filmagens, dentre outras, com o objetivo de que os futuros professores conhecessem tecnologias disponíveis para aplicação em sala de aula, bem como elaborassem seu próprio material didático. Neste ano, participaram da disciplina nove futuros professores.

Os recursos tecnológicos incorporados em sala de aula para a obtenção de informações em diversos formatos de mídias, foram o Mimio, a câmera de vídeo e o microfone. A integração dessas mídias foi feita por meio de links para as mesmas, a partir de páginas HTML. As etapas realizadas pelos futuros professores foram:

- conhecimento das tecnologias disponíveis;

- planejamento e transformação do conteúdo;

- captura das informações;

- edição das mídias;

- elaboração de páginas HTML;

- distribuição pela Internet.

No final do curso foi aplicado questionário (AnexoE) para obter informação sobre o uso de cada tecnologia, como o Mimio, vídeo, áudio e Internet.

\subsubsection{Utilização do Software SAM na Sala de Aula}

Durante o primeiro semestre de 2002, os futuros professores do Curso de Licenciatura em Ciências Exatas, inscritos na disciplina "Instrumentação para o Ensino", participaram de aulas sobre o software SAM e sobre como fazer filmagens com uma câmera de vídeo tradicional. Após essas aulas, foram definidos os tipos de 
trajetórias de movimento que cada futuro professor analisaria, ficando por conta de cada um as filmagens dos respectivos movimentos.

Os licenciandos filmaram movimentos reais do cotidiano, como: movimento de uma tartaruga, de uma caixa de leite sobre uma esteira de supermercado, de uma bola em um jogo de ping-pong; ou movimentos simulados no laboratório, como: movimento de um corpo oscilando na direção vertical (massamola), de uma colisão entre duas esferas de massas iguais (conservação do movimento linear), de um bloco descendo em uma rampa, de um carrinho se movimentando em um trilho de ar, de uma roda de bicicleta e de uma esfera que rola ao longo de um plano inclinado. As figuras 13 e 14 apresentam algumas imagens obtidas de movimentos reais do cotidiano.

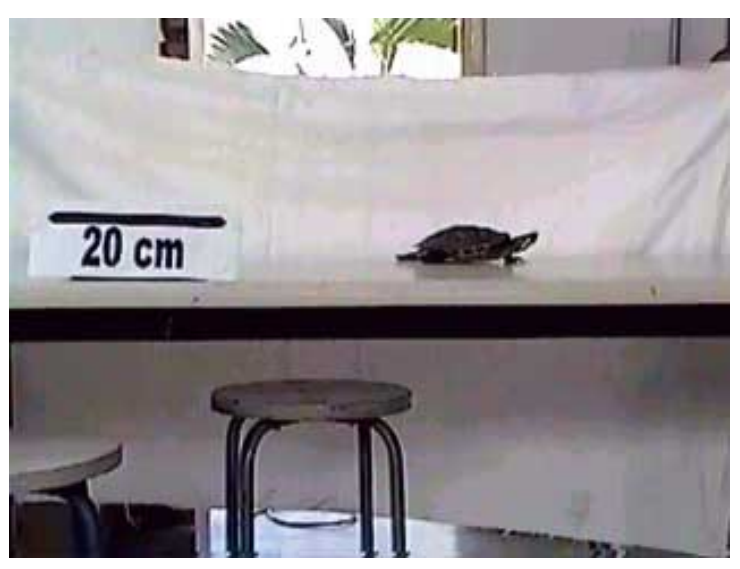

Figura 13 - Movimento de uma tartaruga.

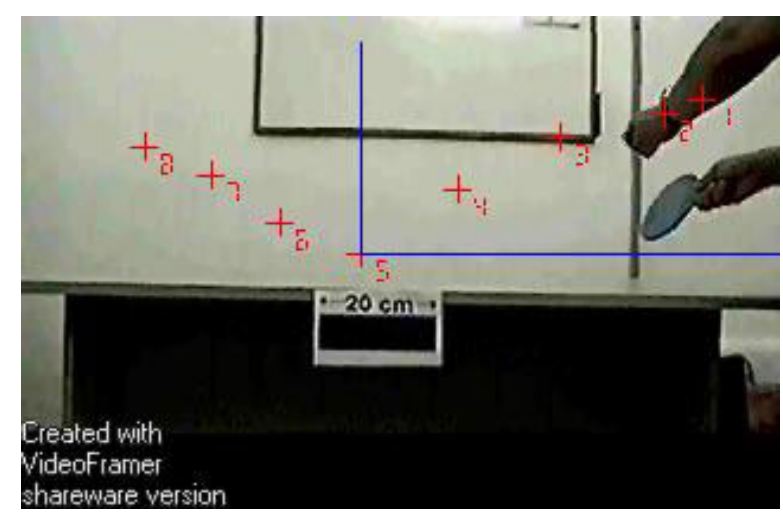

Figura 14 - Movimento de uma bola de pingpong.

Após a filmagem dos movimentos, os futuros professores utilizaram o software VideoFramer versão Shareware para a captura de imagens para o computador que foram salvas com extensão AVI (Audio Video Interleave). Posteriormente, utilizaram o software SAM para a análise quantitativa de cada movimento filmado. O arquivo do filme de extensão AVI foi aberto no software e mostrado quadro a quadro. Os futuros professores obtiveram os dados referentes à posição do objeto, assinalaram as posições com o "marcador" (como mostra acima a figura 14) e mediram a distância com a "régua virtual” do software. Observaram o intervalo de tempo entre um quadro e outro, mostrado no próprio software, e analisaram as medidas quantitativas dos movimentos.

Com os valores dos parâmetros calculados (espaço, tempo, velocidade, 
aceleração e outros), os futuros professores preencheram uma tabela e discutiram os valores físicos encontrados. A figura 15 apresenta exemplo de uma tabela, onde o futuro professor, além de preenchê-la com os valores obtidos e discuti-la, elaborou gráficos a partir dos parâmetros calculados. Viu-se a diversidade de pontos que podem ser abordados por professores e alunos, dependendo da criatividade de cada professor, tanto na elaboração das filmagens quanto na análise dos dados obtidos.

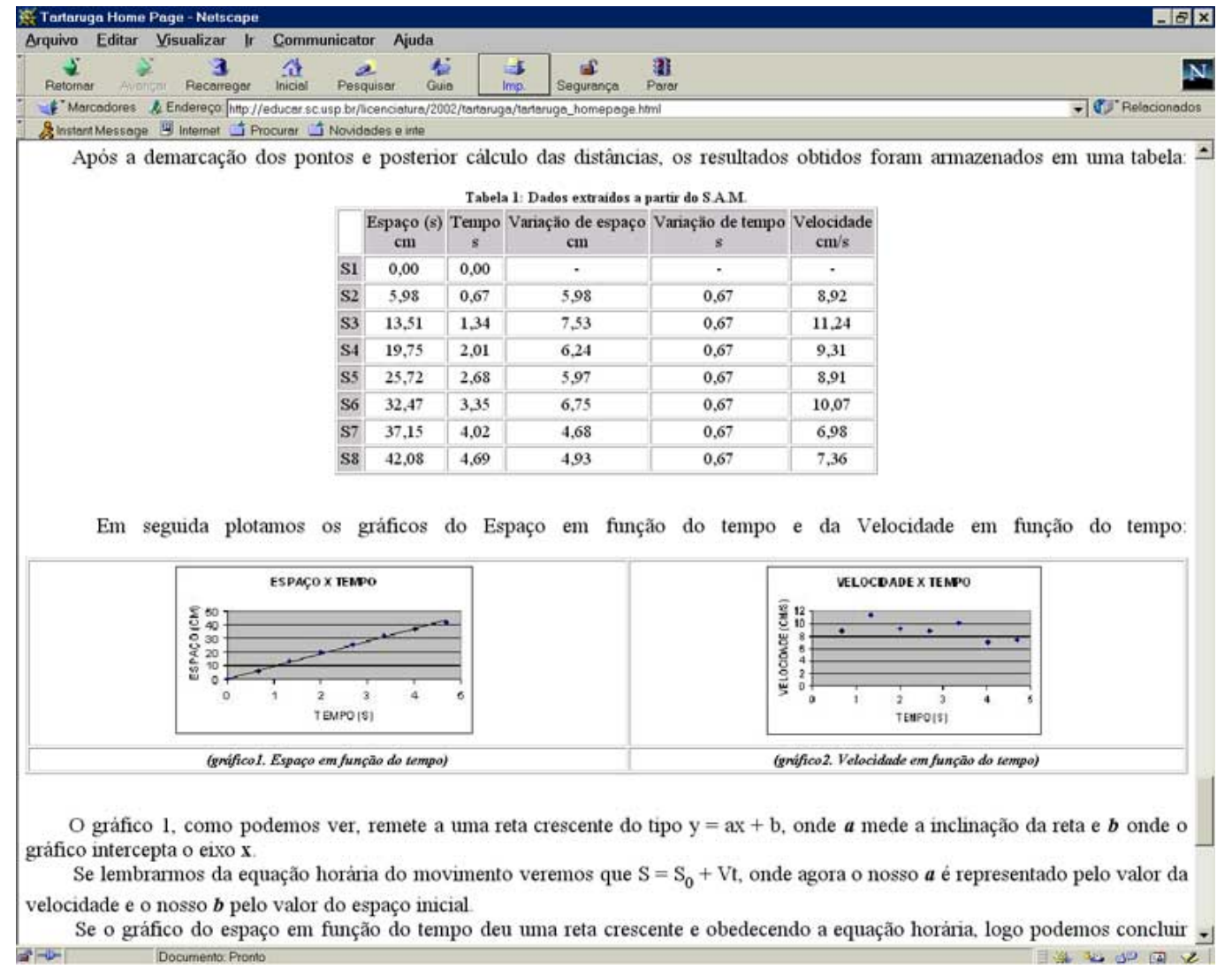

Figura 15 - Exemplo de tabela e gráficos sobre o movimento de uma tartaruga.

\subsubsection{Utilização das Tecnologias Mimio, Foto, Vídeo e Áudio na Sala de Aula}

No decorrer do segundo semestre de 2002, os futuros professores participaram de aulas sobre tecnologias na educação, trabalharam com elas e prepararam suas páginas para a Internet, incluindo links para os recursos tecnológicos utilizados. Foi ministrada uma aula utilizando os recursos do software Microsoft PowerPoint para a elaboração de slides, um computador, o Mimio e um 
projetor multimídia, tendo como assunto a tecnologia na educação. Usou-se a lousa branca com o Mimio instalado, tendo como assunto os recursos da tecnologia Mimio para a captura de informações. Alguns licenciandos testaram a caneta do Mimio e o apagador. Cada um ficou encarregado de preparar uma aula-exemplo de, aproximadamente, 15 minutos sobre o trabalho que haviam feito no software SAM durante o primeiro semestre. Nesta aula-exemplo os licenciandos usariam recursos de tecnologias, como o Mimio, para exposição, captura e armazenamento das informações.

Devido ao interesse de alguns futuros professores pela tecnologia Mimio, não foi necessária muita explicação para utilizá-la. Um licenciando ajudou a instalar o equipamento no computador. Cada um ministrou a sua aula-exemplo com o Mimio e, em seguida, as informações capturadas da lousa branca (figura 16) foram exportadas em HTML. Além da utilização do Mimio, as aulas-exemplos também estavam sendo filmadas para posteriormente serem utilizados o áudio e o vídeo, e também estavam sendo fotografadas (figura 17).

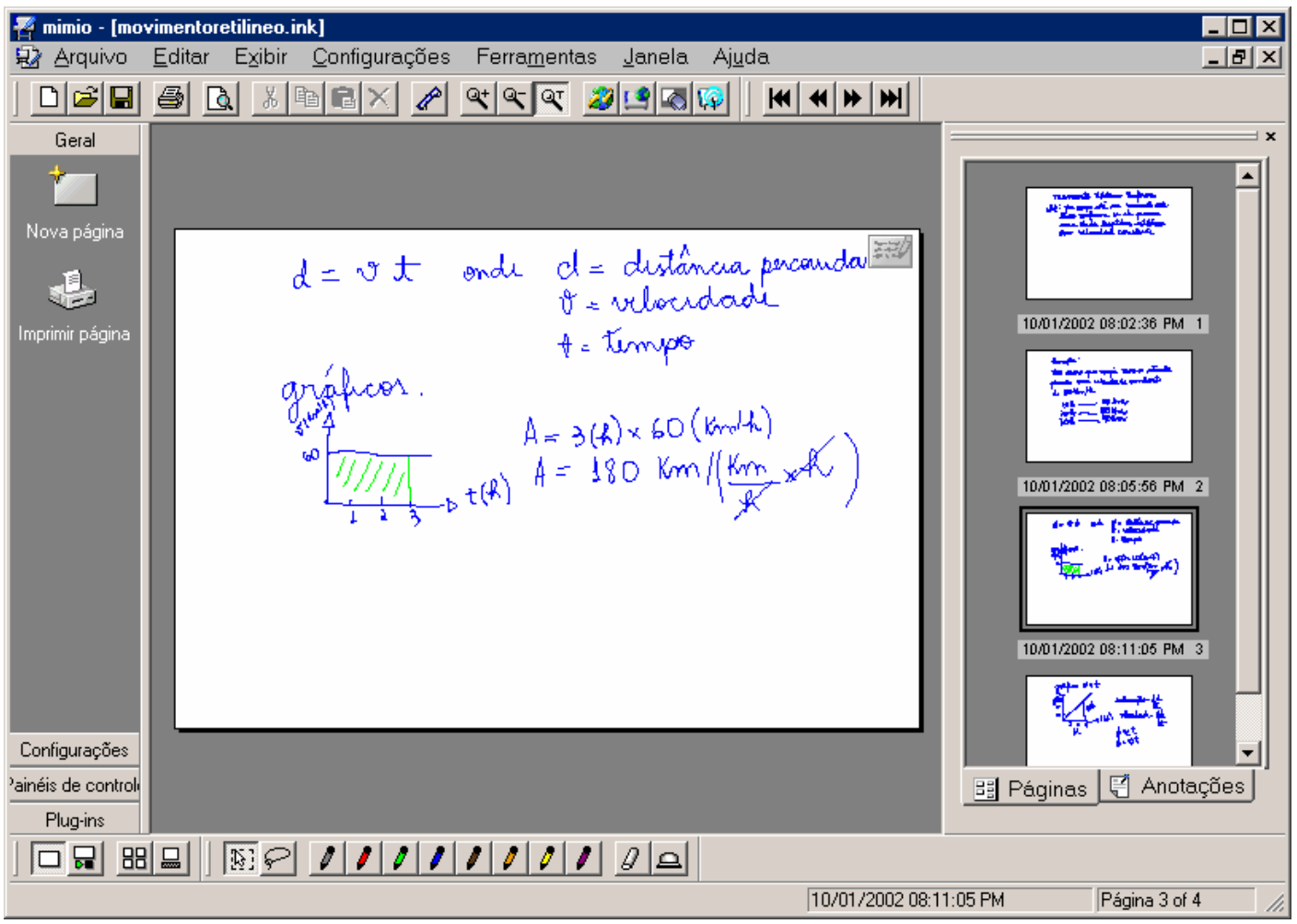

Figura 16 - Informações da aula-exemplo de um futuro professor capturadas e exibidas no software do Mimio. 


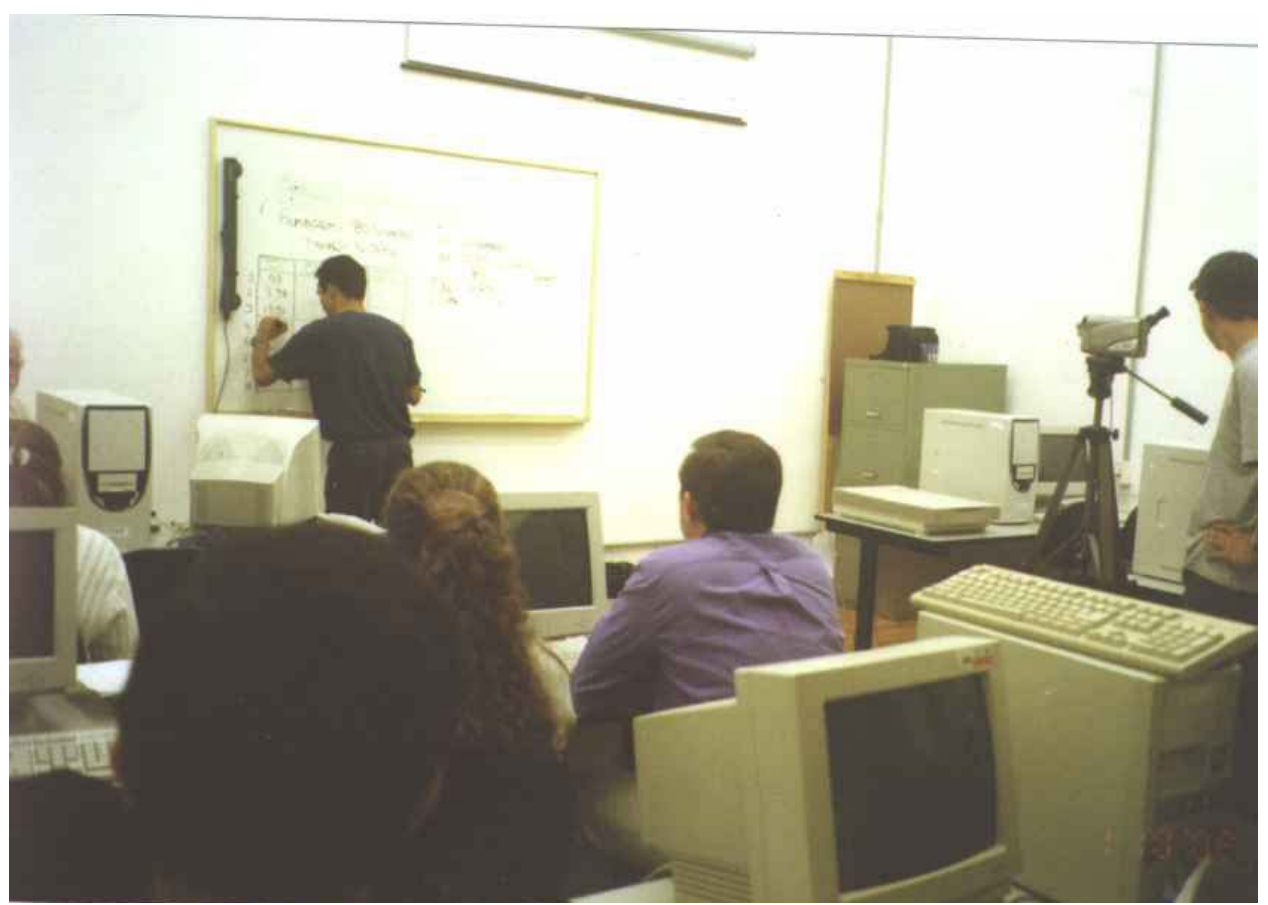

Figura 17 - Aula-exemplo utilizando o Mimio e sendo filmada por outro futuro professor.

Após o término da apresentação das aulas-exemplos, alguns futuros professores verificaram como era a edição de vídeo e a separação do áudio das aulasexemplos filmadas. Foi explicado um editor de HTML para desenvolvimento de páginas para a Internet, enfocando a inserção de links para as mídias capturadas durante as aulas-exemplos ministradas pelos futuros professores. As últimas aulas deste semestre foram de laboratório, para os futuros professores desenvolverem e acrescentarem links nas páginas HTML para as mídias capturadas e armazenadas.

O trabalho final com os nove licenciandos consistiu na publicação de nove páginas HTML ligadas ao site da disciplina ${ }^{30}$, referentes à suas aulas-exemplos, utilizando o software SAM e as tecnologias educacionais. Em todos os trabalhos há textos referentes ao tipo de trajetória do movimento escolhido por cada um dos futuros professores, links para as mídias produzidas durante a aula, bem como explicações de como foi utilizado o SAM. A figura 18 mostra um exemplo de um material educacional desenvolvido em HTML, contendo links para as seguintes informações: texto sobre a fundamentação teórica; texto sobre a parte prática realizada com o SAM, incluindo imagem do movimento filmado (figura 19); páginas HTML contendo informações escritas na lousa obtidas com o Mimio; trecho do vídeo da aula e foto da aula.

\footnotetext{
${ }^{30}$ http://educar.sc.usp.br/licenciatura
} 
(A)

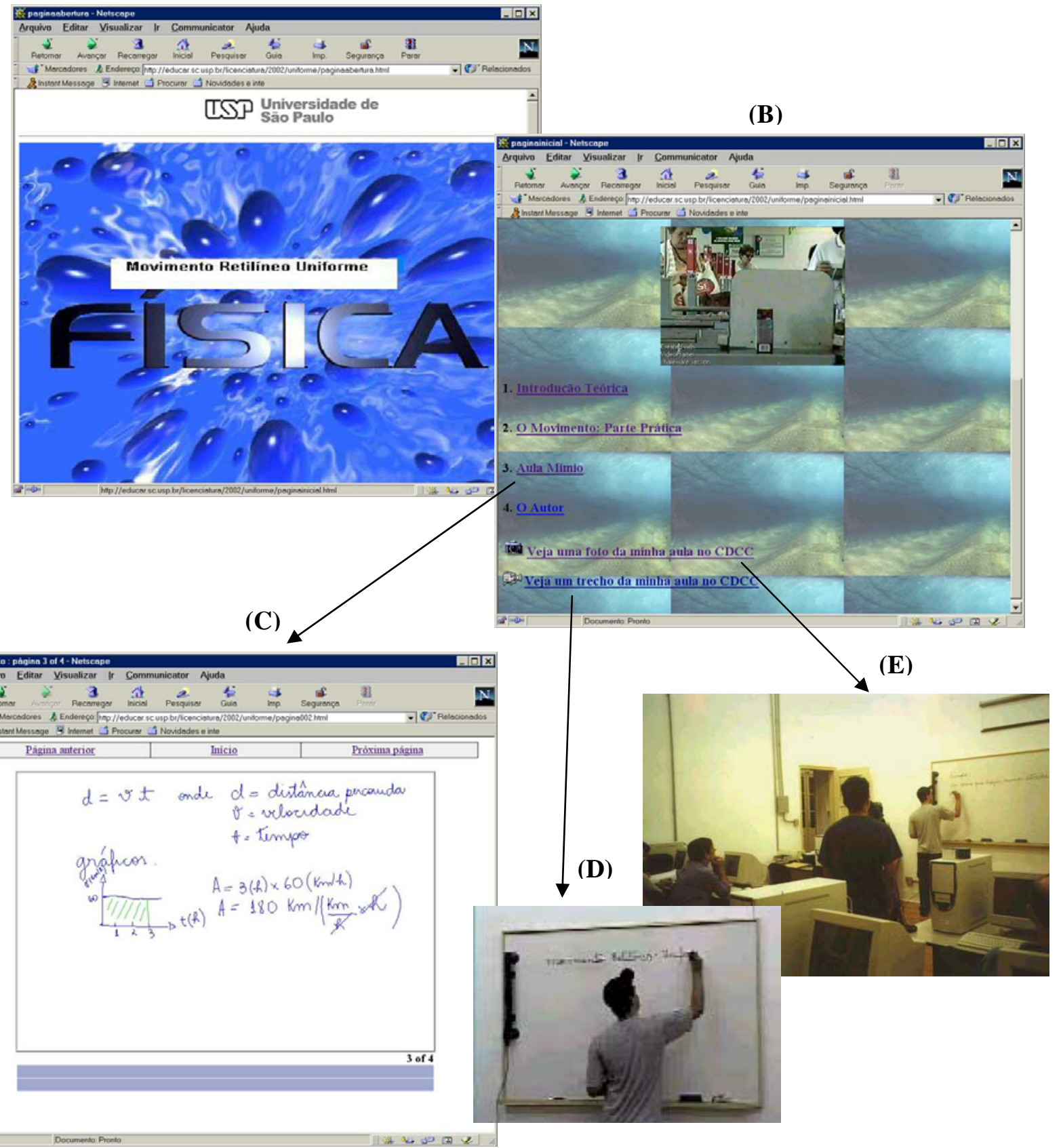

Figura 18 - Exemplo de um trabalho final com links para várias mídias obtidas durante a aula. (A) e (B) - Páginas HTML desenvolvidas pelo futuro professor, (C) - Informações estáticas capturadas da lousa com o Mimio, (D) - Vídeo da aula e (E) - Foto da aula. 


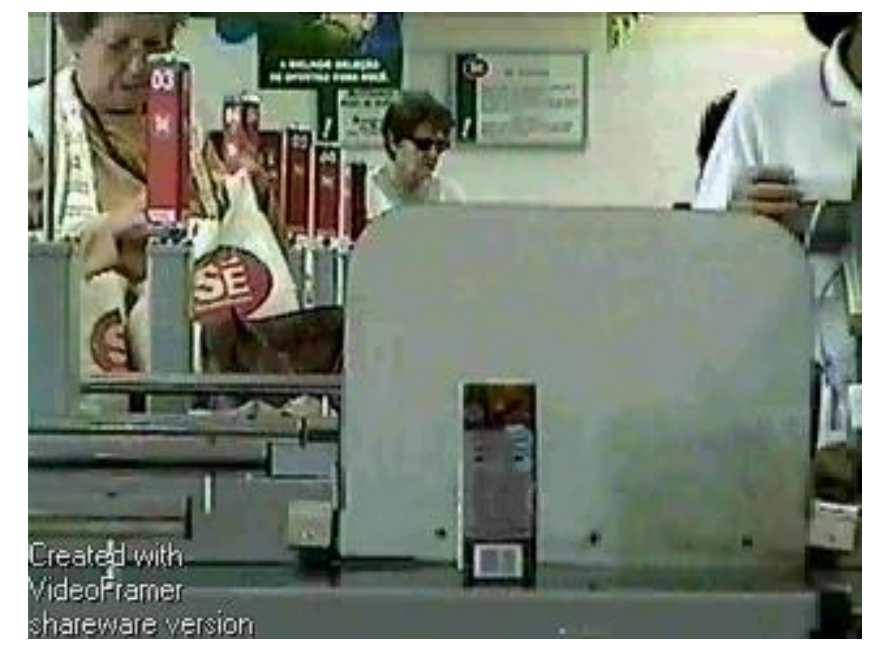

Figura 19 - Vídeo do movimento de uma caixa de leite na esteira do caixa de um supermercado.

A figura 19 mostra a imagem de um movimento real de uma caixa de leite na esteira do caixa de um supermercado. O futuro professor obteve uma filmagem do cotidiano para analisar o Movimento Retilíneo Uniforme no software SAM, disponibilizando um link para esta filmagem em sua página HTML.

\subsection{Aplicação da Metodologia: Integrando as Mídias}

Em 2003, a metodologia proposta neste trabalho foi utilizada por vinte e seis futuros professores na disciplina "Instrumentação para o Ensino" do curso de Licenciatura em Ciências Exatas da USP/São Carlos. A faixa etária dos licenciandos era entre 20 e 32 anos e havia um com 48 anos. Portanto, a idade média da classe era de 26 anos. Todos tinham conhecimentos básicos dos aplicativos do Microsoft Office, como Word, Excel e PowerPoint; 30\% dos futuros professores já trabalhavam com a Internet e 30\% possuíam outros conhecimentos, como Corel Draw, AutoCad, Flash e linguagem de programação.

No primeiro semestre de 2003, também foram desenvolvidas atividades com o software SAM, conforme item 5.2.1. No decorrer do segundo semestre, os futuros professores foram orientados na aplicação da metodologia proposta para auxiliar na incorporação de tecnologias em suas aulas-exemplos e também foram 
treinados na utilização do software InMid para a integração das mídias obtidas antes, durante e/ou após a aula-exemplo.

Os futuros professores tiveram aulas sobre tecnologias e, para orientá-los sobre qual tecnologia utilizar em suas aulas e como utilizá-las, foram aplicados exercícios $^{31}$ onde eles analisavam materiais educacionais multimídia integrados com o InMid pelo professor da disciplina. Os licenciandos foram divididos em dois grupos, onde os que já haviam apresentado suas aulas-exemplos faziam esse exercício em um laboratório multimídia, com fones de ouvido instalados nos computadores, nas dependências do CDCC. Os que ainda não haviam apresentado suas aulas, ficaram em outro grupo, em uma sala de aula equipada com o Mimio onde também estavam disponibilizados filmadora e microfone. Posteriormente, os participantes do segundo grupo também fizeram o exercício.

Essa atividade pode ser chamada de atividade-reflexão, como já abordada no item 4.2.1, pois objetivou a sensibilização dos futuros professores, na visão de alunos, para refletir sobre as tecnologias utilizadas em cada material multimídia, verificando qual a importância e a finalidade de uso de cada mídia em específico. Com esse conhecimento, os licenciandos puderam escolher qual mídia poderia ser melhor aproveitada na fase de Integração, gerando seu próprio material educacional multimídia. Esse processo procurou reafirmar a opinião de Kenski (2003) sobre a formação de qualidade do professor, onde deve ser incluído o conhecimento sobre o uso crítico das novas tecnologias, sendo preciso que o professor saiba usá-las adequadamente no ensino para poder explorar suas especialidades e garantir o alcance dos objetivos do ensino oferecido.

Após esta atividade, cada licenciando ministrou sua aula-exemplo, executando as etapas necessárias da metodologia proposta e obtendo informações em vários formatos de mídias. Com estas informações, foi produzido material educacional multimídia (Anexo B) para ser disponibilizado via Internet ou distribuído em CD-ROM, aos usuários que não possuem acesso à rede ou têm problemas com conexão.

As etapas realizadas pelos licenciandos, durante o segundo semestre de 2003, foram:

\footnotetext{
${ }^{31}$ Ver exercícios no Anexo D.
} 
- conhecimento das tecnologias disponíveis;

- realização da atividade-reflexão;

- planejamento do conteúdo;

- transformação do conteúdo em formas compreensíveis aos alunos;

- captura das informações;

- edição das mídias;

- integração das mídias com o InMid;

- distribuição pela Internet ou em CD-ROM.

Nesse trabalho, os futuros professores que optaram pelo uso do Mimio em suas aulas-exemplos, obtiveram informações dinâmicas (item 4.2.2) por meio do boardCast, formato este diferente das informações estáticas (item 4.2.2) obtidas pelos licenciandos em 2002.

No final da disciplina, foi aplicada uma avaliação (Anexo E) para que os futuros professores pudessem fornecer informações sobre o uso de tecnologias e sobre o uso da metodologia proposta, bem como expressar suas dificuldades e as facilidades encontradas quando da utilização da mesma.

\subsection{Avaliação pelos Futuros Professores}

Foram aplicados métodos de avaliação qualitativos, através de questões dissertativas e da observação dos participantes, e métodos quantitativos, através de questões fechadas. A escala utilizada nas questões fechadas, foi a escala Likert (Preece, 1994; Magalhães, 1997; Magalhães e Schiel, 2000) com níveis de 1 a 5, respectivamente - “Muito Fraco”, “Fraco”, “Médio”, “Bom” e “Muito Bom”.

Em 2002, o questionário (Anexo E) foi elaborado para obter informações sobre o uso de cada tecnologia pelo futuro professor, como Mimio, vídeo, áudio e Internet, com o objetivo de entender o processo que os licenciandos vivenciaram. Pesquisas posteriores poderão utilizar estas informações para futuras análises e comparações. As questões fechadas versaram sobre a classificação da tecnologia Mimio em sala de aula quanto à sua facilidade de uso. As questões dissertativas abordaram as dificuldades encontradas no uso da tecnologia Mimio, a opinião dos 
futuros professores com relação às tecnologias de vídeo, fotos, Mimio e páginas Internet, se estas tecnologias em conjunto poderão facilitar o processo de ensino/aprendizagem, se apenas a tecnologia Mimio contribuiu para o ensino/aprendizagem, o que o futuro professor mais gostou na utilização desta tecnologia e o que poderia ser melhorado. Observações também foram realizadas no decorrer do curso a fim de conhecer como os licenciandos utilizaram cada tecnologia e quais suas dificuldades no momento da aplicação em sala de aula. No término do ano letivo de 2002 foi aplicada a avaliação, sendo que 5 licenciandos entregaram o formulário respondido.

Em 2003, procurou-se elaborar questões (Anexo E) para também obter informações com o objetivo de entender o processo que os futuros professores vivenciaram durante a disciplina do curso de Licenciatura. As questões dissertativas procuraram investigar se a definição das fases da metodologia proposta auxiliou os futuros professores na incorporação de tecnologias em suas aulas, em qual fase encontraram dificuldades, quais tecnologias foram utilizadas em suas aulasexemplos, o que mais gostaram na utilização das tecnologias, a opinião dos futuros professores com relação ao software InMid para a integração das tecnologias, se o material multimídia produzido pode contribuir para o processo de ensino/aprendizagem. As questões fechadas versaram sobre o Layout e a facilidade de uso do software inMid. No término do ano letivo de 2003 foi aplicada a avaliação e responderam ao questionário, vinte e um licenciandos.

\subsubsection{Resultados da Avaliação}

\section{a) Uso de tecnologias}

Nas respostas obtidas em 2002, sobre o Mimio, verificou-se que o futuro professor considerou a sua importância para o processo de ensino/aprendizagem na visão de aluno e de professor. Os futuros professores, enquanto alunos, acharam que o Mimio é uma tecnologia muito interessante. Durante as aulas, os licenciandos verificaram que tiveram oportunidade de estar sempre atualizados com o conteúdo 
ministrado pelo professor da disciplina e que puderam prestar mais atenção na aula, pois não precisaram anotar o que o professor escrevia. Acharam que o Mimio é um facilitador, tanto para o professor, quanto para o aluno, podendo ser melhor aproveitado o tempo de aula.

Como professores, os licenciandos acharam que o Mimio contribuiu para melhorar as apresentações da sua aula e que tanto o hardware quanto o software do Mimio são fáceis de serem utilizados. Entretanto, verificaram que, para usufruir as vantagens dessa tecnologia, o professor precisa estar muito bem familiarizado e acostumado a dar aulas com o equipamento, pois, em suas aulas, tiveram problemas de falhas de escrita nas informações capturadas da lousa pelo Mimio (conforme figura 20).

Os futuros professores consideraram muito relevante o trabalho com novas tecnologias na disciplina, pois os manteve atualizados. Porém, houve comentários, em especial sobre a tecnologia Mimio, como:

“Não vou dar aula numa escola que tenha este equipamento”.

“Muito bom, mas é uma coisa que não se encontra nas escolas por aí”.

“Acredito que não serão usadas com freqüência, na prática, pela falta de equipamento”.

Todos os licenciandos, com relação à questão sobre as dificuldades encontradas na utilização do Mimio, foram unânimes em responder que o ponto a ser melhorado seria no reconhecimento da escrita, pois exige que o professor tenha um certo treino nessa tecnologia. As figuras 20 e 21 mostram a comparação de uma lousa, da mesma pessoa, durante a mesma aula-exemplo; apesar de haver alteração no texto escrito na lousa, pode-se notar nitidamente a diferença da obtenção dos dados pelo software do Mimio. Seria necessário, portanto, um tempo de adaptação do futuro professor ao uso da caneta e do apagador, antes do mesmo utilizá-lo em sua aula. 


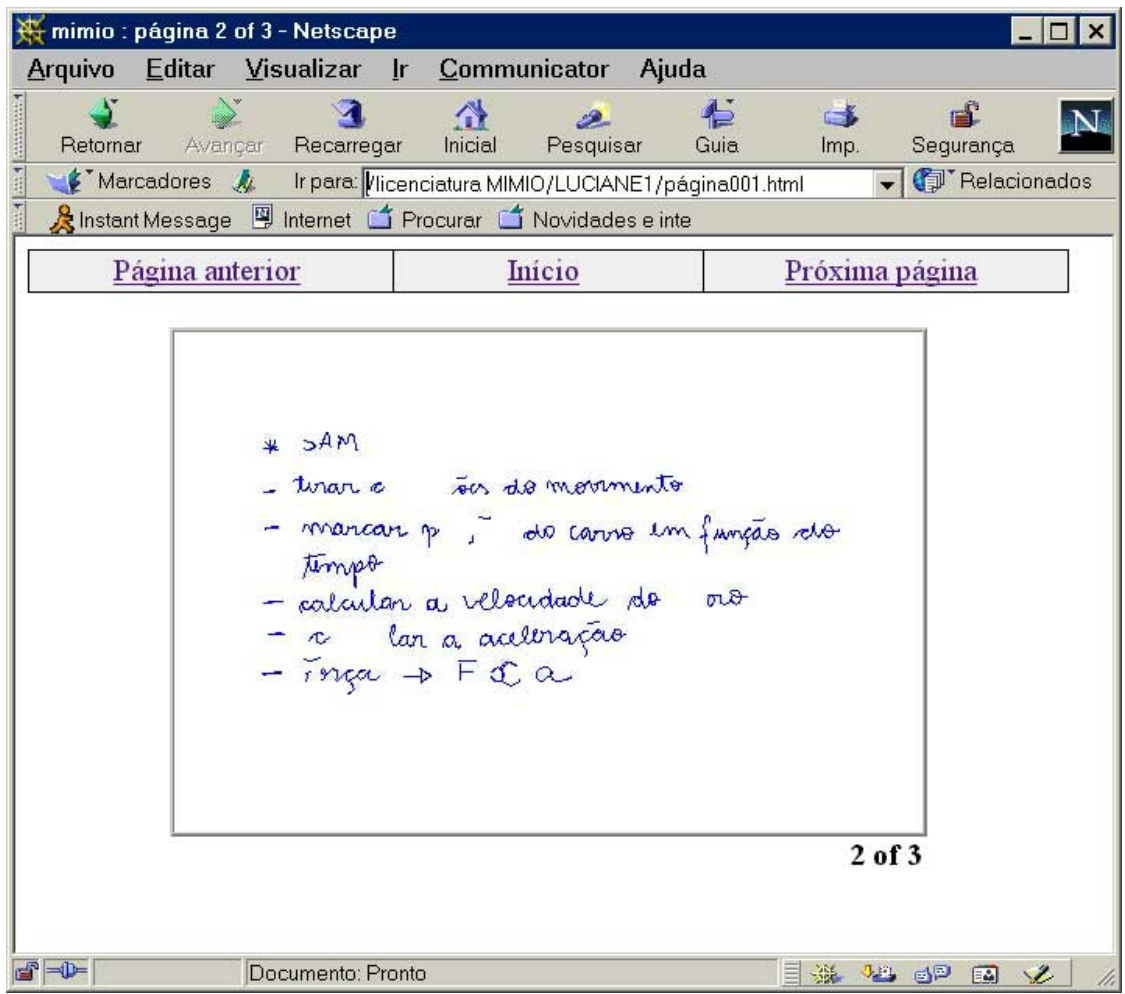

Figura 20 - Informações capturadas da lousa com falhas de escrita.

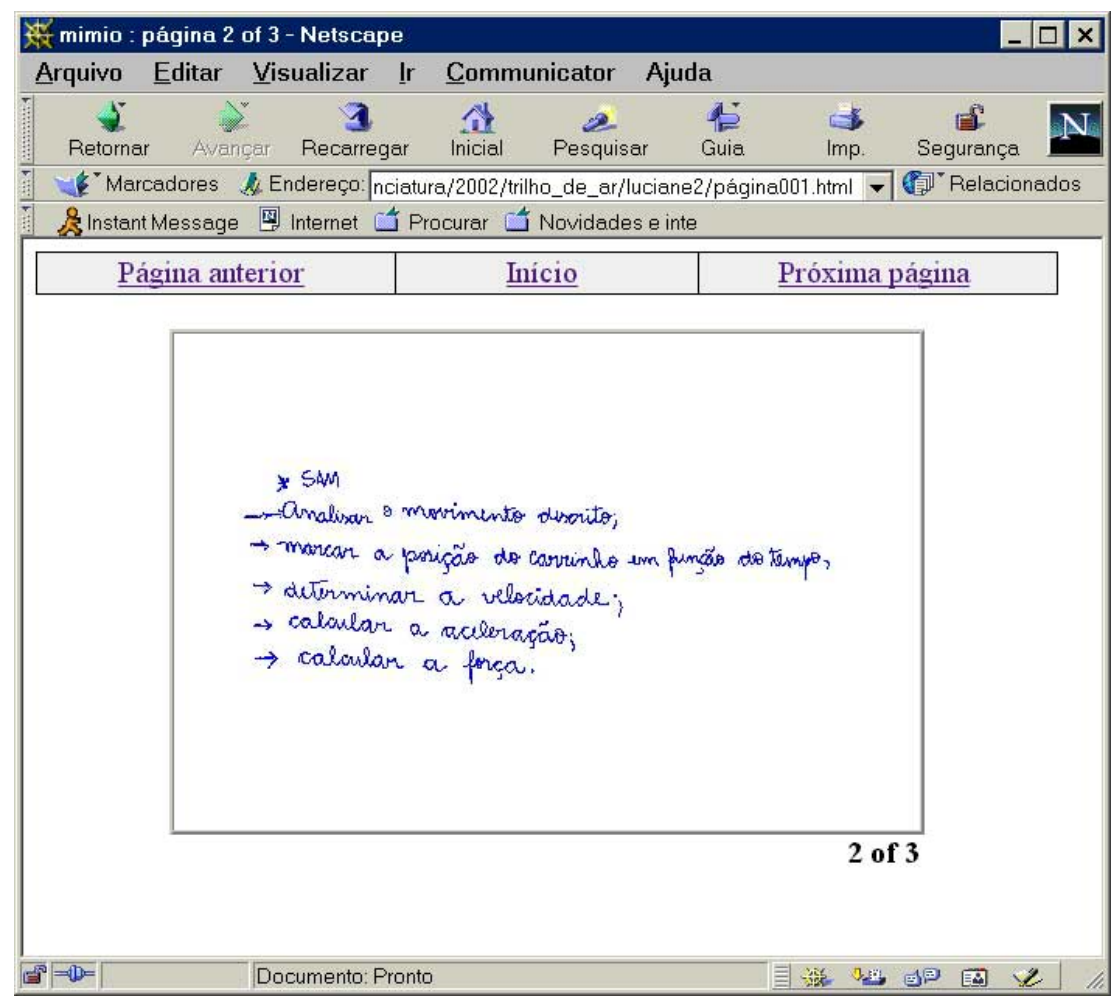

Figura 21 - Informações capturadas da lousa sem falhas de escrita.

Sobre o que mais gostaram, os futuros professores responderam que foi o fato das aulas serem armazenadas e vistas posteriormente, conforme resposta em 
destaque:

"Poder "armazenar" as lousas e assim "ver" o que os alunos viram e ainda poder reproduzir e melhorar a cada aula, podendo analisar cada aula com cautela posteriormente".

Se as tecnologias Mimio, vídeo, áudio, fotos e páginas Internet, em conjunto, poderão facilitar o processo de ensino/aprendizagem, os licenciandos acharam que essas tecnologias oferecem todo o recurso para facilitar a elaboração de cursos à distância ou como complemento à aula convencional, possibilitando um melhor entendimento do conteúdo. Acharam que é um ótimo auxíliar para o professor e que sua aula pode ser eficiente, desde que saiba utilizar tais recursos. Levantaram o problema do professor ter muitas turmas para preparar aula e pouco tempo para utilizar todas as ferramentas que estão à sua disposição. Este pode ser um problema inicial, porém, pode ser minimizado com a reutilização em outras aulas de algum material digital já elaborado pelo professor.

Os resultados dos dados quantitativos da avaliação, referentes ao software e hardware do Mimio, utilizando a mencionada escala Likert, ficaram entre Médio e Bom.

\section{b) Integração de mídias}

Em 2003, os resultados da avaliação mostraram que a metodologia proposta foi aprovada por todos os futuros professores e foi de grande auxílio para incorporar tecnologias em suas aulas, pois proporcionou facilidades e transparência na realização das tarefas, facilitou a produção e a integração das mídias, ajudou a melhorar seu desempenho, foi muito importante para haver uma construção do conhecimento. A definição da metodologia, em fases, ajudou os futuros professores a compreendê-la gradualmente e de maneira organizada. Os licenciandos acharam importante que a metodologia deixasse claras as fases, no desenvolvimento pedagógico, usando as várias mídias e integrando-as. O que mostra que a metodologia tem um valor interessante como apoio pedagógico ao professor, conforme alguns destaques: 
“A fase de Preparação foi de fundamental importância para conhecermos os recursos tecnológicos disponíveis e, posteriormente, poder optar pelos mais adequados à aula ministrada”.

"A partir do momento em que o trabalho foi esquematizado com a metodologia, a dedicação e a consciência da necessidade de cada etapa ajudaram a melhorar nosso desempenho".

"Foi feito de forma organizada e permitiu que fôssemos pensando uma etapa de cada vez".

"Pudemos acompanhar todo o processo utilizado para a produção de aulas a partir das novas tecnologias”.

"Pude compreender melhor a metodologia de incorporação de tecnologia, gradualmente, e de maneira organizada”.

Sobre as dificuldades encontradas durante a aplicação da metodologia, pode-se destacar que $48 \%$ dos licenciandos não encontraram dificuldades; $14 \%$ encontraram dificuldades na fase 1 de Preparação, por levar um certo tempo para a preparação do conteúdo; 19\% encontraram dificuldades na fase 3 de Integração, metade destes por ser algo novo e a outra metade por utilizar a opção de transcrever o áudio, o que demorou mais tempo para ser feito; 19\% acharam dificuldades na fase 2 de Produção, metade destes por não possuírem experiência prévia com tecnologias e a outra metade por sentir insegurança e nervosismo pelo fato da aula ser filmada, conforme respostas a seguir:

“Na gravação da aula, pois quem não está acostumado fica nervoso”.

"Na fase 2, sem dúvida, a parte que encontrei maior dificuldade foi a de captura de informação, graças à insegurança frente à câmera de vídeo”.

As tecnologias utilizadas pelos futuros professores em suas aulasexemplos foram vídeo, áudio, slides, fotos, texto descritivo, links para a Internet e o Mimio. Com relação à utilização destas tecnologias em sala de aula, os futuros professores gostaram do vídeo e do áudio, da integração das mídias feita pelo software InMid, de conhecerem novas tecnologias, as quais poderão ser aplicadas com seus alunos. Acharam que as aulas com o Mimio foram muito interessantes e que esta tecnologia deixou a aula mais interativa e dinâmica e que o Mimio, 
associado ao áudio, é uma revolução para a eficácia do ensino à distância. Alguns destaques:

"A utilização das tecnologias em sala de aula, desde que usadas com bom senso, pode tornar uma aula, sobretudo à distância, mais dinâmica”.

"Novos instrumentos que poderei aplicar com meus alunos, quando começar a dar aulas”.

"Gostei de conhecer os recursos disponíveis para se aplicar em uma boa aula, como por exemplo o mimio, do qual eu nunca tinha ouvido falar”.

"É uma proposta muito interessante, visto que o aluno pode aprender utilizando vários recursos audiovisuais”.

"Gostei, pois pude entrar em contato com tecnologias que gradualmente serão incorporadas nos sistemas de ensino”.

Sobre o InMid, todos os futuros professores acharam que é um software simples, fácil de ser utilizado e que possui um bom layout. Na figura 22 são exibidos os resultados dos dados quantitativos da avaliação, quanto à facilidade de uso e ao Layout do software InMid, utilizando a escala Likert de 5 níveis, onde 1 é Muito Fraco, 2 - Fraco, 3 - Médio, 4 - Bom e 5 - Muito Bom.

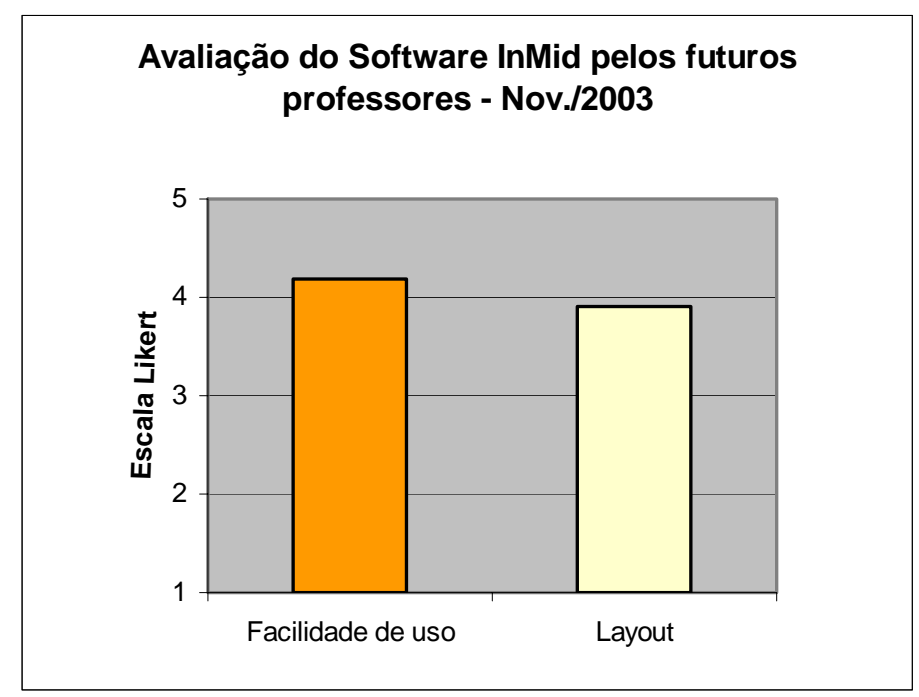

Figura 22 - Avaliação do software InMid pelos futuros professores, utilizando a escala Likert. 
Sobre o que mais gostaram no InMid, os licenciandos responderam que foi o fato de proporcionar uma aula dinâmica, de permitir a inserção de textos, a possibilidade de integrar as mídias, a praticidade de uso, do resultado final quando tudo já estava integrado, da interface do InMid, das opções de escolha do Layout da aula e da possibilidade de escolher as mídias a serem integradas. Poderia ser acrescentado um menu de abertura de arquivos e mais ícones ao invés de textos. Daí o fato da avaliação ser mais baixa para o item Layout apresentado na figura 22. Um futuro professor comentou que a qualidade do vídeo poderia ser melhorada, mas esse não seria um recurso realizado pelo InMid e sim na edição das mídias.

Sobre o material multimídia produzido com o InMid, na fase de Integração, todos os licenciandos acharam que pode contribuir para o processo de ensino/aprendizagem. Eles consideraram que é um material interessante e que pode ser revisto pelo aluno. Os futuros professores citam que o material multimídia produzido por eles durante a disciplina contém informações do cotidiano, com assuntos interessantes e bem relacionados aos problemas e acontecimentos do dia-adia, além de ser uma poderosa ferramenta de apresentar os conteúdos. Nesta questão é destacada a dificuldade de utilização de recursos tecnológicos em escolas públicas, conforme depoimento de um futuro professor: "Sim, se for em escolas particulares, pois em escola estadual fica um pouco difícil”. A seguir são destacadas algumas respostas:

"Acho que o produto gerado na integração das mídias pode contribuir bastante no processo de ensino/aprendizagem porque resulta num trabalho bastante claro, de fácil consulta e de excelente qualidade. Além disso, os assuntos abordados pelos alunos foram em geral, interessantes $e$ bem relacionados aos problemas e acontecimentos do nosso cotidiano".

"Sem dúvida, contribui positivamente para o ensino. Quanto à aprendizagem, cabe ao aluno utilizar adequadamente o recurso para explorar a aula e apreender o conteúdo, pois este não tem a interação direta do professor".

"Pode contribuir, desde que seja bem realizado”.

"Desperta a atenção do aluno" ... “contribui para uma revisão da matéria pelo aluno, além de contribuir para uma aprendizagem mais 
dinâmica”.

"É uma ferramenta a mais auxiliando no processo e pode atingir alunos que tenham maior dificuldade com os meios tradicionais”.

"Trata-se de uma aula (bem sucinta) que foi ministrada utilizando diferentes recursos, que podem contribuir para prender o interesse dos alunos".

"É possível distribuir um conteúdo e chamar a atenção para pontos relevantes".

"Deve ser usado tendo muita experiência com os recursos, pois senão tiver, pode atrapalhar".

Certos itens sobre EAD foram levantados por alguns futuros professores em respostas sobre o material multimídia produzido por eles, conforme destaque a seguir:

“No ensino à distância facilitaria o processo de ensino/aprendizagem”.

\subsubsection{Discussão dos Resultados}

\section{a) Aspectos operacionais}

O software SAM foi utilizado como uma nova tecnologia no auxílio ao ensino de Física. Pôde-se observar que os futuros professores ficaram motivados ao utilizá-lo em sala de aula. Os movimentos analisados com o SAM fazem parte do cotidiano, o que facilita a aprendizagem das concepções científicas.

Nas observações em sala de aula, verificou-se que o Mimio é uma tecnologia de manuseio simples e barata (seu valor é de, aproximadamente, 1/5 do valor de uma lousa eletrônica de tamanho 1,56m x 1,26m.). É de grande valia nas aulas de Física, para o Ensino Médio, onde o professor precisa de uma lousa para demonstração de fórmulas e resultados, ao mesmo tempo em que explica um fenômeno físico. Também pode ser muito útil em aulas de matemática no Ensino Médio, durante as demonstrações de equações e fórmulas. 
As canetas usadas pelo Mimio são do tipo hidrográficas, montadas em cápsulas que possuem emissores infravermelhos e de ultra-som, cujos sinais são monitorados pela barra de captura. Ao pressionar uma dessas canetas sobre a lousa, ouve-se um leve zunido, informando ao sistema o movimento da caneta e qual cor está sendo usada, sendo também reproduzida no computador. As diferentes cores das canetas do Mimio foram reconhecidas pelo software. O apagador eletrônico também possui emissores infravermelhos e de ultra-som e funciona de maneira semelhante.

Durante a aplicação em sala de aula, observou-se que o apagador e a caneta devem ser movimentados sem muita pressa para não perder o contato com a barra de captura. Isto pode ser observado quando não se ouve o zunido. Conclui-se que o professor precisa de um pouco de treino e calma para que o sistema funcione bem, produzindo bons resultados na tela do computador.

Quanto às dimensões estipuladas de utilização da lousa branca com o Mimio (de $0,60 \mathrm{~m}$ x 0,90 $\mathrm{cm}$ a 1,2m x 2,4m), não houve problemas. O software do Mimio usou registro baseado em vetores para criar um filme dos dados capturados no quadro. Para cada uma das telas, poderiam ser acrescentados comentários do tipo texto, por meio de uma seção de notas prevenindo a perda de dados. O problema encontrado nesses comentários é que não se pode acrescentar acentos no texto, mesmo na versão em português do software. Os dados capturados foram salvos pelo software do Mimio no formato original INK e foram exportados como arquivos HTML (quadros estáticos).

Não foi constatada importância relevante dos quadros estáticos capturados pelo Mimio, porém, notou-se a necessidade de algo dinâmico e com algum sincronismo com o áudio que poderia ser capturado durante a aula. Além disso, constatou-se uma despadronização do material educacional produzido, pelo fato de cada futuro professor elaborar a sua própria página HTML com links para as mídias capturadas durante a aula.

Diante de tal análise, vislumbrou-se a necessidade do desenvolvimento de uma metodologia para a integração de tecnologias, incluindo uma fase onde a integração de mídias fosse feita de uma forma simples e direta, para que os professores não necessitassem de conhecimento mais aprofundado de linguagens computacionais para desenvolver páginas HTML e para integrar mídias. Portanto, a pesquisa realizada em 2002, forneceu subsídios para o desenvolvimento da 
metodologia para integrar tecnologias em sala de aula e produzir material educacional multimídia, conforme relatado no Capítulo 4.

Pôde-se perceber, durante as aulas-exemplos, que houve futuros professores que primeiro escreviam todo o conteúdo na lousa e, posteriormente, o explicavam aos alunos. Para estes, utilizar a lousa branca com o Mimio como metodologia de ensino, não seria o mais indicado. Durante as observações em aula, verificou-se que alguns licenciandos estavam apegados a copiar um dado conteúdo de um livro ou de anotações pessoais, o que desmotivava a interação com os alunos. Neste caso, o ideal seria utilizar um software para elaboração de slides, como o PowerPoint, para preparar a aula-exemplo, previamente, e depois explicar os itens, evitando a perda de tempo de escrita na lousa. Para isto, seria necessário utilizar um projetor multimídia ligado a um computador. Se desejassem, também poderiam utilizar o Mimio como um mouse sem fio, usando o plug-in MimioMouse ${ }^{32}$.

Pelo que se pôde observar durante a aplicação desse trabalho, muitos licenciandos tiveram dificuldades com o vídeo, porque falavam muito rápido ou por excesso de ruídos e má iluminação na sala. Desse modo, sugere-se que o professor fale pausadamente, que o local da filmagem tenha o mínimo de interferência externa e seja bem iluminado. Antes da aula, seria interessante o professor fazer uma prévia do que seria dito em sala de aula e do que seria mostrado.

Destacando uma das respostas,

“... a utilização das tecnologias em sala de aula, desde que usadas com bom senso, pode tornar uma aula, sobretudo à distância, mais dinâmica”.

pode-se notar a percepção do licenciando para com cursos à distância utilizando novas tecnologias em sala de aula além de textos, como visto em exemplos de EAD estudados por Mendes (2003) que ainda há muita predominância do texto escrito nesta modalidade de ensino.

Sobre a utilização de novas tecnologias em suas aulas, os futuros professores gostaram de conhecer e utilizar novos recursos e da utilização do InMid na integração de mídias, achando-o um software fácil e simples de usar, atingindo o objetivo do desenvolvimento do mesmo. O material produzido com o InMid, além de ser usado pelos professores para a reflexão da sua prática docente e pelos alunos para 
a sua aprendizagem, também pode ser utilizado em cursos à distância e com alunos com necessidades especiais. Algumas sugestões de melhorias no InMid foram citadas pelos licenciandos:

“... o InMid é ótimo. Só achei que poderiam ter outras opções nas escolhas da mídia, por exemplo, colocar o vídeo e a foto no mesmo layout".

(Esta opção já existia, porém não foi explorada pelos licenciandos durante a aula-exemplo)

“... acho que ao entrar no programa os diretórios deveriam ficar gravados para não precisar digitar toda hora”.

(Já foi providenciada esta alteração)

“... talvez algumas opções de layout mais flexíveis, tais como tamanho da mídia, seria interessante”.

(Esta alteração poderia ficar para uma segunda versão)

“... gostei da interface do programa InMid. Poderia introduzir mais ferramentas de edição, e o programa poderia apresentar mais ícones ao invés de textos".

(Esta alteração poderia ser estudada para uma segunda versão)

\section{b) Aspectos econômicos e de infra-estrutura}

De acordo com os comentários de futuros professores, destacados nas páginas 87 e 92 deste texto, pode-se notar a baixa expectativa dos licenciandos quanto à utilização de novas tecnologias principalmente nas escolas públicas. Os licenciandos têm consciência que, atualmente, estas tecnologias ainda são de difícil acesso na escola comum, mas que, no futuro, podem estar presentes no dia-a-dia da sala de aula, conforme depoimento a seguir:

"Pude entrar em contato com tecnologias que gradualmente serão incorporadas nos sistemas de ensino”.

Os futuros professores encontraram algumas dificuldades na fase de Produção relacionadas a problemas pessoais, como ficar em frente a uma câmera de vídeo, e na fase de Integração, devido à novidade da tecnologia utilizada. De certa forma, a metodologia não satisfaz a proposta de Perrenoud (2000) neste caso, não no

\footnotetext{
${ }^{32}$ Mais informações sobre o MimioMouse ver Apêndice I.
} 
uso da informática, mas no uso da câmera de vídeo. Perrenoud (2000) destaca que não é necessário ser um especialista em informática para utilizar adequadamente esta ferramenta.

Os licenciandos sabem que o mercado de trabalho é seletivo na questão sobre o uso de novas tecnologias e reconheceram a importância do conhecimento adquirido no decorrer do curso sobre as mesmas, conforme declaração a seguir:

“... no mercado de trabalho, atualmente, há cada vez mais a procura por profissionais qualificados. Com o conhecimento tecnológico aqui adquirido, acredito que me enquadro neste perfil”.

\section{c) Aspectos metodológicos e dinâmica em sala de aula}

Respondendo à questão sobre o que mais gostaram, os licenciandos citaram que foi o fato das aulas serem armazenadas e vistas posteriormente, tanto pelo aluno, para uma revisão, como pelo professor, para uma reflexão sobre a prática de ensino. Pode-se notar que os futuros professores reconheceram a importância do armazenamento das informações, não somente para que os alunos pudessem revê-la, mas também, para que o professor pudesse analisar o seu desempenho e refletir sobre o mesmo, retomando o conceito de Shulman, citado no item 3.3, página 40 deste texto, onde a reflexão também é importante para aprender da prática. Evidenciou-se, então, a importância da atuação do professor em relação à utilização e emprego das mídias, subsidiado por teorias educacionais, como a de Shulman, em conjunto com a metodologia proposta, que permitam identificar em quais atividades essas mídias têm maior potencial e são mais adequadas.

Pudemos observar em suas respostas, e constatar com o acompanhamento de suas aulas-exemplos, que os licenciandos buscaram o desenvolvimento de seus conhecimentos científicos e demonstraram interesse na melhoria de suas práticas docentes, por quererem conhecer novas formas de ensinar o conteúdo utilizando novas tecnologias.

O depoimento de um futuro professor, apresentado a seguir, confirma a questão sobre a construção do conhecimento, definida por Shulman, e mostra que a metodologia causou impacto em sua formação, não apenas para uso das tecnologias: 
“... a definição das fases foi muito importante para haver uma construção bem embasada dos conhecimentos”.

Verifica-se a importância da metodologia proposta para a construção do conhecimento relacionado à forma como é ensinada a matéria. Esse fato nos faz retomar a contribuição de Shulman, descrita no item 3.3, páginas 38 e 39 deste texto, sobre o conjunto de conhecimento característico da profissão docente, onde o conhecimento pedagógico do conteúdo, apontado pelo autor como o mais importante dentre os demais que compõem a base do conhecimento do professor, representa a combinação entre o conhecimento da matéria a ser ensinada e o conhecimento pedagógico e didático de como ensiná-la. Nota-se que, com a introdução de novas tecnologias no processo de ensino/aprendizagem, esse tipo de conhecimento, como é visto no depoimento do professor, tem sua importância reforçada. Salienta-se que para a realização da integração do conteúdo da disciplina com a tecnologia é necessária a construção do conhecimento pedagógico do conteúdo.

O próprio licenciando reconheceu, como Shulman propõe, que para o uso das tecnologias com fins pedagógicos o professor precisa ter outros conhecimentos além das técnicas envolvidas no curso, como conhecimentos pedagógicos aprofundados, do conteúdo específico que será ensinado, e o próprio conhecimento pedagógico do conteúdo. Simião (2001), já em seu trabalho, verificou também o aspecto de que o uso das tecnologias (software educacional) não garante, por si só, um ensino adequado. Portanto, reconheceu-se, como Simião e Reali (2002), que a forma como o professor utiliza os seus conhecimentos pedagógicos e de conteúdo específico na elaboração de situações de aprendizagem, é um aspecto relevante no ensino.

Os depoimentos destacados a seguir, demonstram que a maioria dos futuros professores ressaltou o cuidado pedagógico:

“... a utilização das tecnologias em sala de aula, desde que usadas com bom senso, pode tornar uma aula, sobretudo à distância, mais dinâmica”.

“... pode contribuir, desde que seja bem realizado”.

“... deve ser usado tendo muita experiência com os recursos pois senão tiver, pode atrapalhar”. 
Quanto ao material multimídia produzido na integração das mídias, todos os futuros professores acharam que pode contribuir no processo de ensino/aprendizagem. O fato das informações apresentadas na sala de aula serem armazenadas, podendo ser vistas posteriormente, propicia dinamismo, inovação, facilidade de consulta, revisão do conteúdo das aulas pelo aluno e reflexão sobre a prática de ensino pelo professor, reafirmando os três aspectos importantes para o acesso ao saber, salientados por Shulman e citados no item 3.3, páginas 39 e 40 deste texto: necessidade da participação dos pares, de um sistema de anotações registrando as idéias sobre a prática docente e da reflexão por parte do professor.

A atividade-reflexão realizada em sala de aula com material multimídia fez com que os licenciandos refletissem sobre a utilização de cada tecnologia e qual seria de melhor aplicação para a sua aula-exemplo. Nesse contexto, o uso da metodologia desenvolvida proporcionou uma nova visão da aplicação da tecnologia, não somente como auxílio aos alunos em sua aprendizagem, mas também como ferramenta educacional que pode ajudar a melhorar a prática docente.

Pode-se considerar que a utilização de novos recursos tecnológicos em sala de aula deve ser feita com total consciência das suas facilidades e dificuldades. No depoimento, a seguir, o licenciando levantou a hipótese do aluno vir a ter uma atitude passiva diante de um material multimídia:

"Sem dúvida, uma aula produzida com a utilização dos recursos tecnológicos e disponível na Internet pode romper distâncias entre o educador $e$ o educando, contribuindo para o processo de ensino/aprendizagem. Acredito, no entanto, que a utilização de tal recurso numa sala de aula deve ser feito com cautela; se o aluno tiver acesso a uma aula tão completa onde pode ouvir o professor $e$ acompanhar suas explicações, ele pode terminar por menosprezar a necessidade de participar da aula. Sabemos, no entanto, que por mais dinâmica que seja a aula final, produto da integração das mídias, o aluno terá uma atitude passiva, postura não desejada para um processo de ensino/aprendizagem eficaz. Sem dúvida, os recursos tecnológicos podem e devem, na medida do possível, ser incorporados à sala de aula, $e$ as atividades desenvolvidas ao longo do curso foram de grande importância para que tivéssemos acesso aos recursos disponíveis”.

Portanto, deve ser destacado que o material multimídia produzido pelos licenciandos pode ser um complemento à aula, onde o aluno pode revisá-lo para as provas, para uma melhor compreensão do conteúdo ou, até mesmo, em alguma 
ocasião na qual não pôde estar presente na aula. O material também pode servir para o professor refletir sobre a aula ministrada, sobre o conteúdo, armazenando-o para ser apresentado em aulas futuras. Neste ponto, é válido reforçar as palavras de Shulman a respeito do armazenamento da aula: - para o autor, sem um sistema de anotação, a análise, interpretação e codificação dos princípios da prática são dificilmente recuperadas, sendo que a reflexão também é necessária para o professor aprender com a experiência. Destacamos ainda, o alerta contido na opinião do licenciando que mostra que, por mais interessantes que sejam os recursos tecnológicos, de forma alguma eles conseguirão solucionar todos os problemas da educação. 


\section{Conclusão}

Durante uma experiência de aplicação de novas tecnologias com futuros professores, verificou-se a necessidade de uma metodologia que os orientasse no uso dessas tecnologias em suas aulas, integrando as informações obtidas em um material educacional digital. Desse modo, desenvolveu-se a metodologia e um software para a integração sincronizada de mídias, o InMid.

A metodologia proposta inclui fases e processos que orientam o professor a refletir sobre o uso de novas tecnologias e a saber como usá-las, visando a produção de material educacional multimídia, dando um enfoque não somente à tecnologia, mas também, ao conhecimento pedagógico do conteúdo e ao material educacional a ser produzido, o que a difere da teoria de Rieber e Welliver.

Essa metodologia foi aplicada em um curso de licenciatura com a finalidade de incluir no currículo a preparação de futuros professores no uso de novas tecnologias de maneira inovadora, eficaz e apropriada. Na aplicação da primeira fase da metodologia, durante o processo de Conhecimento das tecnologias, foi realizada uma atividade para a reflexão dos licenciandos, como alunos, sobre a finalidade de cada recurso tecnológico utilizado nos materiais multimídia produzidos e apresentados pelo professor da disciplina. Vista a sua importância, decidiu-se por incluí-la como parte integrante da primeira fase da metodologia proposta, intitulando o processo de “Reflexão sobre o uso das tecnologias”.

Várias tecnologias foram utilizadas em sala de aula pelos licenciandos para analisar movimentos e capturar experiências diárias de professores e alunos. As 
informações obtidas foram integradas e transformadas em material educacional multimídia para uso posterior. Os futuros professores produziram este material usando o InMid. O software pode ser melhorado, porém já mostrou sua eficácia, pois o produto final ${ }^{33}$ foi alcançado com as aplicações que foram realizadas neste trabalho. O InMid também mostrou ser simples e de fácil manuseio, além de possuir interface em português e usar informações obtidas de recursos tecnológicos que a maioria das escolas já possuem. Não precisa de grandes investimentos, mesmo que necessite de treinamento inicial dos professores ou de um técnico para executar alguma tarefa, caso o professor não tenha tempo. A metodologia, inclusive o software InMid, foram avaliados para aferir os resultados, propondo melhorias, e para estimular os professores no uso de novas tecnologias em suas aulas e na inclusão destas em seus métodos de ensino.

Os aspectos - investimento na aplicação de tecnologias na formação inicial do professor e sua participação na produção de conteúdos adequados que usem novas tecnologias - foram obtidos com o desenvolvimento da metodologia proposta para fins educacionais e sua aplicação na formação inicial de professores o que, para os licenciandos, teve boa aceitação tanto como professores quanto como alunos.

Verificou-se que o contato com as novas tecnologias mudou a forma dos futuros professores refletirem sobre a prática docente, ou seja, interferiu no conhecimento pedagógico do conteúdo. Nesse contexto, a metodologia proposta pode proporcionar aos futuros professores algum desenvolvimento de seu conhecimento pedagógico do conteúdo, pois oferece diversas hipóteses de utilização do conteúdo com as novas tecnologias.

Neste trabalho havia o interesse maior em analisar como a metodologia proposta para a integração de mídias, contribuiu para que os futuros professores pudessem usar as tecnologias em suas aulas. Para isso, respondemos as seguintes questões levantadas: 1) As tecnologias podem ser incorporadas em sala de aula sem a necessidade de uma infraestrutura avançada? 2) As informações obtidas antes, durante e após a aula podem ser integradas pelos próprios professores de forma que

\footnotetext{
${ }^{33}$ Produto final refere-se ao material educacional multimídia obtido da integração das mídias com o software InMid. Alguns materiais produzidos pelos licenciandos em 2003 se encontram no Anexo B.
} 
seja produzido material educacional digital? 3) Os professores aprendem com o uso da tecnologia?

Com relação à primeira questão, os licenciandos obtiveram bons resultados com mídias do tipo vídeo, áudio, texto, conseguindo armazenar informações das aulas, filmando atividades do cotidiano, considerado por eles uma atividade muito importante do ponto de vista pedagógico. Com relação à segunda questão, o uso do InMid se mostrou uma ferramenta de fácil manuseio e que propiciou esta integração de mídias de maneira considerada muito boa, pelos licenciandos, na produção de material educacional digital. Com relação à terceira questão, os futuros professores destacaram a importância de usar o material educacional digital, produzido com a integração das tecnologias, para refletir sobre a prática pedagógica e na elaboração de situações de aprendizagem.

Os futuros professores que conheceram diversas tecnologias por meio desse trabalho, afirmam que sua aplicação em ambiente educacional pode melhorar o processo de ensino/aprendizagem, desde que as tecnologias sejam usadas adequadamente, o que nos estimula a continuar a sua aplicação na formação de professores. De um modo geral, pode-se concluir que é preciso formar os professores na utilização de novas tecnologias em suas aulas e não apenas colocá-las à sua disposição e informá-los sobre as suas aplicações e benefícios.

\subsection{Perspectivas Futuras}

A metodologia desenvolvida propõe a disseminação do uso de novas tecnologias para a captura de experiências diárias de professores e alunos em sala de aula e para a integração de mídias como apoio ao ensino presencial e à distância, visando a produção de material educacional multimídia. Sendo assim, este trabalho também pode facilitar o posterior oferecimento de cursos à distância, sendo integrado em um ambiente virtual já existente e utilizando os materiais disponíveis. Ficou evidenciada a sua possível aplicação na EAD, pois o material produzido pelos futuros professores na fase de Integração da metodologia pode favorecer a produção de material educacional digital. Esse mesmo material, usufruindo dos recursos de 
transcrição de áudio, pode ser aplicado com alunos com deficiência auditiva e avaliada a sua eficácia.

A metodologia proposta também pode ser empregada pelos alunos na produção de materiais educacionais para diversos fins. Testes podem ser feitos em sala de aula com professores em serviço e seus alunos na utilização desses materiais, obtendo informações a respeito do seu uso e comparando com as observações feitas pelos licenciandos e apresentadas neste trabalho.

Após a realização desta pesquisa e os resultados obtidos, pretende-se que a metodologia desenvolvida também seja aplicada na formação continuada de professores e com professores na ativa, já que em novembro de 2003, foi realizada uma primeira aplicação da metodologia com um professor da rede pública de ensino, em uma escola da cidade de São Carlos, SP (ver Anexo C).

As melhorias sugeridas para o software InMid, durante a aplicação deste trabalho, podem ser implementadas com o desenvolvimento de novas versões. $\mathrm{O}$ código fonte do InMid é aberto e está disponível para futuras alterações, porém padrões do projeto $\mathrm{GNU}^{34}$ podem ser adotados para torná-lo um software livre, sendo executado no sistema operacional GNU/Linux e distribuído através da licença GNUGPL (General Public License).

\footnotetext{
${ }^{34}$ http://www.gnu.org
} 


\section{Anexo A}

Descrição das funcionalidades dos cinco módulos do software InMid e exemplos de documentos SMIL, RealPicture, RealText e HTML gerados pelo software. 


\section{Módulos do Software InMid}

\section{Módulo de Seleção de Mídias}

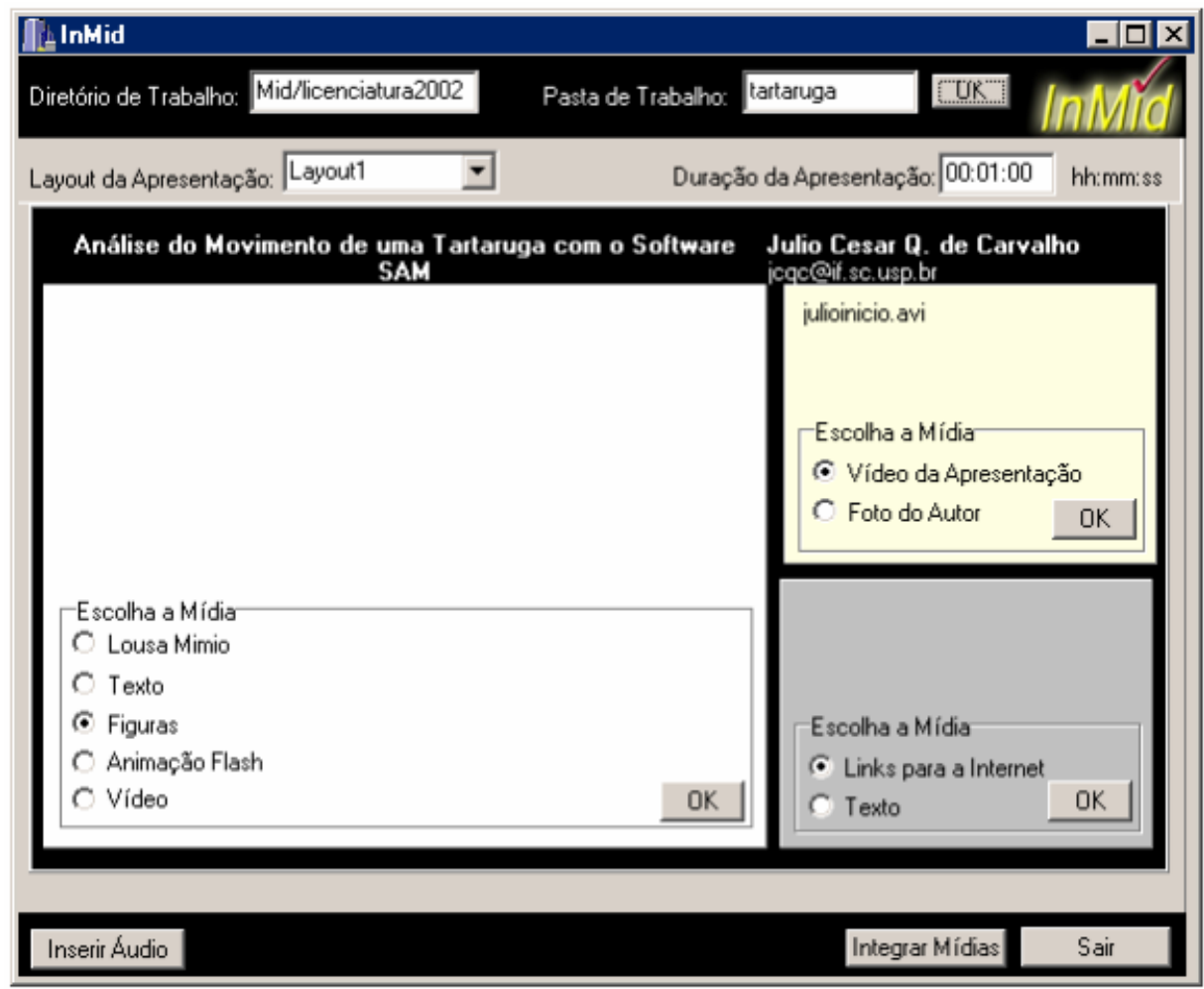

Figura 23 - Módulo de Seleção de Mídias.

A seguir serão descritos os itens que devem ser preenchidos no Modulo de Seleção de Mídias do InMid:

Pasta de Trabalho - Nesse item, o professor informa o nome da pasta de trabalho (ou diretório do projeto). Sugere-se que seja um nome que represente o conteúdo informativo da aula. Deve-se seguir as regras de nomenclatura para a criação de pastas e arquivos no ambiente Windows.

Sub-Pasta - Nesse item, o professor informa o nome da sub-pasta (ou sub-diretório) que estará localizada dentro da pasta de trabalho e conterá todos os arquivos gerados pelo InMid. Sugere-se que seja um nome que represente informações sobre a aula, pois além de identificar a sub-pasta, esse nome também será adotado nos arquivos gerados pelo sistema, por isso, deve-se seguir as mesmas 
regras de nomenclatura para a criação de pastas e arquivos no ambiente Windows. Se já existir um arquivo de aula com as mídias integradas, o InMid trará toda a configuração com os dados das mídias.

Layout da Apresentação - Nessa opção, o professor pode escolher um dentre quatro diferentes layouts para a elaboração de um material multimídia.

Duração da Apresentação - Nessa opção, é informada a duração da aula. O professor precisa atentar-se no tempo de duração do Vídeo da Apresentação, das informações obtidas da Lousa Mimio e da animação dos slides selecionados na opção Figuras.

Vídeo da Apresentação ou Foto do Autor - A escolha desta mídia implica na identificação do professor da aula, podendo ser exibido um vídeo gravado durante uma aula ministrada ou a foto do professor. Esta mídia tem que ter resolução máxima de 170x130 pixels, para ser visualizada em sua totalidade.

Links para a Internet ou Texto - A mídia escolhida poderá formar um menu de itens com links para a Internet ou apresentar um texto estático com informações do professor, ou um texto animado simultaneamente com o áudio, ou ainda, um texto animado contendo a transcrição do áudio para deficientes auditivos, por exemplo.

Lousa Mímio, Texto, Figuras, Animação Flash ou Vídeo - Se opção “Mimio”, informar o nome do arquivo gerado pelo software do Mimio, contendo as informações armazenadas na lousa durante a aula, com extensão MBC; se “Texto”, será acionado o Módulo Edição de Texto, no qual o professor poderá optar por ser animado ou não; se “Figuras”, será acionado o Módulo Inserção de Figuras, na qual o professor poderá exibir uma seqüência de slides do PowerPoint com um tempo de transição entre um slide e outro; se “Animação Flash”, informar o nome do arquivo de animação com extensão SWF (ShockWave File); e se opção “Vídeo”, informar o nome do arquivo de vídeo. Esta opção é ideal para um vídeo com maior resolução mostrando uma aula de software que exige a visualização de detalhes maiores, por exemplo. Neste ponto, é importante que o professor conheça previamente as mídias através de um treinamento no uso de cada uma delas. A resolução para as figuras, geradas pelo PowerPoint ou pelo software do Mimio ou a resolução do vídeo devem ser de no máximo 480x360 pixels.

Título, Nome do Autor e E-mail - Informações sobre o Título, Nome 
do Autor e E-mail, são digitadas no próprio local, sendo selecionadas com um “clic” do mouse. As respectivas cores, bem como a cor de fundo, podem ser escolhidas pelo professor.

Inserir Áudio - Se a aula tiver áudio gravado, separadamente, selecionar o botão “Inserir Áudio”. Informar o nome do arquivo de áudio e o idioma.

Integrar Mídias - Este botão integra as mídias previamente selecionadas pelo professor, em segundos. Se alguma mídia, que estiver dentro de uma das três janelas “Escolha a Mídia” não for selecionada, será exibido um aviso e não será feita a integração, até que todos os itens de "Escolha de Mídias” sejam selecionados.

\section{Módulo de Edição de Itens de Menu}

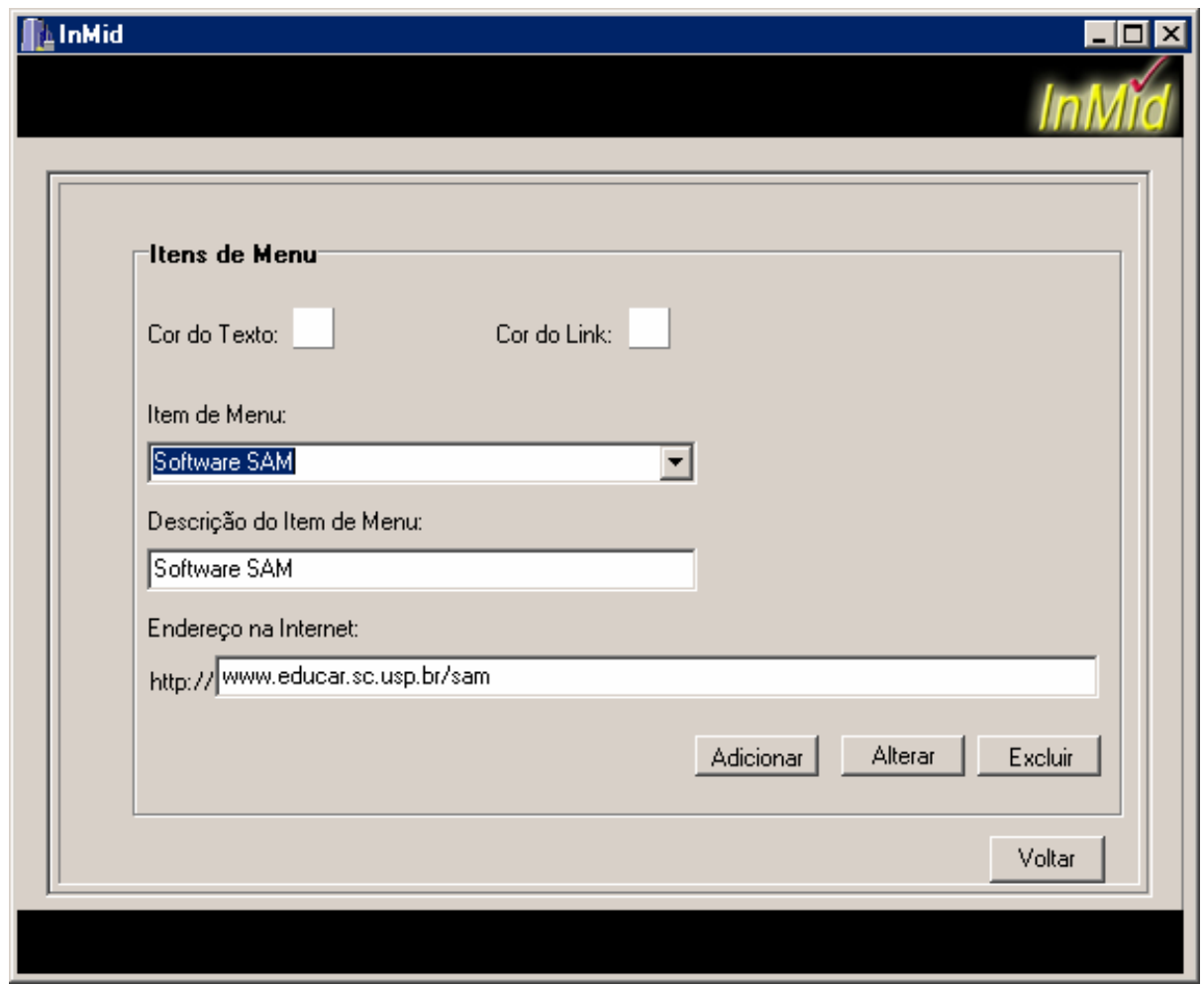

Figura 24 - Módulo de Edição de Itens de Menu (Links para a Internet).

Se a mídia escolhida for “Links para a Internet”, será acionado o Módulo de Edição de Itens de Menu. Neste Módulo, o professor deve informar a cor do texto e do Link, criar um item de menu, informar a descrição e o endereço da Internet para o item criado. Os botões “Adicionar”, “Alterar” e "Excluir”, adicionam, alteram e excluem, respectivamente, um Item de Menu. Primeiramente, o professor deve escolher o item desejado e depois acionar esses botões. O botão "Voltar", retorna ao 
Módulo principal.

\section{Módulo de Edição de Texto de Menu}

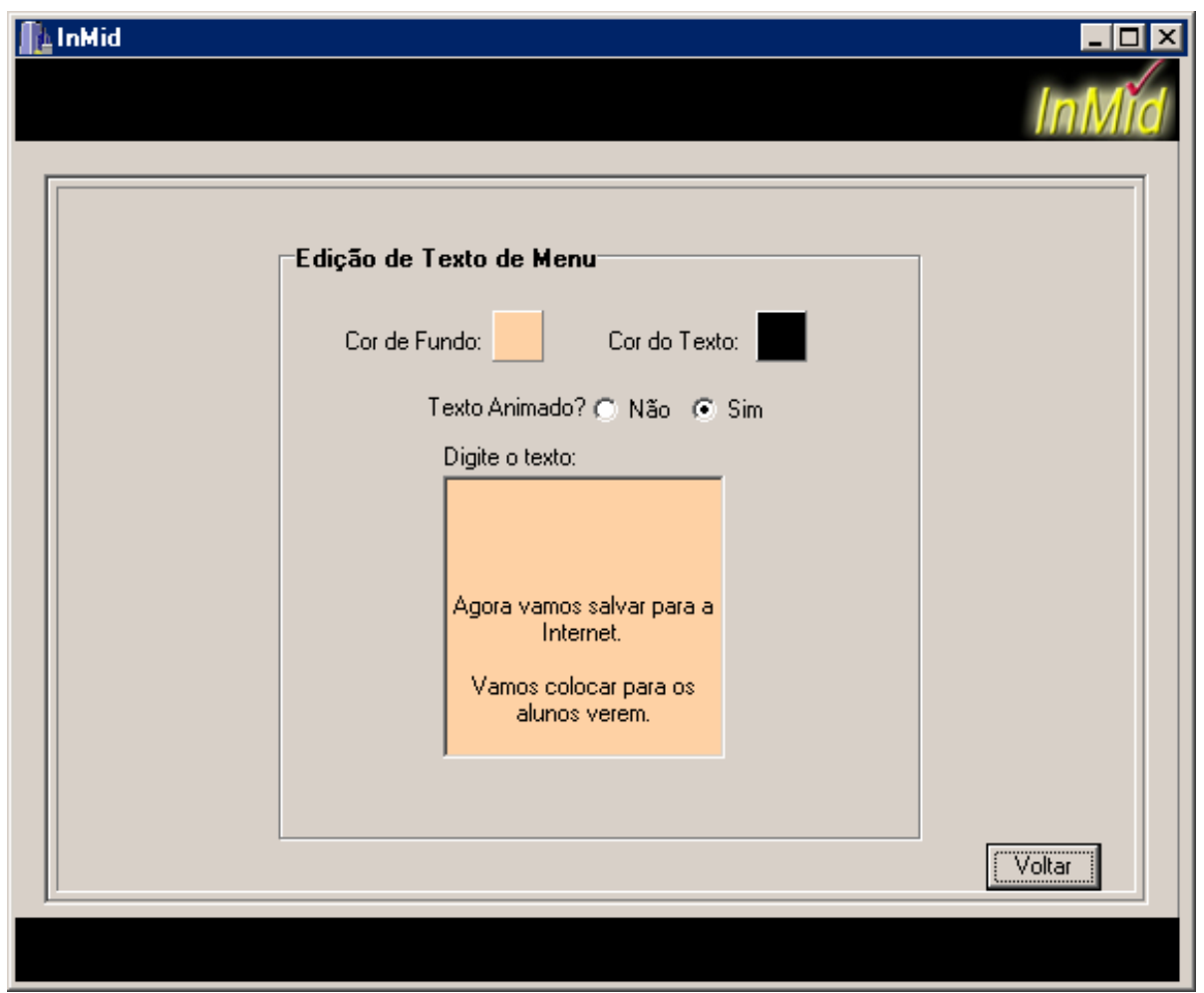

Figura 25 - Módulo de Edição de Texto de Menu, opção Texto Animado.

Se a mídia escolhida for "Texto” dentre as opções "Links para a Internet e Texto”, será acionado o Módulo de Edição de Texto de Menu. Neste Módulo, o professor deve informar a cor do fundo, a cor do texto, se o texto será animado e, finalmente, digitá-lo. A janela da figura 25 simula o tamanho original da janela que aparecerá no material multimídia. O botão “Voltar”, retorna ao Módulo principal. 


\section{Módulo de Inserção de Figuras}

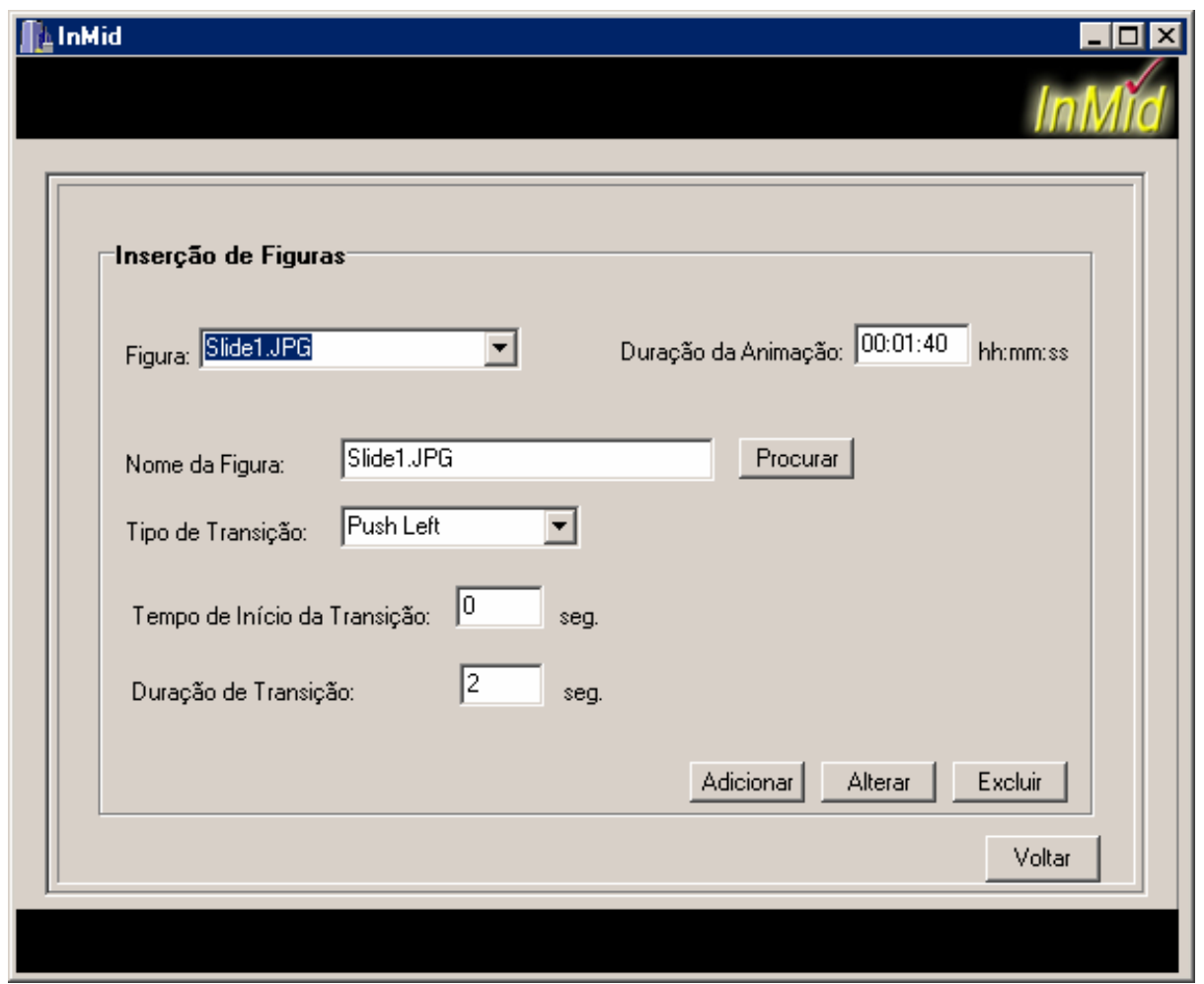

Figura 26 - Módulo de Inserção de Figuras.

Se a mídia escolhida for “Figuras”, será acionado o Módulo de Inserção de Figuras. Neste Módulo, o professor deve informar o nome da figura, que pode ser o nome do seu arquivo; informar a duração da animação, o arquivo que contém a figura, podendo utilizar o botão "Procurar" para localizá-lo; informar o tipo de transição entre uma figura e outra; o tempo de início da transição e a duração da transição. A duração da animação é a soma do tempo total da transição de todas as figuras. Deve ser deixado um tempo maior entre a duração da transição de uma figura e o início da transição da outra. Os botões “Adicionar”, "Alterar” e "Excluir” possuem as mesmas funções do Módulo de Edição de Itens de Menu, já apresentado. O botão "Voltar”, retorna ao Módulo principal. 


\section{Módulo de Edição de Texto}

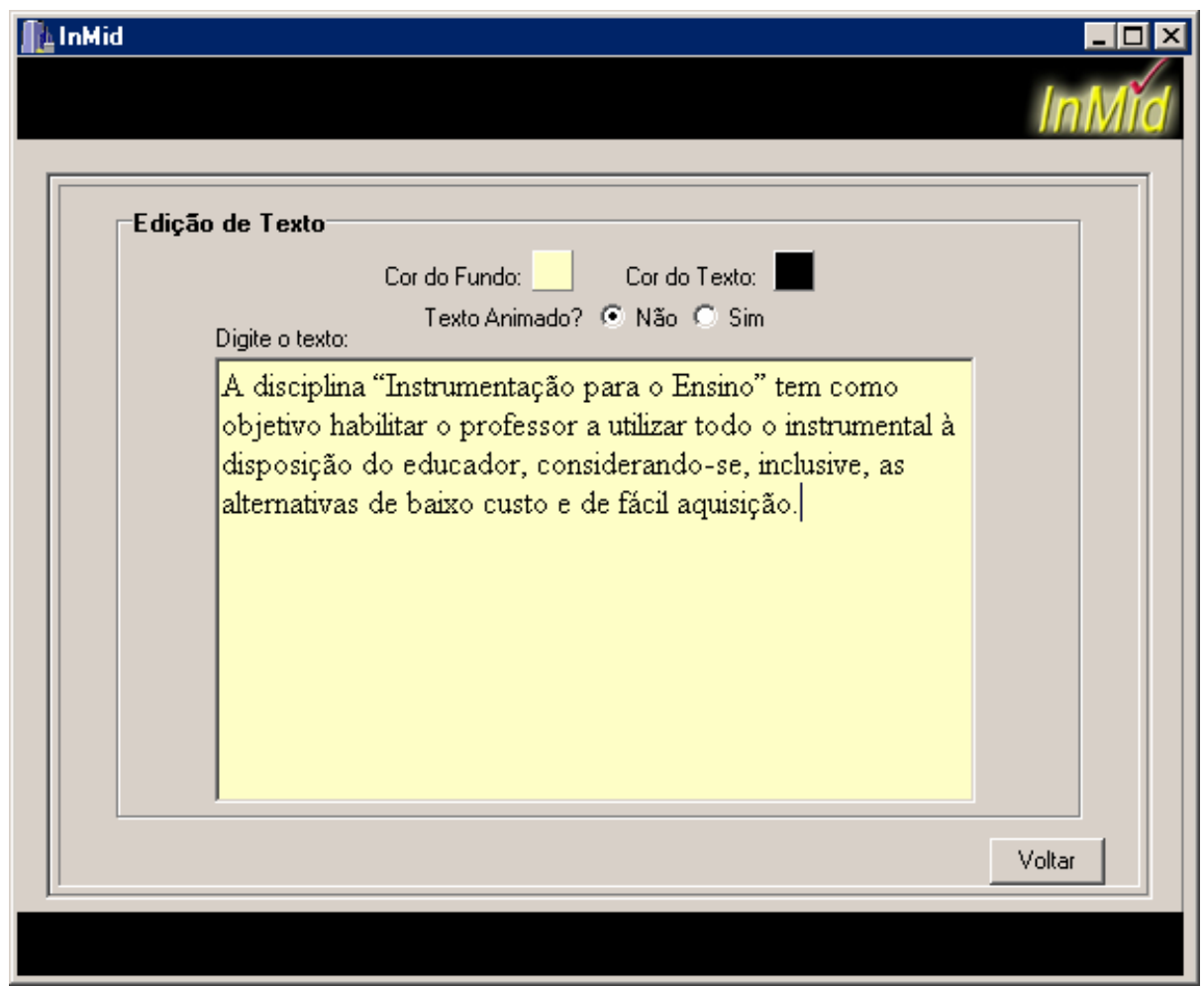

Figura 27 - Módulo de Edição de Texto.

Se a mídia escolhida for “Texto” dentre as opções “Lousa Mímio, Texto, Figuras, Animação Flash ou Vídeo”, será acionado o Módulo de Edição de Texto. Este Módulo é similar ao Módulo de Edição de Texto de Menu, onde o professor deve informar a cor do fundo e do texto, se este será animado e, finalmente, digitá-lo. A janela da figura 27 também simula o tamanho original da janela que aparecerá no material multimídia. O botão "Voltar”, retorna ao Módulo principal. 


\section{Arquivos gerados pelo InMid}

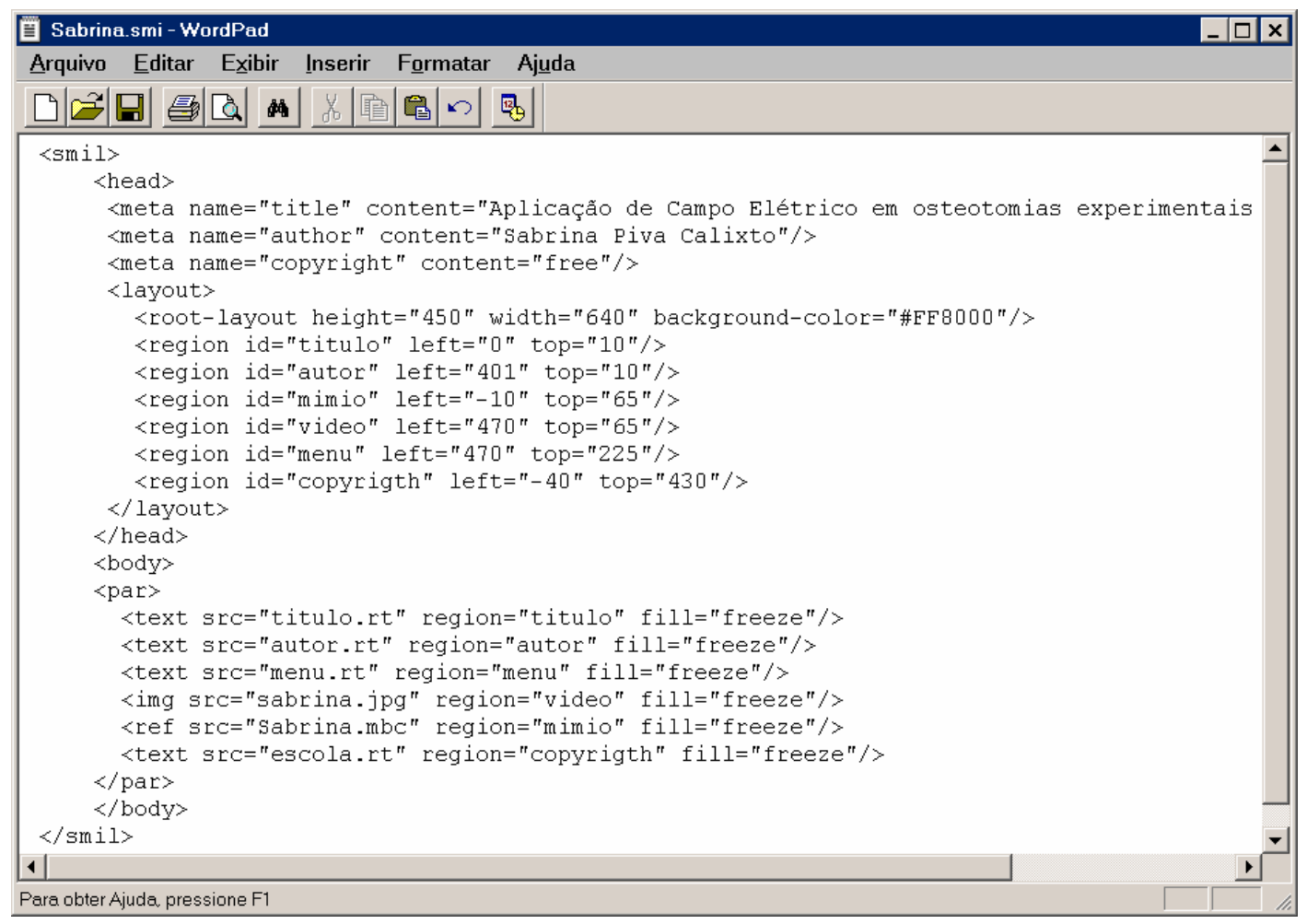

Figura 28 - Exemplo de documento SMIL gerado pelo InMid.

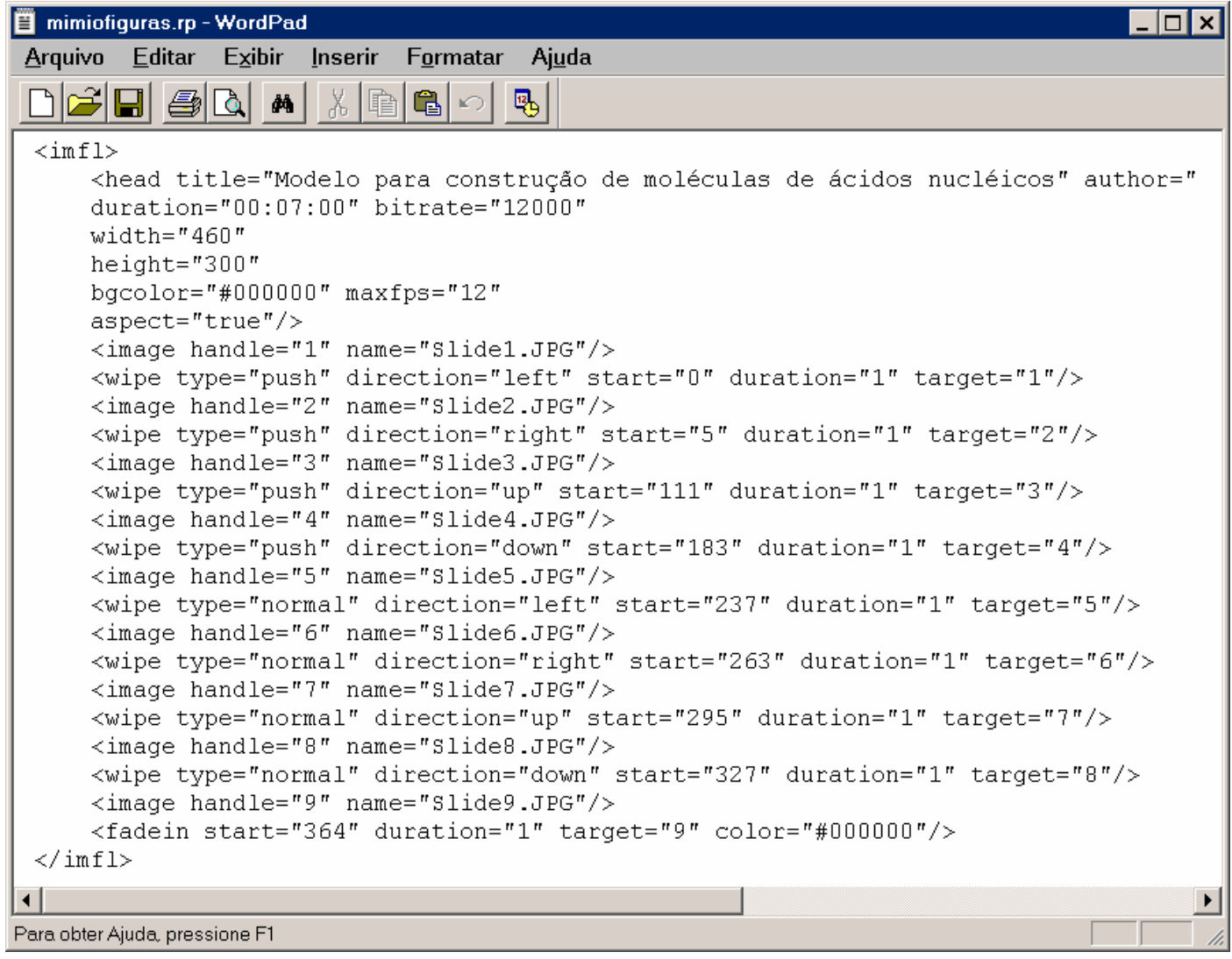

Figura 29 - Exemplo de arquivo RP gerado pelo InMid. 


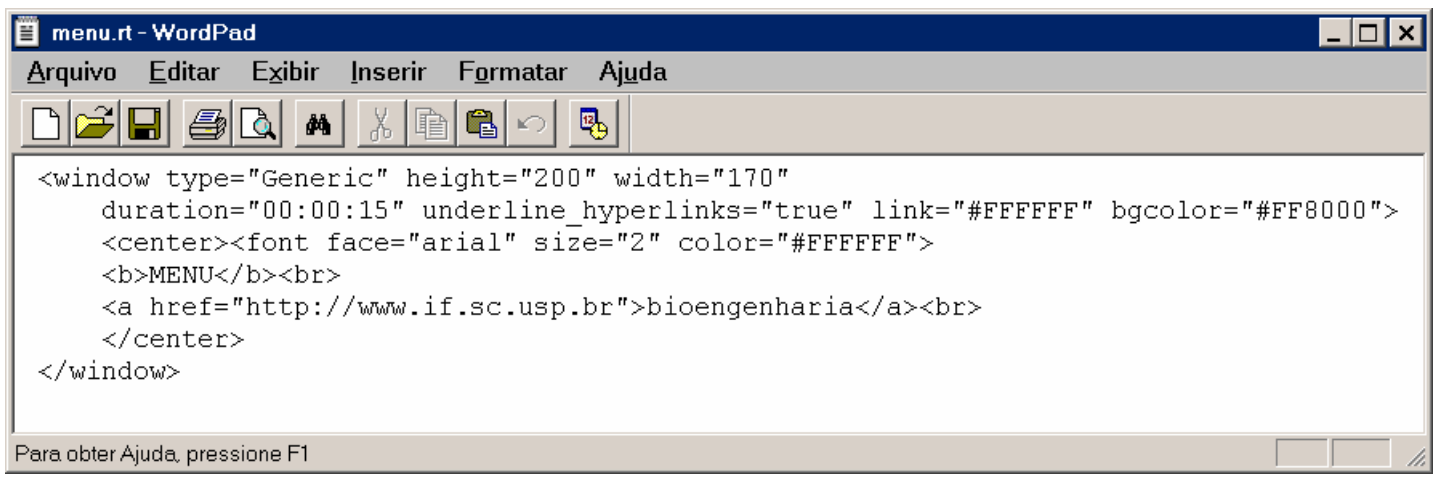

Figura 30 - Exemplo de arquivo RT gerado pelo InMid.

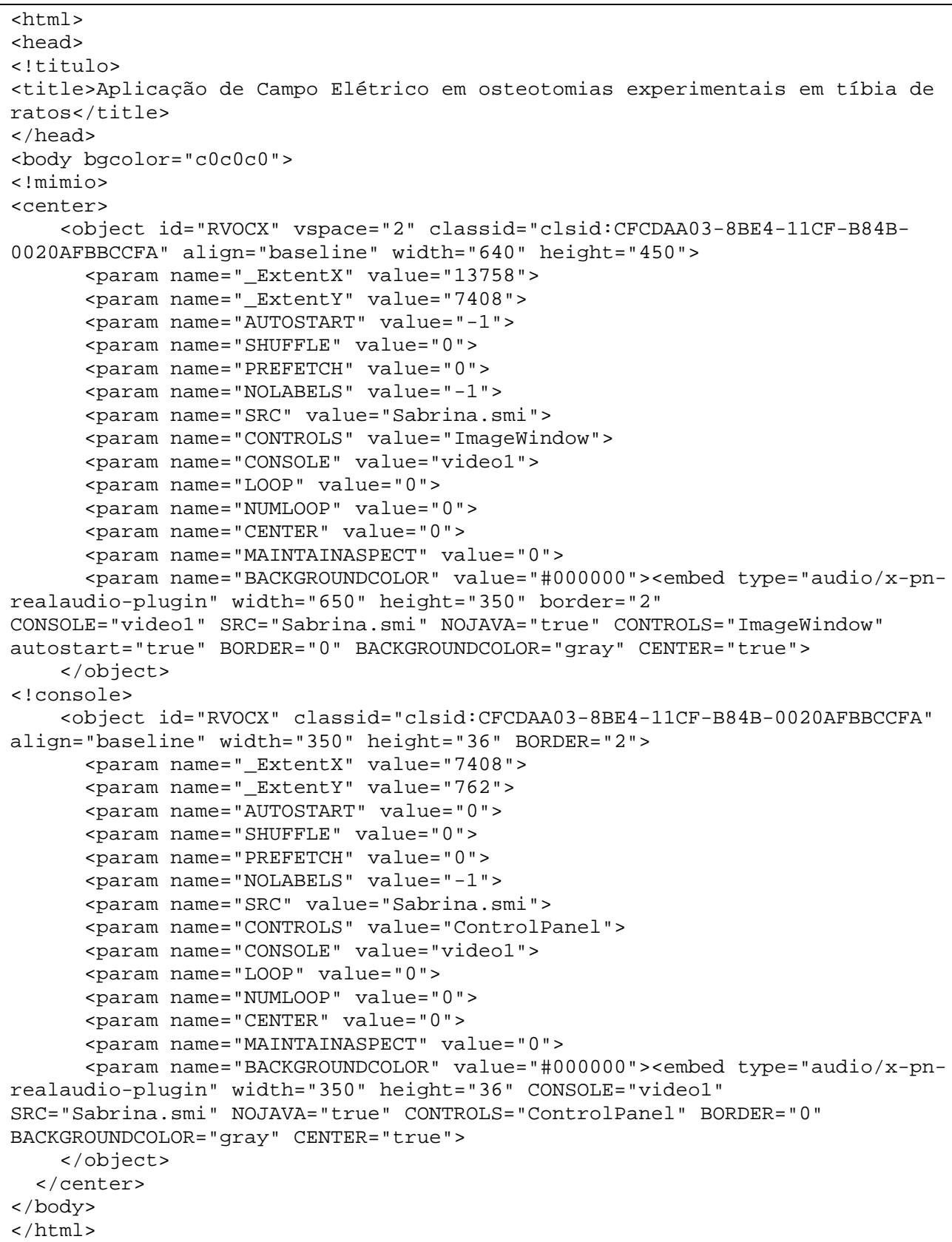

Figura 31 - Exemplo de documento HTML gerado pelo InMid. 


\section{Anexo B}

Alguns materiais educacionais produzidos pelos futuros professores, em 2003, utilizando o InMid na fase de Integração da metodologia proposta neste trabalho, durante a disciplina "Instrumentação para o Ensino", do curso de Licenciatura em Ciências Exatas da USP/São Carlos. 

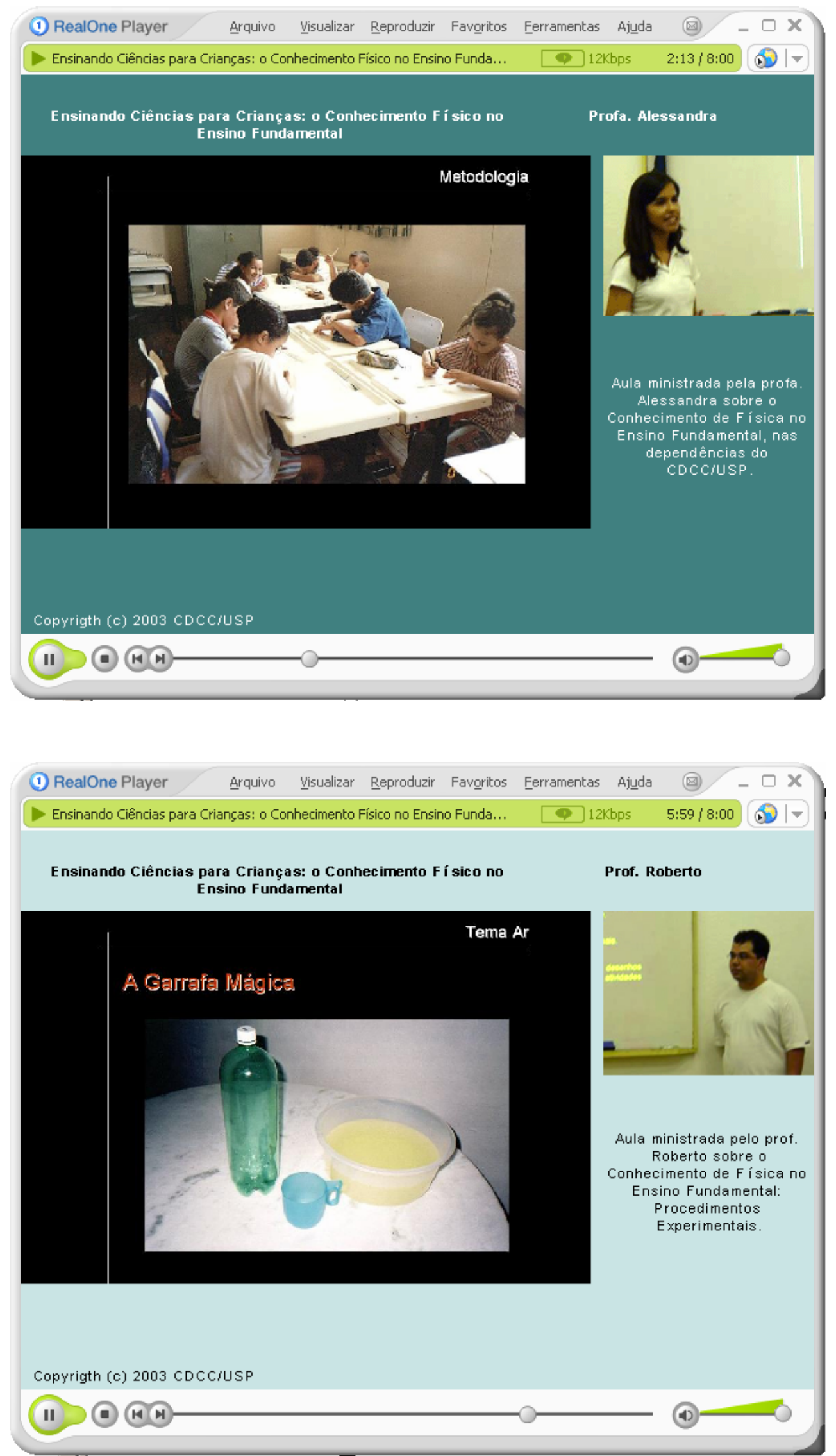

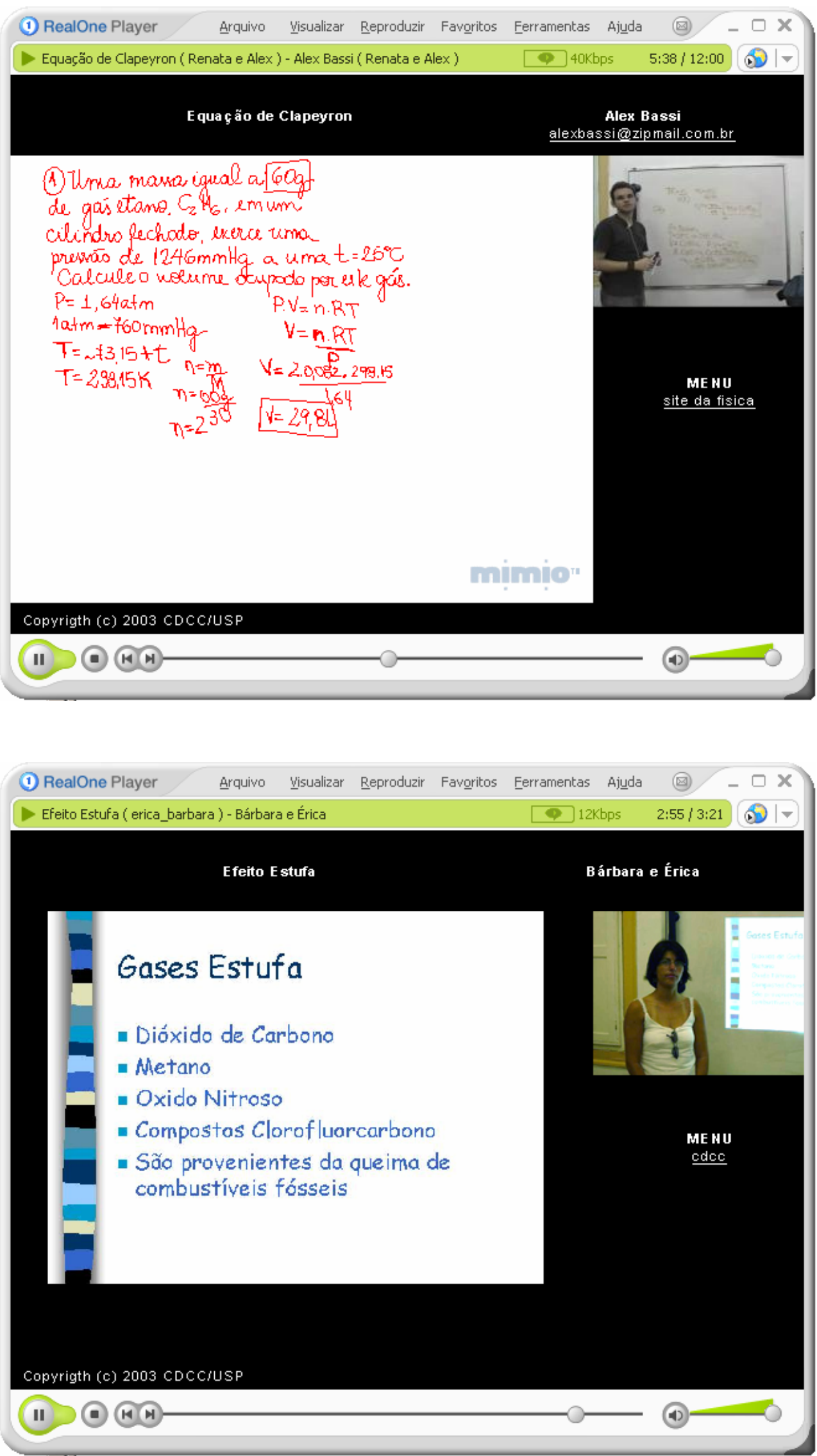

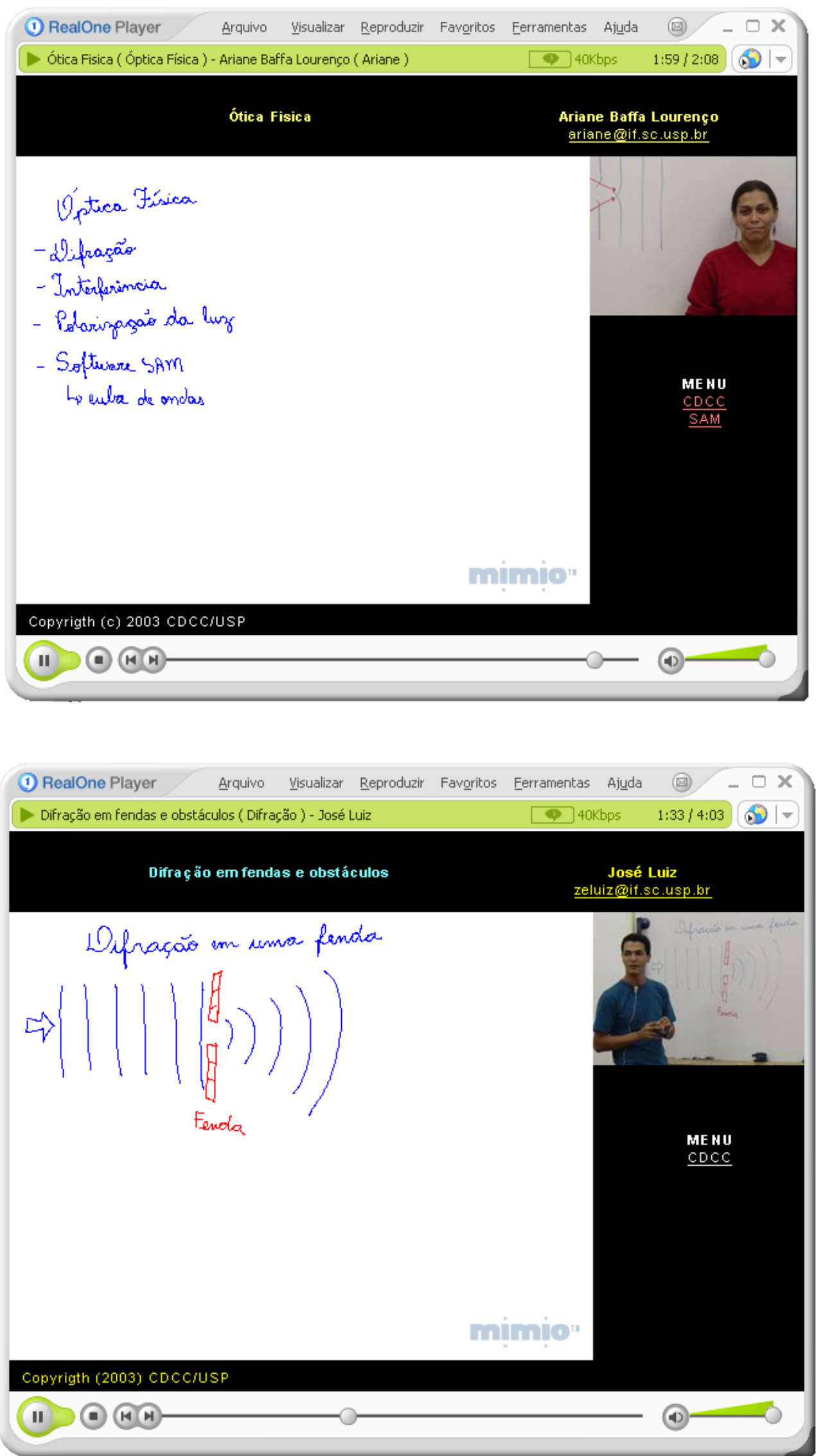

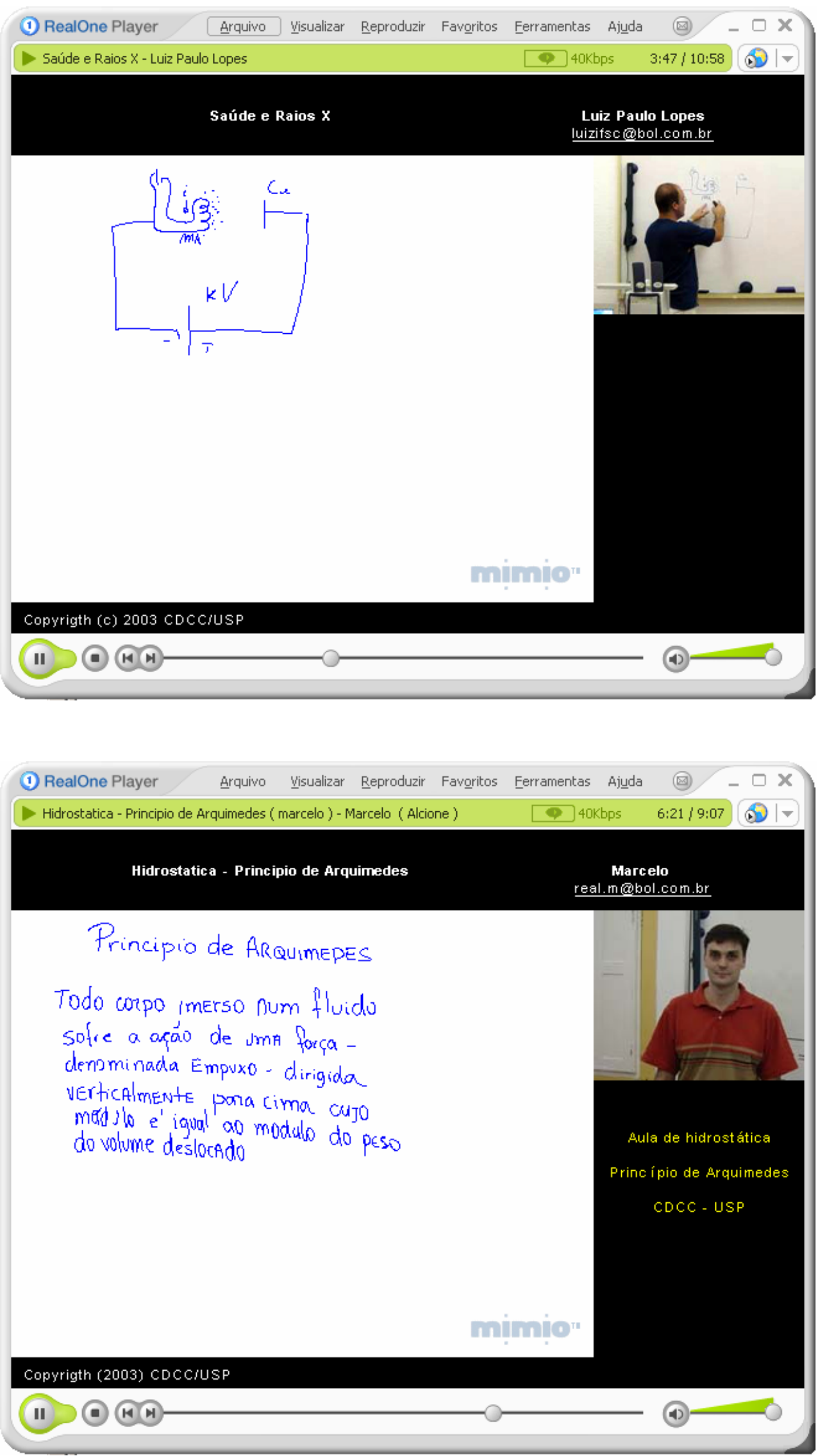

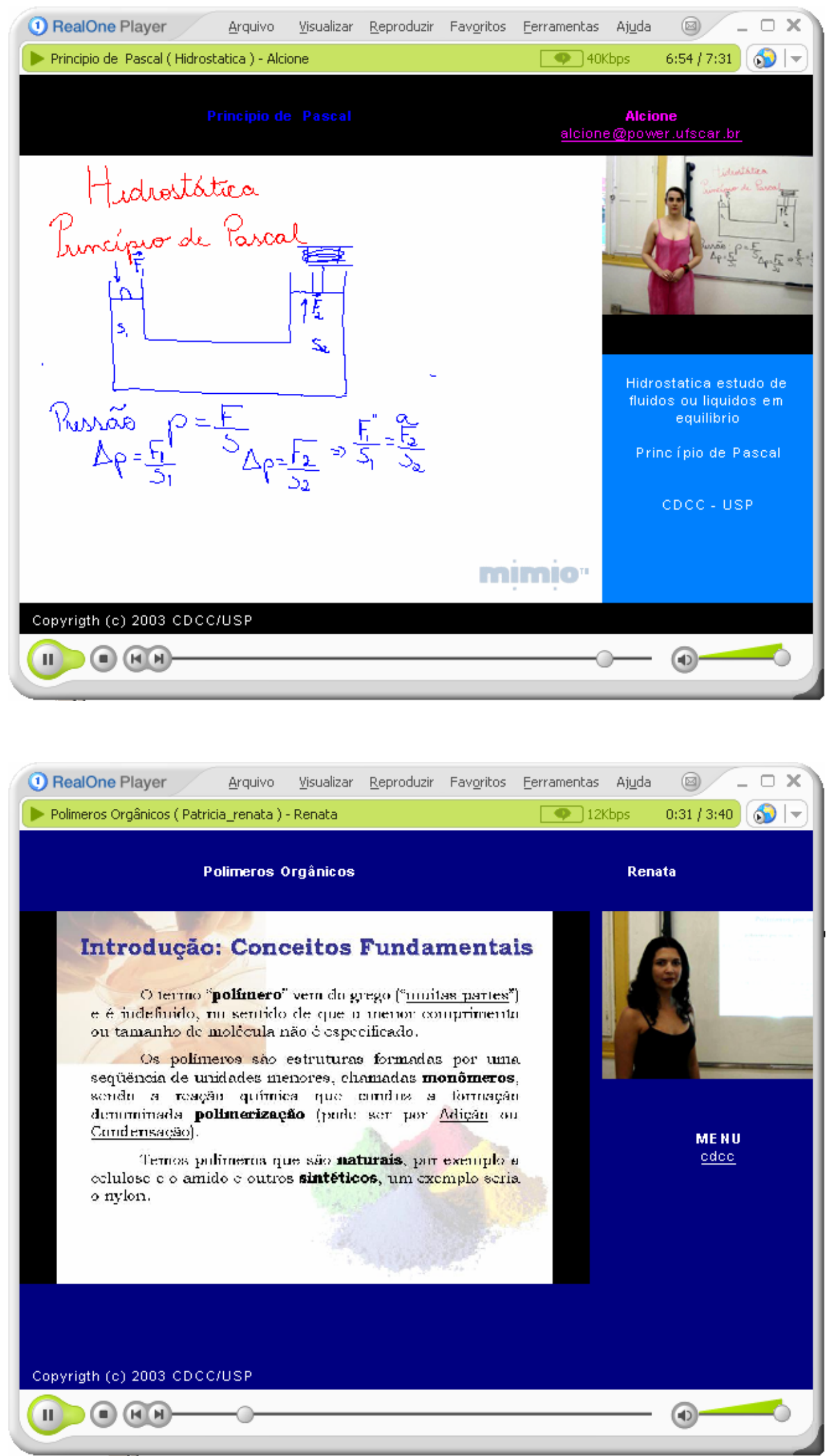

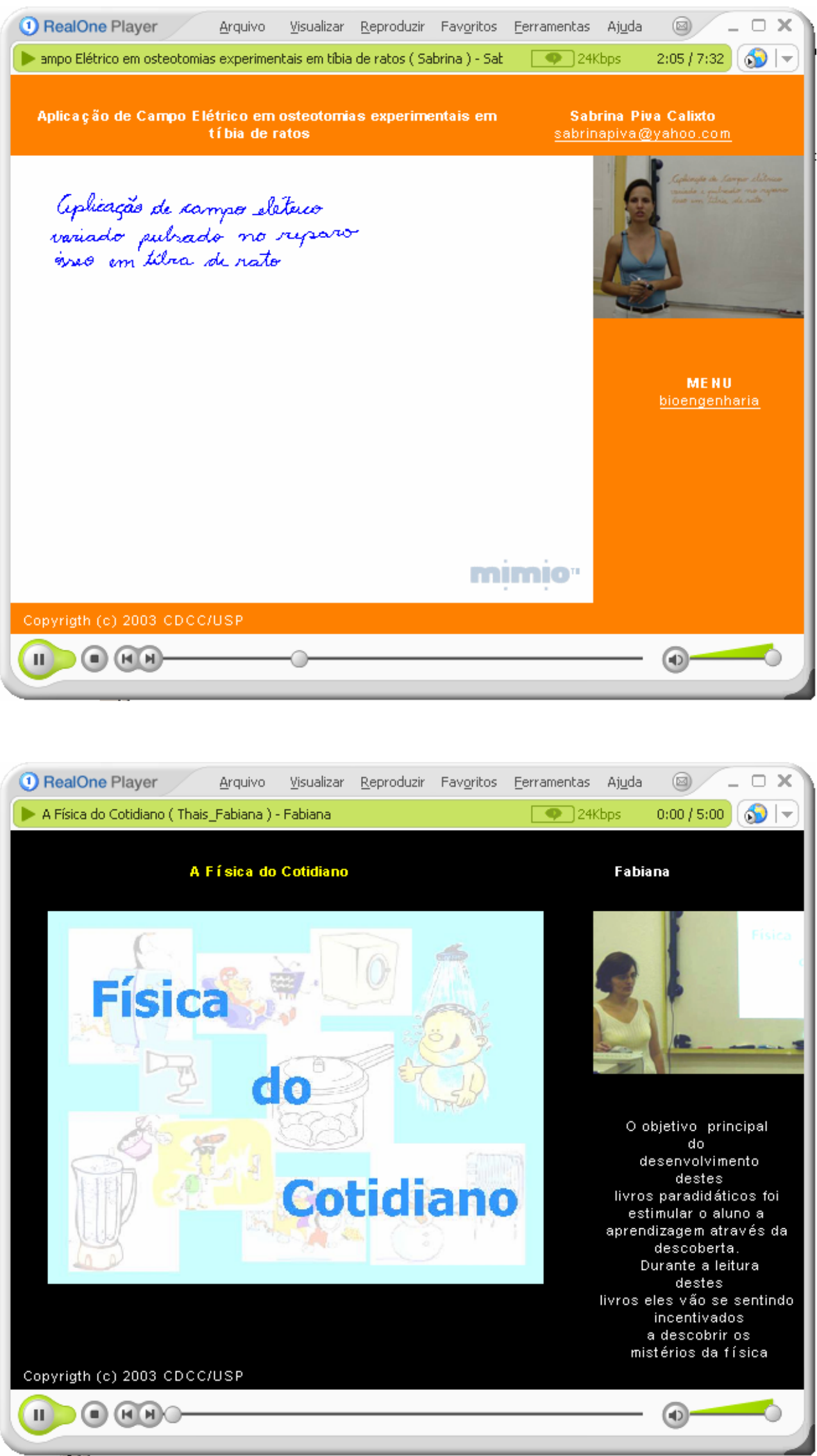

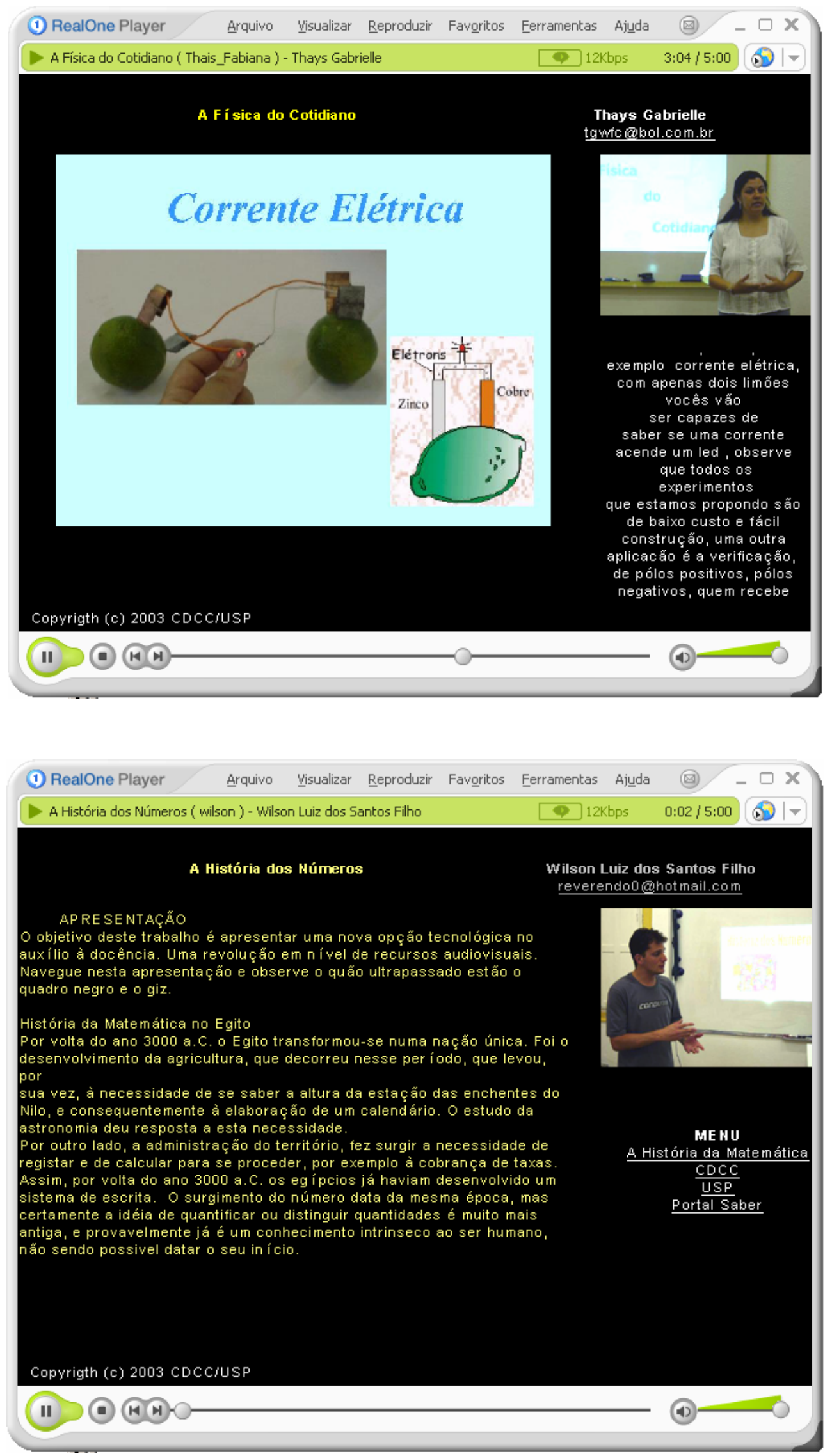
A seguir são apresentados exemplos de páginas HTML elaboradas pelos licenciandos, durante o curso de Licenciatura, em 2003.
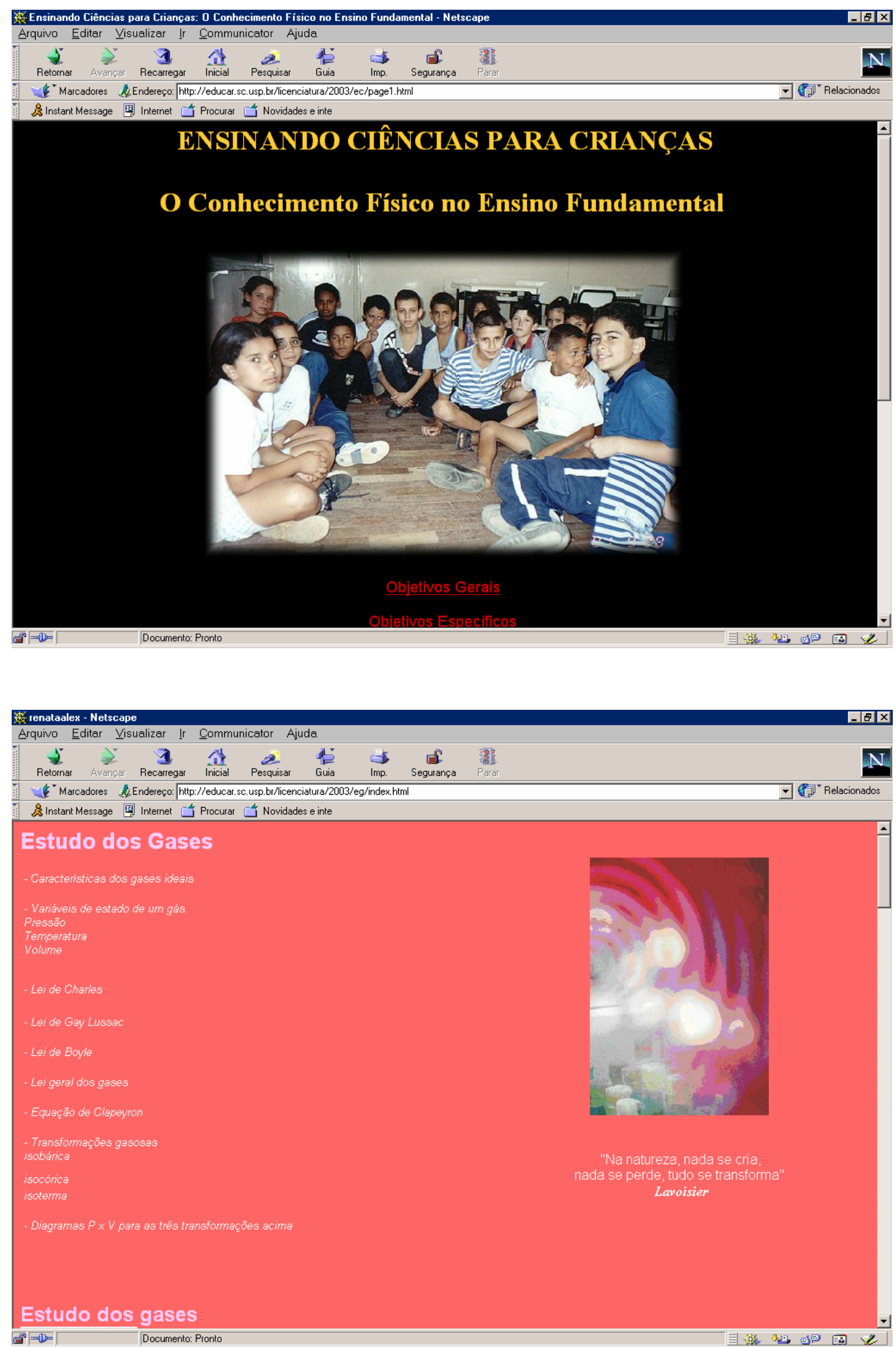

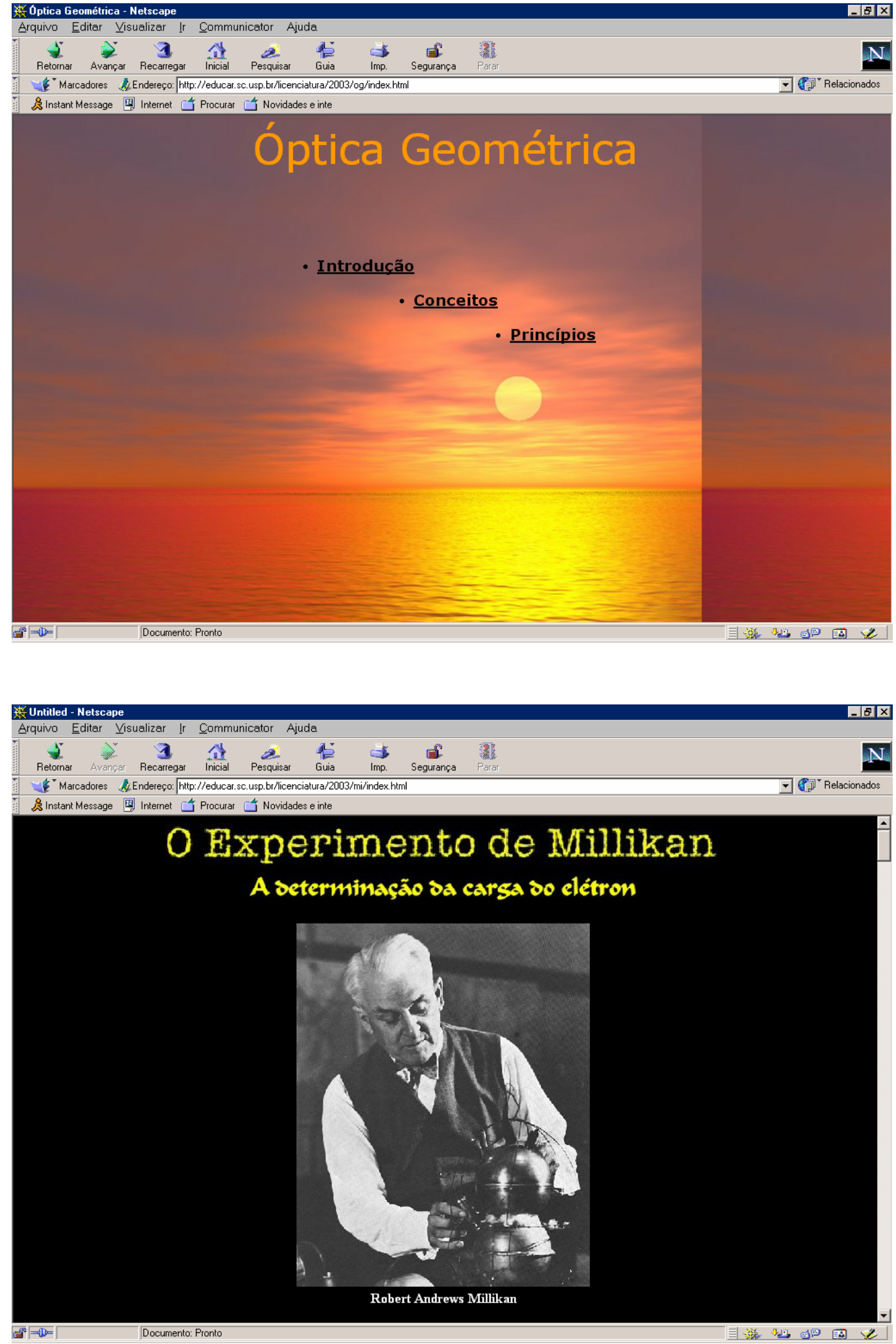

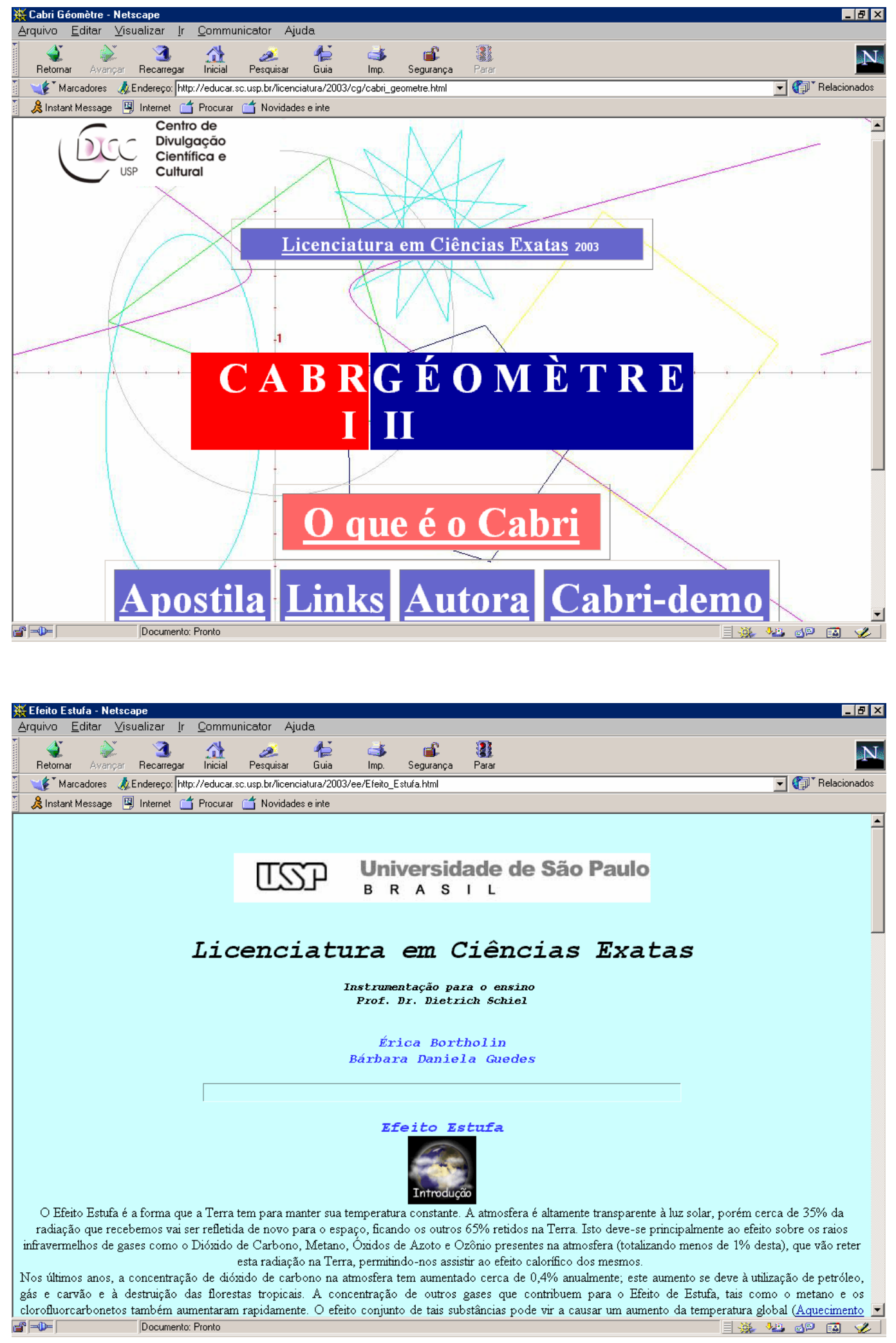

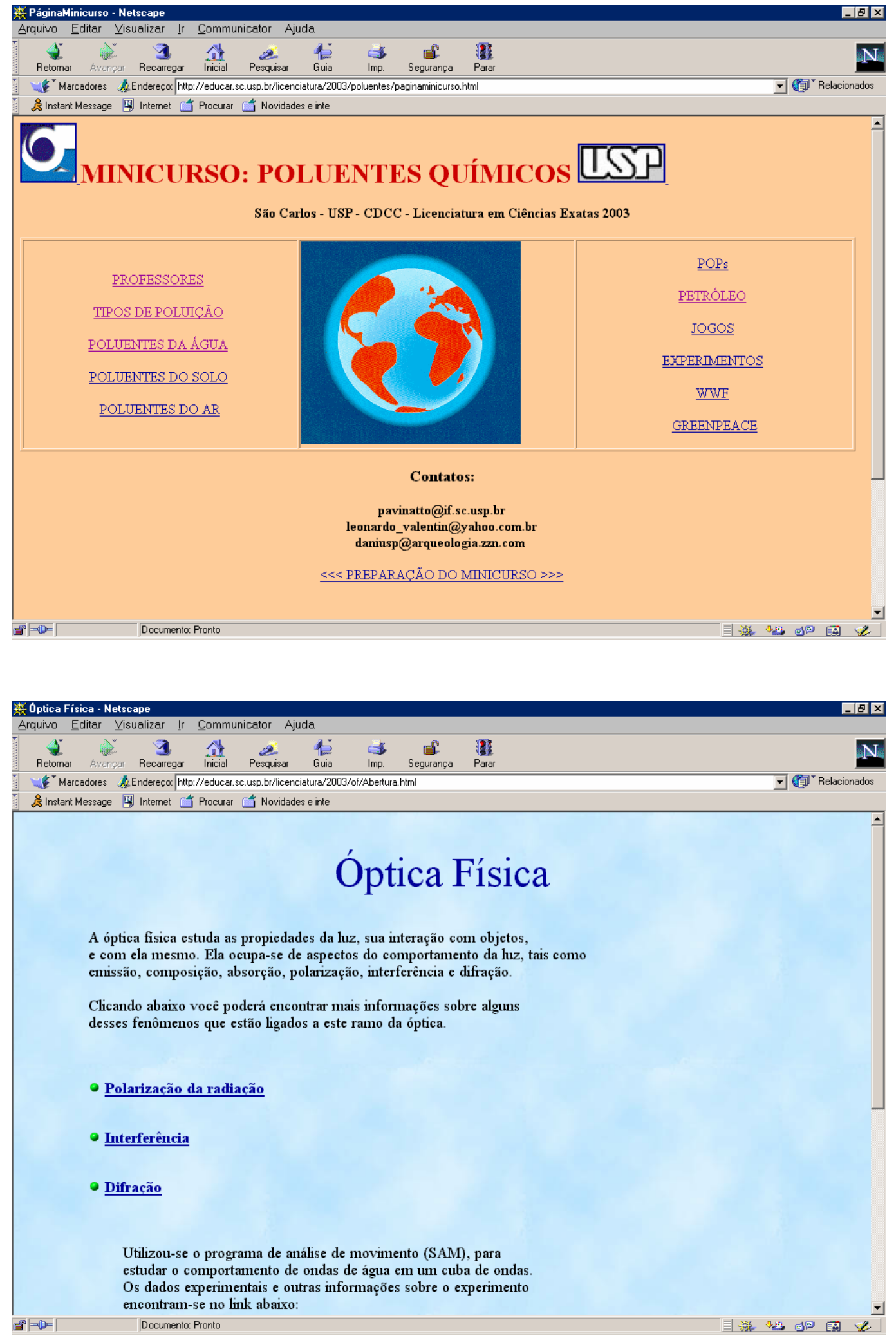


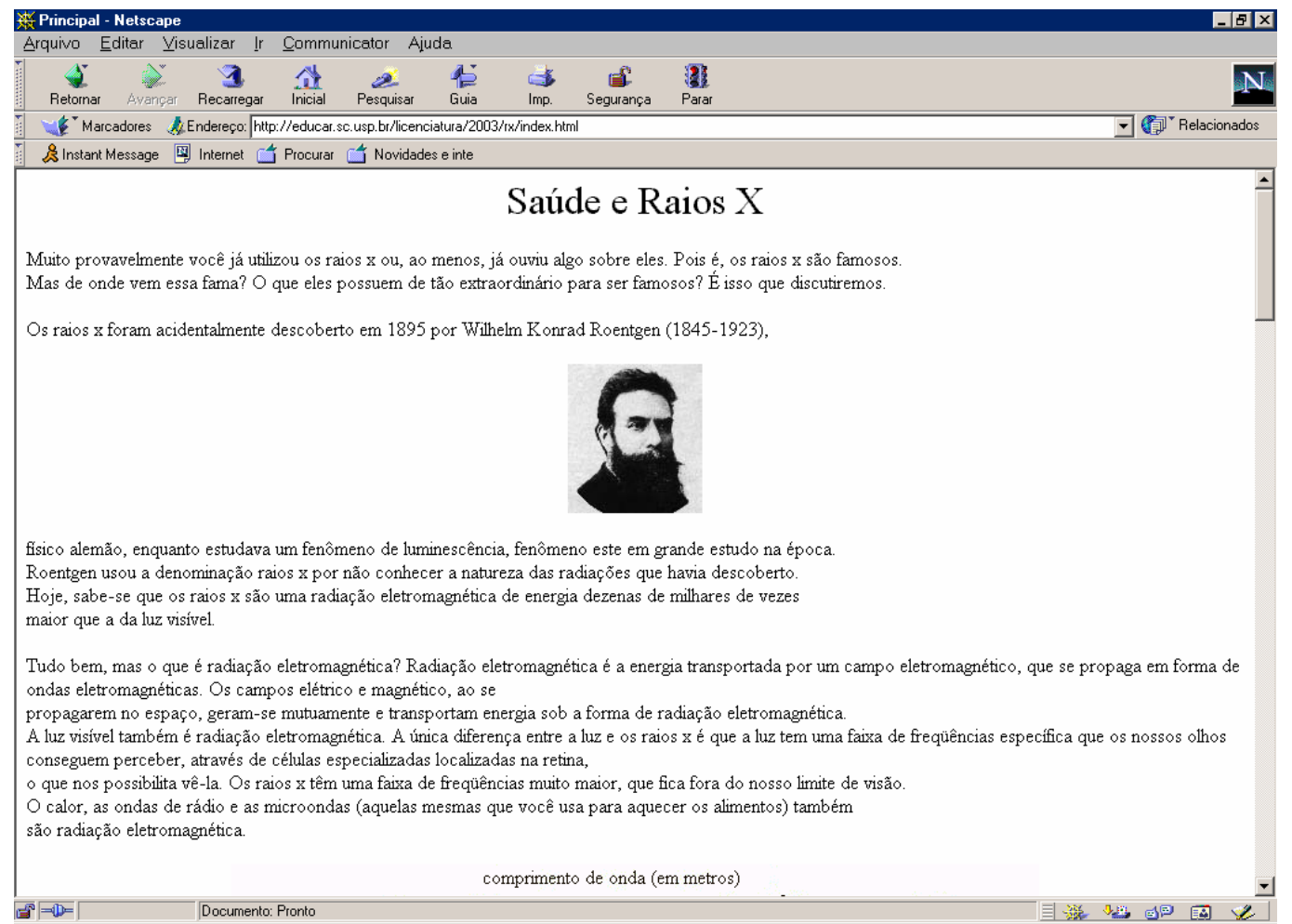

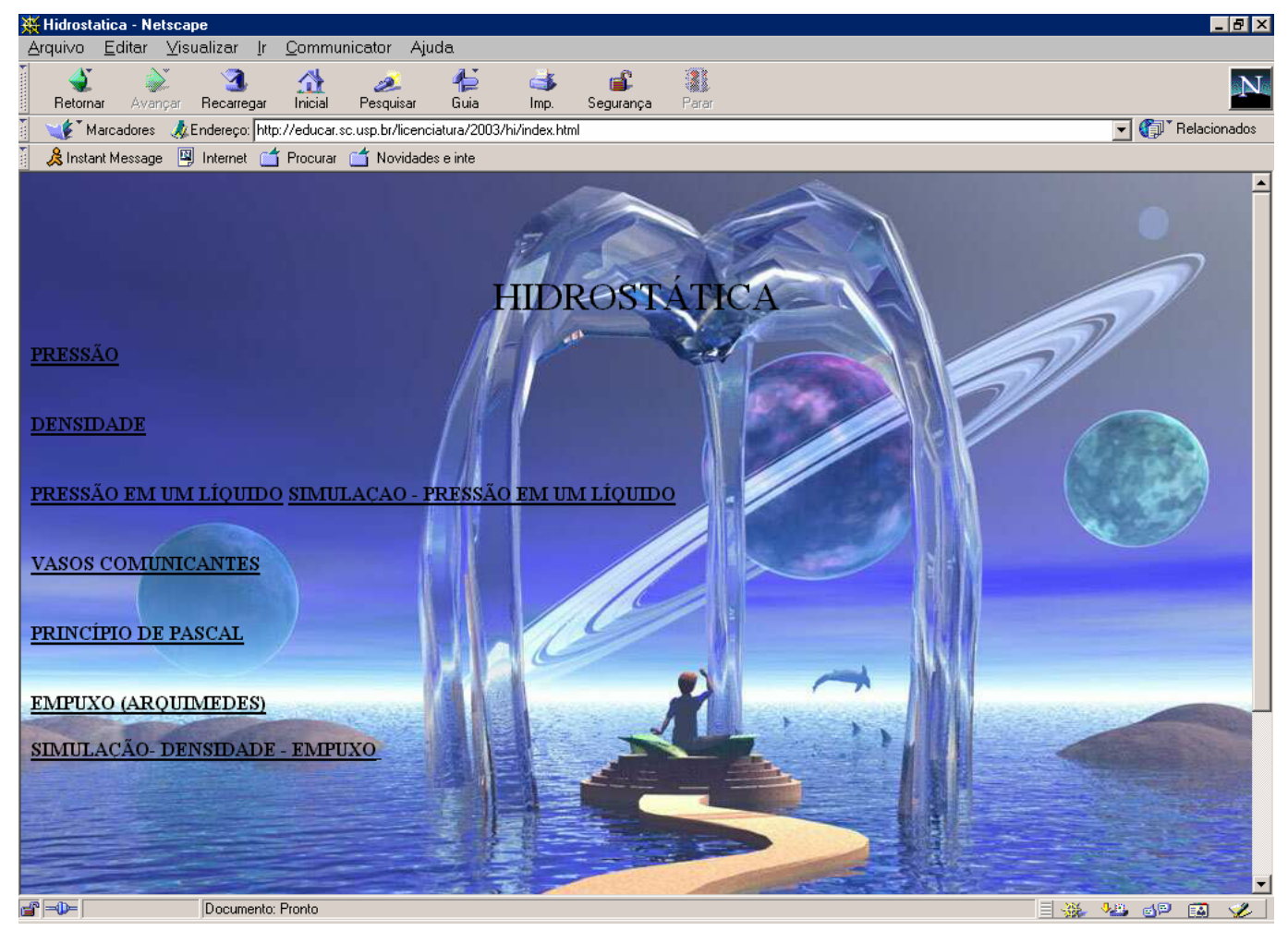



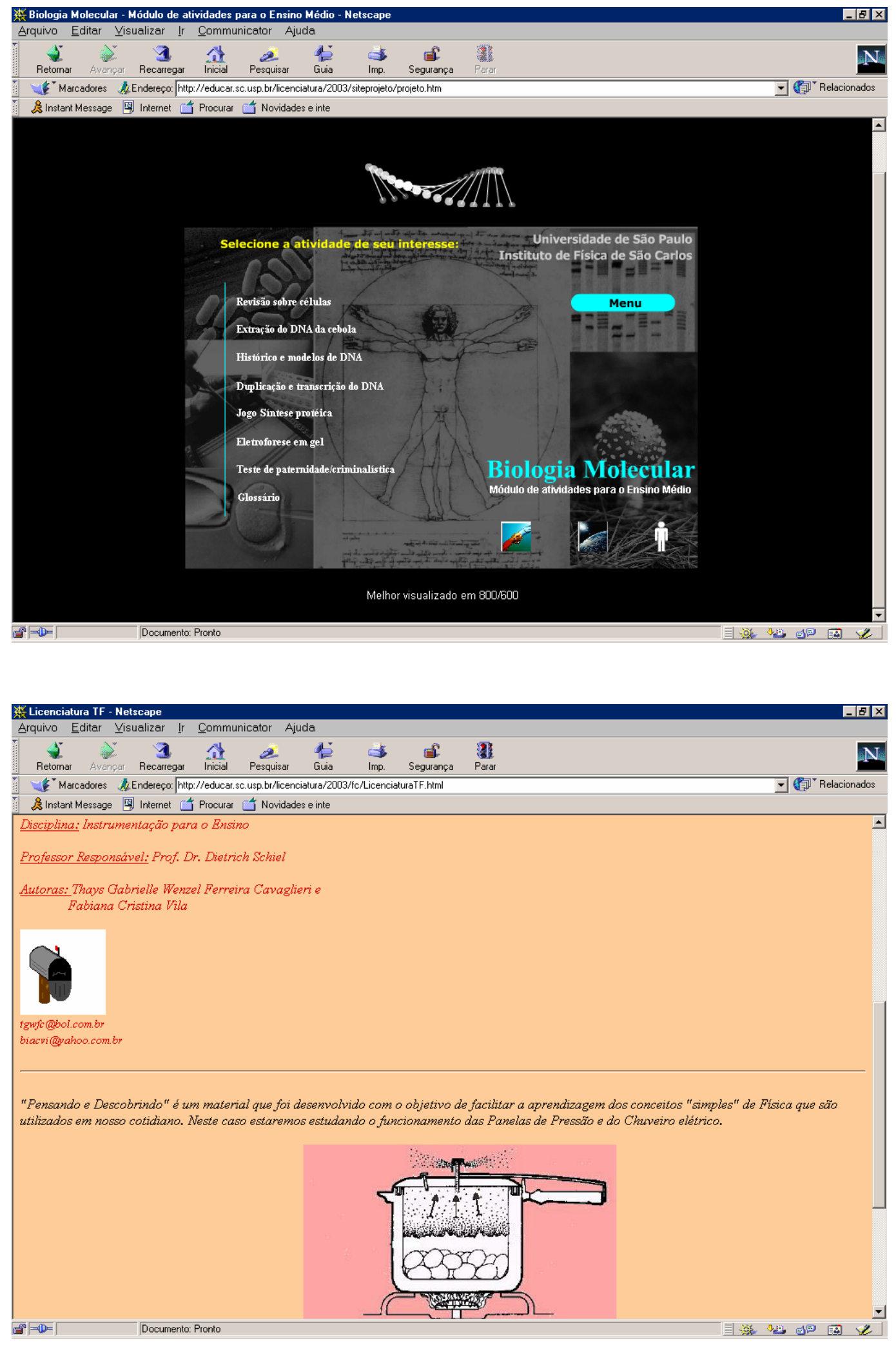


\section{Anexo C}

Primeira aplicação da metodologia com o trabalho de um professor da Escola Estadual Conde do Pinhal, na cidade de São Carlos, SP, em uma aula de Física do Ensino Médio. 


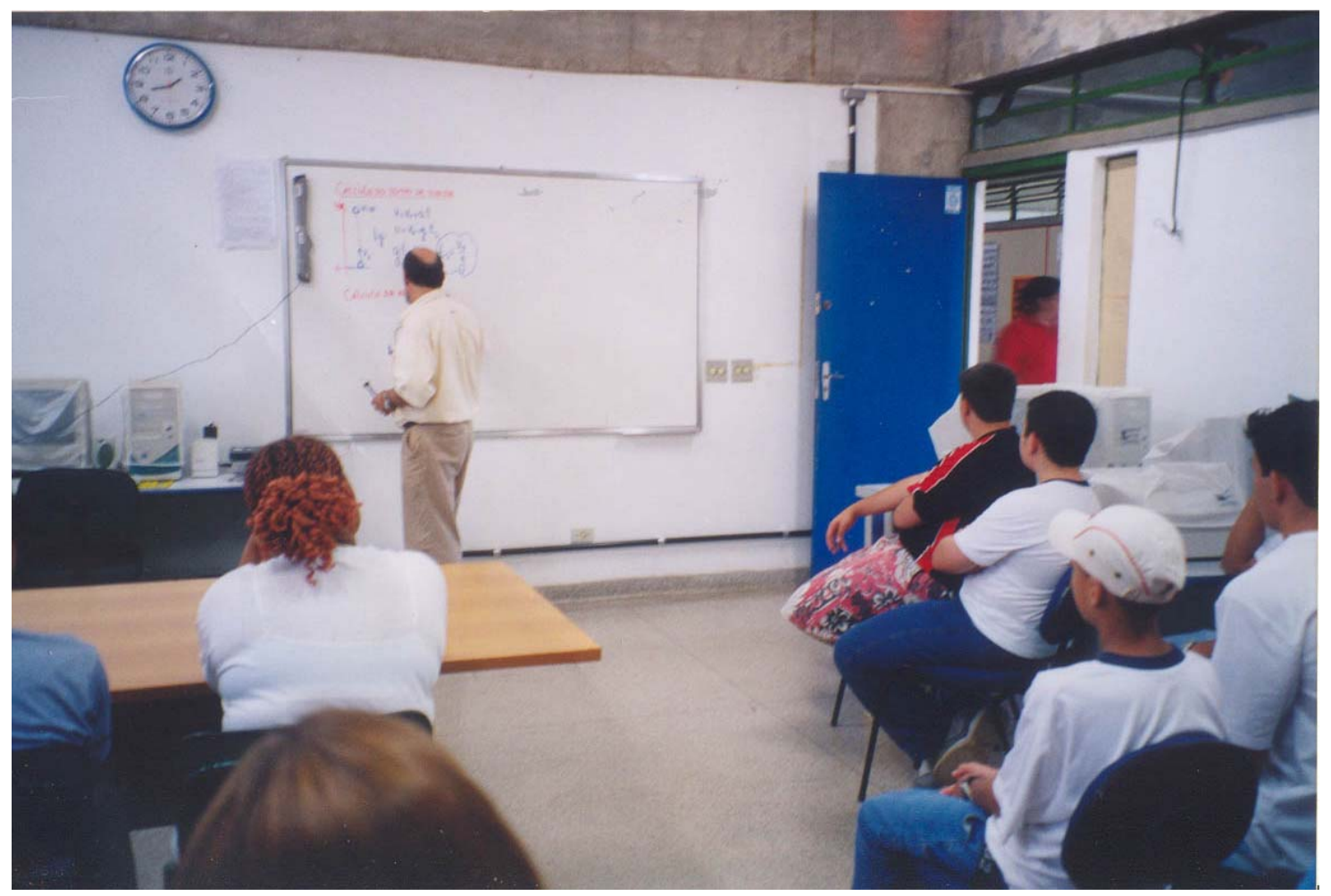

Aplicação da metodologia por um professor de Física do Ensino Médio.

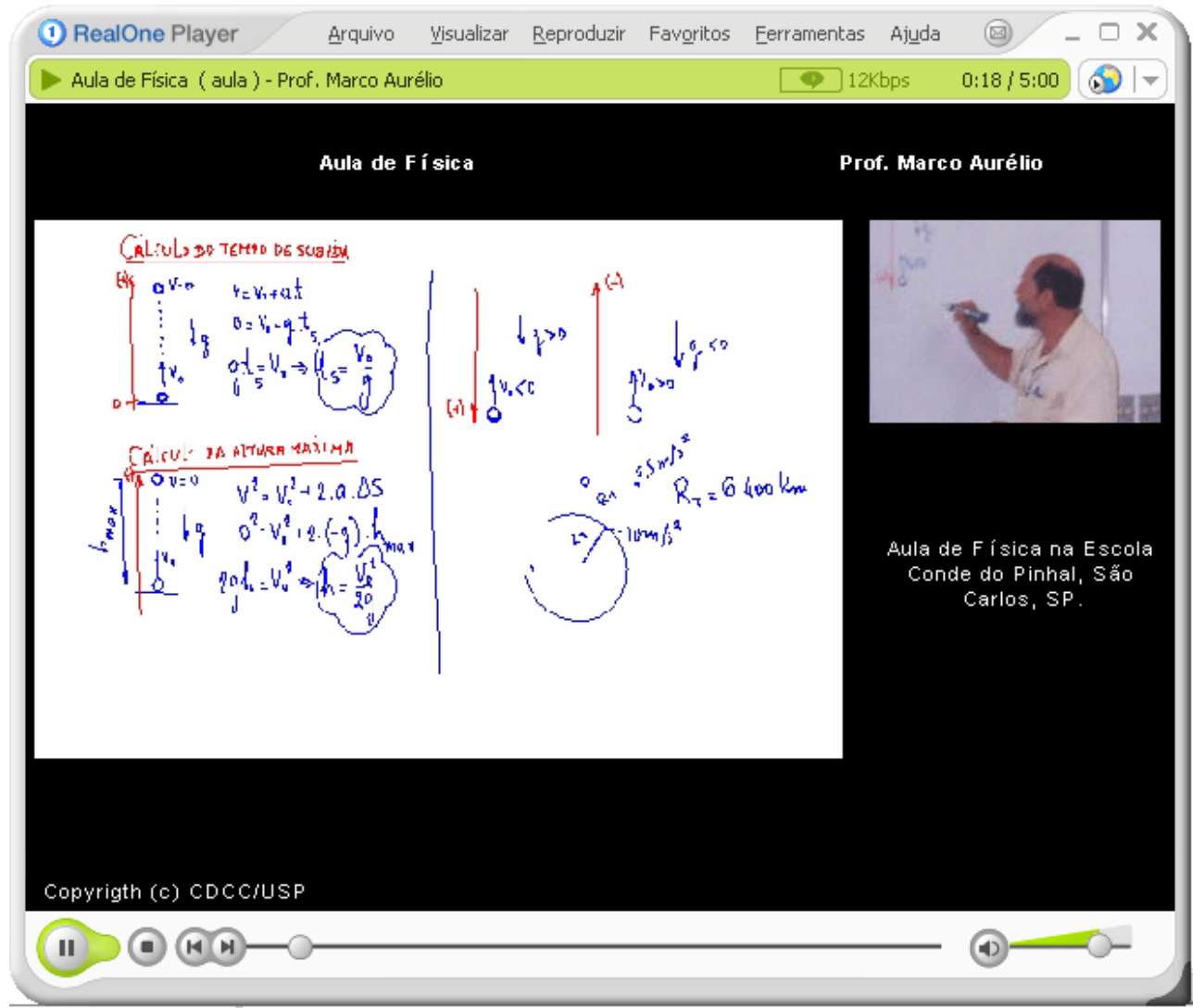

Material educacional multimídia elaborado com o InMid. 


\section{Anexo D}

Exercício aplicado com os futuros professores, em 2003, no Curso de Licenciatura em Ciências Exatas da USP/São Carlos, durante a atividade-reflexão. 


\section{Curso de Licenciatura em Ciências Exatas - USP/São Carlos}

\section{Disciplina: Instrumentação para o Ensino Ano: 2003}

Nome:

E-mail: Idade:

Quais seus conhecimentos em informática:

1) Execute as atividades “a”, “b”, “c”, “d” e responda a questão “e”.

a. Entre na pasta /InMid/tecnologia/boardcast

b. Abra o arquivo boardcast.smi e assista a aula

c. Entre na pasta /InMid/tecnologia/boardcast2

d. Abra o arquivo boardcast2.smi, assista a aula e responda a questão seguinte

e. Como aluno, compare as tecnologias existentes nas aulas, especificamente foto do professor e vídeo da aula.

2) Execute as atividades "a” e "b" e responda a questão “c”.

a. Entre na pasta /InMid/tecnologia/aula1

b. Abra o arquivo aula1.smi e assista a aula

c. Como aluno, compare essa aula, onde foram utilizados slides, com as aulas anteriores, onde foram utilizadas informações dinâmicas capturadas com o mimio.

3) Execute as atividades “a”, "b”, “c”, “d” e “f” e responda as questões “e” e “g”.

a. Entre na pasta /InMid/tecnologia/aula4

b. Abra o arquivo aula4.smi e assista a aula

c. Entre na pasta /InMid/tecnologia/caption

d. Abra o arquivo caption.smi, assista a aula e responda à questão seguinte:

e. Existe algum benefício, para a aprendizagem, na utilização de texto dinâmico, como o da aula "caption"? Comente.

f. Abra o arquivo aula4.html e responda à questão seguinte:

g. Na sua opinião, qual a melhor interface: a visualizada na aula4.smi ou a visualizada na aula4.html? Comente. 


\section{Anexo E}

Questionários aplicados, com os futuros professores, nos anos de 2002 e 2003, no Curso de Licenciatura em Ciências Exatas da USP/São Carlos. 
Curso de Licenciatura em Ciências Exatas - USP/São Carlos

Disciplina: Instrumentação para o Ensino Ano: 2002

Avaliação das tecnologias pelos alunos/professores

Nome:

Data:

E-mail: Cidade/Estado:

1) Como você classificaria a tecnologia MIMIO quanto à:

\section{Facilidade de uso do software}

$\square_{\text {Muito Boa }} \boldsymbol{C}_{\text {Boa }} \boldsymbol{C}_{\text {Média }} \boldsymbol{C}_{\text {Fraca }} \boldsymbol{C}_{\text {Muito Fraca }}$

Facilidade de uso do equipamento

$\mathbb{C}_{\text {Muito Boa }} \boldsymbol{C}_{\text {Boa }} \quad \boldsymbol{C}_{\text {Média }} \boldsymbol{C}_{\text {Fraca }} \boldsymbol{C}_{\text {Muito Fraca }}$

2) Como professor, quais foram suas dificuldades com o uso do MIMIO?

3) Qual a sua opinião sobre as seguintes tecnologias utilizadas na sala de aula durante o curso:

Vídeo -

MIMIO -

Fotos -

Páginas Internet -

4) Como aluno, você acha que a tecnologia MIMIO contribuiu na aprendizagem? Por quê?

5) Como professor, você acha que a tecnologia MIMIO contribuiu para o ensino? Por quê?

6) O que você mais gostou na utilização da tecnologia MIMIO?

7) O que poderia ser melhorado?

8) Você acha que o conjunto das tecnologias MIMIO, vídeo, áudio, fotos e páginas Internet poderá facilitar o ensino/aprendizagem? Explique. 


\section{Curso de Licenciatura em Ciências Exatas - USP/São Carlos \\ Disciplina: Instrumentação para o Ensino - Nov. 2003}

Nome:

1) Sobre as fases da Metodologia de Incorporação de Tecnologias em sala de aula:

Fase 1: PREPARAÇÃO - conhecimento das tecnologias para utilizar em sala de aula, seleção das tecnologias, planejamento do conteúdo e transformação em formas compreensíveis aos alunos

Fase 2: PRODUÇÃO - captura da informação e edição das mídias

Fase 3: INTEGRAÇÃO - integração das mídias com o InMid

Fase 4: DISTRIBUIÇÃO - gravação em CD e/ou distribuição pela Internet

a) A definição destas fases auxiliou você na incorporação de tecnologias em sua aula? Comente.

b) Em qual fase você encontrou maiores dificuldades? Comente.

2) Quais tecnologias você utilizou em sua aula?

3) O que você mais gostou na utilização das tecnologias em sala de aula?

4) Com relação à Fase 3, de Integração das mídias com o InMid, responda:

a) Você achou o InMid fácil e simples de usar?

b) Como você classifica a facilidade de uso do InMid
C Muito Boa
B Boa
C Média
C Fraca
C Muito Fraca

c) Como você classifica o visual (layout) do InMid
C Muito Bom
C Bom
C Médio
E Fraco
C Muito Fraco

d) O que você mais gostou no InMid? Há algum ponto que poderia ser melhorado?

e) Você acha que o produto gerado na integração das mídias pode contribuir para o ensino/aprendizagem? Comente. 


\section{Referências Bibliográficas}

ABDAL-HAQQ, I. Infusing technology into preservice teacher education. ERIC Clearinghouse on Teaching and Teacher Education, Washington DC., 1995. ED389699.

ABOWD, G. D.; ATKESON, C. G.; FEINSTEIN, A.; HMELO, C.; KOOPER, R.; LONG, S.; SAWHNEY, N.; TANI, M. Teaching and learning as multimedia authoring: the Classroom 2000 project. In: Proceedings of the ACM Multimedia '96 Conference, p.187-198, November 1996.

ABOWD, G. D. Classroom 2000: inventing a future for education. In: Workshop on Human-Centered Systems, Washington, D.C., November 14, 1997.

ABOWD, G. D. Classroom 2000: an experiment with the instrumentation of a living educational environment. IBM Systems Journal, Special issue on Pervasive Computing, v.38, n.4, p. 508-530, October 1999.

ABRANCHES, S. P. Modernidade e formação de professores: a prática dos multiplicadores dos Núcleos de Tecnologia Educacional do Nordeste e a informática na educação. São Paulo, 2003, 278p. Tese (Doutorado), Faculdade de Educação, Universidade de São Paulo.

ALBION, P. R.; GIBSON, I. W. Problem-based learning as a multimedia design framework in teacher education. Journal of Technology and Teacher Education, v. 8, n.4, p. 315, Winter 2000.

ALMEIDA, R. M. As dificuldades de aprendizagem: repensando o olhar e a prática no cotidiano da sala de aula. Florianópolis, 2002. 130p. Dissertação (Mestrado) Engenharia de Produção e Sistemas, Universidade Federal de Santa Catarina.

ANDRÉ, M. A. A pesquisa sobre formação de professores no Brasil - 1990 - 1998. In: CANDAU, V. M., org. Ensinar e aprender: sujeitos, saberes e pesquisa. Rio de Janeiro, DP\&A, 2000. p. 83-100.

ANTONELLO, S. L. Software para construção de tabelas interativas para Educação à Distância. São Carlos, 2003. 128p. Dissertação (Mestrado) - Instituto de Física de São Carlos, Universidade de São Paulo.

ASENSIO, M.; STROM, J.; YOUNG, C. Click and Go Video. In: Proceedings of the Educational Innovation in Economics and Business Administration Conference, 8., Nice, June 2001. 
ASENSIO, M.; YOUNG, C. A learning and teaching perspective. In: THORNHILL, S.; ASENSIO, M.; YOUNG, C., ed. Video streaming: a guide for educational development. The JISC Click and Go Video Project, Manchester, 2002. p.10-19. Disponível em: <http://www.clickandgovideo.ac.uk>. Acesso em: 2003.

AZEVEDO, W. Muito além do jardim da infância: o desafio do preparo de alunos e professores on-line. In: Congresso Internacional de Educação à Distância, 6., Rio de Janeiro, 1999. Disponível em:

<http://www.abed.org.br/publique/cgi/cgilua.exe/sys/start.htm?UserActiveTemplate =4abed\&infoid=141\&sid=114>. Acesso em: 19/06/2001.

BARBETA, V. B.; YAMAMOTO, I. Desenvolvimento e utilização de um programa de análise de imagens para o estudo de tópicos de mecânica clássica. Revista Brasileira de Ensino de Física, v. 24, n. 2, p. 158-167, 2002.

BARROS, F. F. M. Capacitação de professores para utilização de novas tecnologias. Florianópolis, 2002. Dissertação (Mestrado) - Engenharia de Produção, Universidade Federal de Santa Catarina.

BECK, R.J. Learning objects: what? Center for International Education. University of Winsconsin, Milwaukee, 2001.

BERNERS-LEE, T.; CAILLIAU, R.; LUOTONEN, A.; NIELSEN, H. F.; SECRET, A. The World-Wide Web. Communications of the ACM, v.37, n.8, p.76-82, August 1994.

BITNER, N.; BITNER, J. Integrating technology into the classroom: eight keys to success. Journal of Technology and Teacher Education, v. 10, n. 1, p. 95-100, Spring, 2002.

BRAND, G. A. What research says: training teachers for using technology. Journal of Staff Development, v. 19, n. 1, Winter 1997.

BROTHERTON, J. A. enriching everyday activities through the automated capture and access of live experiences. eClass: building, observing and understanding the impact of capture and access in an educational domain. Georgia, 2001. 186p. Tese (Doutorado) - Georgia Institute of Technology.

BYROM, E. Review of the professional literature on the integration of technology into educational programs. SEIR*TEC SouthEast Initiatives Regional Technology in Education Consortium. 1997. Disponível em: <http://www.seirtec.org/publications/litreview.html>. Acesso em: 02/2004.

CALDERHEAD, J. Teachers: beliefs and knowledge structures and comprehension processes. In: CALDERHEAD, J.; CALFEE, R. C., eds. Exploring teachers' thinking. New York, Macmillan, 1996. p. 709-725.

CALIGIORNE, D. O. Informação na educação: um estudo sobre a inserção e utilização das novas tecnologias na formação dos professores de graduação em uma 
faculdade brasileira. Florianópolis, 2002. 93p. Dissertação (Mestrado) - Engenharia de Produção, Universidade Federal de Santa Catarina.

CATTELAN, R. G., ANDRADE, A. R., ROCHA, C. F. P.; PIMENTEL, M. G. C. iClass: um sistema para captura e acesso de sessões em ambiente educacional. Revista Eletrônica de Iniciação Científica, Sociedade Brasileira de Computação, Março 2003.

CHUDZIKIEWICZ, I. S. A utilização da tecnologia nos cursos de graduação da UNIANDRADE, campus Muricy e suas contribuições para o processo ensino aprendizagem. Florianópolis, 2000. 159p. Dissertação (Mestrado) - Engenharia de Produção, Universidade Federal de Santa Catarina.

CLANDININ, D. J.; CONNELLY, F. M. Teacher's professional knowledge landscapes: teacher-stories - stories of teachers - school stories - stories of schools. Educational Researcher, v. 25, n. 3, p. 24-30, 1996.

CLANDININ, D. J.; CONNELLY, F. M. Narrative inquiry: experience and story in qualitative research. San Francisco, Jossey-Bass, publishers, 2000.

COSCARELLI, C. Objetos para aprender fazendo. Disponível em: $<$ http://www.universiabrasil.net/ead/materia.jsp?id=3025>. Acesso em: 10/03/2004.

CORDEIRO, A. P. A informática como instrumento de desenvolvimento da qualidade do processo ensino-aprendizagem. Florianópolis, 2000. 81p. Dissertação (Mestrado) - Engenharia de Produção, Universidade Federal de Santa Catarina.

CYSNEIROS, P. G. A gestão de novas tecnologias na escola pública. In: Congresso Iberoamericano de Informática Educativa, 5., Chile, Dezembro 2000.

DANTAS, A. S. A formação do professor para o uso das tecnologias de comunicação e informação: a realidade da universidade do Estado do Rio Grande do Norte. Florianópolis, 2001. Dissertação (Mestrado) - Engenharia de Produção, Universidade Federal de Santa Catarina.

DELL'AGLIO, D.; KISSMANN, D. B.; CHARCZUK, S. B. Um paradigma emergente na educação superior: percepções de professores quanto às novas tecnologias.Colabor@ (Revista Digital da CVA-RICESU - Comunidade Virtual de Aprendizagem da Rede das Instituições Católicas de Ensino Superior), v.1, n. 3, 12 p., fevereiro 2002.

DEMO, P. Desafios Modernos da Educação. Petrópolis, RJ, Vozes, 1993.

DESCROVI, E. G. Perspectivas do uso pedagógico da informática nas escolas públicas da área de abrangência do núcleo de tecnologia educacional de Foz do Iguaçu/PR. Florianópolis, 2002. 71p. Dissertação (Mestrado) - Engenharia de Produção, Universidade Federal de Santa Catarina. 
DINIZ, S. N. F. O uso das novas tecnologias em sala de aula. Florianópolis, 2001. Dissertação (Mestrado) - Engenharia de Produção, Universidade Federal de Santa Catarina.

DOWNES, S. Learning objects: resources for distance education worldwide. In: International Review of Research in Open and Distance Learning, v. 2, n. 1, 2001.

EGBERT, J.; PAULUS, T. M.; NAKAMICHI, Y. The impact of CALL instruction on classroom computer use: a foundation for rethinking technology in teacher education. Language Learning \& Technology, v. 6, n. 3, p. 108-126, September 2002.

ELBAZ, F. Teacher thinking: a study of practical knowledge. New York, Nichols, 1983.

FERREIRA, J. M. M. Novas tecnologias para uma nova prática pedagógica (a formação de professores no curso de letras da faculdade de filosofia, ciências $e$ letras do UNIS-Varginha). Florianópolis, 2001. Dissertação (Mestrado) - Engenharia de Produção, Universidade Federal de Santa Catarina.

FULLAN, M.G. The meaning of educational change. New York, Teachers College Press, 1982.

GALLOWAY, J. P. How teachers use and learn to use computers. In: Proceedings of the Society for Information Technology and Teacher Education International Conference, 1997.

GALLOWAY, J. P. Technology education and integration: a position paper on attitude, perspective and commitment. In: Proceedings of the Society for Information Technology and Teacher Education International Conference, v.2001, n.1, p. 415416, 2001.

GARCÍA, C. M. A formação de professores: Novas perspectivas baseadas na investigação sobre o pensamento do professor. In: NÓVOA, A., coord. Os professores e a sua formação. 2. ed. Lisboa, Dom Quixote, 1995. p.51-76.

GARCÍA, C. M. Formação de professores - para uma mudança educativa. Porto, Editora Porto, 1999.

GUERRINI, I. M.; CASTRO, A. C. SAM - Uso do computador na Mecânica. São Carlos, CDCC/USP, 2003. Disponível em:

$<$ http://www.educar.sc.usp.br/experimentoteca>. Acesso em: 12/2003.

HADLEY, M.; SHEINGOLD, K. Commonalities and distinctive patterns in teachers' integration of computers. American Journal of Education, v. 101, p. 261-315, May 1993.

HANDA, J. K.; SILVA, J. B. G. Objetos de Aprendizagem (Learning Objects). Boletim EAD. Centro de Computação, Unicamp. 31 Jan. 2003. 
HAKKARAINEN, K.; MUUKONEN, H.; LIPPONEN, L.; ILOMAKI, L.; RAHIKAINEN, M.; LEHTINEN, E. Teachers' Information and Communication Technology (ICT) skills and practices of using ICT. Journal of Technology and Teacher Education, v. 9, n. 2, p. 181-197, Summer 2001.

IMBERNÓN, F. Formação docente e profissional: formar-se para a mudança e a incerteza. São Paulo, Cortez, 2000.

INSTRUMENTAÇÃO para o Ensino. Disciplina do curso de Licenciatura em Ciências Exatas da Universidade de São Paulo. São Carlos, USP. Disponível em:

$<$ http://sistemas.usp.br/jupiterweb/jupDiscip?sgldis=SLC0596\&verdis=1>. Acesso em: 12/2002.

JONASSEN, D. H. Thinking technology: towards a constructivist design model. Educational Technology, v.34, n.4, p.34-37, 1994.

JONES, A. J. Integration of ICT in an Initial Teacher Training Course: Participants' Views. In: Proceedings of the World Conference on Computers in Education, 7., Australian Topics, v. 8, Jul. 2002.

KENSKI, V. M. Tecnologias e ensino presencial e à distância. Campinas, Papirus, 2003.

KLAUMANN, I. A formação de professores e sua competência para uma educação básica de qualidade: uma proposta de curso à distância. Florianópolis, 2002. Dissertação (Mestrado) - Engenharia de Produção, Universidade Federal de Santa Catarina.

KNOWLES, J. G.; COLE, A. L.; PRESSWOOD, C. S. Through preservice teachers' eyes: experiences through narrative and inquiry. New York, McMillan College Publishing Co., 1994.

KUECHLER, M. Multimedia contents for course web pages: Preliminary Explorations. February 2000. Disponível em:

<http://maxweber.hunter.cuny.edu/ mkuechle/stream-test.htm>. Acesso em: 2003.

LANDIM, C. M. M. P. F. Educação à distância: algumas considerações. Rio de Janeiro, 1997.

LATCHMAN, H., A.; KIM, J.; TINGLING, D. BS and MS online degrees using a lectures on demand approach. In: Proceedings of the International Conference on Engineering Education, Ostrava, Prague, Czech Republic, August 10-14 1999.

LATCHMAN, H. A.; SUHARITDAMRONG, W.; JI, B. "Online Virtual Classes: Better Than Being There?”. In: Proceedings of the IEEE ITHET, Budapest, Hungary, p. 250-255, August 2002.

LAURILLARD, D. Multimedia and the changing experience of the learner. British Journal of Educational Technology, v. 26, n. 3, 1995. 
LEITE, L. S., org. Tecnologia educacional: descubra suas possibilidades na sala de aula. Rio de Janeiro, Editora Diadorim, 1996.

LESSIE, D. Video capture and analysis. Journal of College Science Teaching, v. 30, n. 4, 2001.

LICENCIATURA em Ciências Exatas. Curso da Universidade de São Carlos, campus de São Carlos. São Carlos, USP. Disponível em:

< http://www.if.sc.usp.br/grad/cursos_lic.php>. Acesso em: 01/2002.

LIMA, E. F. Começando a ensinar: começando a aprender? São Carlos, 1996. Tese (Doutorado) - Centro de Ciências Humanas, Universidade Federal de São Carlos.

LIMA, P. R. T. Novas tecnologias da informação e comunicação na educação e a formação dos professores nos cursos de Licenciatura do Estado de Santa Catarina. Florianópolis. Florianópolis, 2001. 85 p. Dissertação (Mestrado) - Ciência da Computação, Universidade Federal de Santa Catarina.

MAGALHÃES, M. G. M. Estudo e avaliação de Educação à Distância utilizando a tecnologia WWW. São Carlos, 1997. 154p. Dissertação (Mestrado) - Instituto de Física de São Carlos, Universidade de São Paulo.

MAGALHÃES, M. G. M.; SCHIEL, D. A method for evaluation of a course delivered via the World Wide Web in Brazil. In: MOORE, M. G.; COZINE, G. T., eds. Web-Based Communications, the Internet, and Distance Education. The Pennsylvania State University, 2000. p. 137-141.

MAGALHÃES, M. G. M.,; SCHIEL, D. Estudos e proposta de integração de tecnologias e de sincronização de mídias para fins educacionais. In: Workshop da pós-graduação do IFSC/USP, 7., Instituto de Física de São Carlos, Universidade de São Paulo, São Carlos, Brasil, 2003.

MAGALHÃES, M. G. M.; SCHIEL, D. Technology integration and production of educational multimedia material by the pre-service teacher. In: Proceedings of the World Conference on Educational Multimedia, Hypermedia and Telecommunications, v.2004, n.1, p. 3129-3133, 2004.

MAGALHÃES, M. G. M.; SCHIEL, D.; GUERRINI, I.M.; MAREGA JR, E. Utilizando tecnologia computacional na análise quantitativa de movimentos: uma atividade para alunos do Ensino Médio. Revista Brasileira de Ensino de Física, v. 24, n. 2, p. 97-102, 2002.

MARCELO, C. Pesquisa sobre a formação de professores: o conhecimento sobre o aprender e ensinar. Revista Brasileira de Educação, v.9, p. 51-75, 1998.

MCBRIDE, R., ed. The In-Service Training of Teachers. London, Falmer Press, 1989.

MEC produz material multimídia. Folha de São Paulo, São Paulo, 12 mar. 2004. Educação. 
MELO, E. M. D. V. Com as novas tecnologias e as competências do professor, preparar os alunos para as exigências do mundo. Florianópolis, 2001. Dissertação (Mestrado) - Engenharia de Produção, Universidade Federal de Santa Catarina.

MENDES, R. A. V. Avaliação de um curso de educação a distância para formação continuada de professores em Matemática. Bauru, 2003. 152p. Dissertação (Mestrado) - Faculdade de Ciências, Universidade Estadual Paulista.

MENDONÇA, M. A. B. M. Novas tecnologias educacionais: uma cultura emergente na formação docente. Araraquara, 2003. 195p. Dissertação (Mestrado) - Faculdade de Ciências e Letras, Universidade Estadual Paulista.

MINATEL, E.; SCHIEL, D. Manual do SAM. São Carlos, São Paulo, CDCC/USP, 1999.

MIZUKAMI, M. G. N.; REALI, A. M. M. R.; REYES, C. R.; MARTUCCI, E. M.; LIMA, E. F.; TANCREDI, R. M. S. P.; MELLO, R. R. Escola e aprendizagem da docência: processos de investigação e formação. São Carlos, EdUFSCar, 2002.

MORAN, J. M. Novas tecnologias e o reencantamento do mundo. Tecnologia Educacional, v. 23, n.126, p.24-26, 1995.

MORAN, J. M.; MASETTO, M.; BEHRENS, M. Novas tecnologias e mediação pedagógica. São Paulo, Papirus Editora, 2000.

MORAN, J. M. Desafios da televisão e do vídeo à escola. Disponível em: $<$ http://www.eca.usp.br/prof/moran/desafio.htm>. Acesso em: 2003.

MUIR-HERZIG, R. G. Technology and its impact in the classroom. Computers \& Education, v. 42, p. 111-131, 2004.

NEVADO, R. A. Espaços interativos de construção de possíveis: uma nova modalidade de formação de professores. Porto Alegre, 2001. Tese (Doutorado) Informática na Educação, Universidade Federal do Rio Grande do Sul.

NISAN-NELSON, P. D. Technology integration: a case of professional development. Journal of Technology and Teacher Education, v.9, n.1, p. 83-103, 2001.

NÓVOA, A. Formação de professores e profissão docente. In: NÓVOA, A., coord. Os professores e a sua formação. 2. ed. Lisboa, Dom Quixote, 1995. p. 15-34.

OFFICE OF TECHNOLOGY ASSESSMENT. Teachers and technology: making the connection (OTA-CHR-616). Washington DC, U.S. Government Printing Office, April 1995.

ORTH, A. I. Capacitação de docentes para o ensino e uso da informática: uma questão inadiável. Scientia, v. 7, n. 2, p. 23-33, 1996. 
PEARSON, J. Electronic networking in initial teacher education: is a virtual faculty of education possible? Computers \& Education, v. 32, p. 221-238, 1999.

PÉREZ GÓMEZ, A. O pensamento prático do professor: a formação do professor como prático reflexivo. In: NÓVOA, A., coord. Os professores e a sua formação. 2.ed. Lisboa, Dom Quixote, 1995. p. 93-114.

PERRENOUD, P. Práticas pedagógicas, profissão docente e formação. Perspectivas sociológicas. 2. ed. Lisboa, Dom Quixote, 1997.

PERRENOUD, P. Dez novas competências para ensinar. Porto Alegre, Artes Médicas, 2000.

PIMENTEL, M. G.; ABOWD, G. D; ISHIGURO, Y. Linking by interacting: a paradigm for authoring hypertext. In: Proceedings of the ACM Conference on Hypertext Hypermedia, 11., May 2000. p. 39-48.

PIMENTEL, M. G.; ISHIGURO, Y; ABOWD, G. D.; KERIMBAEV, B.; GUZDIAL, M. Supporting educational activities through dynamic Web interfaces. Interacting with Computers, v. 13, n. 3, p. 353-374, February 2001.

POPE, M.; HARE, D.; HOWARD, E. Technology integration: closing the gap between what preservice teachers are taught to do and what they can do. Journal of Technology and Teacher Education, v. 10, n. 2, p. 191-203, Summer 2002.

PREECE, J.; ROGERS, Y.; SHARP, H.; BENYON, D.; HOLLAND, S.; CAREY, T. Human-computer interaction. Wokingham, England, Addison-Wesley, 1994. p.601639.

QUARTIERO, E. M.; CATAPAN, A. H. A rede eletrônica e a formação de professores: documento hipermídia. In: Simposio Internacional de Computación en Educación, 16., Monterrey, México, 2000.

QUARTIERO, E. M. As tecnologias de informação e de comunicação no espaço escolar: o Programa Nacional de Informática na Educação (ProInfo) em Santa Catarina. Florianópolis, 2002, 255p. Tese (Doutorado) - Engenharia de Produção, Universidade Federal de Santa Catarina.

RAMALHO, B. L.; NÚÑEZ, I. B.; TERRAZZAN, E.; PRADA, L. E. A. A Pesquisa sobre a formação de professores nos programas de Pós-Graduação em Educação: o caso do ano 2000. In: Reunião Anual da ANPEd, 25., Caxambu, 2002.

REED., R. Streaming technology improves students achievement. T.H.E. Journal, v. 30, n. 7, February 2003.

RIBAS, L. A. M. O professor do século XXI: desafios e perspectivas atuais da escola pública do Paraná. Florianópolis, 2002. 74p. Dissertação (Mestrado) Engenharia de Produção, Universidade Federal de Santa Catarina. 
RIEBER, L.; WELLIVER, P. Infusing educational technology into mainstream educational computing. International Journal of Instructional Media, n.1 v. 1, p. 2132, 1989.

ROCHA, C. A. Elos entre a formação para o ensino de Física e as novas tecnologias. Florianópolis, 2001, 152p. Dissertação (Mestrado) - Engenharia de Produção, Universidade Federal de Santa Catarina.

ROMISZOWSKI, A. J.; MASON, R. Computer-Mediated Communication. In: JONASSEN, D. H., ed. Handbook of research for educational communications and technology: a project of the Association for Educational Communications and Technology. New York, Simon \& Schuster Macmillan, 1996. p. 438-456.

ROSCHELLE, J.; PEA, R.; HOADLEY, C.; GORDIN, D.; MEANS, B. Changing how and what children learn in school with computer-based technologies. The Future of Children, Children and Computer Technology, v. 10, n. 2, p.76-101, 2000.

SANDHOLTZ, J. H. Learning to teach with technology: a comparison of teacher development programs. Journal of Technology and Teacher Education, v. 9, n. 3, p. 349-374, Autumn 2001.

SANTOS, D. S. A formação do professor na era das inovações tecnológicas: o caso do curso superior de formação de professores para as quatro primeiras séries do Ensino Fundamental. Florianópolis, 2002. Dissertação (Mestrado) - Engenharia de Produção, Universidade Federal de Santa Catarina.

SCHECHTMAN, S. Interatividade entre orientador e aprendiz em um curso virtual: prática ou teoria? Rio de Janeiro, 2001. Monografia (Curso de Pós-Graduação Lato Sensu em Educação a Distância) - Universidade Católica de Brasília.

SCHERRER, R. SMIL - Linguagem de sincronização. Boletim EAD. Centro de Computação, Unicamp. 31 Ago. 2001.

SCHIEL, D; DASSIN, J.; MAGALHÃES, M. G. M.; GUERRINI, I. M. Evaluation of Web-based instruction: a case study in Brazilian high schools. In: Proceedings of the International Conference on Mathematics/Science Education \& Technology, v. 2000, n. 1, p. 350-355, San Diego, February 2000.

SCHIEL, D; DASSIN, J.; MAGALHÃES, M. G. M.; GUERRINI, I. M. High schools Physics instruction by Way of the World Wide Web: a Brazilian case study. Journal of Interactive Learning Research, v. 13, n. 4, p. 293-309, 2002a.

SCHIEL, D.; GUERRINI, I. M.; MAGALHÃES, M.G.M.; MAREGA JR., E. O Uso da informática na análise quantitativa de movimentos: uma atividade para alunos do Ensino Médio. In: Encontro de Pesquisa em Ensino de Física - EPEF, 8., Águas de Lindóia - SP, junho 2002b.

SCHIEL, D.; GUERRINI, I. M.; CASTRO, A. C.; MAGALHÃES, M. G. M. Digital motion analysis of ball games. In: International Conference on Science and Mathematics Education, Rio de Janeiro, September 2002c. 
SCHÖN, D. The reflective practitioner. New York, Basic Books, 1983.

SCHÖN, D. Educating the reflective practitioner. San Francisco, Jossey-Bass, 1987.

SCHÖN, D. Coaching reflective teaching. In: GRIMMETT, P. P.; ERICKSON, G. L. eds. Reflection in teacher education. New York, Teachers College Press, 1988. p. 19-30.

SCHÖN, D. A. Formar professores como profissionais reflexivos. In: NÓVOA, A., coord. Os professores e a sua formação. 2. ed. Lisboa, Dom Quixote, 1995. p. 77-92.

SHARPE, L.; HU, C.; CRAWFORD, L.; GOPINATHAN, S.; KHINE, M. S.; MOO, S. N.; WONG, A. Enhancing multipoint desktop video conferencing (MDVC) with lesson video clips: recent developments in pre-service teaching practice in Singapore. Teaching and Teacher Education. v. 19, p. 529-541, 2003.

SHEPHARD, K. Streaming audio and video for course design. LTSN Generic Centre and ALT Association for Learning Technology. October 2002. Disponível em: <http://www.ltsn.ac.uk/genericcentre/index.asp?id=17117>. Acesso em: 2003.

SHERWOOD, C. Australian experiences with the effective classroom integration of information technology: implications for teacher education. Journal of Information Technology for Teacher Education, v. 2, n. 2, p. 167-179, 1993.

SHULMAN, L. S. Those who understand: knowledge growth in teaching. Educational Researcher, v. 15, n.2, p. 4-14, February 1986.

SHULMAN, L. S. Knowledge and teaching: foundations of the new reform. Harvard Educational Review, v. 57, n. 1, p. 1-22, February. 1987.

SILVA, C. M. C. Novas tecnologias na educação - o professor como mediador no processo educativo. Florianópolis, 2000. Dissertação (Mestrado) - Engenharia de Produção, Universidade Federal de Santa Catarina.

SILVA, V. S. P. Informática na educação - repensando o uso do computador nas escolas de Educação Infantil e Ensino Fundamental. Florianópolis, 2000. Dissertação (Mestrado) - Engenharia de Produção, Universidade Federal de Santa Catarina.

SILVEIRA, C. A. S. Concepções do papel do professor frente às novas tecnologias um estudo de caso na Escola Estadual Prof. Plínio Ribeiro - Montes Claros/MG. Florianópolis, 2002. Dissertação (Mestrado) - Engenharia de Produção, Universidade Federal de Santa Catarina.

SIMIÃO, L. F. Aprendizagem profissional da docência: uma experiência utilizando o computador em curso de formação inicial. São Carlos, 2001. Dissertação (Mestrado) - Centro de Ciências Humanas. Universidade Federal de São Carlos. 
SIMIÃO, L. F.; REALI, A. M. M. R. O uso do computador, conhecimento para o ensino e a aprendizagem profissional da docência. In: MIZUKAMI, M. G. N.; REALI, A. M. M. R. Formação de professores, práticas pedagógicas e escola. São Carlos, EdUFSCar, 2002. p. 125-149.

SOSTERIC, N.; HESEMEIER, S. When is a learning object not an object: a first step towards a theory of learning objects. In: International Review of Research in Open and Distance Learning, v.3, n.2, October 2002.

SOUZA, J. A A aplicação das novas tecnologias no processo de ensinoaprendizagem nas Escolas Públicas Estaduais da Grande Florianópolis. Florianópolis, 2000. Dissertação (Mestrado) - Engenharia de Produção, Universidade Federal de Santa Catarina.

STROM, J. Streaming video: overcoming barriers for teaching and learning. In: Proceedings of the International Symposium on Educational Conferencing, 1., Banff, Alberta, Canada, 2002.

SWAN K.; HOLMES, A.; VARGAS, J. D.; JENNINGS, S.; MEIER, E.; RUBENFELD, L. Situated professional development and technology integration: The Capital Area Technology and Inquiry in Education (CATIE) mentoring program. Journal of Technology and Teacher Education, v.10, n.2, p. 169-190, Summer 2002.

TELLES, M. Learning objects e outros. DynamicLab Gazette, 15 mar. 2004. Disponível em:

$<$ http://www.dynamiclab.com/mod/forum/discuss.php?d=464>. Acesso em: $15 / 04 / 2004$.

TORRES, R. M. Nuevo rol docente: qué modelo de formación, para qué modelo educativo? In: FUNDACIÓN SANTILLANA. Aprender para el futuro. Nuevo marco de la tarea docente. Documentos en Debate. Madrid, 1999. p. 99-112.

VERMELHO, C.; BRITO, G. S.; PURIFICAÇÃO, I. Capacitação de professores para uso da tecnologia da informação no ambiente escolar da rede pública. In: Congresso da Rede Iberoamericana de Informática Educativa, 4., Brasília, Outubro 1998.

WILEY, D. A. Learning object and sequencing theory. Provo, 2000. 131p. Tese (Doutorado) - Department of Instructional Psychology and Technology, Brigham Young University.

WILSON, S. M.; SHULMAN, L. S.; RICHERT, A. E. “150 different ways” of knowing: representation of knowledge in teaching. In: CALDERHEAD, J., ed.. Exploring teachers' thinking. London, Cassell, 1987. p. 104-124.

WEISER, M. Some computer science issues in ubiquitous computing. Communications of the ACM, v.7, n.36, p.74-83, July 1993. 
WHITE, P.; THORNHILL, S.; YOUNG, C. Presenting your content. In: THORNHILL, S.; ASENSIO, M.; YOUNG, C., eds. Video streaming: a guide for educational development. The JISC Click and Go Video Project, Machester, 2002. p.58-63. Disponível em: <http://www.clickandgovideo.ac.uk>. Acesso em: 2003. 


\section{Bibliografia Consultada}

ALMEIDA, M. G. M. Formação de professores na modalidade de educação à distância: análise inicial de um percurso. In: Congresso Internacional de Educação à Distância, 7., São Paulo, 13-18 agosto 2000.

BLAKOWSKI, G.; STEINMETZ, R. A Media Synchronization Survey: Reference Model, Specification, and Case Studies. IEEE Journal on Selected Areas in Communications, v. 14, n. 1, p. 5-35, January 1996.

BOF, A. M.; SALGADO, M. U. C.; MOORE, M. G.; MENEZES, M. B.; RAMOS, W. M. O Proformação: proposta pedagógica, estrutura e implementação. In: Congresso Internacional de Educação à Distância, 7., São Paulo, 13-18 agosto 2000.

BOWERS, J.; DOERR, H. Designing multimedia case studies for prospective mathematics teachers. Journal of Educational Multimedia and Hypermedia. v. 12, n. 2, p. 135-161, 2003.

BROWN, S. Streaming Media in UK Higher and Further Education. TechLearn service of the JISC funded Technologies Centre. 16 January 2003. Disponível em: <http://www.techlearn.ac.uk/NewDocs/Streaming200103.doc>. Acesso em: 2003.

CLIFT, R. T.; THOMAS, L.; LEVIN, J.; LARSON, A. Technologies in contexts: implications for teacher education. Teaching and Teacher Education, v. 17, p. 33-50, 2001.

DIEM, R. A. Preparing teachers to use and apply technology: new models for a new era. Journal of Universal Computer Science, v. 2, n. 10, p. 711-716, 1996.

EAGLE Consulting Services. Streaming Video on the Internet. Disponível em: $<$ http://hyperdisc.unitec.ac.nz/ia00s1/iagrp3/Streaming-Video2.htm>. Acesso em: 2003.

IN TIME. Integrating New Technologies Into the Methods of Education. Disponível em: <http://www.intime.uni.edu/model/technology/comps.html>. Acesso em: 2003.

JOHNSON, D. W.; JOHNSON, R. T. Cooperation and the use of technology. In: JONASSEN, D. H., ed. Handbook of research for educational communications and technology. New York, Simon \& Schuster Macmillan, 1996. p. 1017-1044.

KERREY B.; ISAKSON, J. The Power of the Internet for Learning: Moving From Promise to Practice. Web-Based Education Commission. Washington, D. C., 
December

2000.

Disponível

em:

<http://www.ed.gov/offices/AC/WBEC/FinalReport/index.html>. Acesso em: 2003.

KOVALIK, C. Reflections on a technology integration project. Journal of Technology and Teacher Education, v.11, n.1, p73-90, Spring 2003.

KULIK J. A.; BANGERT, R. L.; WILLIAMS, G. W. Effects of computer-based teaching on secondary school students. Journal of Educational Psychology, v. 75, n.1, p.19-26, 1983.

LITTLE, T. D. C.; GHAFOOR, A. Synchronization and Storage Models for Multimedia Objects. IEEE Journal on Selected Areas in Communications, v. 8, n. 3, p. 413-427, April 1990.

MEHLENBACHER, B.; MILLER, C. R.; COVINGTON, D.; LARSEN, J. Active and interactive learning online: a comparison of Web-Based and conventional writing classes. IEEE Transactions on Professional Communication, v. 43, n. 2, p. 166-184, June 2000.

NUNES, C. M. F. Saberes docentes e formação de professores: um breve panorama da pesquisa brasileira. Educação \& Sociedade. v. 22, n. 74, p. 27-42, Abril 2001.

NUTTI, J. Z. Professores e especialistas educacionais diante do fracasso escolar: um estudo no cenário das Classes de Aceleração. São Carlos, 2001, 250 p. Tese (Doutorado) - Educação. Universidade Federal de São Carlos.

PRIMO, A. F. T. Ferramentas de interação na Web: travestindo o ensino tradicional ou potencializando a educação através da cooperação. In: Congresso da Rede Iberoamericana de Informática Educativa, 5., Chile, 4-6 Dezembro 2000.

PULLEN, M.; BENSON, M. ClassWise: synchronous Internet desktop education. IEEE Transactions on Education, v. 42, n. 4, November 1999.

REIS, E. M.; REZENDE, F.; BARROS, S. S. Desenvolvimento e avaliação de um ambiente construtivista de aprendizagem a distância para a formação continuada de professores de Física do Norte-Fluminense. In: Congresso Internacional de Educação a Distância, 6., Rio de Janeiro, 25-27 agosto 1999.

RELAN, A.; GILLANI, B. B. Web-based instruction and the traditional classroom: similarities and differences. In: KHAN, B. H., ed. Web-based instruction. Englewood Cliffs, New Jersey, Educational Technology Publications, 1997. p. 4146.

RILEY, R.; HOLLEMAN, F.; ROBERTS, L. E-Learning: Putting a World-Class Education at the Fingertips of All Children. U.S. Education Department's Office of Educational Technology. Washington, D.C., December 1999.

ROBLYER, M. D.; EDWARDS, J.; HAVRILUK, M. A. Integrating educational technology into teaching. Columbus, Ohio, Prentice Hall, 1997. 
ROMISZOWSKI, H. P. Avaliação no design e desenvolvimento de multimídia educativa: estratégia de apoio ou parte do processo? In: Congresso Internacional de Educação a Distância, 7., São Paulo, 13-18 agosto 2000.

SHULMAN, L. S. Taking learning seriously. Change, v. 31, n. 4, p. 10-17, July/August 1999.

SOUZA, T. R. P. A avaliação como prática pedagógica. In: Congresso Internacional de Educação a Distância, 7., São Paulo, 13-18 agosto 2000.

STEFANELLI, E. J. A importância do profissional de comunicação gráfica na produção de material multimídia para EAD. In: Congresso Internacional de Educação a Distância, 7., São Paulo, 13-18 agosto 2000.

STOKES, J. Towards knowledge age teachers: reflective practitioners. In: MCDOUGALL, A.; MURNANE, J. S.; CHAMBERS, D., eds. Computers in education 2001: Australian topics. Sydney, NSW, ACS, 2001. p. 119-124.

SWITZER, T. J.; CALLAHAN, W. P.; QUINN, L. Technology as facilitator of quality education: an unfinished model. In: Congress of Society for Information Technology and Teacher Education, 10., San Antonio, TX., March 1999.

TAMOSAUSKAS, M. R. G. De médico especialista a professor de medicina: a construção dos saberes docentes. São Bernardo do Campo, 2003. 134p. Dissertação (Mestrado) - Faculdade de Educação e Letras, Universidade Metodista de São Paulo.

TILBURY, D. M.; MESSNER, W. C. Control tutorial for software instruction over the World Wide Web. IEEE Transactions on Education, v. 42, n. 4, p. 237-246, November 1999.

VARGO, J. Evaluating the effectiveness of Internet delivered coursework. In: Proceedings of the Australian World Wide Web Conference, 3., Australia, 5-9 July 1997.

VOUK, M. A.; BITZER, D. L.; KLEVANS, R. L. Workflow and end-user quality of service issues in Web-based education. IEEE Transactions on Knowledge and Data Engineering, v. 11, n. 4, p. 673-687, July/August 1999.

WANG, J.; HARTLEY, K. Video technology as a support for teacher education reform. Journal of Technology and Teacher Education, v. 11, n. 1. p. 105-138, 2003.

WATSON, D.; BLAKELEY, B.; ABBOTT, C. Researching the use of communication technologies in teacher education. Computers \& Education, v. 30, n. 1/2, p. 15-21, 1998.

WESTHOFF, G. Building capacity in Wyoming: preparing preservice teachers to integrate technology. In: Society for Information Technology and Teacher Education International Conference, v. 2000, n. 1, p. 1303-1306, 2000. 


\section{Apêndice I}

\section{O Mimio}

O Mimio foi desenvolvido pela empresa Virtual Ink, sediada em Boston, EUA. É composto por uma combinação de hardware portátil e software, o qual possibilita a captura, reprodução e impressão das anotações contidas em uma lousa branca durante uma aula, palestra ou reunião. O Mimio captura instantaneamente essas anotações e as transforma em um arquivo que pode ser compartilhado por várias pessoas. Isto libera os participantes, de uma reunião ou de uma aula, da tarefa de fazer anotações e transcrevê-las. Com a interface do Mimio é possível copiar a informação escrita em tempo real e em cores, sendo compatível com qualquer aplicação padrão do Windows, como editores de texto, planilhas e pacotes gráficos. Os usuários também podem salvar as anotações em outros formatos, como BMP (BitMap Picture), JPG (Joint Photographic Experts Group), HTML.

A integração com projetores multimídia permite que o Mimio exerça outra função: a de um mouse sem fio. Para executar os comandos do mouse é necessário clicar e arrastar a caneta do Mimio diretamente na tela projetada. Esta função também possibilita a alteração simultânea do conteúdo de outros programas.

O Mimio não precisa estar conectado a um computador, pois possui memória interna com capacidade de armazenar as informações escritas na lousa (a princípio, cerca de 10 horas de aula, aproximadamente). Posteriormente, as anotações podem ser salvas no computador, conectando o Mimio por meio de um cabo USB (Universal Serial Bus) (figura 1). 


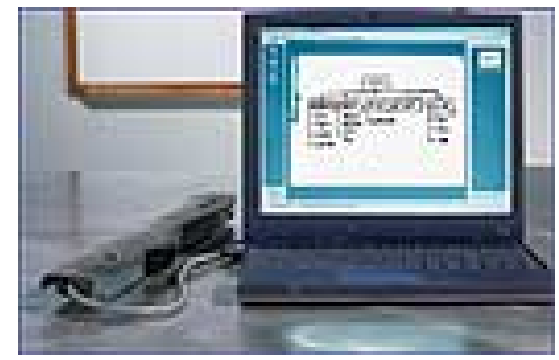

Figura 1 - Mimio Xi, conectado a um computador, para transferir as informações escritas na lousa, durante a aula.

\section{Aspectos Operacionais}

O sistema Mimio é composto por uma barra de captura dobrável e autoaderente, quatro canetas eletrônicas (cápsulas para pilots nas cores preta, vermelha, verde e azul), apagador eletrônico com suporte, CD com software Mimio e MimioMouse e cabo USB. Estes componentes capturam as anotações que o professor escreve na lousa branca, as quais são enviadas automaticamente para o computador, transformando a própria tela em lousa. Qualquer superfície lisa, papel ou até mesmo uma janela ou mesa de vidro, pode ser transformada em uma lousa eletrônica, transferindo para um computador, em tempo real, as anotações no formato de arquivos.

O Mimio utiliza a tecnologia Stylus Tracking ${ }^{\mathrm{TM}}$, que trata-se de uma combinação de transmissores infravermelhos e de ultra-som, sendo a caneta e o apagador os transmissores. Essa tecnologia é mais barata e mais fácil de usar do que a tecnologia utilizada nas lousas eletrônicas. Os transmissores registram os movimentos de pilots comuns encaixados em uma cápsula em forma de caneta. Deste modo, tudo o que for escrito será imediatamente transferido para o computador, da forma como aparece na lousa branca podendo ser visualizado em tempo real.

O ambiente do software do Mimio consiste no aplicativo Mimio, plug-in MimioMouse $^{\mathrm{TM}}$ e alguns componentes opcionais como o Mimio boardCast.

\section{a) $\mathbf{O}$ aplicativo Mimio}

O aplicativo Mimio captura a informação contida na lousa branca. É este aplicativo que possibilita registrar, reproduzir, imprimir e compartilhar estas informações. A impressão do conteúdo da lousa pode ser feita, diretamente, pela barra de captura do Mimio ou pode usar o aplicativo para examinar informações registradas e armazenadas em um arquivo com extensão INK e imprimi-las em uma 
impressora conectada ao computador (Virtual Ink, 1999).

Uma sessão inteira da lousa é gravada em um mesmo arquivo INK, que pode ser enviado, por e-mail, para outros usuários do Mimio. Para que usuários, que não tenham esta tecnologia, também possam utilizar o arquivo, o aplicativo Mimio permite a exportação para outros formatos - como HTML, JPG, BMP, WMF (Windows Metafile Format) e EMF (Enhanced Windows Metafile) - permitindo, assim, sua utilização. No software do Mimio, o usuário pode selecionar uma anotação no quadro Mimio, arrastá-la e colocá-la em outros aplicativos do Windows, podendo assim, compartilhar essas informações. A figura 2 mostra o aplicativo Mimio em português, versão 2.1, que exibe, à direita, as “lousas capturadas”.

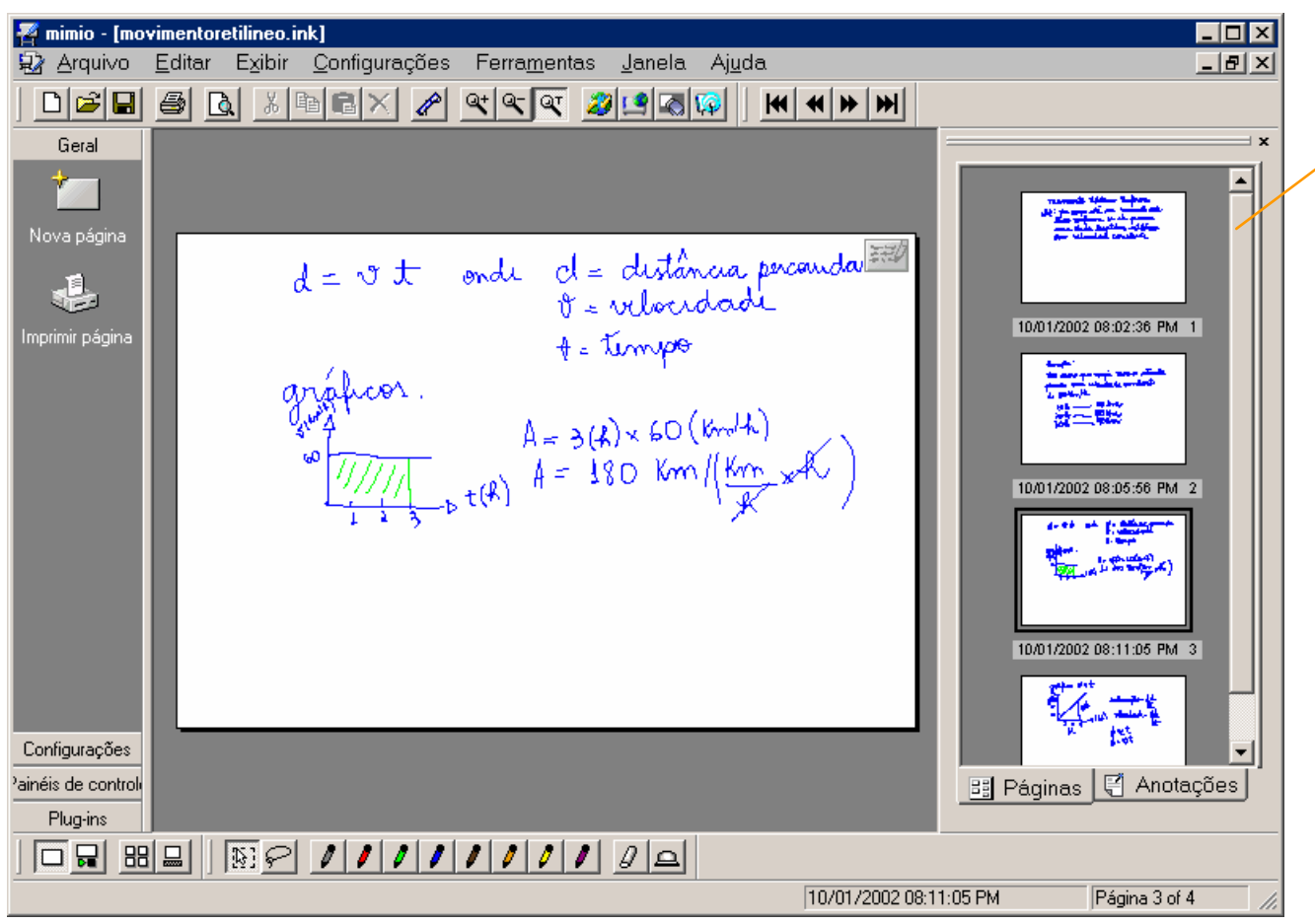

Figura 2 - Tela do aplicativo Mimio versão 2.1.

\section{b) O plug-in MimioMouse}

O plug-in MimioMouse permite trabalhar com a barra de captura, um projetor multimídia conectado ao computador e com uma caneta especial para uso com o MimioMouse, simulando as funções de um mouse e transformando a lousa branca em uma área de trabalho do Windows. O controle das operações de qualquer aplicativo é feito diretamente na tela que está sendo projetada em sala de aula. Para usar o MimioMouse, basta conectar o projetor ao computador e iniciar a projeção, acionando o plug-in 
MimioMouse no aplicativo do Mimio.

\section{c) $\mathrm{O}$ Mimio boardCast}

O Mimio boardCast é uma ferramenta de criação de conteúdo para a Internet utilizando a plataforma RealSystem ${ }^{\mathrm{TM}}$ G2 da RealNetworks, Inc. A RealNetworks permite a transmissão de conteúdo multimídia pela Internet, usando tecnologia streaming para fornecer apresentações ao vivo ou on-demand. O boardCast sincroniza as informações escritas na lousa branca, onde está fixado o Mimio, com a stream de áudio, gravando os arquivos no computador do usuário ou transmitindo-os pela Internet.

A sincronização do conteúdo da lousa com o áudio foi desenvolvida para os princípios de EAD, por isso requer baixa largura de banda (Virtual Ink Corp., 2000). Para reproduzir e assistir esta aula, que pode ser chamada de "aula virtual”, o aluno precisa instalar no seu computador uma versão do RealPlayer, adquirida no site www.real.com. A figura 3 mostra a tela inicial do Mimio boardCast.

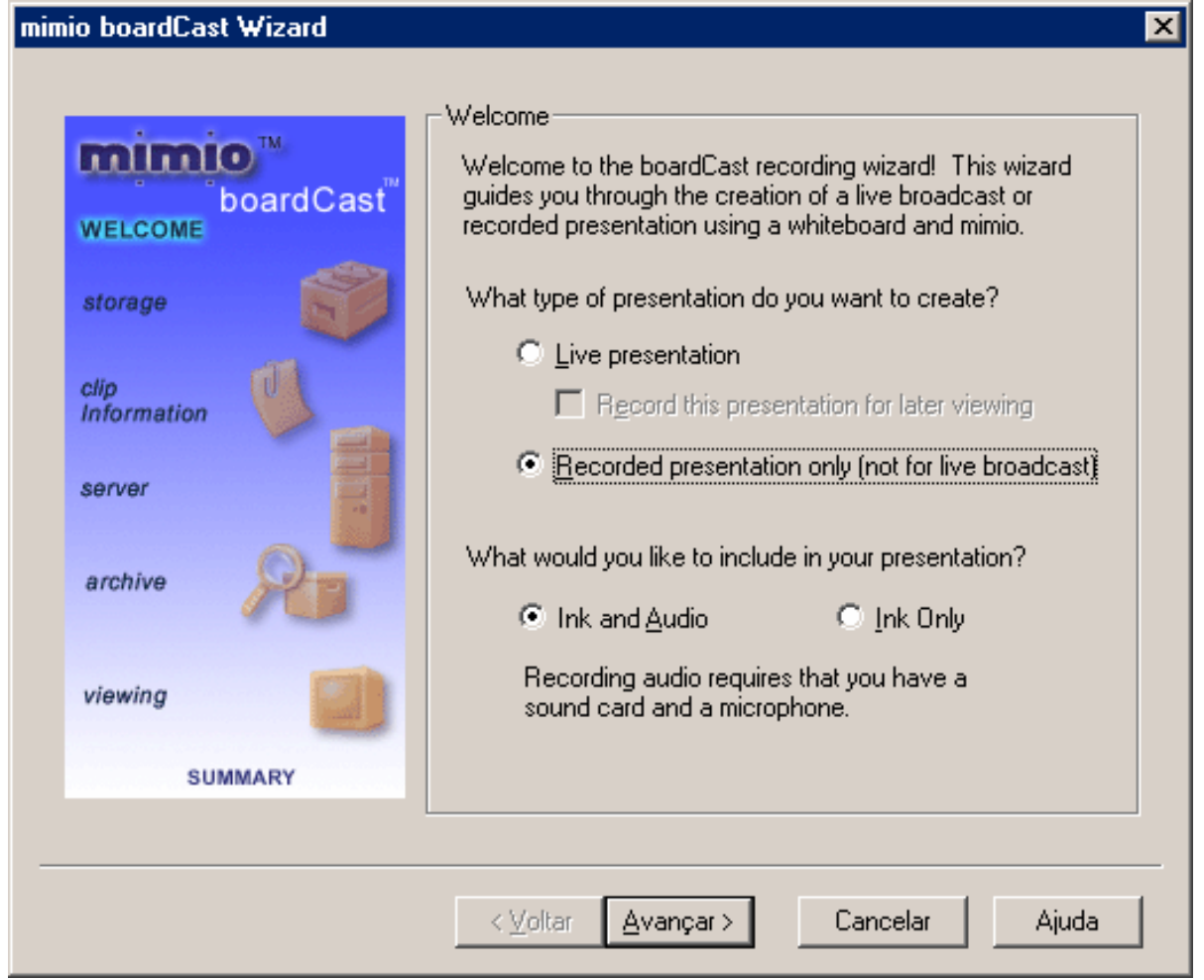

Figura 3 - Tela inicial do Mimio boardCast.

\section{Referências do Apêndice I}

Site do Mimio. Disponível em: <http://www.mimio.com>. 
VIRTUAL INK. Noções Básicas sobre seu Mimio. (Manual do equipamento Mimio). Boston, 1999.

VIRTUAL INK CORP. T.H.E. Journal, v.28, n.2, September 2000. 


\section{Apêndice II}

\section{A Linguagem SMIL}

A linguagem SMIL (Synchronized Multimedia Integration Language) Linguagem de Integração de Multimídia Sincronizada - é uma especificação do World Wide Web Consortium (W3C), desenvolvida em 1998, para criar uma maneira de enviar streams interativas e contextualizadas de multimídia pela Internet (W3C, 2003). Ainda é uma linguagem pouco explorada, mas vem ganhando o seu espaço na Internet, possibilitando a sincronização de recursos multimídia.

SMIL é parecida com a linguagem HTML e utiliza a tecnologia streaming, que envia os arquivos, aos poucos, para o cliente, dando a sensação de continuidade, sem exigir que o usuário faça um download prévio do arquivo inteiro. SMIL não é uma animação propriamente dita, é uma linguagem de integração, pois permite que diferentes objetos multimídia, tais como: áudio, animação em Flash, imagens, vídeo, texto, sejam coordenados simultaneamente na tela. De acordo com o W3C, uma apresentação SMIL tem as seguintes características (W3C, 1999):

- possui vários componentes, os quais são acessíveis via URLs (Uniform Resouce Locator), como por exemplo, arquivos armazenados em um servidor Web;

- os componentes têm diferentes tipos de mídia, como áudio, vídeo, imagem ou texto;

- há controle da apresentação por parte do usuário;

- a apresentação pode ser iniciada de qualquer ponto;

- o usuário pode selecionar os links existentes na apresentação.

\section{Aspectos Históricos}

Antes da linguagem SMIL, o envio de som e imagens dinâmicas ou 
estáticas pela Web, era feito com cada elemento separado dos outros e a coordenação com os demais era realizada por meio de programação. Não se podia controlar o início ou o final do vídeo e o usuário precisava “clicar” em um link, na página, para abrir o vídeo, seja através do RealPlayer ou do integrado na página.

Com a linguagem SMIL, pode-se coordenar o tempo dos objetos de mídia enviados, onde cada objeto é acessado com um único URL, o que viabiliza apresentações de objetos vindo de lugares distintos, além de facilitar a utilização destes objetos em múltiplas apresentações.

Em 1995, no Workshop do W3C sobre "Real Time Multimedia and the Web", foi enunciado o conceito de uma integração de serviços em tempo real. Segundo Hoschka (1997), nessa época discutia-se também a necessidade real dessa integração, concluindo-se que seria importante adotar um formato declarativo simples como a linguagem HTML - para expressar sincronização de mídias na Web como uma alternativa e um complemento às linguagens de script. Pois a sincronização de mídias na Web, até então, poderia ser feita utilizando linguagens de script, como JavaScript ou Visual Basic, contrastando com os formatos declarativos. Estava surgindo a idéia da linguagem SMIL.

\section{Aspectos Operacionais}

SMIL é baseada em XML (Extensible Markup Language) e é similar à HTML, o que a torna de fácil leitura e compreensão. SMIL é case-sensitive, onde todas as tags devem ser escritas em minúsculas, exemplo: <smil>.

Uma opção muito utilizada é dividir o código em arquivos, permitindo sua organização e facilitando a resolução de possíveis problemas. São eles: RealText (*.rt) - contém a definição do texto; RealPicture (*.rp) - contém a definição das imagens e o próprio SMIL (*.smi) - faz a sincronização “chamando” os arquivos anteriores. Estes arquivos podem ser abertos, visualizados e editados em qualquer editor de texto, facilitando a compreensão da linguagem SMIL e ajudando na elaboração de uma apresentação.

\section{Estrutura da Linguagem}

Um documento SMIL pode ser apresentado como mostra a figura 5. Tudo o que é relacionado ao layout, incluindo a largura e a altura da janela, está entre as tags $<$ layout $>$ e $<$ /layout $>$ no cabeçalho do documento SMIL $(<$ head $>$.. $</$ head $>)$, 
conforme destaque.

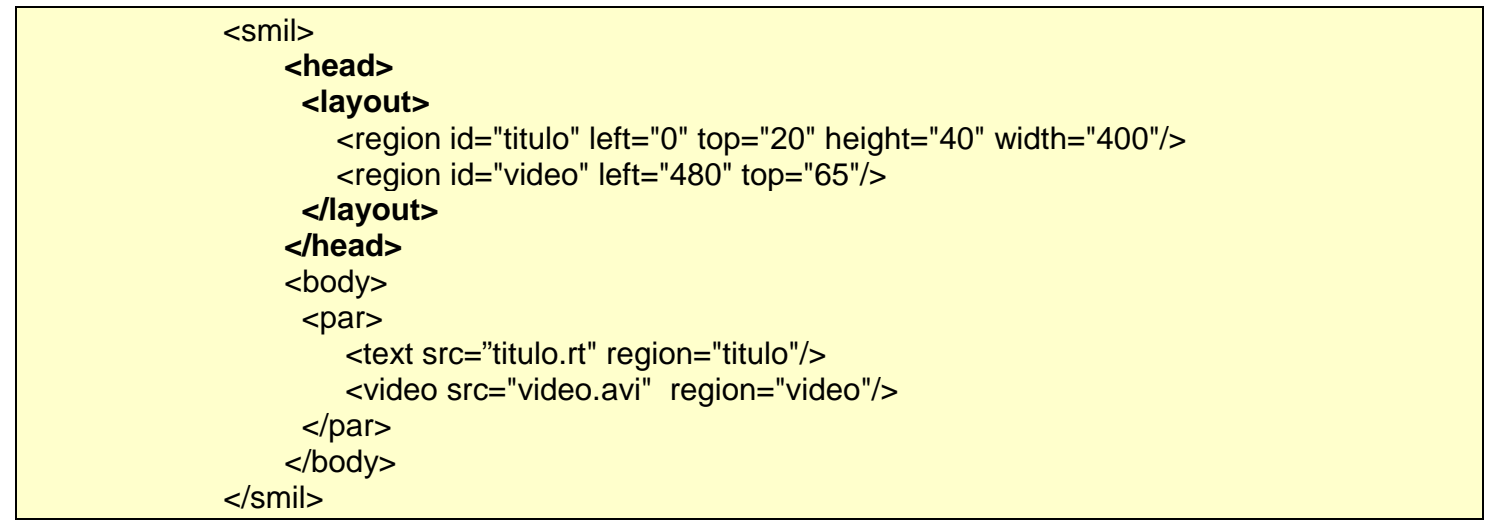

Figura 5 - Exemplo de um documento SMIL.

Há duas maneiras de se posicionar um objeto de mídia dentro de uma janela: pelo posicionamento absoluto, indicando a posição do objeto em pixels, ou pelo posicionamento relativo, em porcentagem da tela, conforme está apresentado, respectivamente, em destaque na figura 6.

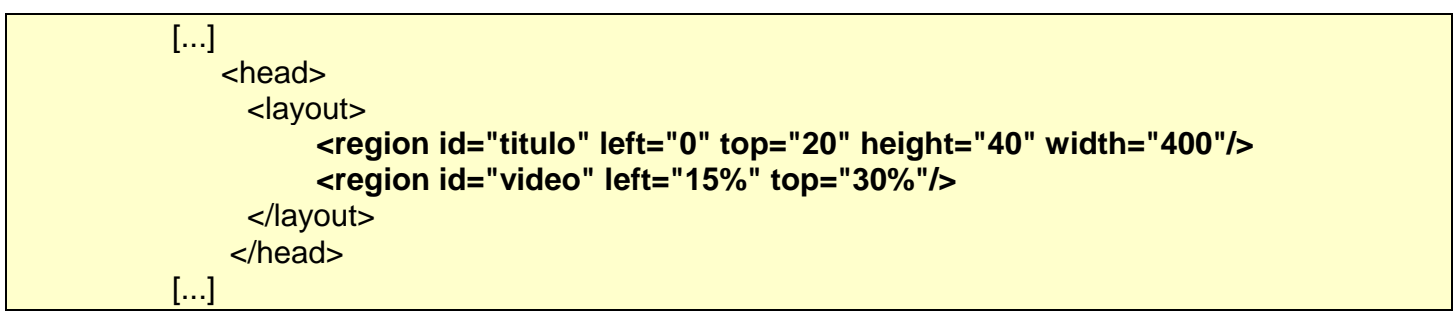

Figura 6 - Documento SMIL com destaque para o posicionamento de objetos de mídia.

Após o posicionamento dos objetos de mídia, é preciso definir a sincronização através de timeline (linha de tempo para os objetos de mídias). A linguagem SMIL permite a criação de timeline por meio de tags, como <seq> (define a execução seqüencial das mídias de uma apresentação) e <par> (define a execução em paralelo das mídias de uma apresentação). A timeline se localiza no corpo do documento SMIL entre as tags <body $>$ e </body>. Há diferentes maneiras para a criação de timeline em SMIL; um exemplo é definido na figura 7.

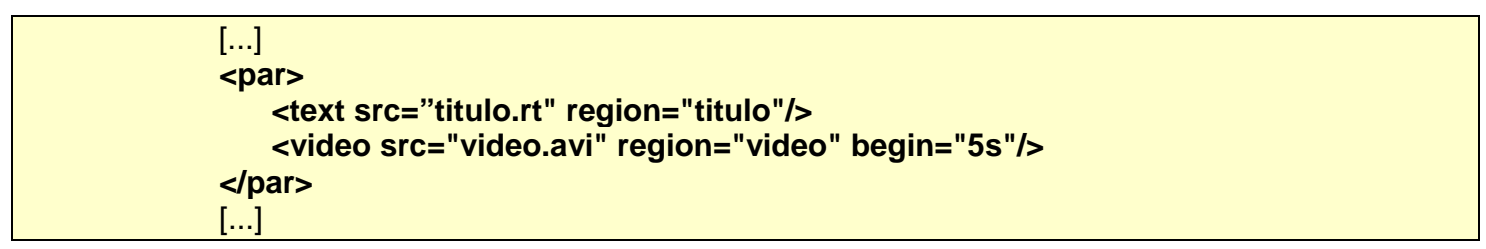

Figura 7 - Exemplo de uma timeline em SMIL. 
Neste exemplo de criação de uma timeline, foi usado um delay de 5 segundos para o objeto "vídeo", entre as tags <par> e </par>, sendo que o objeto “título" será iniciado desde o começo da apresentação até o seu término, enquanto que o objeto “vídeo” será iniciado após 5 segundos da apresentação ter começado. Os dois objetos serão executados em paralelo, devido a tag <par> (figura 8). Para serem executados em seqüência, os mesmos objetos devem ser inseridos entre as tags $<$ seq $>$ e $<$ /seq $>$ (figura 9 ).

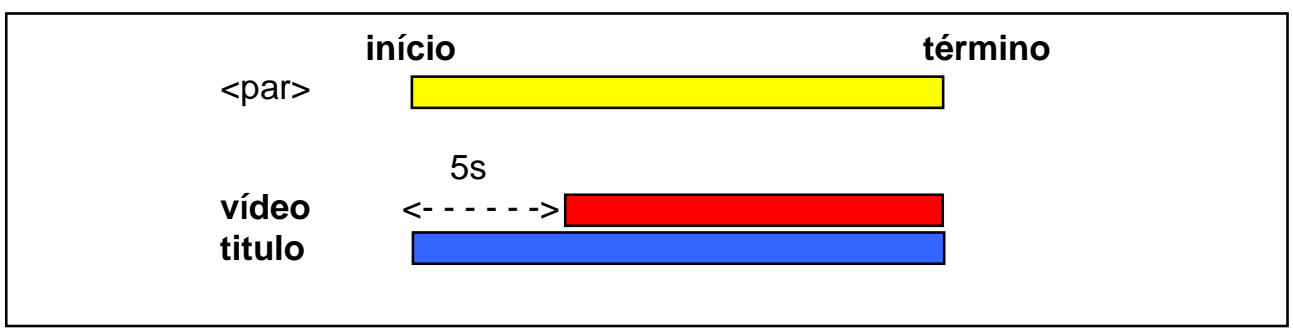

Figura 8 - Execução em paralelo das mídias de uma apresentação.

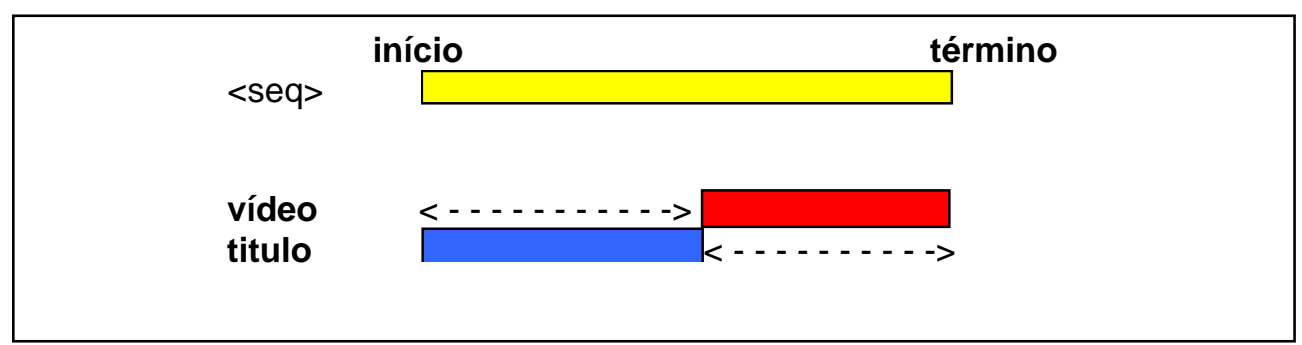

Figura 9 - Execução sequencial das mídias de uma apresentação.

\section{Referências do Apêndice II}

HOSCHKA, P. Toward Synchronized Multimedia on the Web. World Wide Web Journal, v.2, n.2, p.47-51, Spring 1997.

W3C (World Wide Web Consortium). Disponível em: <http://www.w3.org>. Acesso em: 2003.

W3C - Synchronized Multimedia Activity Statement. 1999. Disponível em: <http://www.w3.org/AudioVideo/Activity.html>- Acesso em: 2003. 